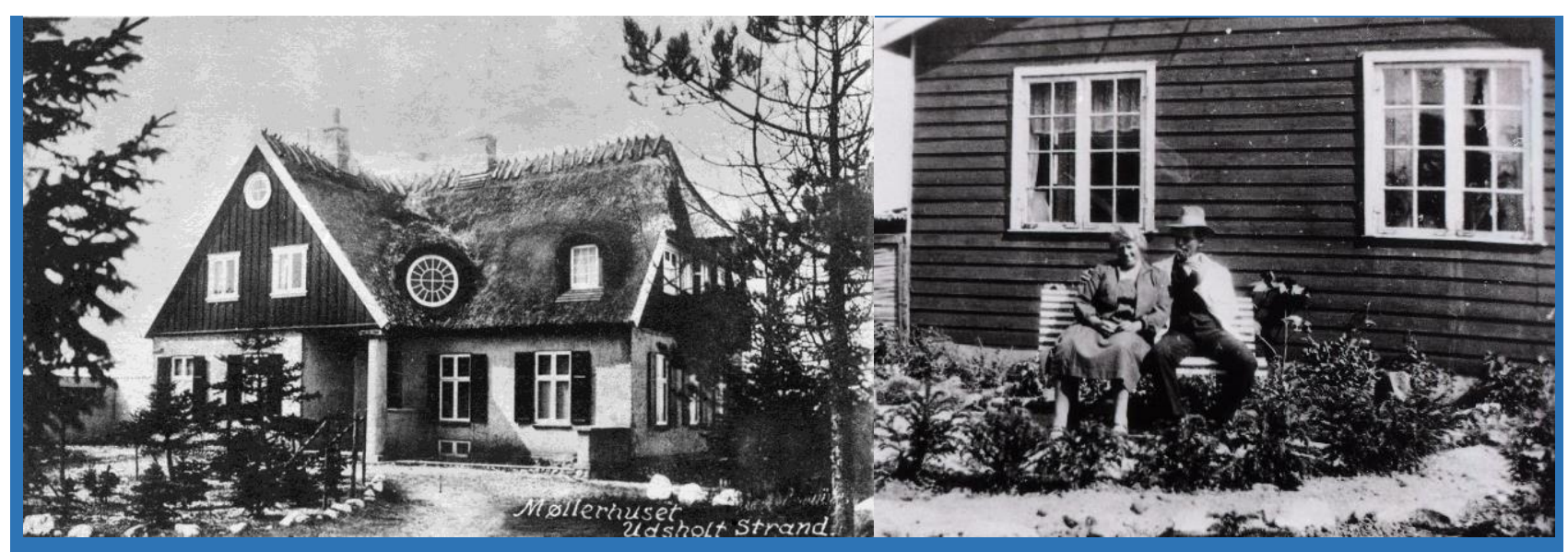

Henning Bro

\title{
Sommerhusbyen
}

Sommerhusbyer i mellem- og efterkrigstidens hovedstadsmetropol

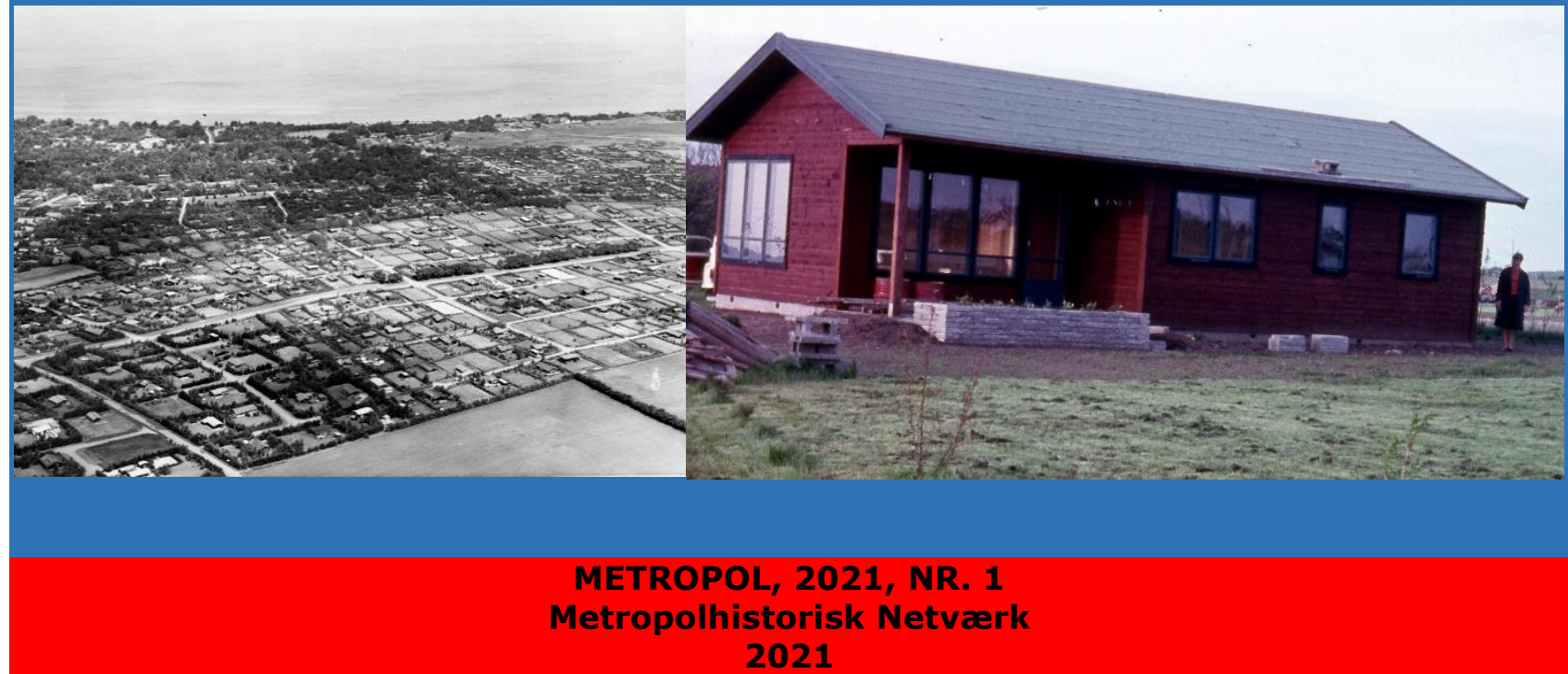




\section{DEL III}

Sommerhusbyernes storhedstid: Første efterkrigstid 


\section{Nye forudsætninger}

Mens hovedstadsmetropolens åbne land ved midten af det 20. århundrede rummede knapt 5.000 sommerhuse fordelt på to sommerhusbybælter, henholdsvis ved Kattegatkysten og Køge Bugt, tre større sommerhusbyer og spredtliggende meget små sommerhusbebyggelser, rejstes i den første efterkrigstid, mellem 1950 og 1973, ikke mindre end 33.000 sommerhuse fordelt på 72 sommerhusbyer helt overvejende ved metropolens kyst-, fjord- og søbredder.

Den første efterkrigstid repræsenterede dermed et sommerhusboom uden sidestykke i hovedstadsmetropolens ydre åbne opland, men det blev blot et af periodens vækstfænomener. Forsat industrialisering, yderligere økonomisk vækst, forstærket urbanisering og velfærdstatsudbygning blev nogle af de nøglebegreberne, der kom til kentegne de mest centrale træk ved den første efterkrigstid.

Samfundsmæssige faktorer, der i også i hovedstademetropolen muliggjorde en voldsom erhverv-, bebyggelses- og befolkningsmæssig vækst. Men også her generede den stigende realløn, der blev forudsætningen for, at bredere samfundslag fik mulighed for at fă eget hus med have, en moderne almennyttig bolig i de hastligt voksende forstæder og egen bil og med den samtidig øgede arbejdsfri tid at komme bort fra arbejds- og storbylivet ved at tage på charter-, camping- eller hytteferie eller at rykke ud til sommerhusbyer langt ude i den hastligt voksende hovedstadsmetropols yderområder.

\section{Den store hovedstadsmetropol}

Op igennem de første efterkrigsårtier udbyggedes hovedstadsmetropolen i et sådant omfang, at den i 1970 nåede et samlet folketal på over 1,7 mio., svarende til 35 procent af landets befolkning og omfattede selve hovedstaden og Københavns, Frederiksborg og Roskilde amtskommuner. Et resultat af en hidtil uset urban vækst

\section{Urbaniseringens omfang og karakter}

Væksten blev kendetegnet af meget omfattende forstadsdannelser. Først i form af en udbygning af de forstæder, der var opstået frem til midten af århundredet, hvorved der dannedes et 5-15 km bredt koncentrisk forstadsbælte uden om hovedstaden fra $\emptyset$ resundkysten i nordøst til Køge Bugt i sydvest. Selv om forstadsudbygning i den første tid således fandt sted inden for hovedstadsmetropolens fjerde bylag, brød forstadstilvækstens arealkrav til nyt industri-og boligbyggeri allerede i 50 'erne med det koncentriske urbaniseringsforløb. Herved fik de nye forstadsdannelser karakter af stadig mere langstrakte radiale bybånd, der, adskilt fra hinanden af stadigt bredere grønne og rekreative kiler, $\mathrm{i}$ længder af 30-40 km efterhånden kom til at flyde sammen købstæderne i den omliggende købstadsring, uden for hvilken der ved massive udvidelser af ældre stations- og landsbyer samtidig dannedes pendlersatellitbyer.

Som følge af betydelige ubebyggede arealer og dermed lavere grundværdier blev først forstæderne i Gladsaxe og Tårnby kommuner og siden dem på Nordvest- og Vestegnen samt i Køge Bugt-området i det 20. århundredes sidste halvdel kendetegnet af såvel arealkrævende nyetableret og tilflyttet eksportorienteret, landsdækkende og mere regionalt orienteret industri som store områder med mindre parcel- og rækkehuse og almennyttig boligbebyggelse fortrinsvis for arbejdere og lavere funktionærer. Herved forstærkedes den sociale opdeling, som hovedstadsmetropolens forstadsområde havde fået i midten af århundredet, idet særlig nordforstæderne fik karakter af boligbyer for højere indkomstlag kendetegnet af vidtstrakte naturområder og overvejende privat byggeri af villaer på store grundarealer. 


\section{Byøkonomisk teori og empir}

Som celledelingen i den organiske decentraliseringsteori, jf. Indledningens Kapitel 3, bliver kapitalens

industriinvesteringer, i overensstemmelse med teorien om den agglomererede byøkonomi, jf. Indledningens Kapitel

3, med hovedstadens, centralbyens/centrets, udfyldning og fortætning og de ulemper, der dermed opstår her, $\mathrm{i}$ efterkrigstiden placeret der, hvor fordelene nu er størst: De resterende friarealer i de ældre koncentriske forstæder og hovedparten af de nye radiale forstæder, som efter satellitbyteoriens efterfølgende fase, jf. Indledningens Kapitel 3, opsuger en del af hovedstadens befolkning og får en stor større koncentration af

fremstillingsvirksomheder. En mindre del af forstæderne, og navnlig de ældre, hvor de høje jordpriserne ikke er tillokkende for industriinvesteringer, fortsætter derimod i større eller mindre grad som boligbyer for arbejdskraft, der beskæftiges i både industritunge forstæder og hovedstaden, centret, hvor kapitalen i stigende grad ser fordele ved at udvide de servicemæssige og administrative investeringer. Centret, som angivet i den organiske decentraliseringsteori, afindustrialiseres og affolkes i et betydeligt omfang og konverteres til i stadig større omfang til at varetage de servicemæssige og administrative funktioner, som centralbyen, som centret, i

hovedstadsmetropolen hidtil tillige har vataget: Aktiviteter, der forsat er rammesættende for investeringer, vareproduktion, arbejdskraftsanvendelse og privat og offentlig service, ikke blot i hovedstadsmetropolens periferi af forstæder, men også på landsplan.

Op gennem efterkrigstiden udvides interaktionen i hovedstadsmetropolen efterhånden til også at omfatte byenheder i dens ydere dele, der, som bolig- og industribyenheder kommer til at indgå i et periferirelation i forhold til både hovedstaden og den indre del af metropolen. Disse ydre deles stations- og landsbyer får karakter af pendlersatellitbyer, der med overvejende boligbebyggelser leverer arbejdskraft til de indre dele af hovedstadsmetropolen eller til områdets købstæderne i købstadsringen. Disse forbliver ganske vist lokale oplandsbyer, men orienteres samtidig i stadig større grad mod den øvrige del af hovedstadsmetropolen. Dels om leverandør af arbejdskraft til denne, dels som industrilokaliseringsområder, idet kapitalen, efter teorien om den agglomererede byøkonomi, efterhånden ser større fordele ved at lokalisere industriinvesteringerne hertil, hvor grundpriser og arbejdsløn er lavere end i de mere centrale dele af byregionen.

Med den massive forstadsdannelse og byvæksten i den omliggende købstadsring og dennes omliggende satellitbyer, fulgte omfattende befolknings- og erhvervsmæssige forskydninger, der førte til en signifikant forandring $\mathrm{i}$ interaktionen imellem bydannelserne $\mathrm{i}$ hovedstadsmetropolens periferi og mellem disse og byregionens center, selve hovedstaden. Mens nogle forstæder overvejende forblev boligforstæder, og dermed i forhold til hovedstaden kom til at indgå i den centrum-periferirelation, som herskede før 1950, blev de nordvestlige og sydvestlige forstadsområder, ud over funktionen som boligbyer, hovedstadsmetropolens tyngdepunkt for produktions-, lager- og transportvirksomhed, hvortil der tillige pendledes fra boligforstæder og satellitbyerne.

I modsætning hertil blev hovedstaden i perioden kendetegnet af en stadig større afvandring og afindustrialisering. Mens folketallet i forstæderne, købstæderne og pendlersatellitbyer $i$ Københavns, Frederiksborg og Roskilde amtskommuner næsten fordobledes mellem 1950 og 1970, faldt det i samme periode med 12 procent i hovedstaden. Ud over et betydeligt fødselsoverskud og tilflytning fra provinsen, genereredes forstædernes befolkningstilvækst af en massiv udflytning fra hovedstaden, der allerede i midten af århundredet stort set var blevet udbygget og havde nået sit befolknings- og erhvervsmæssige mætningspunkt. Med byfortætningen var mulighederne for nyt industribyggeri og udvidelse af eksisterende fabriksanlæg i hovedstaden samtidig umuliggjort, mens forstæderne og de omliggende købstæder kunne tilbyde hovedstadsudflyttet eller nyetableret industri byggegrundene, der var billigere, og som havde en tilstrækkelig størrelse til den moderne industris mere pladskrævende produktionsbygninger og bedre tilkørselsforhold fra jernbane- og motorvejsnettet. I takt med afindustrialiseringen blev hovedstaden op gennem de første efterkrigsårtier i stadig højere grad erhvervsmæssigt kendetegnet af de styrende funktioner, der gennem privat og offentlig administrations- og servicevirksomhed udgik herfra, og som blev rammesættende for produktionsvirksomheder og offentlig service både regionalt og nationalt.

\section{Det urbane pres}

Med hovedstadsmetropolen massive urbanisering op gennem den første efterkrigstid og i realiteten foreløbige udbygning i den første del af 70 'erne, kom dens indre del til at udgøre et kolossalt, på nær grønne kiler og andre rekreative områder, sammenbygget urbant område, der udenfor omfattede godt nok mere spredt liggende, men alligevel meget betydelige 
byområder. I processen forsvandt naturområder, der hidtil havde haft en rekreative værdi eller havde potentiale for blive anvendt som så. Afstandene til de nærmest liggende rekreative områder blev dermed forlænget i betragtelig grad samtidig med, at disses mere yderlige placering i hovedstadsmetropolens fjerne opland gjorde tilgængeligeden til dem vanskeligere.
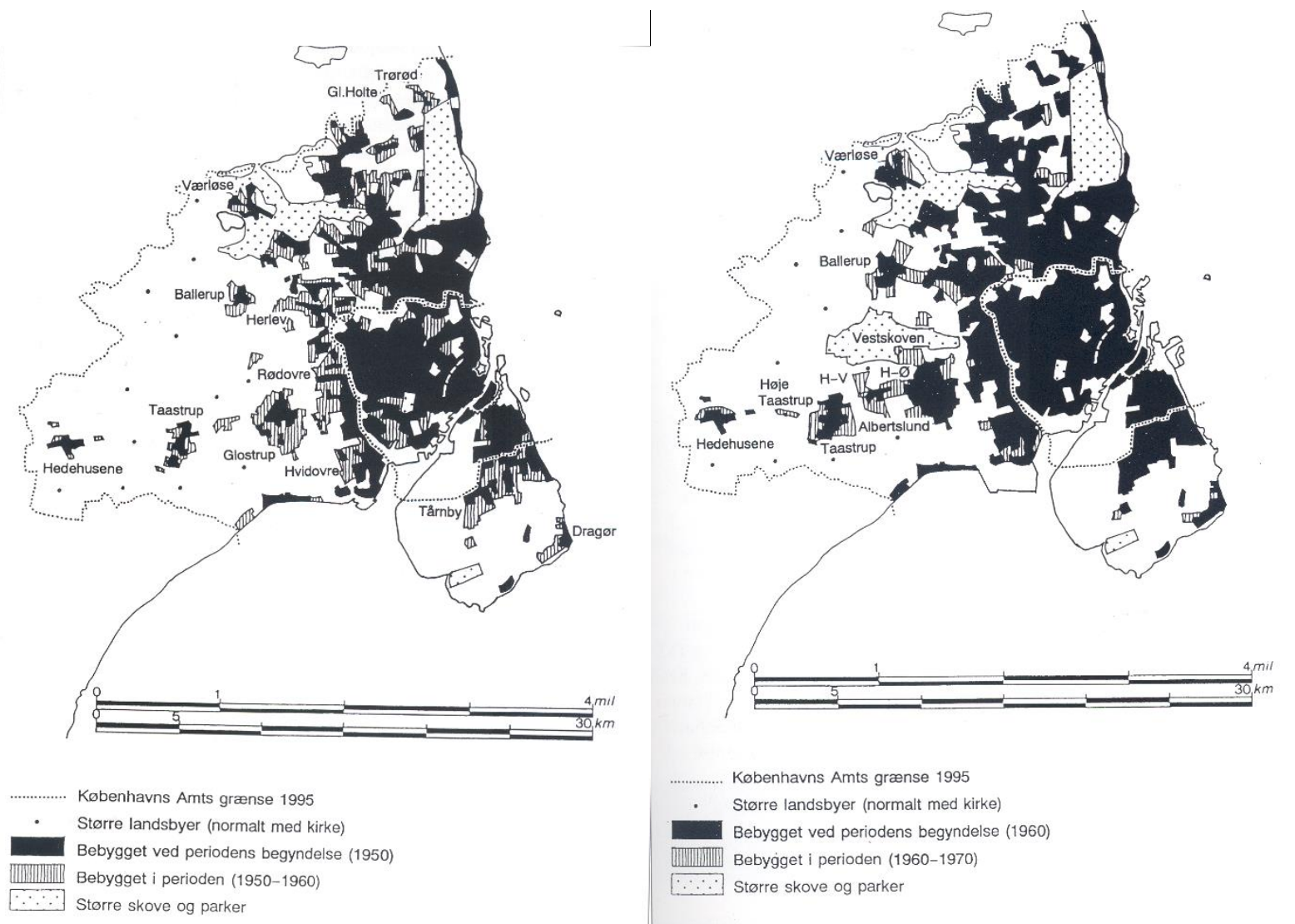

Bebyggelse i hovedstaden og Københavns Amtskommune 1950-1970. Til venstre: 1950-1960. Til højre: 1960-1970. (Kulturhistorisk oversigt, Københavns Amtskommune 1999)

Med denne urbaniseringsproces og dens negative sideeffekter forstærkedes modsætningen mellem arbejds- og dagligdagslivet i den yderlige fortættede hovedstadsmetropol med dens forcerede trafik, miljøbelastninger og stadig mere hektiske og monotome arbejdsliv på den ene side og på den anden frie og åbne omgivelser og et andet liv end bylivet. Et liv ved kyster, fjorde, søer eller blot i det åbne land, der alene kunne udleves i ferie- og fritiden og forudsatte, denne var til rådighed $\mathrm{i}$ et større omfang, men som under alle omstændigheder uanset tid og sted skulle være frisættende $\mathrm{i}$ forhold det urbane pres og dets arbejds- og familieliv. ${ }^{1}$

\section{Ferie- og fritid}

Med det udvidede arbejdsfri liv, som stadig større grupper af Iønmodtagere opnåede i den første efterkrigstid, åbnedes for hidtil ukendte ferie- og fritidslivsformer. Sommerhuslivsformen blev en af dem.

\section{Den arbejdsfri tid udvidelse}

Mens den almindelige lønmodtagers arbejdsuge og ferie i midten af det 20.århundrede stadig var på 48 timer, som fastlagt ved overenskomsten i 1919, og 2 uger, som følge af bestemmelserne i ferieloven fra 1938, blev den samlede arbejdstid i de følgende 40 àr nedsat så meget, at det svarede til en reduktion af arbejdsudbuddet på ca. 25 procent. Med den forstærkede industrialisering, teknologiens produktivitetsudvidelse, afvandringen fra landbruget og kvindernes stadig større andel af arbejdsstyrken, lykkedes det således fagbevægelsen, med den stigende organisationsgrad, i perioden først at øge reallønnen 
betragteligt og siden nogenlunde at fastholde den for brede grupper af Iønmodtagere samtidig med, at arbejdstiden nedsattes, og ferietiden forlængedes. I 1955 blev ferietiden udvidet til tre uger for senere at nå op på fire, og på samme tid fik arbejdstiden sit første dyk i 1958 for foreløbig at end på en 40-timers arbejdsuge. Med den kortere arbejdstid nedsattes den på ugens enkelte dage og særligt om lørdagen for i slutningen af 60 'erne at blive samlet på ugens fem dage, hvorved weekendfrihed blev en realitet.

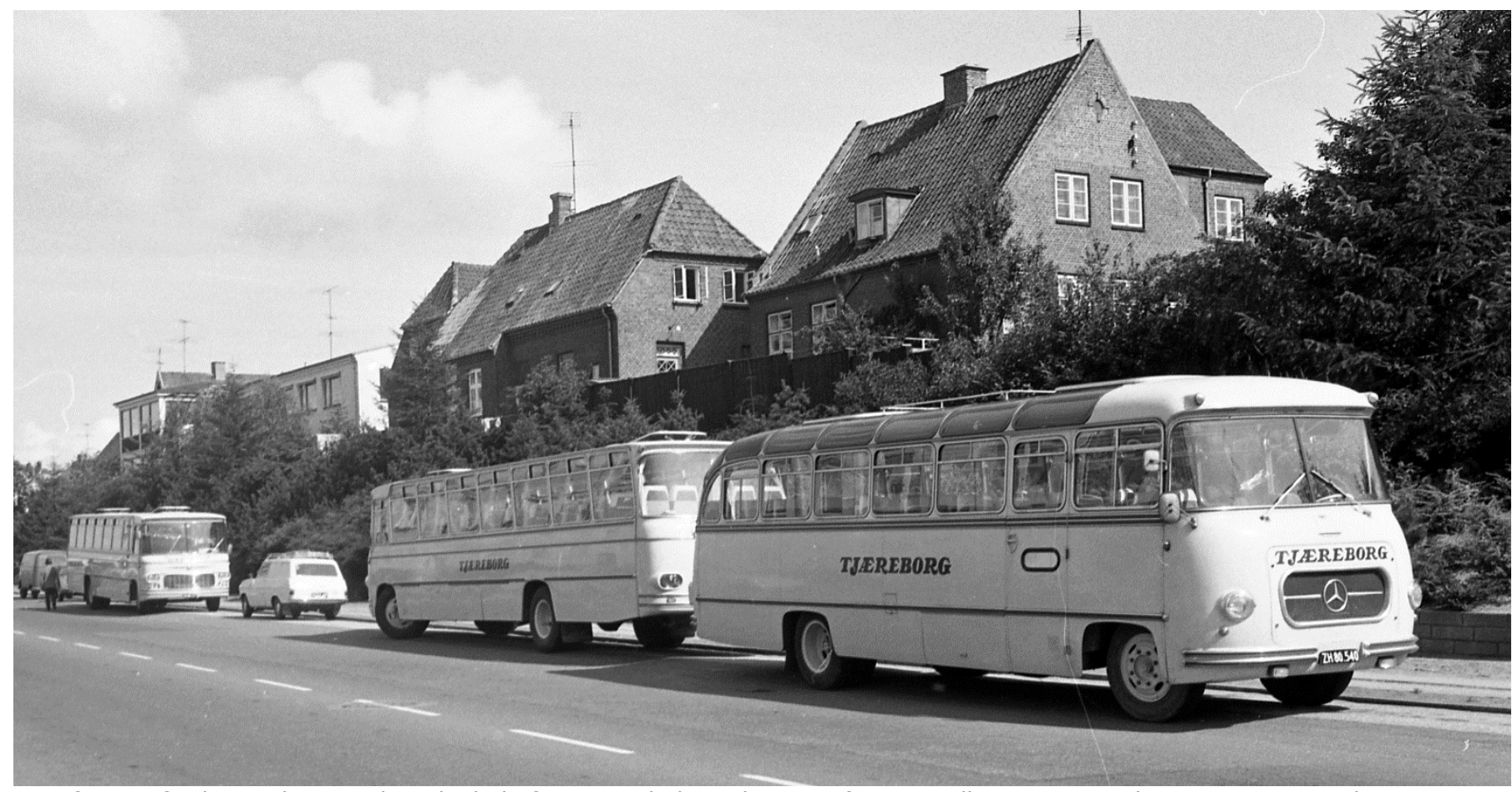

Den første efterkrigstids samtidig udvidede ferieperiode banede vejen for, at reallønsgevinsten kunne omsættes til charterrejser. Her venter tre busser fra Tjæreborg Rejser i sommeren 1966 på ringvejen i Fredericia på at køre ned til banegården og her at optage flere hold turister inden turen går syd på. (Lokalhistorisk Arkiv for Fredericia og Omegn)

\section{Fritidsforbrug}

Skønt det stærkt udvidede fritidsliv med øget fritid og realindkomst blev langt mere differentieret end i mellemkrigstiden, og i stigende omfang blev genstand for kommercielle interesser og dermed blev et forbrugsgode $\mathrm{i}$ form af et stort og forskelligartede aktivitetsudbud fra underholdnings-, ferie- og charterindustrien, fik udlevelsen af den frie tid gennem et friluftsliv i den første efterkrigstid samtidig en stadig større bredde, udbredelse og betydning og antog nye og mere mangeartede former. Selv om det med de stærkt stigende reallønninger for stadig bredere samfundslag og den udbyggede velfærdstats brede sociale sikring og økonomiske omfordeling blev muligt i et hidtil uset stort omfang at realisere en del af friluftslivet i eget enfamiliehuse, og dermed samtidig at opnå det værdisæt, der stadig knyttede sig til haveboligen, forstærkedes behovet for andre friluftsaktiviteter uanset om var husejer eller henvist til en lejlighed $i$ en etagebebyggelse.

Det være sig aktiv idræt eller blot afkobling i og nydelse af naturen i alt fra bynære parkanlæg til fjernere rekreative skov-, sø og- naturområder. Med privatbilen, der efterhånden blev hvermandseje, udvidedes den geografiske aktionsradius for friluftslivet til netop sådanne rekreative områder, som det offentlige samtidig tilvejebragte og som særligt de befolkningslag, der ikke økonomisk magtede fast ejendom, måtte henlægge friluftslivet til. Var der for disse grupper en smule mere økonomisk overskud, blev drømmen om eget hus eller sommerhus udlevet i den traditionelle kolonihave, den campingvogn, der erstattede teltet, eller i de almennyttige feriebyer, som senere udviklede sig til feriecentre med et stort udbud af forskelige former for aktiviteter. ${ }^{2}$ 


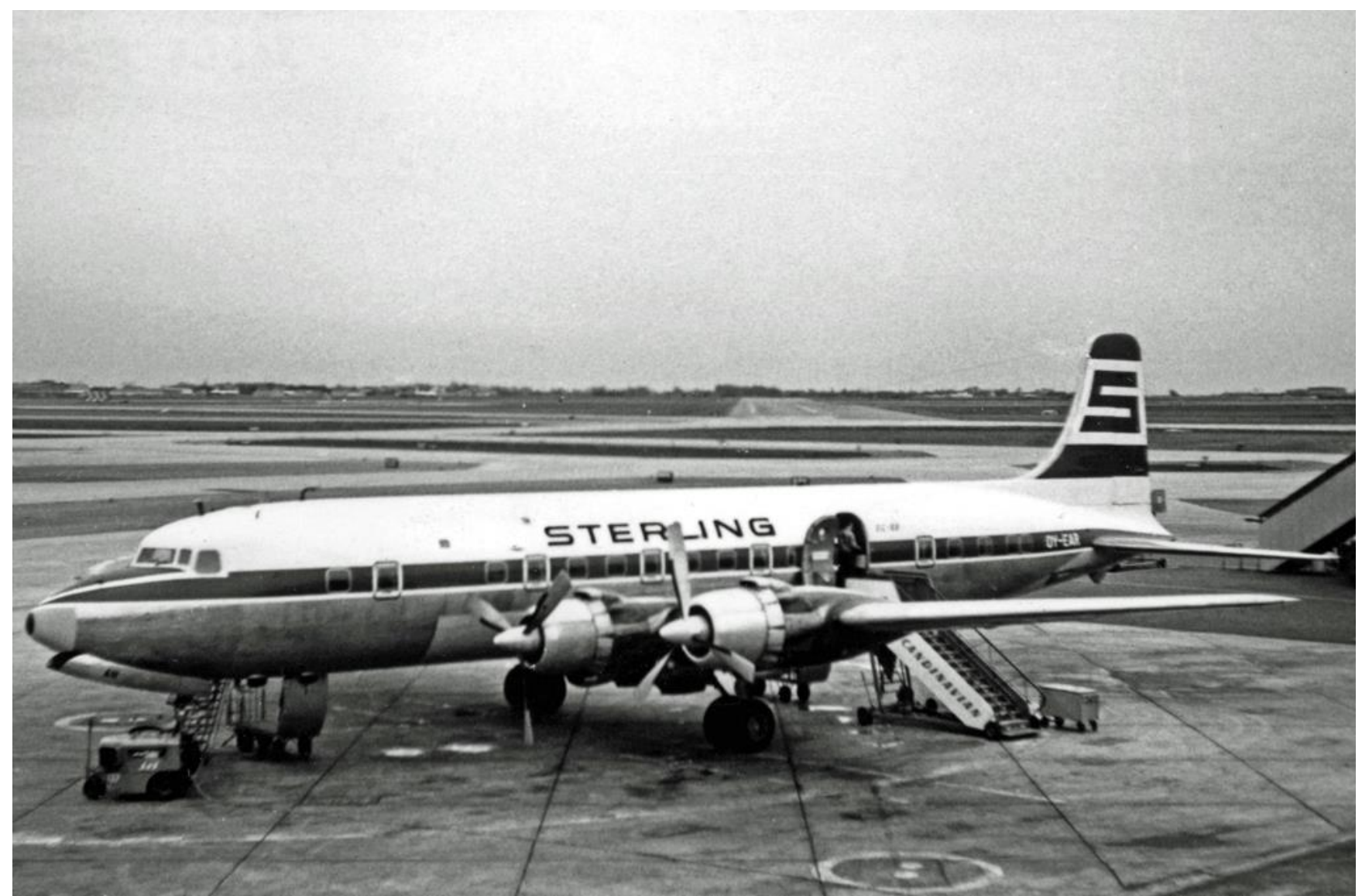

Med den flyteknologiske udvikling blev flyvemaskiner efterhånden så relativt billige, at de kunne anvendes til charterrejser for større befolkningsgrupper. Her er et fly fra Tjæreborg Rejsers flyselskab, Sterling Airways, i 1968 ved at være klar til afgang fra Københavns Lufthavn, Kastrup. (Frederiksberg Stadsarkiv)

\section{Sommerhuslivsformen}

For den del af hovedstadsmetropolens befolkning, der økonomisk magtede at erhverve et sommerhus, førte metropolens særligt stærke urbane pres til, at denne fritids- og feriebosætningsform som ramme for et friluftsliv blev langt mere eftertragtet end andre steder i landet (tabel III.1). Mens 1-5 procent af befolkningen i landdistrikter og mindre bymæssige bebyggelser og 9 procent i større byer ved udgangen af den første efterkrigstid benyttede den fritids- og ferieform, som sommerhuset gav mulighed for, var denne andel signifikant højere i hovedstadsmetropolen. Med 17 procent højest i den intensivt byggede hovedstad, hvor andelen af etageboliger udgjorde 92 procent af samtlige boliger, og med 11 noget mindre i hovedstadsmetrolens forstæder, der var mindre bebygget, og hvor der var lettere adgang til rekreative områder, og enfamiliehuse med 48 procent af samtlige boliger her muliggjorde den kompensation for metropolens urbane pres, som en havebolig udgjorde. ${ }^{3}$

Tabel III.1. Befolkningens ferieophold i eget sommerhus procentvis fordelt på bymæssighed, 1974

\begin{tabular}{|l|l|}
\hline Bymæssighed & Ferieophold i eget sommerhus \\
\hline Hovedstaden & 17 \\
\hline Hovedstadens forstæder & 11 \\
\hline Større byer & 9 \\
\hline Mindre byer & 5 \\
\hline Bymæssig bebyggelse & 4 \\
\hline Landdistrikter & 1 \\
\hline 4
\end{tabular}

Mens et sommerhus i fredelige, landlige og rekreative omgivelser i den første efterkrigstid således fortsat kompenserede for det levevilkårsunderskud, som bylivet og helårsboligen i den 
fortættede hovedstadsmetropol udgjorde, og stadig gav mulighed for opnåelse af den sociale status, som besiddelsen af en havebolig indbefattede, ændredes dets hidtidige brugsværdi. Med periodens stigende realindkomster og relativt billigere fødevarepriser kom dyrkningen af grønsager ikke som hidtil at til udgøre et nødvendigt supplement til husholdningsøkonomien. Da størsteparten af hovedstadsmetropolens befolkning i efterkrigstiden ikke som forældre- og bedsteforældregenerationerne havde veneration for et tidligere liv i provinsens landdistrikter, mistede denne form for havedyrkning samtidig sin funktion som erstatningsobjekt for en tabt rural livform.

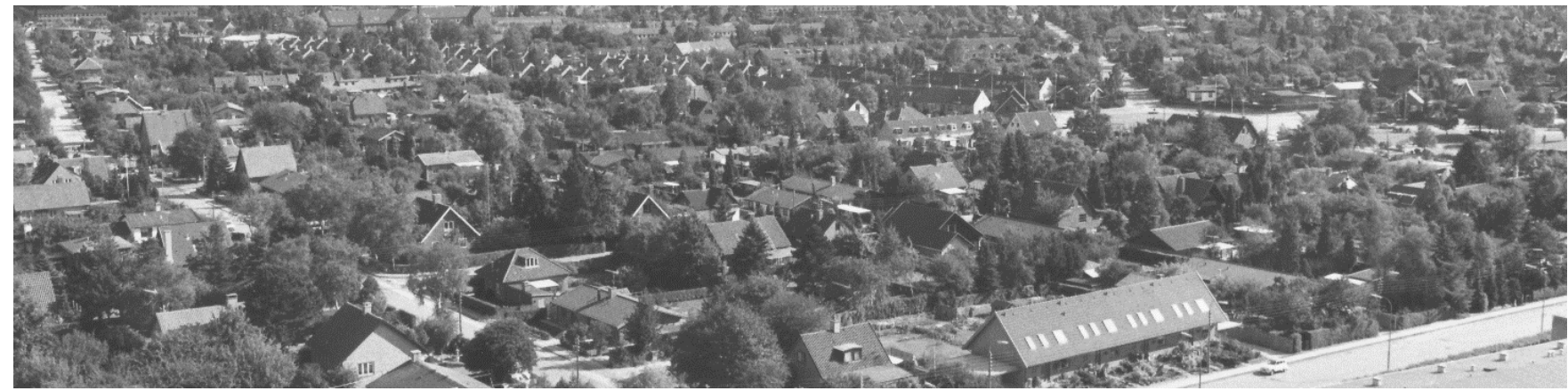

Med den første efterkrigstids stigende reallønninger kom en havebolig i form af et parcelhus $i$ en af hovedstadsmetropolens forstæder til at ligge inden for rækkevidde for stadig bredere samfundslag. Her et villakvarter $i$ Hvidovere skudt fra luften i 1986 (Forstadsmuseet)

Til gengæld blev sommerhuset med sin naturnærhed og mulighed for her at udleve en anden og mere rustik livsform en kompensation for både efterkrigstidens veludstyrede helårsboliger og det bymæssigt hektiske og stereotype arbejds- og familieliv. Et miljøskift i ferie- og fritiden, hvor genkendelige rutiner fra det hjemlige i et sommerhus kunne kombineres med følelsen af være langt væk hjemmefra og her at have "frihed" og tid til afslapning, mere samvær og naturoplevelser.

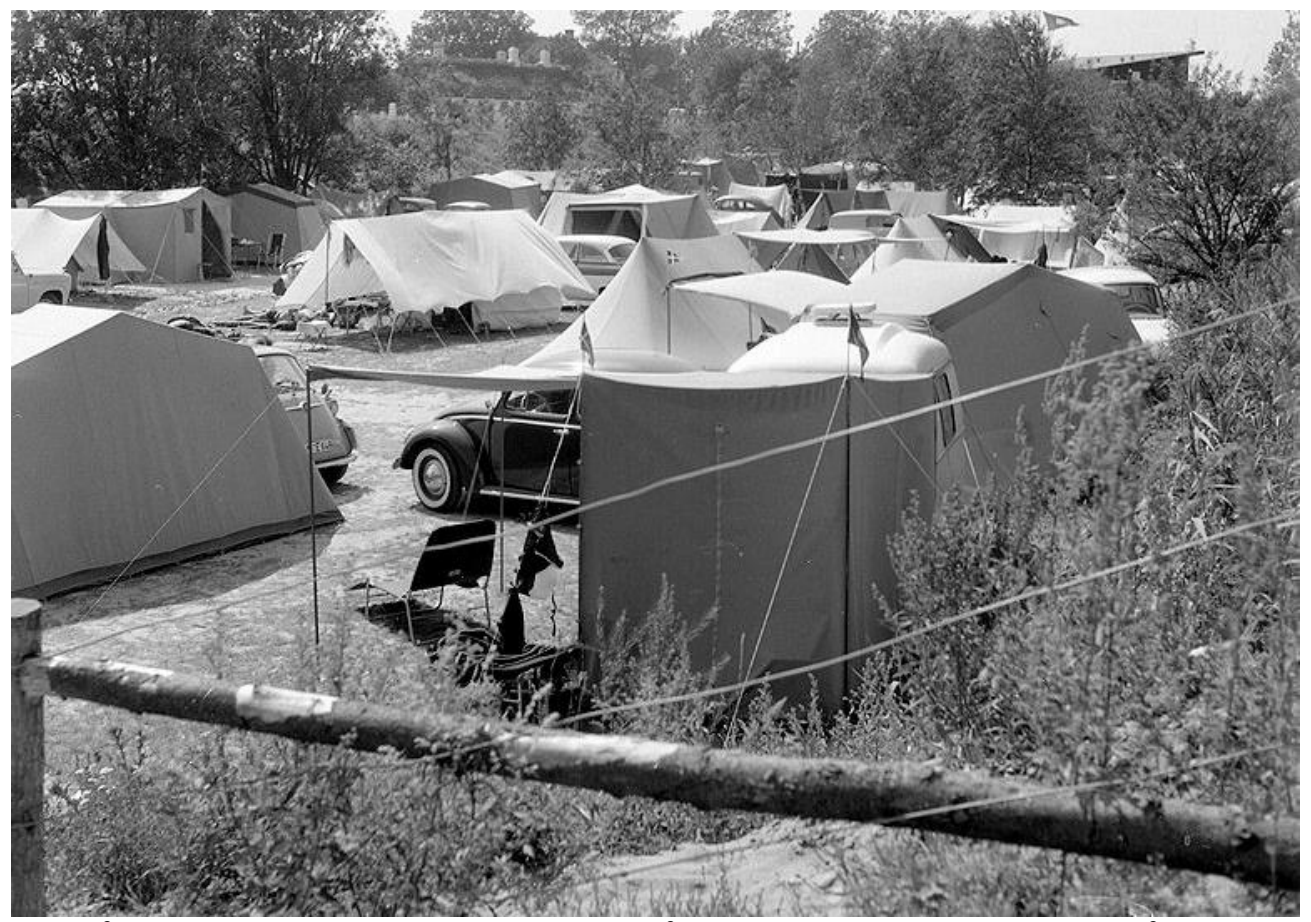

Friluftliv forblev også i den første efterkrigstid en udbredt måde at anvende ferie- og fritiden på. Med privatbilens brede udbredelse blev det muligt at rykke campinglivet længere ud i hovedstadsmetropolens abne land. F.eks. som her i 1960 til campingpladsen i Dronningmølle. (Gribskov Arkiv) 


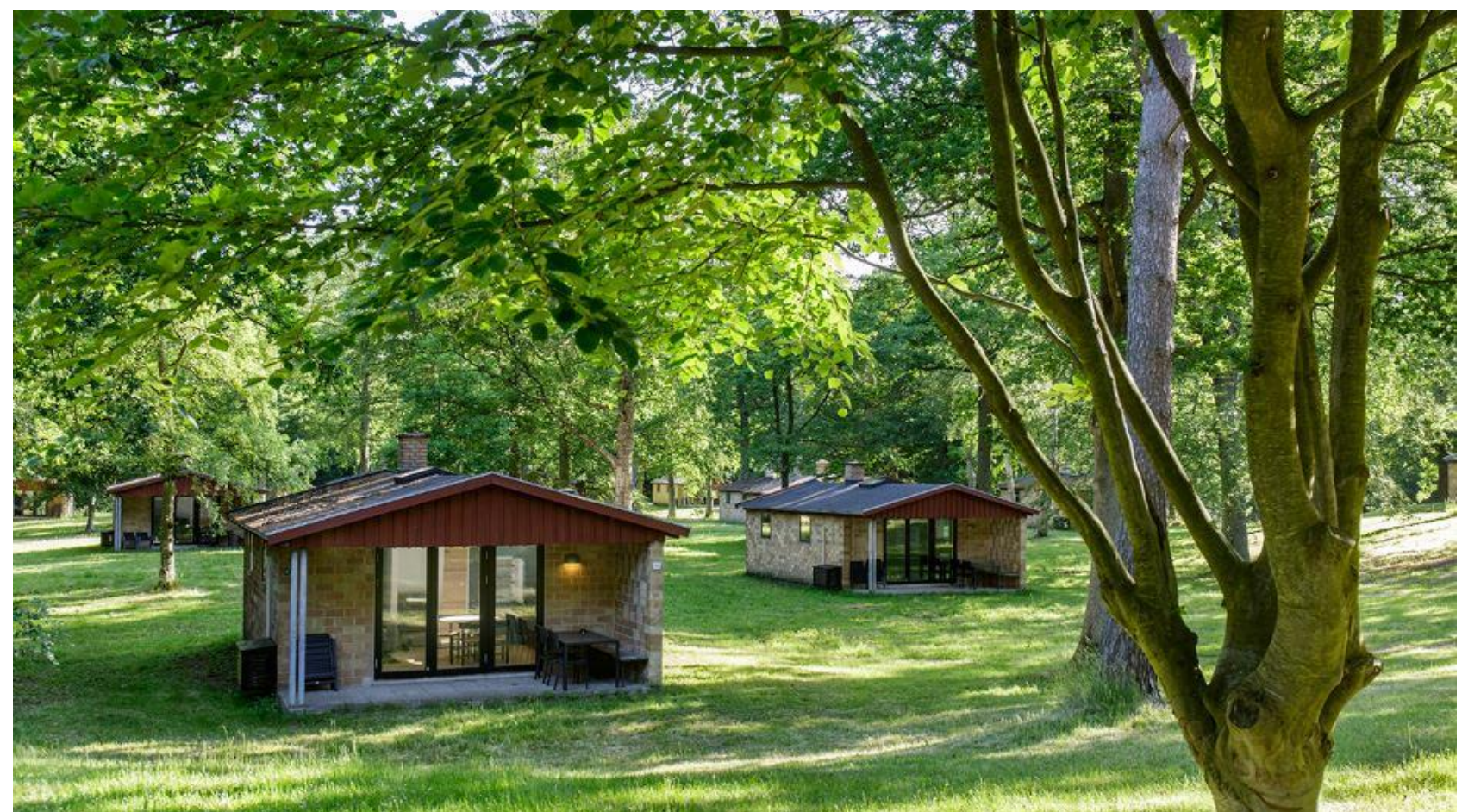

Ud over udvidelsen af paletten af ferietilbud oprettede Dansk Folkeferie i den første efterkrigstid flere feriebyer. Bl.a. her nord for Helsingør, hvor de laveste indkomstlag fik mulighed for ferie i skovrige omgivelser og med Kattegatudsigter, der ellers var reserveret til de mest privilegerede. (Foto 2015: Frederiksberg Stadsarkiv)

\section{Samfundsøkonomiske udviklingstræk}

Et gode for bredere samfundslag, der i den første efterkrigstid opnåedes ved et større økonomisk råderum, som kunne dække de udgifter, der knyttede sig til skatter, erhvervelse af elementære livfornødenheder og en helårsbolig, men som samtidig gav økonomiske ressourcer til have den sekundærbolig, som sommerhuset udgjorde.

Tabel III.2. Årlig vækst i procent af rådighedsbeløb og konsum i faste priser, mio. kr. 1950-1969.

\begin{tabular}{|l|l|l|}
\hline & Rådighedsbeløb & Konsum \\
\hline $1950-1959$ & 3,3 & 2,5 \\
\hline $1960-1969$ & 5,5 & 4,0 \\
\hline
\end{tabular}

Kilder. $^{5}$

Samfundsøkonomisk blev den første efterkrigstid således kendetegnet af: Dels en voldsom mekaniseringsproces i landbruget med afvandring fra og en massiv ejendomskoncentration i erhvervet til følge. Dels endnu en industrialiseringsbølge og vækst i de øvrige byerhverv. Stærkt forandrede økonomiske vilkår, der udgjorde forudsætningen for, at den først efterkrigstid blev den periode i det 20 . ărhundrede, hvor den økonomiske vækst og væksten i både rådighedsbeløbet og det samlede konsum blev størst (tabel III.2).

Den kraftige vækst i konsumet var udtryk for en massiv forøgelse af det private forbrug, der fulgte med den kraftige økonomiske vækst, som på ny generede betydelige forskydninger i sammensætningen af det samlede forbrug (tabel III.3). Den andel af det samlede forbrug, der anvendtes til basale livsfornødenheder, fødevare, fodtøj, beklædning, bolig, brændsel, skatter m.v. faldt således markant mellem 1939 og 1970, mens de øvrige forbrugsposter i samme periode opnåede betydelig større andele. Af disse opnåede andet konsum, luksusprægede ikke-varige forbrugsgoder, som bl.a. fornøjelse og udenlandsrejser, den største andel, hvilket dog i forhold til udgangspunktet i 1939, repræsenterede en mindre stigning end den, der gjorde sig gældende for varige forbrugsgoder, herunder sommerhuse. En forbrugspost, der i 1970 opnåede den andenstørste andel af de forbrugsenheder, der faldt uden for de basale livsfornødenheder. ${ }^{6}$ 
Tabel III.3. Forbrugssammensætningen i procent, 1939-1970

\begin{tabular}{|l|l|l|}
\hline & 1939 & 1970 \\
\hline Fødevarer & 32 & 21 \\
\hline Nydelsesmidler & 7 & 10 \\
\hline Fodtøj og beklædning & 15 & 7 \\
\hline Husleje og prioriteter & 12 & 9 \\
\hline Brændsel, el, gas og varme & 4 & 2 \\
\hline Egen transport & 2 & 7 \\
\hline Kollektivtransport og kommunikation & 4 & 4 \\
\hline Varige forbrugsgoder & 6 & 12 \\
\hline Andet konsum & 18 & 28 \\
\hline Total & 100 & 100 \\
\hline
\end{tabular}

Kilder. ${ }^{7}$ 
Kapitel 2

\section{De ekspanderende sommerhusbyer}

Med det sæt af samfundsmæssige forudsætninger, der generede et viritabel sommerhusboom i hovedstadsmetropoplen, blev sommerhusbyen i den første efterkrigstid her for alvor et bymæssigt fænomen i metropolens åbne opland. Her blev nye sommerhusbyer og kraftigt udvidede ældre sommerhusbyer et dominerende byelement sammen de mange pendlersatellitbyer, som større landsbyer og stationsbyer omdannedes til på samme tid.

En særegen og afledt urbaniseringsproces af det stadig større volumen og den stadig større udbredelse, hovedstadsmetropolen opnåede i perioden. Og dermed en følge af at en stadig større del af hovedstadsmetropolens befolkning søgte ud af de tætbebyggede

hovedstadsbydele, forstæder og omgivende købstæder i købstadsringen for uden for denne bymæssige ring her enten at erhverve et enfamiliehuse $i$ frie og rurale omgivelser til en mere rimelig pris eller at udleve et fritids- og friluftsliv i et sommerhus ved de kyst-, fjord- og søbredder, som indgik blandt nogle af attraktioner i metropolens åbne land.

\section{Sommerhusbyernes volumen}

Havde tilvæksten af nye sommerhuse været støt stigende op gennem mellemkrigstiden og kulmineret i 30 'erne, førte besættelsestidens krigskrise og den efterfølgende fredskrise til et betydeligt fald i nyopførte sommerhuse i 40 ' erne (figur III.1). Det blev derfor først med samfundsøkonomiens genopretning omkring 1950 og høje økonomiske vækstrater fra slutningen af $50^{\prime}$ erne og frem til starten af 70 'erne, at de økonomiske forudsætninger skabtes for den første efterkrigstids sommerhusboom.

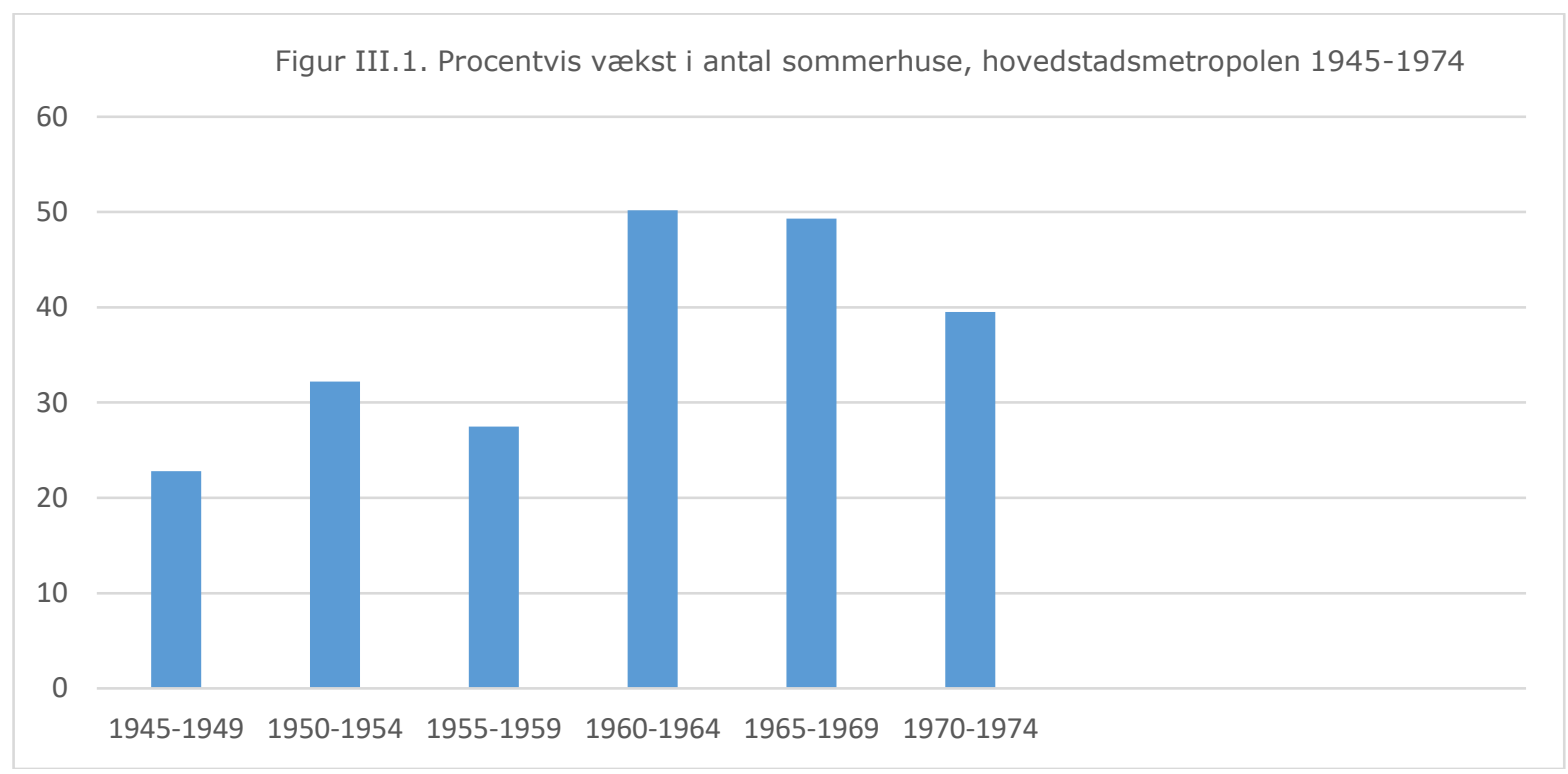

Kilde: APPENXIX VI.

Et kraftigt stigende og meget stort sommerhusbyggeri, der på 23 år tilvejebragte ikke mindre end 33.000 sommerhuse, svarende til 1.427 sommerhuse pr. år, øgede antallet af sommerhusbyer til 72 og gav disse et sådan volumen, at de kunne rumme det langt mindre antal sommerhuse, godt 7.000, der opførtes i den sidste efterkrigstid.

\section{Sommerhusbyernes lokalisering}

Mens sommerhusbybæltet langs Køge Bugt i den første efterkrigstid blev opsuget i det radiale forstadsbånd, der lagde sig ned langs bugten, udvidedes de 23 ældre sommerhusbyer ved den 
attraktive Kattegatkyst i sådan omfang, at det sammen med to nye sommerhusbyer i hele efterkrigstiden kom til at rumme mere en halvdelen periodens sommerhuse (tabel III.4). Da ejendomspriser lå særlig højt i Kattegatkysten sommerhusbybælte, og dette efterhånden opfyldtes med bebyggelse, blev den mindre halvdel af den første efterkrigstids sommerhuse lokaliseret til tre ældre og stærkt udvide sommerhusbyer og 46 nye overvejende ved andre kystnære områder i hovedstadsmetropolens ydre åbne land.

Tabel III.4. Procentvis fordeling af antal sommerhuse samt udstyknings- og bebyggelsesperioder i hovedstadsmetropolens sommerhusbyer, 1950-1990.

\begin{tabular}{|l|l|l|l|l|l|}
\hline \multirow{2}{*}{ Sommerhusbyer } & Procent andel af antal sommerhuse & \multirow{2}{*}{ Udstykningsperiode } & \multirow{2}{*}{ Bebyggelsesperiode } \\
\cline { 2 - 5 } & $1950-1973$ & $1974-1990$ & $1950-1990$ & & \\
\hline Kattegatkysten & 53,8 & 58,9 & 54,8 & $(1949)-1979$ & $1950-1989$ \\
\hline Roskilde Fjords $\varnothing$ stside & 12,7 & 9,1 & 12,1 & $1950-1980$ & $1950-1990$ \\
\hline Hornsherred & 22,1 & 22,8 & 22,3 & $1950-1984$ & $1950-1990$ \\
\hline$\varnothing v r i g e$ sommerhusbyer & 11,4 & 9,2 & 10,8 & $(1946)-1969$ & $1950-1989$ \\
\hline Total & 100 & 100 & 100 & $1950-1984$ & $1950-1990$ \\
\hline
\end{tabular}

Kilde: Henvisninger under Appendix VI.

Af disse udgjorde kystbæltet langs Roskilde Fjords nord- og østside det nærmeste kystnære område i hovedstadsmetropolens åbne land, der i midten af det 20. århundrede endnu ikke var blevet bebygget i videre omfang. Da kystbæltet udstykkedes i løbet af den første del af 50 'erne og dets syv sommerhusbyer i dette årti og særlig i 60 'erne bebyggedes i et så betydeligt omfang, at de kom til rumme mere end en ottendel af hovedstadsmetropolens samlede mængde sommerhuse, blev udbuddet af ledige grunde også her gradvist reduceret med stigende grundpriser til følge.

Selv om Hornherred omfattede en ældre stor sommerhusby, og større sommerhusudstykninger- og bebyggelser var påbegyndt på halvøens nordvestlige del ud til Isefjorden i løbet af 50'erne, blev det først i løbet af 60' ere, at der her gennemførtes vidtgående udstykninger og bebyggelser. Samlet kom Hornsherreds 18 sommerhusbyer ved udgangen af den første efterkrigstid til at omfatte godt en femtedel af hovedstadsmetropolens sommerhusvolumen. ${ }^{8}$ Den sidst tiendedel heraf blev i efterkrigstiden lokaliseret til to ældre sommerhusbyer ved Køge Bugts øst- og sydside og 17 nye sommerhusbyer. Spredt på det $\varnothing v$ rige Nordøstsjælland, men hovedsagelige ved dettes store søer og i udkanten af hovedstadsmetropolens nordforstæder. ${ }^{9}$

\section{Sommerhusbyernes bystruktur}

Endskønt hovedstadsmetropolens sommerhusbyer i efterkrigstidsperioden fordelte sig forskelligartet såvel tidsmæssigt som geografiske i metropolens åbne land, fik de en række fællestræk. Det drejede sig om de størrelseskategorier, disse fordelte sig på og den bebyggelsesmæssige struktur og udvikling, der kendetegnende dem. Sommerhusbyerne fik desuden en social sammensætning, der blev markant forskellig fra hovedstadsmetropolen som helhed, og deres sommerhuse kom til at adskille sig signifikant fra mellemkrigstidens og 40 'ernes. Herudover skabte sommerhusbyernes volumen og regionale fordeling et grundlag for en egentlig erhvervsmæssig udvikling i perioden, ligesom el- og vandforsyningen og håndteringen af spildevandsafledning fik en række fællestræk.

\section{Bebyggelse}

Af efterkrigstidens samlede 40.000 sommerhuse i hovedstadsmetropolen blev tre fjerdedele opført i de knapt 40 procent af de 72 sommerhusbyer, der omfattede mere end 500 huse (tabel III.5). Fordelt med 60 procent i den fjerdedel af sommerhusbyer, der rummede mere end 1.000 sommerhuse og med 15 procent i de 14 procent af sommerhusbyerne, som omfattede mellem 500-1.000 huse. Med denne betydelige koncentration blev alene en fjerdel af hovedstadsmetrolens efterkrigstidssommerhuse lokaliseret til de 60 procent af mellemstore og mindre sommerhusbyerne, der rumme op til 500 sommerhuse. 
Tabel III.5. Procentvis fordeling efter sommerhusbyers størrelse, hovedstadsmetropolen, 1950-1990

\begin{tabular}{|l|l|l|}
\hline & $\begin{array}{l}\text { Procentvis fordeling efter antal } \\
\text { huse }\end{array}$ & Antal sommerhusbyer \\
\hline Store sommerhusbyer (over 1.000 huse) & 60,6 & 25,6 \\
\hline Støre sommerhusbyer (500-999 huse) & 15,1 & 13,5 \\
\hline Mellemstore sommerhusbyer (200-499) & 17,5 & 32,7 \\
\hline Mindre sommerhusbyer (Mindre end 199) & 6,8 & 28,2 \\
\hline Total & 100 & 100 \\
\hline
\end{tabular}

Kilde: Henvisninger under Appendix VI.

Lige på nær det fătal af sommerhusbyer, der med godt en procent af hovedstadsmetropolens samlede sommerhusvolumen i efterkrigstiden opførtes i de indre dele af metropolens åbne land, opstod sommerhusbyerne ved kyst-, fjord- eller søbredder. Uanset om sommerhusbyerne på disse lokaliteter var opstået før midten af det 20. århundrede og i efterkrigstiden udvidedes på dette grundlag eller de i perioden opstod som nye, fik de alle en karakteristisk bebyggelsesstruktur. Ud fra den tidligste bebyggelse langs kyst-, fjord- eller søbredderne dannedes der således tidsmæssigt forskudte flere koncentriske bebyggelseslag langs side- og parallelveje til veje langs bredderne eller til sideveje, der fra det rurale bagland førte frem til disse. I de mindre og mellemstore sommerhusbyer med bebyggelse på nogle hundrede meter både langs kyst-, fjord- eller søbredderne og ind i baglandet. I de større og store sommerhusbyer med bebyggelser med en udtrækning på over en km såvel langs disse bredderne som ind i baglandet. Ved Kattegatkysten i form af et næsten uafbrudt $50 \mathrm{~km}$ langt bebygget kystbælte, der strakte sig op til seks km ind i baglandet.

Mens vej- og bebyggelsesstrukturen blev mere ensartet og sammenhængende i hovedstadsmetropolens efterkrigstidssommerhusbyer, som følge af en mere indgribende lokalkommunal planindsat, kunne den ikke hindre en stærk koncentreret bebyggelse. Af hensyn til størst mulig fortjeneste lykkedes det således for de udstykkende at fă udparcelleret så mange sommergrunde som muligt. Med den konsekvens for de enkelte sommerhusbyer, at stedlige højdedrag, mindre plantager og i realiteten uanvendelige engarealer senere bebyggedes, og at der ofte ikke udlagdes fællesarealer, eller at disse fik et yderst begrænset omfang og ikke kom til at indgå i en rationel sammenhæng med selve sommerhusbebyggelsen. ${ }^{10}$

Tabel III.6. Procentvis social sammensætning af førstegangssommerhusejere i hovedstadsmetropolen sommerhusbyer, 19501973, og af erhvervsbeskæftigede i hovedstadsmetropolen, 1950 og 1970.

\begin{tabular}{|c|c|c|c|c|c|c|}
\hline \multirow[t]{3}{*}{ Stilling } & \multirow{3}{*}{\multicolumn{2}{|c|}{$\begin{array}{l}\text { Sommerhusejere, } \\
1950-1973\end{array}$}} & \multicolumn{4}{|c|}{$\begin{array}{l}\text { Hovedstadsmetropolens erhvervsbeskæftigede } \\
\text { befolkning }\end{array}$} \\
\hline & & & \multicolumn{2}{|c|}{1950} & \multicolumn{2}{|c|}{1970} \\
\hline & & & Hovedstaden & Forstæder & Hovedstaden & Forstæder \\
\hline Større selvstændige & 6,6 & & & & & \\
\hline Mindre selvstændige & 15,5 & & & & & \\
\hline Selvstændige, total & & 22,1 & 11,7 & 17,4 & 7,1 & 9,5 \\
\hline Ledende funktionærer & 7,1 & & & & & \\
\hline Akademisk uddannede funktionærer & 9,6 & & & & & \\
\hline Højere funktionærer, i alt & 16,7 & & & & & \\
\hline$\varnothing$ vrige funktionærer & 42,9 & & & & & \\
\hline Funktionærer, total & & 59,6 & 33,0 & 24,2 & 42,6 & 44,6 \\
\hline Faglærte arbejdere & 15,4 & & & & & \\
\hline Ufaglærte arbejdere & 2,9 & & & & & \\
\hline Arbejdere, total & & 18,3 & 53,3 & 58,4 & 50,0 & 44,1 \\
\hline Total & 100 & 100 & 100 & 100 & 100 & 100 \\
\hline
\end{tabular}

Kilde: Henvisninger under Appendix VI. Bro: Hovedstadsmetropolen- den danske byregion, 2020, s. 547-548.

\section{Social sammensætning}

Da hovedstadsmetropolens sommerhusbyer alene havde en fritidsmæssig bosætningsfunktion, blev den sociale sammensætning af sommerhusejerne et centralt træk ved disses bymæssige karakter (tabel III.6). ${ }^{11}$ Endskønt arbejderklassens andel af erhvervsbeskæftigede i hovedstadsmetropolen i den første efterkrigstid alene faldt fra over 50 procent til under 45, 
kom den kun til at udgøre godt 18 procent af periodens førstegangssommerhusejere i metropolen. ${ }^{12}$ I forhold til mellemkrigstidens og 40 'erne og endog arbejderklassens faldende andel af erhvervsbeskæftigede i den førte efterkrigstid betegnede det ganske vist en forøgelse på syv procentpoints og dermed en vis social udjævning i sommerhusejerforholdet, men både funktionærer og selvstændige forblev stærkt overrepræsenteret i periodens sommerhusbyer i hovedstadsmetropolen.

Tabel III.7. Procentvis fordeling af bopælsområde og boligform for førstegangssommerhusejere i hovedstadsmetropolens sommerhusbyer, 1950-1973, og i hovedstadsmetropolen, 1950 og 1970.

\begin{tabular}{|l|l|l|l|}
\hline & Sommerhusejere & Hele hovedstadsmetropolens befolkning \\
\hline Bopæl i: & $1950-1973$ & 1950 & 1970 \\
\hline Hovedstaden & 50,2 & 61,9 & 41,8 \\
\hline Nordegnen & 21,2 & 12,2 & 13,5 \\
\hline Nordvestegnen & 11,7 & 3,8 & 8,5 \\
\hline Vestegnen & 12,0 & 7,0 & 15,4 \\
\hline Andet & 4,9 & 15,1 & 20,8 \\
\hline Total & 100 & 100 & 100 \\
\hline Etagebolig & 58,4 & 82,3 & 74,7 \\
\hline Enfamiliehuse & 41,6 & 17,7 & 25,3 \\
\hline Total & 100 & 100 & 100 \\
\hline
\end{tabular}

Anm: Fordelingen på etageboliger og enfamiliehuse omfatter alene hovedstaden og forstadsegnene

Kilde: Henvisninger under Appendix VI.Statistiske Årbog for København, Frederiksberg m.m., 1952, s. 1, 55, 191-192

og 198. https://www.kk.dk/sites/default/files/migrated/sc/1972-aarbog.pdf

https://www.kk.dk/sites/default/files/migrated/sc/1975-aarbog.pdf

På trods af andelen af erhvervsbeskæftigede funktionærer og selvstændige i

hovedstadsmetropolen i perioden henholdsvis forøgedes og reduceredes fra 33 til 44 og fra 17 til 7 procent, opnåede de to grupper en andel af førstegangssommerhusejere i metropolens sommerhusbyer på 60 og 22 procent. I forhold til mellemkrigstiden og 40 'erne var der tale om en forøgelse af ejerandelen på 10 procentpoints for funktionærlagets vedkommende og en reduktion på 14 procentpoints for gruppen af selvstændige, men med ganske betydelige forskydninger inden de to sociale hovedgruppe. Blandt selvstændige reduceredes andelen af førstegangssommerhusejere i efterkrigstiden i forhold til mellemkrigstiden og 40 ' erne med 7,4 procent for støre selvstændige og 9,5 procentpoints for små selvstændige ${ }^{13}$, mens samme ejerandel inden for funktionærlaget henholdsvis faldt med 9,3 for laget af højere funktionærer og forøgedes med næsten en femtedel for gruppen af øvrige funktioner. ${ }^{14}$

En i forhold til mellemkrigstiden og 40'erne en ikke ubetydelige social udjævning af ejendomsforholdene i hovedstadsmetropolens sommerhusbyer, der dog ikke blev større end, at fordelingen af førstegangssommerhusejere i metropolens sommerhusbyer i forhold til sammensætningen af erhvervsbeskæftigede i hovedstadsmetropolen blev et af mange eksempler på den første efterkrigstids forsatte sociale ulighed, og at det i særlig grad blev mellemlaget, der opnåede de største fordele ved periodens økonomiske vækst og velfærdstatslige omfordeling. En omfordeling til mellemlagets fordel, der dog ikke ændrede ved, at laget af større selvstædige og højere funktionærer i den første efterkrigstid endnu udgjorde næsten en fjerdel af førstegangssommerhusejerne i hovedstadsmetropolens sommerhusbyer.

En social skævhed, der tillige satte sig igennem i forhold til førstegangsommerhusejernes bopæl i hovedstadsmetropolen og umiddelbare boligforhold (tabel III.7) Ejergruppen beboede således i langt højere grad end hovedstadsmetropolens befolkning et enfamiliehus, og havde i højere grad bopæl i metropolens nordlige velhaverforstæder og de noget bedre stillede forstæder på Nordvestegnen. Den meget lavere andel af førstegangssommerhusejere uden for hovedstadsmetropolens centrale del var derimod betinget af, at disse dele både lå tættere på metropolens åbne og rekreative opland, og i vid udstrækning omfattede enfamiliehuse med egen have og dermed med mulighed for et friluftliv inden for disse rammer. 
Tabel III.8. Skattepligtig procentvise indkomstfordeling på tiendedele efter stigende skattepligtig indkomst, hele landet, 1949-1968.

\begin{tabular}{|l|l|l|}
\hline Tiendedele & 1949 & 1968 \\
\hline 1. & 1,5 & 1,0 \\
\hline 2. & 3,3 & 3,1 \\
\hline 3. & 4,5 & 4,3 \\
\hline 4. & 6,0 & 5,2 \\
\hline 5. & 7,2 & 7,1 \\
\hline 6. & 9,1 & 9,1 \\
\hline 7. & 10,7 & 10,9 \\
\hline 8. & 12,7 & 13,1 \\
\hline 9. & 15,5 & 16,2 \\
\hline 10. & 29,5 & 30,0 \\
\hline Total & 100 & 100 \\
\hline Udjærningsprocent & 28,1 & 30,2 \\
\hline
\end{tabular}

Kilde. ${ }^{15}$ Anm. Udjævningsprocent: Den maksimale udjævningsprocent

Selv om varige forbrugsgoders andel af det samlede forbrug, hvori sommerhusbesiddelse indgik, samlet fordobles i den første efterkrigstid, var det den socialt skæve fordeling af førstegangsommerhusejere i hovedstadsmetropolens sommerhusbyer et udtryk for, at disse goder ikke blev markant jævnere socialt fordelt. Skønt fagbevægelsen som følge af den fulde beskæftigelse kunne hente betydelige reallønstigninger hjem til arbejderbefolkningen, og det socialt sikrende og omfordelende velfærdssystem udvidedes i takt med den første efterkrigstids udbygningen af velfærdsstaten, var det ikke nok til yderligere at udjævne den indkomstmæssige ulighed, der var opnået op genemme $30^{\prime}$ - og 40 'erne.

Tabel III.9. Anvendelse af ferien til ophold i eget sommerhus procentvis fordelt på social- og indkomstgrupper, hele landet, 1974.

\begin{tabular}{|l|l|l|l|}
\hline Socialgrupper & Ferie i eget sommerhus & Indkomstgrupper & Ferie i eget sommerhus \\
\hline I & 33 & Under 20.000 & 5 \\
\hline II & 12 & $20.000-39.999$ & 4 \\
\hline III & 10 & $40.000-59.999$ & 5 \\
\hline IV & 10 & $60.000-79.999$ & 8 \\
\hline V & 6 & $80.000-99.999$ & 11 \\
\hline $\begin{array}{l}\text { 8 procent af befolkningen anvendte samme àr ferien i eget } \\
\text { sommerhus. Indkomstgrupper: Familiernes bruttoindkomst i kr. }\end{array}$ & $100.000-149.999$ & 14 \\
\hline
\end{tabular}
Kilde. ${ }^{16}$

Navnlig privatansatte funktionærer og særlig dem på et højere niveau, samt større virksomhedsejere opnåede en så langt stærkere indkomstudvikling end arbejdere, offentligt ansatte funktionærer og mindre selvstændige, at den maksimale udjævningsprocent forøgedes en smule fra 1949 til 1968 (tabel III.8). For de tre tiendedele med de højeste indkomster udvidedes andelen af den samlede indkomst i perioden fra 57,7 i 1949 til 59,3 procent i 1968, mens samme andel for de to to-tiendedele med de laveste indkomster i samme periode reduceredes fra 4,8 og 10,5 procent til 4,1 og 9,5 procent. For de mellemliggende tre tidendedele i indkomstskalaen $\varnothing$ gedes andelen af den samlede indkomst alene fra 27,0 procent i 1949 til 27,1 procent i $1968 .^{17}$

Den ujævne indkomstfordeling satte sig tydeligt igennem ved fordelingen af det varige, men yderst marginale varige forbrugsgode, som et sommerhus repræsenterede både som påvist $\mathrm{i}$ hovedstadsmetropolen og på landsplan (tabel III.9). Ved udgangen af den første efterkrigstiden anvendte således 33 og 12 procent af landets befolkningen i socialgruppe I og II ferien til ophold i eget sommerhus, mens samme procentandele for socialgruppe III-V udgjorde henholdsvis 10,10 og 6 procent. En fordeling, der også satte sig igennem ved dette varige forbrugsgodes fordeling på bruttoindkomstgrupper. Mellem 5 og 8 procent $i$ indkomstgrupperne op til $80.000 \mathrm{kr}$. anvendte ferien i eget sommerhus, mens samme procentandel udgjorde 11-15 procent for indkomstgrupperne over de $80.000 \mathrm{kr} .{ }^{18}$ 


\section{Sommerhusstandard}

Trods den i forhold til mellemkrigstiden og 40 ' erne noget jævnere sociale fordeling af førstegangssommerhusejere i den første efterkrigstids sommerhusbyer i

hovedstadsmetropolens åbne land, førte dette forhold ikke til, at denne perioders sommerhuse målt i parametre for sommerhusstandarden blev lavere.

I gennemsnit blev byregionens sommerhuse ganske vist $2 \mathrm{~m}^{2}$ mindre end dem, der rejste i tiden op til midten af det 20. århundrede og havde samme andel med fire eller flere værelser. Til gengæld førte den første efterkrigstids kraftige økonomiske vækst, stærkt forøgede samfundsmæssige indkomst, byggeteknologiske udvikling og lokalkommunernes forstærkede mulighed for og vilje til regulere den stedlige sommerhusbebyggelse til, at periodens sommerhuse fik en signifikant bedre kvalitet end dem, der opførtes i mellemkrigstiden og 40 'erne (tabel III.10).

Tabel III.10. Parametre for sommerhusstandarden i hovedstadsmetropolens sommerhusbyer, 1950-1973.

\begin{tabular}{|c|c|c|c|c|c|}
\hline \multirow[t]{2}{*}{ Opført, i procent: } & Som selvbyg & Af bygmester & Med arkitektbistand & Af byggefirma & Total \\
\hline & 9,9 & 24,0 & 11,2 & 54,9 & 100 \\
\hline \multicolumn{6}{|c|}{ Rumfordeling, i procent: } \\
\hline 1 rum & 2 rum & 3 rum & 4 rum & 5 el. fl. Rum & Total \\
\hline 1,8 & 22,5 & 53,2 & 16,5 & 6,1 & 100 \\
\hline \multirow[t]{2}{*}{ Toilet, i procent: } & Udenfor huset & I huset & Total & \multirow{2}{*}{\multicolumn{2}{|c|}{$\begin{array}{l}\text { 42,2 procent med bad. } \\
1,7 \text { procent uden køkken }\end{array}$}} \\
\hline & 18,4 & 81,6 & 100 & & \\
\hline Areal: & \multicolumn{2}{|c|}{ Mellem $10-190 \mathrm{~m}^{2}$.I gennemsnit $51,9 \mathrm{~m}^{2}$} & Udvidelser: & \multicolumn{2}{|c|}{ I gennemsnit $14,8 \mathrm{~m}^{2}$} \\
\hline \multicolumn{3}{|c|}{ Opført, procentfordeling: } & \multicolumn{3}{|c|}{ Forsynet, procentfordeling: } \\
\hline Af træ & Som grundmuret & Total & Med skorsten & Uden skorsten & Total \\
\hline 85,5 & 14,5 & 100 & 59,6 & 40,4 & 100 \\
\hline \multicolumn{2}{|c|}{ Opført på, procentfordeling: } & \multicolumn{2}{|c|}{ Vandforsyning, procentfordeling: } & \multicolumn{2}{|c|}{ Spildevandsafledning, procentfordeling: } \\
\hline Piller & Fundament & Udenfor hus & I hus & Ingen & Sivebrønd m.m. \\
\hline 10,1 & 89,9 & 7,9 & 92,1 & 6,3 & 93,7 \\
\hline
\end{tabular}

Kilde: Henvisninger under Appendix VI.

I forhold til denne periodes sommerhuse fik efterkrigstidens langt færre 1-2 værelses sommerhuse, mens mere end halvdelen kom til at rumme 3 værelser. Markant flere, henholdsvis 82 og 42 procent, fik installeret toilet og bad i sommerhusene, mod 37 og 10 procent i sommerhusene opført før midten af århundrede, på samme tid som huse uden køkken blev forsvindende. Over 60 procent den første efterkrigstids sommerhuse blev fuldisolerede, mens denne beskyttelse mod kulde og vand alene opnåedes i de 14 procent af mellemkrigstidens og 40 'erne sommerhuse, der var grundmurede.

Størrelsesforholdet mellem grundmurede og af træ opførte sommerhuse forblev ganske vist det samme i den første efterkrigstid som i perioden op til 1950, men til gengæld blev 90 procent af efterkrigstidssommerhusene opført på et støbt fundament, mens det alene drejede sig om tre fjerdedele i de ældre sommerhuse. Endelig udrustedes den første efterkrigstids sommerhuse i langt højere grad med faciliteter end sommerhusene fra mellemkrigstiden og 40 'erne. Andelen af sommerhuse med de opvarmningsmuligheder som en skorsten gav, forøgedes 53 til 59 procent, på samme tid elpaneler i den første efterkrigstid gav en ny opvarmningsmulighed i huse uden skorsten. Af sommerhuse med indlagt vand og spildevandsafledning til sivebrønd eller septiktank øgedes andel fra 86 og 77 procent i huse opført i perioden før midten af det 20. århundrede til 92 og 94 procent i efterkrigstidssommerhusene.

En af de mest markante træk ved efterkrigstidens sommmerhusbyer blev sammensætningen af de aktører, der stod bag sommerhusbyggeriet. En sammensætning, der i forhold til sommerhusbyggeriet op til midten af det 20 . århundrede ændrede sig markant med den første efterkrigstids sommerhusboom. 
Selv om selvbyg både ved opførelse af enfamilie- og sommerhuse også blev ganske udbredt i den første efterkrigstid, faldt andelen af selvbyggede sommerhuse fra 16 procent før midten af århundrede til 10 procent. Samtidig reduceredes andelen af sommerhuse flikket sammen af håndværksmestre mellem de to perioder med 17 procentpoints, mens andelen huse opført med arkitektbistand faldt med 27 procentpoint. Disse forskydninger blev betinget af den meget store rolle, typesommerhuset fik i den første efterkrigstid. Mens kun et beskedent antal byggefirmaer alene havde stået bag fem procent af de sommerhuse, der opførtes i mellemkrigstiden og 40'erne, førte den første efterkrigstids sommerhusboom til, at ikke mindre end 55 procent af husene i hovedstadsmetropolens sommerhusbyer blev tilvejebragt af 67 firmaer, der havde specialiseret sig i produktion af typesommerhuse; heraf 57 danske og ti fra det $\varnothing$ vrige Skandinavien (APPENDIX VIII). ${ }^{19}$

\section{Forsyning}

Allerede inden midten af det 20. århundrede havde NESA varetaget elektricitetsforsyningen af samtlige sommerhusbyer i hovedstadsmetropolens sommerhusbyer, og det blev da også dette af Gentofte Kommune ejede elektricitetsselskab, der fik forsyningsopgaven i takt med disse byer udbyggedes i efterkrigstiden og de nye, der opstod i perioden. Da der i hovedparten af de sommerhusbyer, der i efterkrigstiden udvidedes på grundlag af sommerhusbydannelse fra mellemkrigstiden og 40 'erne, allerede her var etableret lokale vandværker, og en del af periodens nye sommerhusbyer lå så tæt ved nærmeste købstad, stationsby eller større landsby, at disses vandforsyningsanlæg kunne udvides hertil, opnåede i 47,5 procent af periodens sommerhuse vandforsyning fra allerede eksisterende kommunale eller private, ofte andelsejede, vandværker.

For den større halvdel af sommerhusene i efterkrigstidens sommerhusbyer, i hovedsagen dem der opstod i perioden i mere isolerede dele af hovedstadsmetropolens fjernere åbne land, måtte vandforsyningen derimod etableres fra grunden. I sommerhusbyer med 16,3 procent af hovedstadsmetropolens samlede sommerhusvolumen pătog lokalkommunerne sig vandindvindingsopgaven, mens den i de øvrige sommerhusbyer, med 36,2 procent af sommerhusene, blev overladt til de stedlige grudejerforeninger, der etablerede såvel vandværker og hovedvandforsyningsnet (APPENDIX VII).

Opnåedes der i efterkrigstiden en fuldstændig elektricitets- og vandforsyning i hovedstadsmetropolens sommerhusbyer, og disses vejsystemer samtidig udlagdes af de stedlige udstykkere eller grudejerforeninger, kneb det med den del af byggemodningen, der omfattede offentlig kloakering. Ved udgangen af efterkrigstidsperioden i 1990 var der således kun gennemført en delvis kloakering af hovedstadsmetropolens sommerhusbyer, hvorved alene knapt 52 procent af dens sommerhuse var blevet tilsluttet et offentlig kloanet og dermed den spildevandsbehandling, som det samtidig større antal lokalkommunale rensningsanlæg muliggjorde. I en meget betydelige del af sommerhusbyerne, med den mindre halvdel af metropolens sommerhuse, forblev spildevandsafledningen i efterkrigstiden dermed baseret på sivebrønde eller septiktanke.

Den eneste formildende faktor i den forbindelse var, at 95 procent af hovedstadsmetropolens sommerhuse tilsluttedes sådanne spildevandsanlæg, hvorved den tidligere ganske udbredt nedgravning af fækalier og udhældning af urin og husholdningsspildevand på de enkelte grunde eller i nærmeste vandløb stoppede. At grundvandsnedsivning fra sivebrønde eller ulovlig anvendelse af septiktanke blev mere udbredt, blev så en ny miljøudfordring.

\section{Erhverv}

Mens nærmest liggende fiskerlejer, større landsbyer, stationsbyer, købstæder eller forstadsbydele dækkede behovet for dagligvareindkøb og håndværksmæssige ydelser $\mathrm{i}$ et betydeligt antal af efterkrigstiden sommerhusbyer i hovedstadsmetropolens åbne opland, skabte periodens sommerhusbydannelse grundlag for en byerhvervsmæssig udvikling i knapt en tredjedel af sommerhusbyerne, som rummede 57 procent af metropolens 
sommerhusvolumen. I hovedsagen i de store, større og i nogle tilfælde også mellemstore sommerhusbyer, der lå tilpas langt fra en større eksisterende bebyggelse, og samtidig havde et volumen, som muliggjorde en selvstændig erhvervsudvikling.

Faktorer, der samtidig blev afgørende for, hvor differentieret erhvervsstrukturen blev i de enkelte sommerhusbyer. Nogle fik således kun en enkelt købmandshandel, et mælkeudsalg eller et mindre supermarked, mens de store sommerhusbyer fik forskellige former for detailhandel og håndværksvirksomhed. Det være sig bageri, ismejeri, slagterforretning, købmandshandler, supermark og blomsterforretning, der nogle steder koncentrerede sig til selvgroede centerområde ved en gennemgående større vej. Hertil kom planteskole, tømrer- og snedkerværksted, autoværksted, VVS-virksomhed, tømmerhandel, autolakereri, cykelforretning, benzintank, vognmandsforretning, cafeteria, resturent, flere is- og pølseudsalg, grill, motel og diskotek.

Ud over de badehoteller, pensionater, kurbadeanstalter, ferie- og sommerlejre, der forsatte virksomheden, blev der til de store og større sommerbysbyer i efterkrigstiden samtidig knyttet vandrehjem og anden virksomhed, der tilbød alternativ fritidsbosætning til sommerhusene. Det være sig flere ferie- og hvilehjem, de to kolonier med småhytter, som motorcykelklubben Ariel etablerede, de campingpladser, som almennyttige Danmark Lejrsport, senere Dansk Campingunion, og private udlagde ved 10 af sommerhusbyerne og de fire feriebyer - eller kolonier med småhuse og fælleslokaler med et stadig større udbud af aktiviteter, som arbejderbevægelsen, Dansk Folkeferie og fagforbund, stod bag. Hertil kom kursus- og feriecenter, efter- og specialskoler og et større antal nye ferie- og sommerkolonier. ${ }^{20}$

\section{Variationerne}

Selv om efterkrigstidens sommerhusbyers lokalisering, bystruktur, sociale sammensætning og sommerhuskvaliteter i den første del af perioden havde en række fællestræk, var der en række betydelige delregionale variationer byerne imellem. Lokaliseringen af disse i

hovedstadsmetropolens åbne land blev afgørende for sommerhusbyernes forskelligartede forudsætninger, udviklingsmønster, karakter og sociale sammensætning og dermed de varierede træk, der kendetegnede kvaliteten og arten af byernes sommerhuse. Variationer, der tillige omfattede sommerhusbyernes forskelligartede erhvervsstruktur, og de bagved liggende forudsætninger. Hertil føjede sig betydelige regionale forskelle for så vidt håndteringen af den stedlige vandforsyning og spildevandsafledning. 


\section{Kattegatkystens sommerhusbyer}

Da der med 1940-fredningsplanen allerede var lagt barrierer for videre udvidelser af det sommerhusbybælte, der var opstået langs Køge Bugt, og det i den første efterkrigstid opslugtes som et villaområde i det radiale forstadsbånd, som lagde sig langs bugten, lokaliseredes den første efterkrigstids sommerhusboom til de dele af hovedstadsmetropolens åbne opland, der som udgangspunkt havde de bedste betingelser herfor.

\section{Lokalisering}

Med de særlige historiske og naturgivne forudsætninger blev det i første omgang til Kattegatkysten i form af en massiv udvidelse af det sommerhusbybælte, der allerede her var opstået inden midten af det 20. århundrede; jf. Appendix VI.A.

\section{Kattegatkyst og bagland - et oplandsområde i hovedstadsmetropolen}

Som følge af ældre sommervillabebyggelser og mellemkrigstidens og 40 'ernes første sommerhusboom blev det $50 \mathrm{~km}$ lange kystbæltet ved Kattegat således i det 20 . århundredes første halvdel forvandlet fra et spredt bebygget område med fiskerlejer af forskellig størrelse til et stort sammenhængende sommerhusbybælte. Ganske vist koncentreret omkring fiskerlejerene og syd for Tibirke Hegn og Asserbo og Lisleje plantager, men forbundet af mellemliggende sammenhængende smallere sommerhusbebyggelser på de øvrige kyststrækninger. Med 2.500 sommerhuse i midten af det 20 .århundrede omfattede Kattegats sommerhusbybælte ikke blot hovedstadsmetropolens, men hele landets største koncentration af sommerhuse. Et sommerhusbybælte, hvor laget af større selvstændige og højere funktionærer var dominerende som både sommerhusejere, landliggere på det stedlige store antal badehoteller og pensionater eller som rekonvalescenter på sammes mange kystsanatorier og kurbadeanstalter.

Samlet en friluft- og rekreationsenklave for hovedstadsmetropolens overklasse, der også omfattede et stort antal feriekolonier overvejende for samme befolkningssegment børn og uge, og en naturlig følge af de i forhold til hovedstadsmetroolens øvrige åbne land helt særlige natur- og kulturattraktionerne, der knyttede sig til det nordligste Nordsjælland: Kattegatkysten helt enestående stande og kyslandskaber, mellemliggende store plantager og baglandets kuperede karakter, skov- og søområder og ældre slotte og landsteder, der skabte en bevidsthed om sammenhængen mellem et fortidigt aristokratis sommerophold og nutidens landliggerkultur i alle dets former. Attraktioner, der optimeredes af de allerede givne gode vejog kollektivtrafikale trafikforbindelser, som i perioden forstærkedes med vejforbedringer og hyppigere trafik på privatbaner og rutebilslinjer og de servicefunktioner, der udgik fra områdes byer.

Med det behov for sådanne funktioner, der fulgte af sommerhusbybæltets fremvækst, fiskerierhvervets gode afsætningsmuligheder $i$ hovedstadsmetropolens indre del og bymæssige oplandsfunktioner i Kattegatkystens umiddelbare bagland, opnåede de stedlige fiskerlejer i den første halvdel af det 20. århundrede en betydelig vækst med en befolkningsforøgelse på mellem en tredjedel og en tredobling. Mindst udtalt i de mindre fiskerlejer Hellebæk, Rågeleje og Liseleje, der dog kom til at omfatte flere forretninger og lokale håndværksvirksomheder. Mest i Hornbæk, Gilleleje, Tisvildeleje og særlig Hundested, der alle udviklede sig til større fiskerlejer og stationsbyer med ikke blot detailforretninger og håndværksvirksomheder, men også med havneanlæg, industri, bank- og sparekassefilialer, forsyningsværker, lokalkommunale sociale institutioner, kroer, vandrehjem, børnehjem, svagbørnskolonier, kommuneskoler med mellem- og realskoleafdelinger, teknisk skole, handelsskole og kommunebibliotek. ${ }^{21}$ En udvikling, der med en befolkningsforøgelse på mere end 50 procent og en tilsvarende byerhvervsmæssig tilvækst i samme periode tillige kom til at kendetegne 
stationsbyerne, Helsinge og Græsted, længere inde i kystbaglandet, og tidligt gjorde det nordligst Nordsjælland til hovedstadsmetropolens umiddelbart åbne opland. ${ }^{22}$

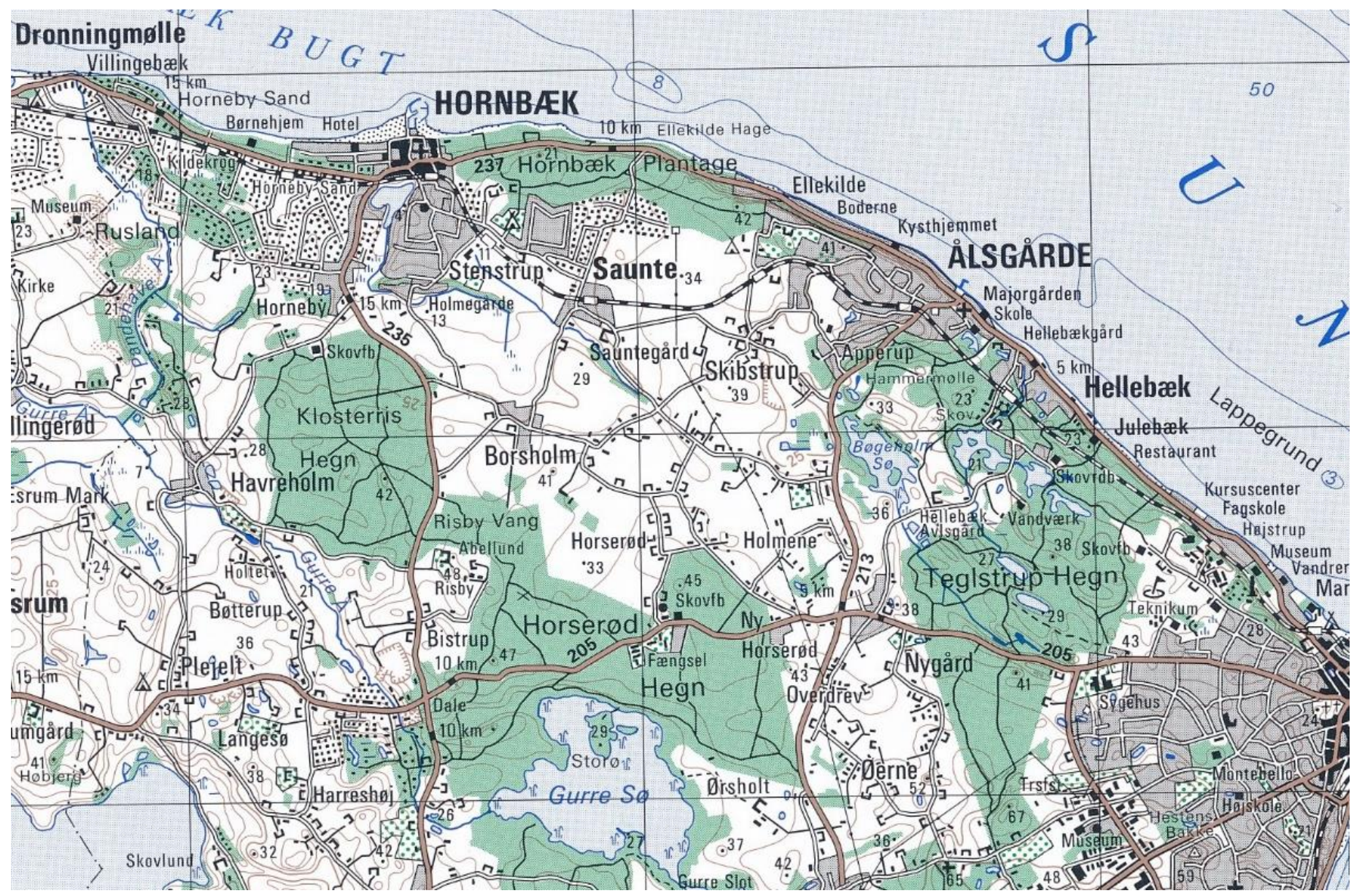

Kattegatkystens sommerhusbybælte: Helsingør-Dronningmølle. (Danmark 1:100.000, Geodætisk Institut, 2000)

\section{Kattegatkystens sommerhusbybælte}

Samlet rummede Kattegatkysten og dens opland ved midten af det 20. århundrede et sæt af attraktioner, der udgjorde en særlig tiltrækningskraft, da efterkrigstidens sommerhusboom slog igennem. Hertil kom de forberede trafikforbindelser til området, som etableredes i perioden. Ikke blot i form af hyppigere drift på eksisterende jernbane- og rutebilslinjer og oprettelse af nye rutebilsforbindelse, men i særlig grad bedre vejfremkommelighed. Ikke mindst ved åbningen af Helsingør-motorvejen på strækningen Jægersborg-Isterød allerede i 1956-1957 og motortrafikvejen Isterødvejen fra Isterød til nord for Hillerød i 1965. Herefter fulgte fuldstændiggørelsen af Helsingørmotorvejen i 1974 i form af motorgaden Hans Knudsens Plads-Jægersborg og motorvejsstrækningen mellem Isterød og Mørdrup syd for Helsingør og i 1978 forlængelsen Hillerødmotorvejen som motortrafikvej fra Allerød til vest for Hillerød. ${ }^{23}$

\section{Volumen og fordeling}

Med disse helt særegne forudsætninger blev det i efterkrigstiden, som i årtierne op mod midten af det 20.århundrede, Kattegatkysten og dens bagland, som kom til at opsuge en meget betydelig del af periodens sommerhusbyggeri i hovedstadsmetropolen. Alene adskilt af ganske betydelige plantageområder og de mindre frie kysttrækninger og grønne kiler, der sikredes af via det offentliges regionale plandispositioner, opstod der således ved Kattegatkysten i efterkrigstiden et over $50 \mathrm{~km}$ langt og 1-6 km bredt sommerhusbælte fra de ældre villakvarterer i Helsingørs vestlige yderdistrikt til nord for fiskerlejet og stationsbyen Hundested. Et sommerhusbybælte, der ved udgangen af efterkrigstiden omfattede mere end 
25.000 sommerhuse, hvoraf 10 procent var vokset frem op gennem den første halvdel af det 20. århundrede, mens de resterende 90 procent var blevet opført i efterkrigstiden.

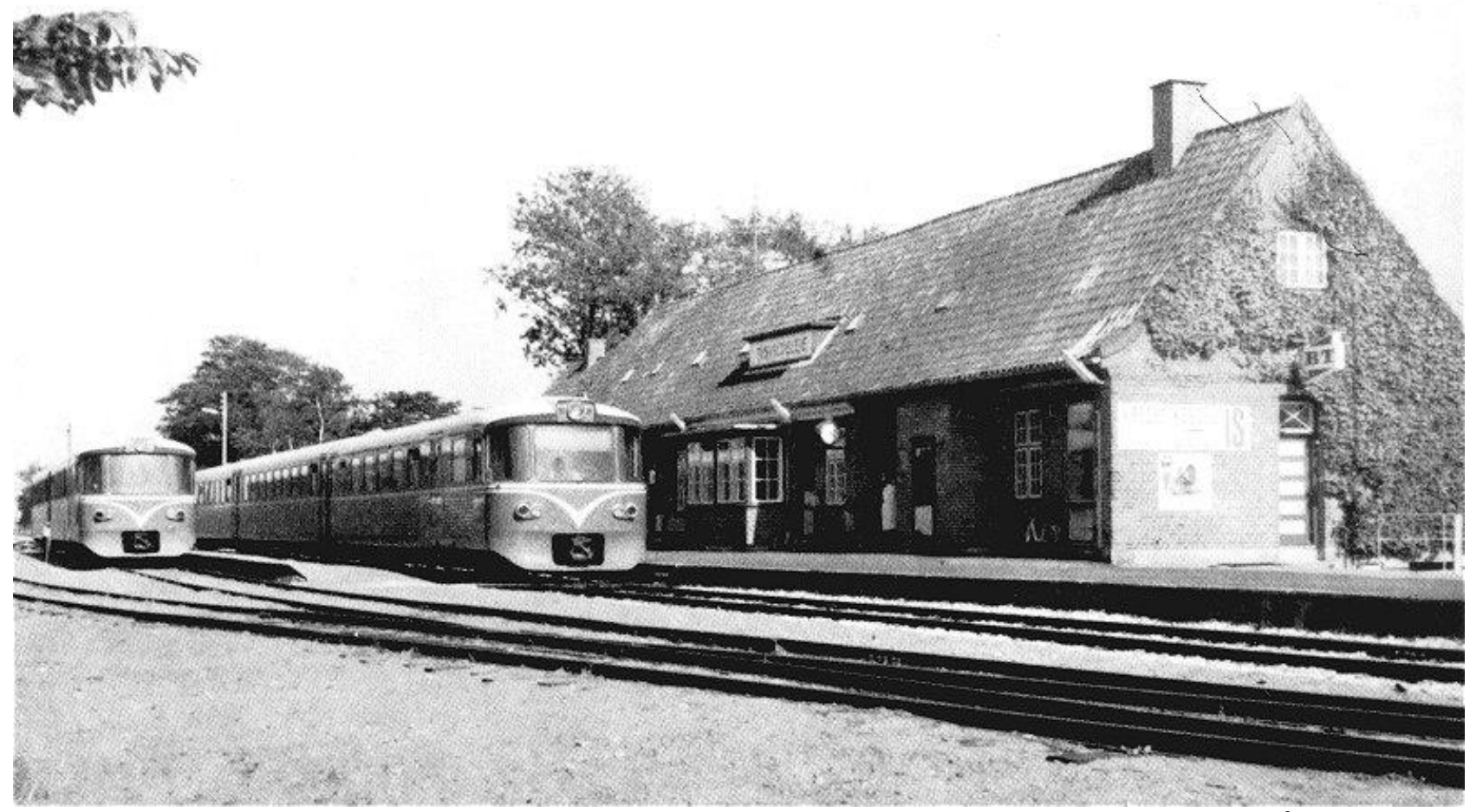

Over efterkrigstidens stærkt forberede vejforbindelser til Kattegatkystens sommerhusbybælte udvides på samme tid de kollektive trafikforbindelser hertil. I form af bl.a. den hyppigere togdrift, der tilvejebragtes gennem indsættelse af skinnebusser og de senere Y-tog, som pa billedet ses ved Tisvildeleje station $i 1974$.

Periodisk fordelt med 78 procent, svarende til 712 sommerhus pr. år, på den første del af perioden mellem 1950 og 1973, og de øvrige 22 procent, svarende til 283 sommerhuse pr., på dens sidste del frem mod 1990. Geografisk fordelt, tabel III. 11, med: Dels under 10 procent på sommerhusbybæltes henholdsvis østligste del, som på strækningen Helsingør-Hornbæk tidligt udbyggedes, og vestligste del på Halsnæs, der som følge halvøens fjernere beliggenhed i hovedstadsmetropolen udbyggedes i den sidste efterkrigstid, og hvor der samtidig var naturgive arealmæssige grænser for sommerhusbyerne udbredelse. Dels med mere end 90 procent på bæltes centrale dele mellem Hornbæk og Liseleje fordelt med omkring 20 procent på hver dettes fire delområder, hvor de ældre og mest attraktive områder mellem Hornbæk og Tibirke i større omfang bebyggedes i den første efterkrigstid, mens indlandssommerhusbyen Asserbo og den fjernere beliggende sommerhusby Liseleje i større omfang blev bebygget i den sidste efterkrigstid.

Tabel III.11. Procentvis fordeling af sommerhuse i sommerhusbyer ved Kattegatkysten, 1893-1990.

\begin{tabular}{|l|l|l|l|l|}
\hline Delområder & $1950-1973$ & $1974-1990$ & $1950-1990$ & $1893-1990$ \\
\hline Helsingør-Stenstrup & 2,6 & 0,9 & 2,2 & 2,1 \\
\hline Hornbæk-Nakkehoved & 17,2 & 12,6 & 16,4 & 15,5 \\
\hline Gilleleje-Rågeleje & 26,8 & 26,4 & 26,7 & 30,7 \\
\hline Vejby Strand-Tibirke & 22,2 & 17,8 & 21,3 & 20,3 \\
\hline Asserbo-Liseleje & 25,6 & 28,8 & 26,2 & 24,8 \\
\hline Halsnæ** & 5,6 & 13,5 & 7,2 & 6,6 \\
\hline Total & 100 & 100 & 100 & 100 \\
\hline
\end{tabular}

Anm.; *: Omfatter alene Halsnæs nord- og vestside. Kilde: Henvisninger under Appendix VI.A. 
Med den meget vide udbredelse, som Kattegatkysten sommerhusbybælte fik i løbet af efterkrigstiden, kom det flere steder til at vokse sammen med de samtidigt opståede yderdistrikter med helårsbeboede enfamiliehuse omkring nogle af fiskerlejerne, som dermed tillige blev pendlersatellitbyer i hovedstadsmetropolen. En funktionel transformation, som også i efterkrigstiden kendetegnede baglandets store stationsbyer, Græsted og Helsinge, og større landsbyer, og bevirkede, at Kattegats sommerhusbybælte i højere grad integreredes med hovedstadsmetropolens ydre bydannelser.

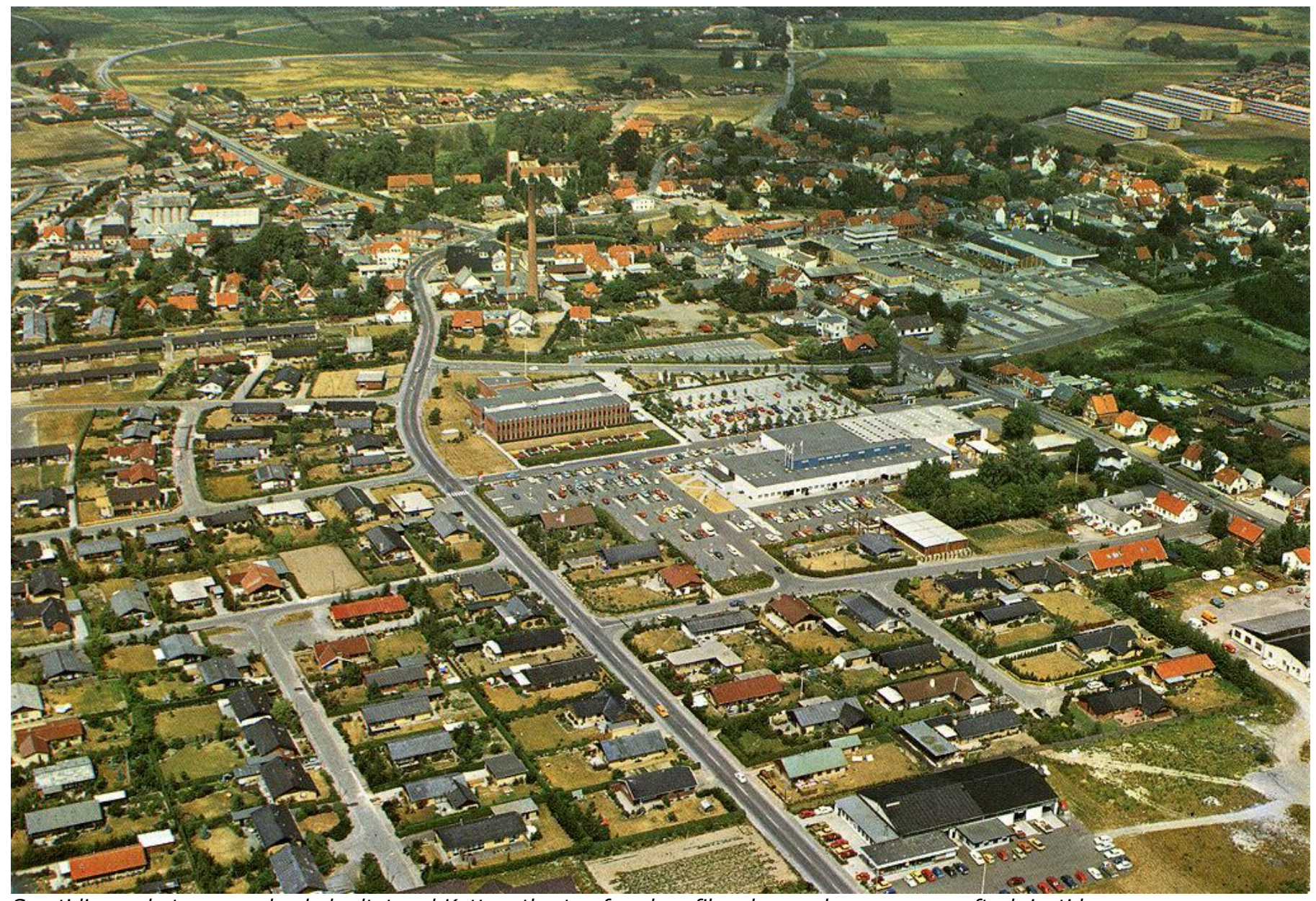

Samtidig med at sommerhusbybæltet ved Kattegatkysten for alvor fik vokseværk op gennem efterkrigstiden, forvandledes baglandets stationsbyer og større landsbyer sig til pendlersatellitbyer. F.eks. Helsinge hvor der uden om den gamle stationsby lag på lag opstod butikscentre, offentlig institutionsbyggeri, villakvarterer, kvarterer med etagebyggeri og industriområder (Luftfoto fra 1973, Gribskov Arkiv)

\section{Kystbæltet: Helsingør-Gilleleje}

I modsætning til hovedstadsmetropolens øvrige sommerhusbyer, der skød op på bar mark i efterkrigstiden tog periodens sommerhusbydannelsen ved Kattegatkysten i hovedsagen udgangspunkt i det sommerhusbybælte, der allerede inden midten af det 20 . àrhundrede var opstået her (tabel III.11 og III.12). Helt tilbage fra begyndelse af det 20. århundrede var kystbæltet mellem Helsingør og Hornbæk Plantage blevet bebygget med sommer- og helårsvillaer i et sådant omfang, at der her i efterkrigstiden kun opførtes et beskedent antal sommerhuse, der kom til at indgå i de samtidigt opståede betydelige kvarterer med helårsbeboede enfamiliehuse i Hellebæk og Âlsgårde, og som bevirkede, at de to tidligere fiskerlejer blev forstæder til Helsingør og pendlersatellitbyer i hovedstadsmetropolen.

Omkring Hornbæk kom sommerhusbyerne i efterkrigstiden til gengæld til sammen med samtidige villakvarterer helt at omsluttede de ældre dele af fiskerlejet og stationsbyen og til at tegne sig for godt ni procent af periodens sommerhuse ved Kattegatkysten. Øst byens og syd 
for Hornbæk Plantage opstod sommerhusbyen Stenstrup med udgangspunkt i en ældre sommerhusbebyggelse op til Hornbæk Plantage. Mod syd voksede yderdistriktet Holmegårde i den første efterkrigstid op som en sommerhusby, men bebyggedes senere i overvejende grad af enfamiliehuse, hvorved Hornbæk samme med andre tilsvarende bebyggelser også fik karakter af pendlersatellitby. Vest for Hornbæk omsluttedes fiskerlejet af den ældre sommerhusvillaby, der stort set var udbygget inden midten af det 20. århundrede og syd for denne af sommerhusbyen Horneby Sand. Med udgangspunkt i en ældre sommerhusbebyggelse syd for den gennemgående strandvej kom Horneby Stand op gennem efterkrigstiden til at brede sig over et tre km langt og en kilometer bredt område, som mod syd voksede sammen med et samtidigt kvarter med enfamiliehusbebyggelse for pendlere og mod vest med sommerhusbyen Villingebæk, der ud fra en ældre sommerhusbebyggelse på begge sider af den gennemgående strandvej i efterkrigsperioden bredte sig i et sydgående næsten en kilometer bredt og to km langt bælte.

Tabel III.12. Procentvis fordeling af sommerhuse samt udstyknings- og bebyggelsesperioder i sommerhusbyer ved Kattegatkysten, 1950-1990.

\begin{tabular}{|c|c|c|c|c|c|}
\hline \multirow[t]{2}{*}{ Sommerhusby } & \multicolumn{3}{|c|}{ Procentandel af antal sommerhuse } & \multirow[t]{2}{*}{ Udstykningsperiode } & \multirow[t]{2}{*}{ Bebyggelsesperiode } \\
\hline & $1950-1973$ & $1974-1990$ & $1950-1990$ & & \\
\hline Stenstrup* & 2,6 & 0,9 & 2,2 & $1958-1974$ & 1958-1985 \\
\hline Hornbæk vest & 0,1 & 0 & 0,07 & $* *$ & $1962-1971$ \\
\hline Holmegårde* & 1,8 & 0,2 & 1,4 & 1949-1967 & $1952-1976$ \\
\hline Horneby Sand & 6,5 & 4,6 & 6,1 & 1949-1974 & $1950-1986$ \\
\hline Villingebæk & 1,6 & 1,5 & 1,6 & $1956-1967$ & $1950-1987$ \\
\hline Dronningmølle & 3,7 & 3,5 & 3,9 & $1954-1967$ & $1951-1988$ \\
\hline Munkerup & 1,9 & 1,5 & 1,8 & $1951-1972$ & $1952-1984$ \\
\hline Nakkehoved & 1,6 & 1,3 & 1,5 & $1959-1967$ & $1950-1983$ \\
\hline Gilleleje Vest & 1,0 & 1,1 & 1,0 & 1951-1971 & $1953-1981$ \\
\hline Tinkerup Strand & 2,4 & 4,0 & 2,9 & $1951-1970$ & 1954-1989 \\
\hline Smidstrup Strand & 7,2 & 2,4 & 6,1 & 1952-1969 & 1954-1989 \\
\hline Udsholt Strand & 7,8 & 8,9 & 8,0 & $1952-1972$ & 1951-1985 \\
\hline Rågeleje & 8,4 & 10,0 & 8,7 & $1950-1972$ & $1950-1985$ \\
\hline Vejby Strand & 7,9 & 7,1 & 7,8 & $1950-1968$ & $1952-1984$ \\
\hline Holløselund Strand & 5,5 & 5,6 & 5,6 & $1952-1979$ & $1950-1989$ \\
\hline Tisvildeleje & 7,6 & 4,2 & 6,9 & $1950-1968$ & $1950-1983$ \\
\hline Tibirke & 1,2 & 0,9 & 1,0 & $* *$ & 1951-1985 \\
\hline Asserbo & 17,8 & 18,7 & 17,9 & $1950-1972$ & 1950-1989 \\
\hline Liseleje & 7,8 & 10,1 & 8,3 & $1952-1972$ & $1950-1986$ \\
\hline Hald Strand & 1,5 & 3,9 & 2,0 & $1952-1978$ & $1951-1988$ \\
\hline Nødebohuse & 0,7 & 1,0 & 0,7 & $1953-1974$ & $1953-1982$ \\
\hline Kikhavn & 0,3 & 0,5 & 0,3 & 1951-1961 & $1954-1985$ \\
\hline Hundested Nord & 0,6 & 1,6 & 0,8 & 1951-1976 & $1950-1988$ \\
\hline Evetofte* & 1,1 & 3,6 & 1,6 & $1960-1975$ & $1960-1986$ \\
\hline Præstelodden* & 1,4 & 2,9 & 1,8 & $1953-1973$ & $1953-1988$ \\
\hline Total & 100 & 100 & 100 & 1949-1979 & $1950-1989$ \\
\hline
\end{tabular}

Anm.: *: Sommerhusbyen er oprettet i efterkrigstidens perioden **: Bebyggelse indenfor et tidligere udstykket område. Kilde: Henvisninger under Appendix VI.A.

Et bælte, hvis videre vækst alene blev bremset af en offentligt udlagt grøn kile, der med et forløb fra baglandet og frem til kystlinjen mod øst afgrænsede de sammenhængende sommerhusbyer Dronningmølle og Munkerup. I efterkrigstiden opstod her syd for den ældre sommerhusbydannelse ved sideveje til den gennemgående strandvej et en kilomenter bredt og fem kilometer langt sammenvokset sommerhusbybælte, der ved udgangen af efterkrigstid rummede godt fem procent af Kattegatkystens sommerhuse. Med den større afstand til fikserlejerne og stationsbyer Hornbæk og Gilleleje, skabte den omfattende sommerhusbebyggelse grundlag for et større antal byerhvervsmæssige virksomheder i Dronningmølle; se afsnittet nedenfor.

Vest for den ligeledes offentligt udlagte grønne kilde ved Munkerups vestside udvikledes Nakkehoved på grundlag af en smalle stribe af ældre sommerhuse langs den fra Gilleleje mod øst gående kystvej syd herfor i efterkrigstidsperioden til en sommerhusby, der med en bredde 
op til en km. og en længde på to km voksede sammen med Gillelejes østlige ældre bykvarter med villaer og senere industrikvarter. Et erhvervsområde, der placeredes i den sydøstlige del af det meget store yderdistrikt, der med overvejende villakvarterer og enklaver med etagebyggeri, i perioden som et halvcirkelslag lagde sig syd om Gilleleje og bevirkede, at fiskerlejet og stationsyen tillige blev en pendlersatellitby i hovedstadsmetropolen. Mod sydvest smeltede yderdistriktet sammen med Gillelejes ældre vestlige bykvarter nordfor hvilket, der op mod Kattegatkysten inden midten af det 20. århundrede var opstået en sommerhusby og udstykket et betydeligt antal sommerhusrunde. Med en række supplerende udstykninger udbyggedes sommerhusbyen, og kom dermed mod vest til at omstutte de ældre dele af Gilleleje. Samlet kom sommerhusbyerne omkring Gilleleje dog kun til at udgøre godt to procent af Kattegatkystens efterkrigstidssommerhuse.

På trods af efterkrigstidens betydelige udvidelse af det over $20 \mathrm{~km}$ lange sommerhusbybæltet mellem Helsingør og Gilleleje var det inden midten af det 20. århundrede blevet udbygget så meget, at tilvæksten af nye sommerhuse i den førte efterkrigstidsperiode og særlig i den sidste efterkrigstid blev så meget mindre, at bæltets sommerhus ved udgangen af efterkrigstiden alene udgjorde knapt en femtedel af Kattegatkystens samlede sommerhusvolumen.

Hovedparten af efterkrigstidens sommerhusbyggeri i Kattegats sommerhusbælte blev dermed lokaliseret til den over $30 \mathrm{~km}$ lange strækning fra Tinkerup Strand i øst til nord for Hundested i vest.

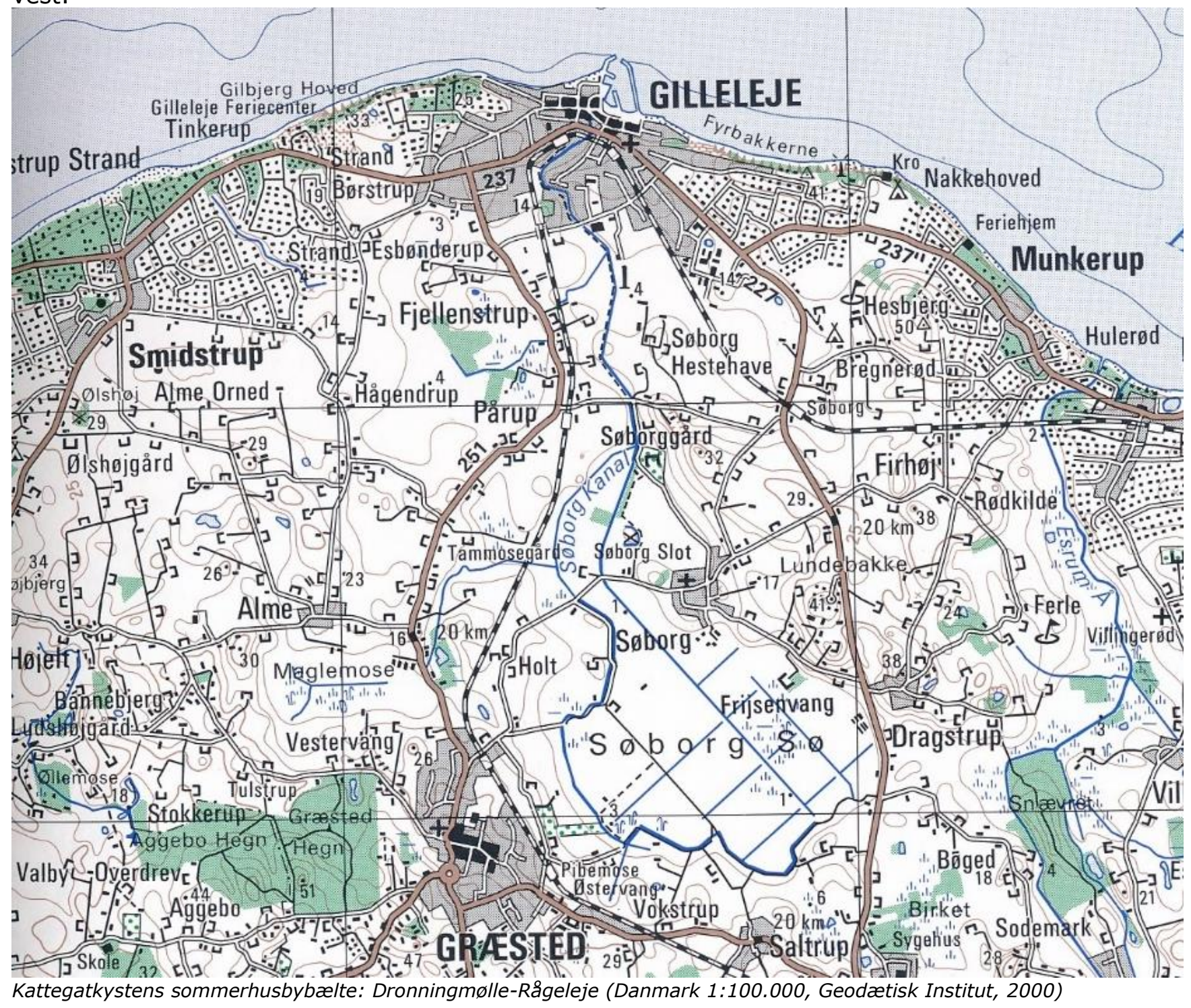




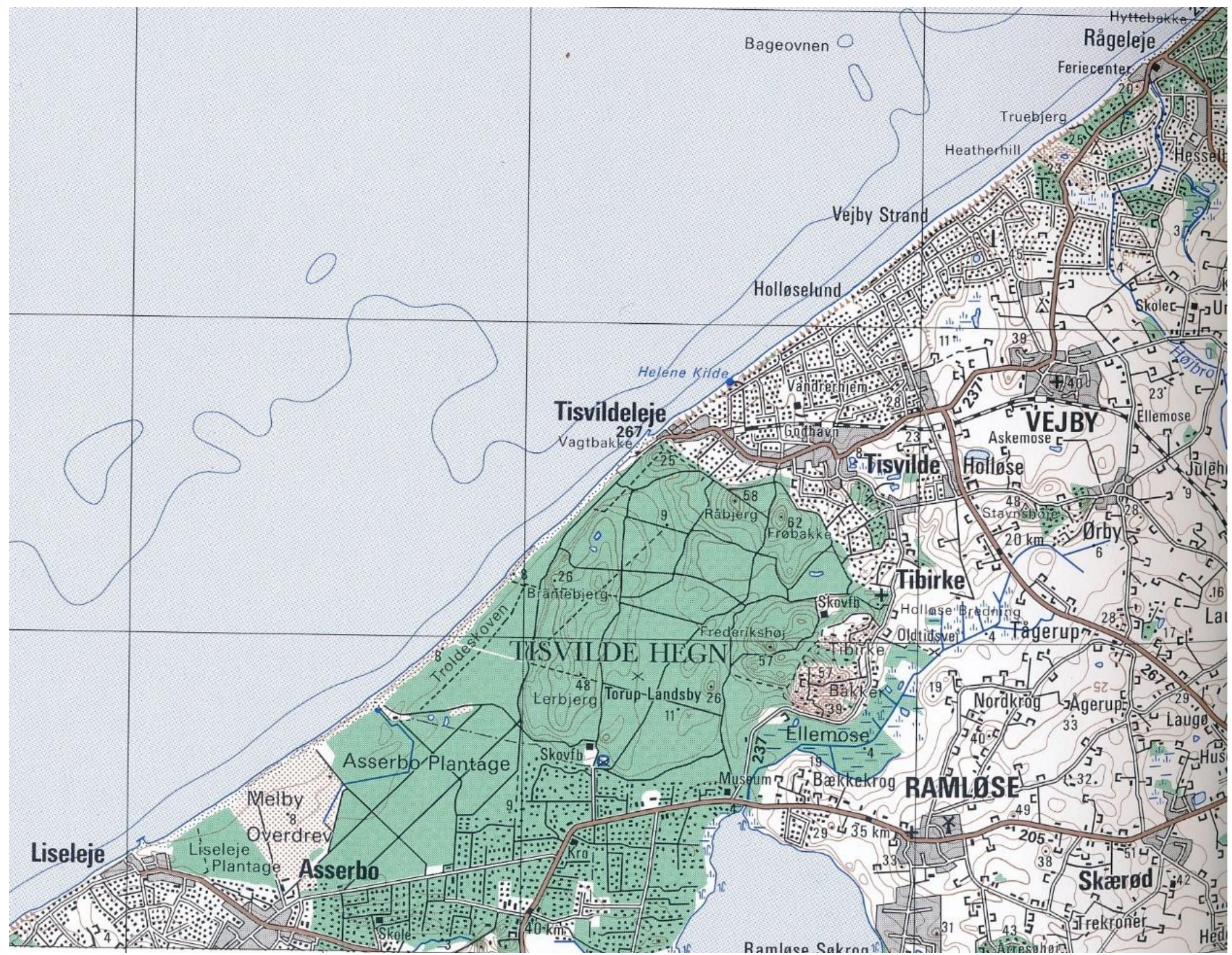

Kattegatkystens sommerhusbybælte: Rågeleje-Liseleje (Danmark 1:100.000, Geodætisk Institut, 2000)

Kystbæltet: Gilleleje-Hundested

Ved en ligeledes grøn kile blev Gilleleje mod vest adskilt fra sommerhusbyen Tinkerup, der sammensmeltet med de helt sammenhængende sommerhusbyer Smidstrup og Udsholt strande og Rågeleje, i efterkrigstiden kom til at danne et næsten $9 \mathrm{~km}$ langt sommerhusbybæltet. Med udgangspunkt i den ældre sammenhængende stribe af sommerhusbebyggelser langs og ved mindre sideveje til den gennemgående strandvej, bredte disse sommerbyer sig i efterkrigstiden som et helt sammenbygget omrăde i sydlig retning i op til to $\mathrm{km}$ ind $\mathrm{i}$ landet, og kom til at omfatte mere end en femtedel af periodens sommerhuse ved Kattegatkysten. Et volumen, der sammen med de større afstande til Gilleleje skabte grundlag for en række byerhverv i dette samlede sommerhusbyområde, som blev det en tyngdepunkt $\mathrm{i}$ efterkrigstiden sommerhusbydannelser ved Kattegats kyst.

En helt tilsvarende bebyggelsesudvikling kom til at kendetegne sommerhusbyerne Vejby og Holløselund strande, der $\mathrm{i}$ et sammenbygget sommerhusbybælte over fire km langs Kattegatkysten og med en udbredelse pă over en km ind i baglandet i efterkrigstiden løb fra den smalle offentligt udlagte grønne kile vest for Rågeleje, og mod vest voksede helt sammen med Tisvildeleje. Her var fiskerlejet og stationsbyen Tisvildeleje omkring dennes hovedgade allerede inden midten af det 20. århundrede blevet helt omsluttet af sommerhusbebyggelser. Mod øst på sideveje til den gennemgående kystvej strækkende sig i sydvestlig retning mod 
hovedgaden og fra denne helt frem mod Tisvilde Hegn. Med efterkrigstidens sommerhusboom bredte denne sommerhusbebyggelse sig som et bredt bælte yderligere tre km mod syd for her helt at omslutte landsbyen Tisvilde.

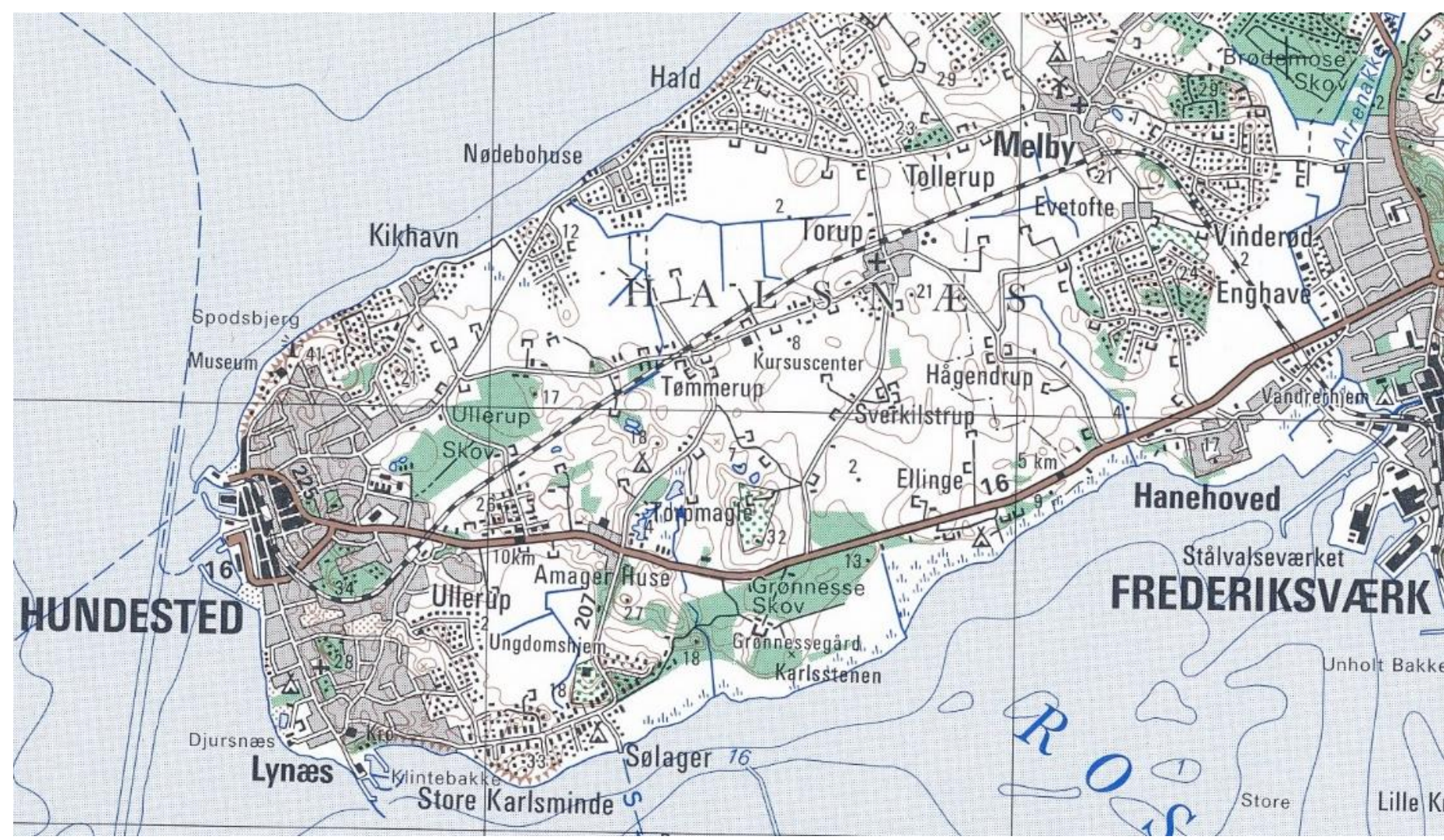

Kattegatkystens sommerhusbybælte: Halsnæsdelen (Danmark 1:100.000, Geodætisk Institut, 2000)

Ved udgangen af efterkrigstiden kom sommerhusbyen ved Tisvildeleje-Tisvilde dermed til at fremstå som et sammenhængende $3 \mathrm{~km}$ langt og bredt bebygget område, der som et halvcirkelslag strakte sig fra Kattegatkysten og til Tisvilde Hegn. Helt overvejende omfattende sommerhusbebyggelser og nogen helårsbebyggelse for pendlere og sammensmelte mod øst med den udvidede del af sommerhusbyen Holløselund Strand og mod syd med sommerhusbyen ved landsbyen Tibirke. Da Tisvildeleje-Tisvilde allerede inden midten af det 20. århundrede og i den første efterkrigstid var blevet stærkt udbygget, blev sommerhusbyggeriet her dog så meget mindre i den sidste efterkrigstid, at mængden af sommerhus pà strækningen Vejby Strand-Tibirke alene kom til at udgøre en femtedel af Kattegatkystens samlede mængde sommerhuse.

Ved landsbyen Tibirke var der tillige inden midten af det 20. århundrede opstået sommerhusbebyggelser mellem landsbyens bygade og Tisvilde Hegn og mod sydvest, adskilt af Tibirke kirke og kirkegård, i Tibirke Bakkers vidtstrakte og stærkt kuperede område syd for Tisvilde Hegn rejst spredte sommervillaer opført i overensstemmelse ved den lokale rurale bygningskultur. Efterkrigstidens sommerhusboom førte således her ikke til yderlige udstykninger og alene til en fuldstændig bebyggelse af tilbageværende ikke bebyggede parceller. Tidlige fredninger af de øvrige del af Tibirke Bakker og de syd for liggende vådområder, Holløse Bredning og Ellemose, lagde således en barriere for at Kattegatkystens sammenhængende sommerhusbybælte her bredte yderlige ind i landet og spolerede de stedlige enestående landskaber; jf. Kapitel 9.

Da der syd for den vestlige del af Tisvilde Hegn og Asserbo og Liseleje plantager ikke var truffet tilsvarende tidlige fredningsdispositioner, og området ikke frembød naturgivne 
forhindringer for byggeri, var der allerede her inden midten af de 20. århundrede op mod plantageområderne opstået et seks km langt og 1-2 km bredt sommerhusbybælte i det område, der samlet betegnedes Asserbo. Sommerhusbybæltet strakte sig fra den nordlige del af Arresø, og smeltede mod vest sammen med den sommerhusby, der på samme tid var vokset op syd for en tidlige sommerhusbebyggelse langs kysten ved Liseleje, og omfattede et en km langt sommerhusbebygget område vest for Liseleje Plantage. Et i forvejen tidligt, meget omfattende og sammenhængende sommerbyområde, der i efterkrigstiden udvides yderlige over en $\mathrm{km}$ ind $\mathrm{i}$ landet i sydlig retning og over to km vest for Liseleje Plantage.

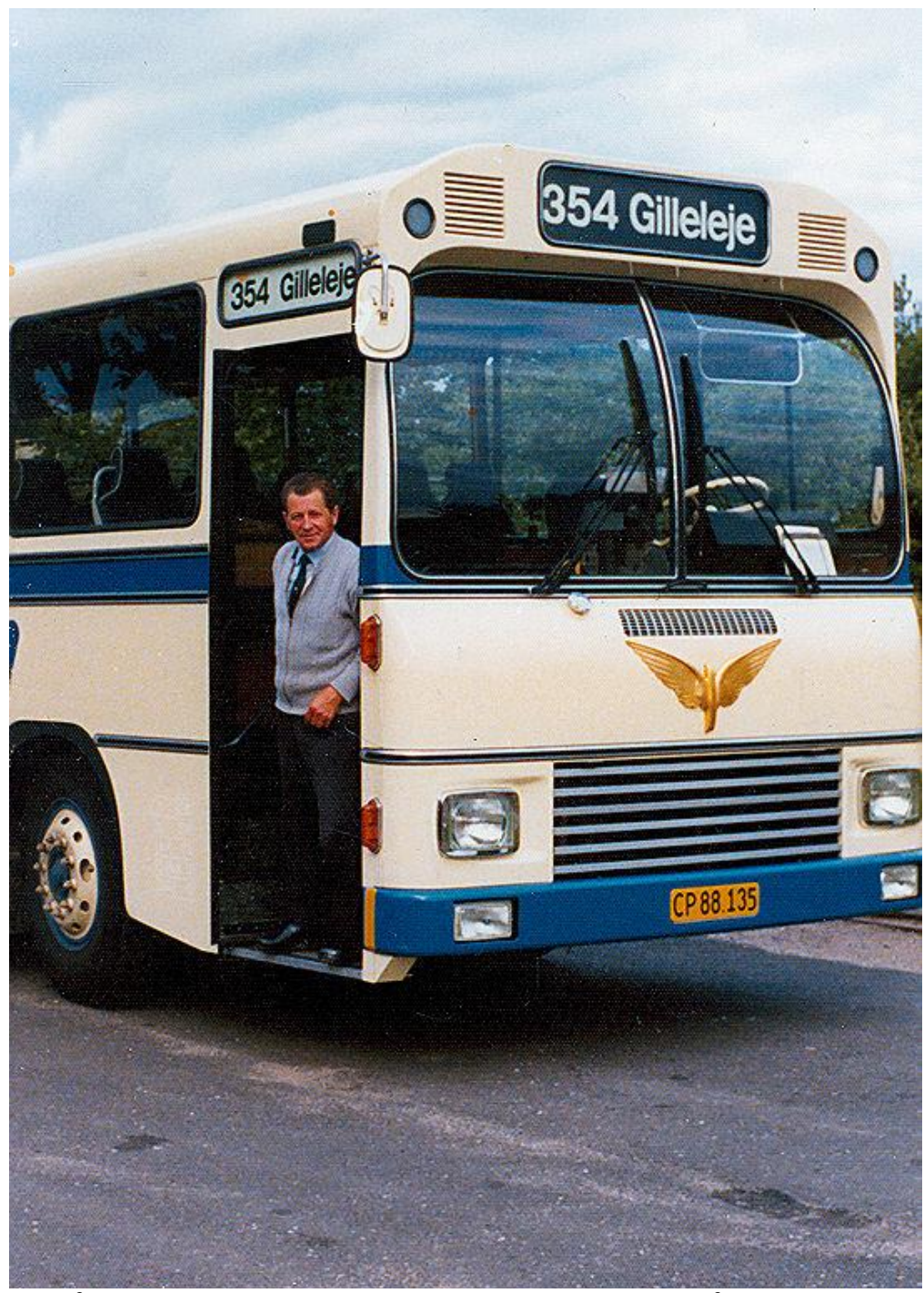

Ud over den udvidede drift p̊̊ de nordsjællandske sidebaner, gennemførte også en opgradering af den stedlige rutebilsdrift i form af i from af flere rutebilsforbindelser og anvendelse af moderne busmateriale, som denne Volvo-bus fra 1973 på Gribskovsbanens linje til Gilleleje (Gribskov Arkiv).

Med den første efterkrigstids nydannede sommerhusbyer syd for landsbyen Melby, Præstelodden og Evetofte, disses videre udbygning i den sidste efterkrigstid og sommerhusbyerne Lisleje og Asserbo, der tillige helt udbyggedes i større omfang i samme periode, tillagdes dette sommerhusbyområde en række nye byerhverv, og blev med 30 procent af Kattegatkysten sommerhuse dennes andet tyngdepunkt. Som en af landets største sommerhusbyområder fik det en sådan udstrækning, at det på nær mindre ubebyggede arealer smeltede sammen med Frederiksværks yderdistrikter, som med overvejende enfamiliehuse var vokset op på samme tidspunkt. Et samlet bebygget område, der strakte sig $\mathrm{i}$ otte $\mathrm{km}$ i nordlig retning fra Frederiksværk sydlige yderdistrikter og $\mathrm{ni} \mathrm{km}$ i vestlig retning fra 
Arresø vestside til vest for Liseleje sommerhusby, og omfattede fire sommerhusbyer og helårsbeboede yderdistrikter i Frederiksværk, der hermed tillige blev en pendlersatellitby.

På grundlag af en op til midten af det 20. århundrede opstået smal sommerhusbebyggelse på begge sider af mindre kystveje fra Liseleje i øst og til områderne nord for Hundested mod vest, dannedes med dette udgangspunkt i efterkrigstiden endelig Kattegatkystens vestligste sommerhusbybælte. Alene adskilt af mindre offentligt udlagte grønne kiler i form af et i sommerhusbyerne Hald Strand, Nødebohuse, Kikhavn og Hundested Nord sammenhængende syv $\mathrm{km}$ langt og mellem en halv og halvanden $\mathrm{km}$ bredt sommerhusbybælte, der mod vest smeltede sammen med Hundesteds nordlige yderdistrikter, som med enfamiliehus voksede op i samme periode, og tilsvarende tillige gjorde fiskerlejet og stationsbyen til en pendlersatellitby. Med de mere begrænsede arealer på Halsnæs og trods en betydelige udbygning i den sidste efterkrigstid, kom sommerhusbyerne på halvøens nord- og vestside alene til at udgøre knapt fire procent af Kattegatkystens samlede sommerhusvolumen. ${ }^{24}$

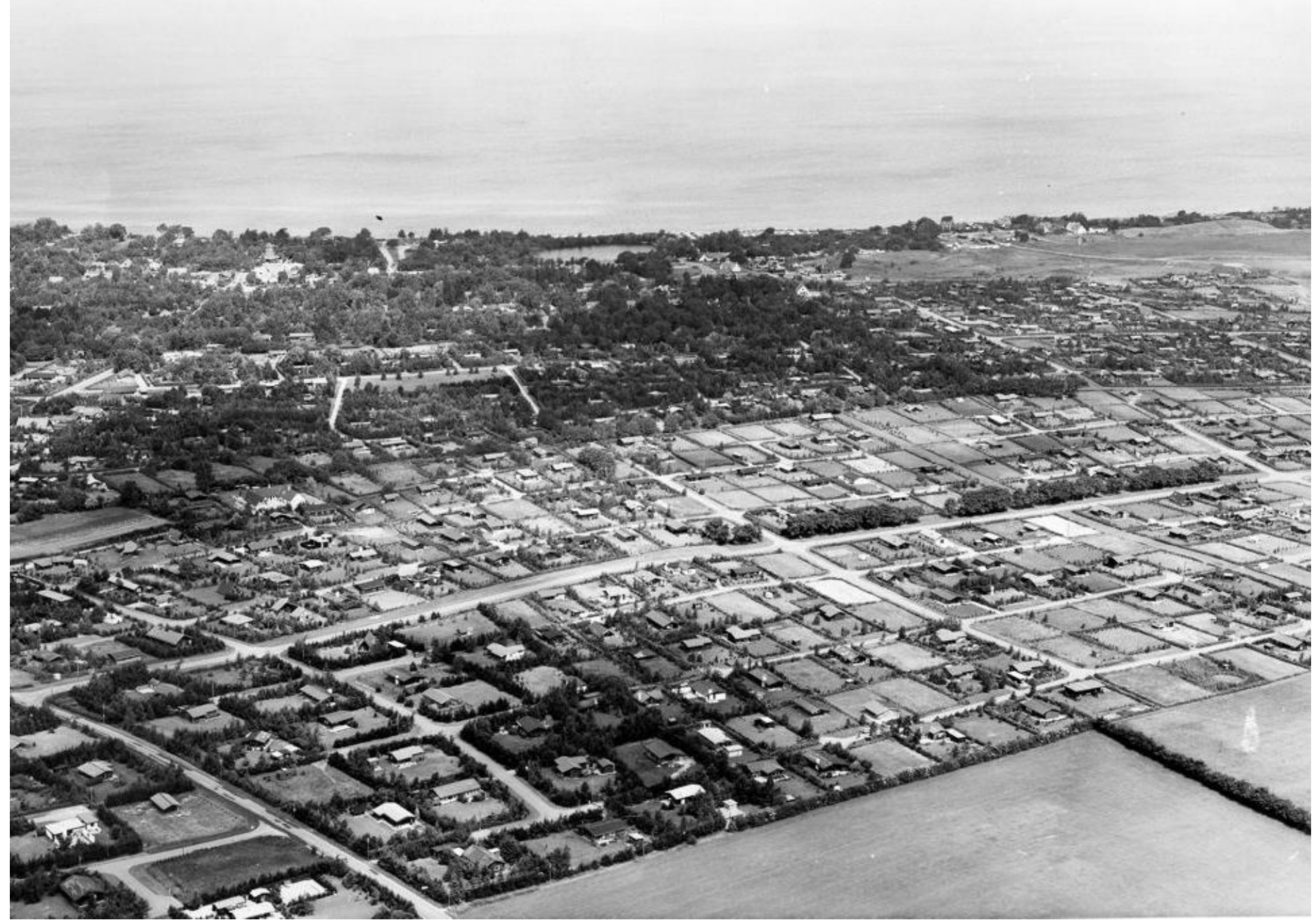

Ikke blot i Kattegatkystens sommmerhusbybæltet, men også $i$ andre af hovedstadsmetropolens øvrige kystnære sommerhusbyer fik bydannelsen et karakteristik forløb. Fra de ældre og ofte også mest mondæne sommerhusbebyggelser langs kyst-, fjorde- og søbreddderne lagde sig langs systemer af stadig mere udbyggede sideog parallelveje tidsmæssigt forskudte koncentriske bebyggelseslag, der førte ind i ballandet. Mønstret kunne tydeligt ses fra luften over sommerhusbyen Dronningmølle i 1968. I billedets forgrund og højre side de senest udstykkede og bebyggede bebyggelselag, hvor beplantningen endnu ikke er vokset til. Herfra mod kysten stadig ældre bebyggelseslag med en stadig mere tæt bebyggelse og beplantning (Gribskov Arkiv). 


\section{Bystruktur}

Da der allerede inden midten af det 20.århundrede var opstået et næsten ubrudt sommerhusbybælte langs den attraktive Kattegatkyst, blev denne tidligere bebyggelse sammen med de givne landskabsforhold bestemmende for formen for og karakteren af efterkrigstidens sommerhusbydannelse i det nordsjællandske kysbælte. På nær plantageområder og arealer, som offentlige myndigheder reserverede af almene rekreative og naturbeskyttende hensyn, dannedes der ved Kattegat et mere en $50 \mathrm{~km}$ langt og 1-6 km bredt sommerhusbælte, der fulgte kystlinjen mellem Helsingør og Tisvildeleje, for herfra at følge østsiden af Tisvilde Hegn og sydsiden af sammen og Asserbo og Liseleje plantager for herfra at forsætte op langs vestiden af sidstnævnte plantage og for fra Liseleje på ny at følge Kattegatkysten frem til Hundested. Trods den meget vidtstrakte og massivt bebyggede karakter, som Kattegatkysten sommerhusbybælte med mere end 21.000 sommerhuse fik i efterkrigstiden, var det ikke i stand til at opsuge det volumen af sommerhuse, der lokaliseredes til området, hvorfor der uden for dette inde i landet opstod tre mere afgrænsede og isolerede sommerhusbyer, der i Stenstrup mod øst og Evetofte og Præstelodden mod vest omfattede mere end 1.000 sommerhuse.

\section{Bebyggelse}

Med de betydelige sommerhusbyer, der allerede inden midten af det 20. århundrede var opstået ved fiskerlejerne Hornbæk, Rågeleje, Tisvildeleje og Liseleje og i Asserbo, disses kraftige udbygning i efterkrigstiden og periodens massive udvidelser af de mellemliggende sommerhusbybælter fra Tinkerup til Holløselund strande kom disse dele af Kattegats sommerhusbybælte til omfatte ni store sommerhusbyer med mere end 1.000 sommerhuse (tabel III.13). Meget store og koncentrerede sommerhusbyer, der ved udgangen af efterkrigstiden rummede næsten 80 procent af sommerhusene i Kattegatkystens sommerhusbybælte. Af disse blev sommerhusbyen Asserbo med næsten 4.000 sommerhuse den største og sommerhusbyen Holløselund Strand med godt 1.100 huse den mindst.

Knapt syv procent af Kattegatkystens sommerhuse blev i efterkrigstiden lokaliseret til sommerhusbybæltes to større sommerhusbyer, Dronningmølle og Vejby Strand, mens ti mellemstore sommerhusbyer omfattede 13 procent kystens sommerhuse. Heraf seks i det relativt mindre bebyggede kystbælte mellem Helsingør og Gilleleje, hvoraf den i baglandet beliggende Stenstrup blev den ene, og fire i det store og tæt bebyggede område mellem Gilleleje og Hundested, hvoraf de i perioden opståede nye sommerhusbyer Evetofte og Præstelodden udgjorde de to. Alene 2 procent af sommerhusbybæltes huse blev lokaliseret til fire mindre sommerhusbyer. Samlet blev efterkrigstidens sommershusbydannelser ved Kattegat kendetegnet af en stærk koncentration af sommerhuse i sommerhusbyer med mere end 200 huse.

Tabel III.13. Procentvis fordeling af sommerhuse efter sommerhusby størrelse ved Kattegatkysten, 1950-1990

\begin{tabular}{|l|l|l|}
\hline & $\begin{array}{l}\text { Procentvis fordeling efter antal } \\
\text { huse }\end{array}$ & Antal sommerhusbyer \\
\hline Store sommerhusbyer (over 1.000 huse) & 78,1 & 9 \\
\hline Støre sommerhusbyer (500-999 huse) & 6,7 & 2 \\
\hline Mellemstore sommerhusbyer (200-499) & 13,2 & 10 \\
\hline Mindre sommerhusbyer (Mindre end 199) & 2,0 & 4 \\
\hline Total & 100 & 25 \\
\hline
\end{tabular}

Kilde: Henvisninger under Appendix VI.A.

Mens de to sommerhusbyer, der i efterkrigstiden opstod i Kattegatkystens bagland dannedes ved bebyggelser ved et system af side og parallelveje til de oprindelige primærbiveje, der løb mellem Halsnæs kyster til Kattegat og Roskilde Fjord, fik byerne i sommerbybæltet en ensartet bebyggelsesudvikling- og struktur. Med udgangspunkt i større eller mindre sommerhusbebyggelser opstået inden midten af det 20. århundrede ved størrelsesmæssigt forskelligartede systemer af side- og parallelveje enten til langs kysten gående lokale strandveje eller op til Hornbæk, Asserbo og Liseleje plantager og Tisvilde Hegn, udbyggedes 
sommerhusbybæltet i efterkrigstiden ud fra disse bebyggelser som tidsmæssigt forskudte koncentriske lang ved nye og mere omfattende systemer af side-, tvær og parallelveje, der stod i forbindelse med den ældre bebyggelses vejsystemer eller udlagdes med tilslutning til gennemgående strand- og landeveje eller til disse fra baglandet førende primær- og sekundærbiveje.

Udover visse større fællesarealer i de to på Halsnæs på bar mark opstående baglandssommerhusbyer og et bebyggelsesopdelende gennemgående fælles areal i de senest udbyggede sommerhusbyer Hald Strand og Hundested Nord, blev bebyggelsen af Kattegatkystens sommerhubybælte så koncentreret, at der i disses enkelte sommerhusbyer stort set ikke udlagdes fællesarealer. Adgang til større udbyggede arealer blev alene tilvejebragt af de stedlige statsligt ejede skov- og plantageområder og de arealer, som offentlige myndigheder havde revserveret for at inddæmme sommerhusbyspredningen af almenrekreative og naturbeskyttende hensyn. ${ }^{25}$

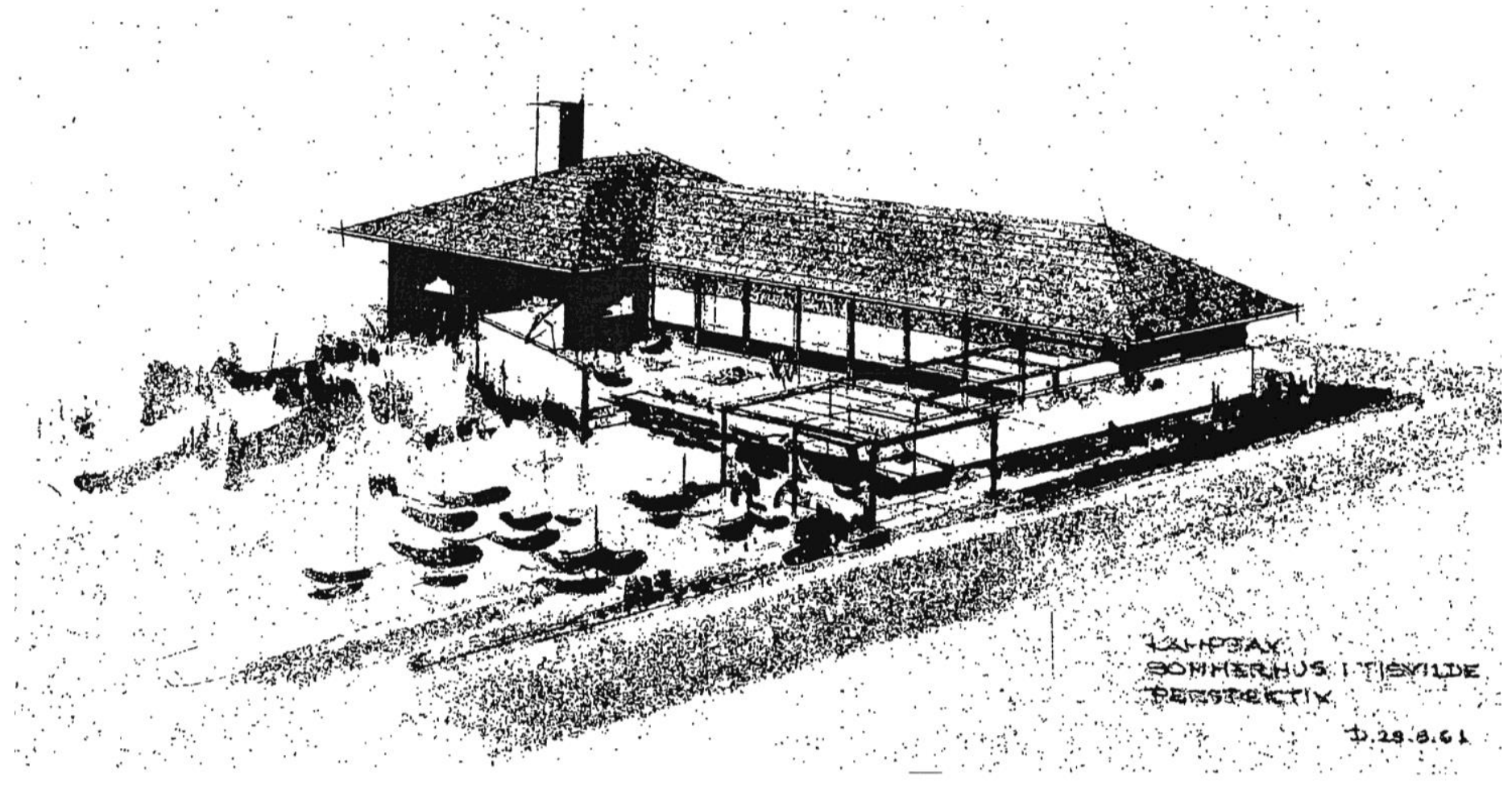

I den særlig eksklusive sommerhusby Rågeleje opførtes i 1961 dette eksorbitant store sommerhus - selvfølgelig arkitekttegnet og beliggende helt ud til kystlinjen (Gribskov Kommune digitale byggesager, https://www.weblager.dk/).

\section{Social sammensætning}

Selv om den sociale sammensætning af førstegangsommerhusejere i Kattegatkystens sommerhusbybæte i den første efterkrigstid ikke blev kendetegnet af de samme ekstreme skævheder som i perioden op til midten af det 20. århundrede, kom den forsat til at skille sig marknat ud $\mathrm{i}$ forhold til hovedstadsmetrolens sommerhusbyer som helhed (tabel III.14). Arbejderklassens andel på under en tidende af denne ejergruppe udgjorde således forsat en signifikant lavere andel ved den nordsjællandske kyst end $\mathrm{i}$ andre af hovedstadsmetropolens sommerhusbyer, hvor andelen lå i nærheden af en femtedel. Samtidig tegnede de højre indkomstlag af større selvstændige og højere funktionærer sig endnu for mere end en tredjedel af førstegangssommerhusejerne ved Kattegatkysten, mod godt en femtedel i metropolens $\varnothing$ vrige sommerhusbyer. Mens andelen af $\varnothing v r i g e$ funktionærer stort set var den samme ved Kattegatkysten som i hovedstadsmetropolens samlede mængde sommerhusbyer, var andelen af mindre selvstændige lavere ved den nordsjællandske kyst. 
Den i forhold til den øvrige hovedstadsmetropol særegne sociale sammensætning af førstegangssommerhusejere i Kattegatkystens sommerhusbyer afspejlede sig også i denne ejergruppes fordeling på bopælsområder i hovedstadsmetropolen og på boligformer (tabel III.15). Mens hovedstadsmetropolens førstegangsommerhusejerne i den første efterkrigstid fordelte sig mere jævnt forhold til den samlede fordeling af metropolens befolkning på dennes forskellige dele og boligformer, havde en signifikant større andel af denne ejergruppe ved den nordsjællandske kyst bopæl i de nordlige velhaverforstæder og i et enfamiliehus.

Sammenhægen mellem bopælsområder og boligformer for hovedstadsmetropolens højeste placerede samfundslag og den geografiske lokaliseringen af sammes sommerboliger forblev således intakt i efterkrigstiden.

Tabel III.14. Procentvis social sammensætning af førstegangssommerhusejere ved Kattegatkysten, 1974-1990 og erhvervsbeskæftigede i hovedstadsmetropolen, 1950 og 1970.

\begin{tabular}{|c|c|c|c|c|c|c|}
\hline \multirow[t]{3}{*}{ Stilling } & \multirow{3}{*}{\multicolumn{2}{|c|}{$\begin{array}{l}\text { Sommerhusejere, } \\
1950-1973\end{array}$}} & \multicolumn{4}{|c|}{$\begin{array}{l}\text { Hovedstadsmetropolens erhvervsbeskæftigede } \\
\text { Befolkning }\end{array}$} \\
\hline & & & \multicolumn{2}{|c|}{1950} & \multicolumn{2}{|c|}{1970} \\
\hline & & & Hovedstaden & Forstæder & Hovedstaden & Forstæder \\
\hline Større selvstændige & 11,9 & & & & & \\
\hline Mindre selvstændige & 11,8 & & & & & \\
\hline Selvstændige, total & & 23,7 & 11,7 & 17,4 & 7,1 & 9,5 \\
\hline Ledende funktionærer & 8,8 & & & & & \\
\hline Akademisk uddannede funktionærer & 13,9 & & & & & \\
\hline Højere funktionærer, i alt & 22,7 & & & & & \\
\hline$\varnothing$ vrige funktionærer & 43,9 & & & & & \\
\hline Funktionærer, total & & 66,6 & 33,0 & 24,2 & 42,6 & 44,6 \\
\hline Faglærte arbejdere & 8,7 & & & & & \\
\hline Ufaglærte arbejdere & 1,0 & & & & & \\
\hline Arbejdere, total & & 9,7 & 53,3 & 58,4 & 50,0 & 44,1 \\
\hline Total & 100 & 100 & 100 & 100 & 100 & 100 \\
\hline
\end{tabular}

Kilde: Henvisninger under Appendix VI.A. Bro: Hovedstadsmetropolen- den danske byregion, 2020, s. 547-548.

Selv om Kattegatkystens sommerhusbybælte som helhed også i den første efterkrigstid blev et regionalt fritidsbosætningsområde for hovedstadsmetropolens højeste indkomstlag, og den sociale sammensætning af førstegangssommerhusejere var ganske homogen gennem perioden, dækkede det dog over visse mindre variationer i de enkelte sommerhusbyer. Mens segmentet af større selvstændige og højere funktionærer, der samtidig i meget udtalt grad havde bopæl i hovedstadsmetropolens nordlige velhaverforstæder og her beboede enfamiliehuse, var særlig fremherskende i sommerhusbyerne omkring fiskerlejerne og på kyststrækningerne Tinkerup Strand-Udsholt Strand og Valby Strand-Holløse Strand, blev noget lavere indkomstlag i højere grad repræsenteret som førstegangssommerhusejere på strækningen Dronningmølle-Nakkehoved, i Asserbo og de to sommerhusbyer, Evetofte og Præstelodden, som var opstået i den første efterkrigstid samt i sommerhusbyen Stenstrup, som i helt overvejende grad blev bebygget i denne periode.

Tabel III.15. Procentvis fordeling af bopælsområde og boligform for førstegangssommerhusejere ved Kattegatkysten, 19501973, og i hovedstadsmetropolen, 1950 og 1970.

\begin{tabular}{|l|l|l|l|}
\hline & Sommerhusejere & \multicolumn{2}{l|}{ Hele hovedstadsmetropolens befolkning } \\
\hline Bopæl i: & $1950-1973$ & 1950 & 1970 \\
\hline Hovedstaden & 42,9 & 61,9 & 41,8 \\
\hline Nordegnen & 36,7 & 12,2 & 13,5 \\
\hline Nordvestegnen & 13,3 & 3,8 & 8,5 \\
\hline Vestegnen & 4,3 & 7,0 & 15,4 \\
\hline Andet & 2,8 & 15,1 & 20,8 \\
\hline Total & 100 & 100 & 100 \\
\hline Etagebolig & 50,4 & 82,3 & 74,7 \\
\hline Enfamiliehuse & 49,6 & 17,7 & 25,3 \\
\hline Total & 100 & 100 & 100 \\
\hline
\end{tabular}

Anm: Fordelingen på etageboliger og enfamiliehuse omfatter alene hovedstaden og forstadsegnene

Kilde: Henvisninger under Appendix VI.A. Statistiske Årbog for København, Frederiksberg m.m., 1952, s. 1, 55, 191-

192 og 198. https://www.kk.dk/sites/default/files/migrated/sc/1972-aarbog.pdf

https://www.kk.dk/sites/default/files/migrated/sc/1975-aarbog.pdf 
Her udgjorde arbejderklassen og laget af øvrige funktionærer og mindre selvstændige således en højere andel blandt førstegangssommerhusejerne end i Kattegatkystens sommerhubyer i gennemsnit. En social sammensætning, der også afspejledes sig i ejerggruppens hjemlige bopæls- og boligforhold. En væsentligt større del af denne gruppe beboede således en lejlighed i en etagebebyggelse og havde bopæl i hovedstaden og forstæderne på Nordvest- og Vestegnen.

Den sociale sammensætning i disse efterkrigstidssommerhusbyer ved Kattegatkysten, var betinget af de lavere grundpriser, som fulgte af disses placering længere inde i kystbaglandet. Sommerhusbyerne på strækningen Dronningmølle-Nakkehoved havde ganske vist en særdeles kystnær beliggenhed, men den større afstand til fiskerlejerne Hornbæk og Gilleleje og kystens skovbeplantning og skrænter, gjorde antagelig strækningens tre sommerhusbyer mindre tiltrækkende. Allerede inden midten af det 20. århundrede havde mellemlaget af øvrige funktionærer og mindre selvstændige udgjort en større andel af førstegangssommerhusejerne i disse sommerhusbyer, der hverken på dette tidspunkt eller senere i samme omfang fik de overklasseattraktioner, som i form af restauranter, badehoteller, pensionater og kurbadeanstalter særlig kendetegnede fiskerlejerne og disses omgivende sommerhusbyer. Lokale forhold, der også gjorde sig gældende i den store sommerhusby Asserbo, som samtidig lå et godt stykke inde i kystbaglandet, og dermed også fik en mere jævn social sammensætning af førstegangssommerhusejere. ${ }^{26}$
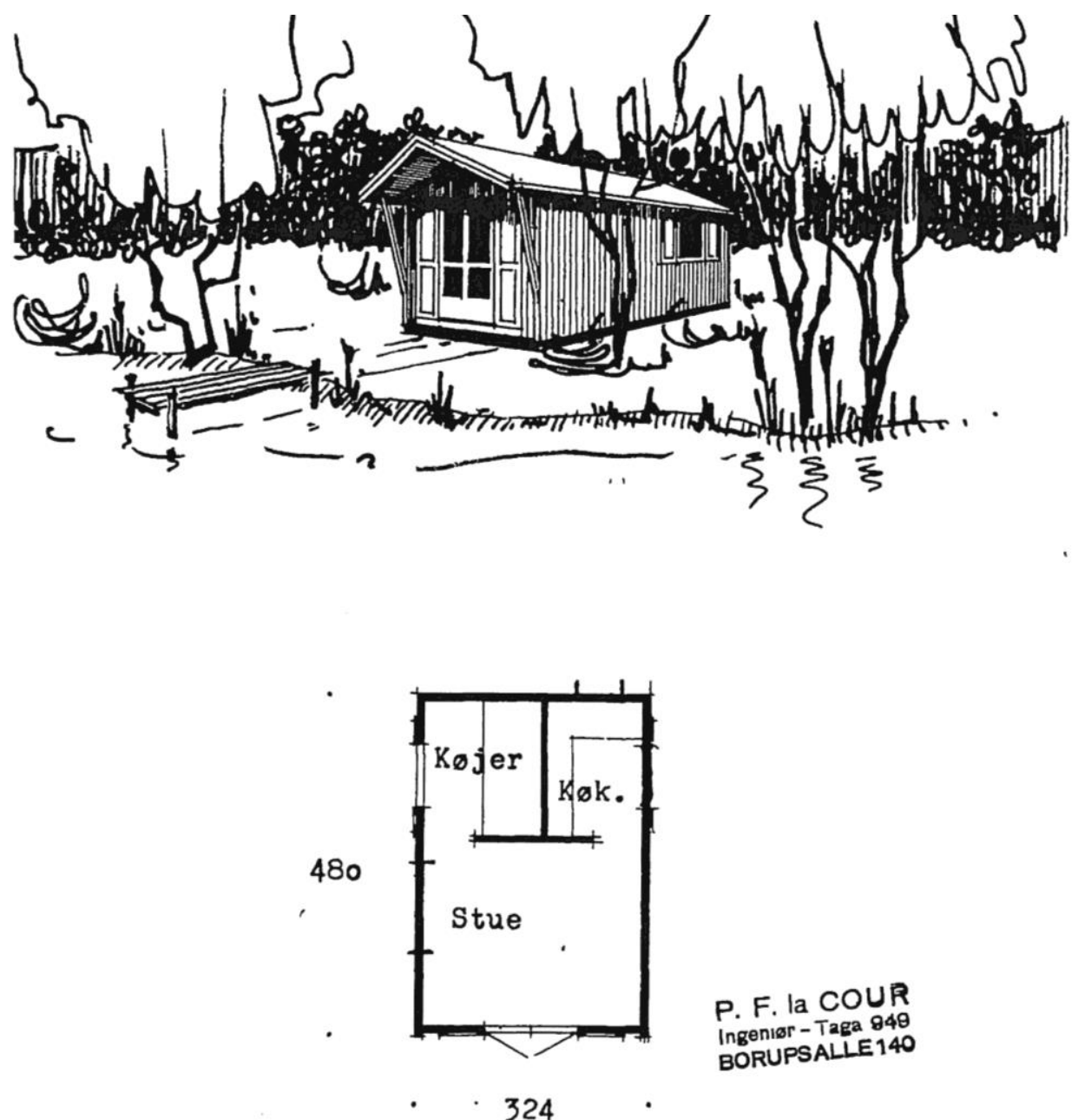

P. F. la COUR Ingeniør - Taga 949 BORUPSALLE140

I forhold til det øvrige nordsjællandske sommerhusbybælte blev den sociale sammensætning i sommerhusbyen Asserbo mere jævn. Det blev da ogsa her, hvor typesommerhuse blev mere udbredt end på de øvrige dele af Kattegatkysten. Blandt i form af dette lille Skarridsø Hus fra 1957 (APPENDIX IX og Gribskov Kommune digitale byggesager, https://www.weblager.dk/). 


\section{Sommerhusstandard}

Selv om den første efterkrigstids sommerhuse i Kattegatkystens sommerhusbyælte ikke fik samme ekstravagante karakter, som dem der her var blevet opført før midten af det 20. århundrede, skilte de sig stadig markant ud fra sommerhusstandarden i hovedstadsmetropolens sommerhusbyer som helhed. Sommerhusbybæltes særegne sociale sammensætning af førstegangssommerhusejerne, der var en følge af de særligt høje grundpriser ved Kattegatkysten, satte sig således også igennem i den karakter, som sommerhusene fik her (tabel III.16 og APPENDIX VI.A).

En langt større andel af var således opført med arkitektbistand, hvorimod selvbyg indgik med en beskeden antal. Andelen af sommerhuse ved Kattegatkysten, der var opført af hăndværksmestre, udgjorde tilsvarende en langt mindre andel end i samtlige af hovedstadsmetropolens sommerhusbyer, der tillige havde en noget højere andel af typesommerhuse end i det nordsjællandske sommerhusbybælte; jf. APPENDIX VIII. Blandt disse udgjorde de dyrere huse fra Myresjø Huse, Skarridsø Huse og Västkust Stugan den største andel blandt de ti mest udbredte mest udbredte typesommerhuse i Kattegatkysten sommerhusbybælte, som også talte de dyreste sommerhuse fra Safarihuset og Smidstrup Huset (tabel III.17). Til gengæld indgik de billigere typesommerhushuse, som navnlig husene fra Jeppesens Savværk, Ganløse Huset og Tårnby Huset repræsenterede, med en lavere andel i de nordsjællandske sommerhusbyer, hvor det samtidig var langt mindre udbredt at opføre et skur til kortvarigt ophold og opbevaring af haveredskaber og værktøj inden, der blev tilvejebragt midler til opførelse af et egentligt sommerhus.

\begin{tabular}{|c|c|c|c|c|c|}
\hline \multirow{2}{*}{ Opført, i procent: } & Som selvbyg & Af bygmester & Med arkitektbistand & Af byggefirma & Total \\
\hline & 5,3 & 18,0 & 24,5 & 52,2 & 100 \\
\hline \multicolumn{6}{|c|}{ Rumfordeling, i procent: } \\
\hline 1 rum & 2 rum & 3 rum & 4 rum & 5 el. fl. Rum & Total \\
\hline 0,4 & 12,9 & 50,1 & 23,6 & 13,8 & 100 \\
\hline \multirow[t]{2}{*}{ Toilet, i procent: } & Udenfor huset & I huset & Total & \multirow{2}{*}{\multicolumn{2}{|c|}{$\begin{array}{l}61,9 \text { procent med bad. } \\
0,1 \text { procent uden køkken }\end{array}$}} \\
\hline & 11,7 & 88,3 & 100 & & \\
\hline Areal: & \multicolumn{2}{|c|}{ Mellem $15-190 \mathrm{~m}^{2}$.I gennemsnit $60,6 \mathrm{~m}^{2}$} & Udvidelser: & \multicolumn{2}{|c|}{ I gennemsnit $\times \mathrm{m}^{2} 15,2$} \\
\hline \multicolumn{3}{|c|}{ Opført, procentfordeling: } & \multicolumn{3}{|c|}{ Forsynet, procentfordeling: } \\
\hline Af træ & Som grundmuret & Total & Med skorsten & Uden skorsten & Total \\
\hline 84,4 & 15,6 & 100 & 71,0 & 29, & 100 \\
\hline \multicolumn{2}{|c|}{ Opført på, procentfordeling: } & \multicolumn{2}{|c|}{ Vandforsyning, procentfordeling: } & \multicolumn{2}{|c|}{ Spildevandsafledning, procentfordeling: } \\
\hline Piller & Fundament & Udenfor hus & I hus & Ingen & Sivebrønd m.m. \\
\hline 6,7 & 93,3 & 4,2 & 95,8 & 3,9 & 96,1 \\
\hline
\end{tabular}

Kilde: Henvisninger under Appendix VI.A.

Disse indikatorer for en signifikant højre standard af sommerhusene i Kattegatkysten sommerhusbybælte understøttes af disses størrelse. Mens sommerhusene i hovedstadsmetropolens sommerhusbyer som helhed havde et gennemsnitareal på $51,9 \mathrm{~m}^{2}$ og i 75,5 og 22,5 procent af tilfældene rummede 2-3 og 4-5 værelser, var gennemsnitarealet på 60,6 $\mathrm{m}^{2}$ i de kystnære nordsjællandske sommerhuse, der for 63 og 37 procents vedkommende omfatte huse med 2-3 og 4-5 værelser. En større andel var opført på et støbt fundament, og mere end tre fjerdedele var fuldisolerede, ligesom den opvarmningsform som en skorsten gav var langt mere udbredt. For så vidt de faciliteter, som sommerhusene var udrustet med, blev Kattegatkystens sommerhusbælte de bedst udstyrede. Ikke mindre end henholdsvis 88 og 62 procent af sommerhusene var her, i modsætning til 81 og 42 procent i hovedstadsmetropolens sommerhusbyer som helhed, udruste med toilet og bad i huset. Andel af sommerhuse uden indlagt vand og spildevandsafledning var desuden forsvindende.

Ligesom der var visse variationer i sammensætningen af den første efterkrigstids førstegangssommerhusejer i Kattegatkystens sommerhusbybælte, gjaldt det også kvaliteten af dets sommerhuse. Mens sommerhusene i sommerhusbyerne ved fiskerlejerne og på strækningerne Tinkerup Strand-Udsholt Strand og Vejby Strand-Holløselund Strand lå højere på de gennemsnitlige standardmål for sommerhuskvaliteten i nordsjællandske sommerusbybælte, placerede de tre efterkrigssommerhusbyer og sommerhusbyerne på strækningen Dronningmølle-Nakkehoved sig under disse talstørrelser. 
Sommerhuse opført af bygmestre uden arkitektbistand og typesommerhus, og særlige dem i den billigere kategori fra Jeppesens Savværk, Ganløse Huset og Skovhusene, var således relativt mere udbredt i disse sommerhusbyer, hvor sommerhusene arealmæssigt lå under det nordsjællandske gennemsnit og rummede flere med et, to og tre rum. En større andel af disse sommer sommerhuse var ikke udrustet med toilet huset, bad, den opvarmningsmulighed en skorsten gav, og var opført som træbygninger uden fuldisolering. Endelig var det langt mere almindeligt i disse sommerhusbyer at opføre et skur inden, der rejstes et egentligt sommerhus på grunden.

Tabel III.17. Procentvis fordeling af de ti største producenter af sommertypehuse ved Kattegatkysten, $1950-1973$.

\begin{tabular}{|l|l|}
\hline Myresjö Huse & 22,6 \\
\hline Skarrids $\varnothing$ Huse & 17,2 \\
\hline Västkust Stugan & 13,5 \\
\hline Jeppesens Savværk & 11,8 \\
\hline Safarihuset & 5,1 \\
\hline Tectum & 3,7 \\
\hline Ganløse Huset & 2,4 \\
\hline Fribo Hus & 2,3 \\
\hline Smidstrup Huset & 2,0 \\
\hline Tårnby Huset & 1,7 \\
\hline Andre & 17,7 \\
\hline Total & 100 \\
\hline
\end{tabular}

Anm.: Andre producenter omfatter xx virksomheder. Kilde: Henvisninger under Appendix VI.A.

Ligesom den første efterkrigstids sociale sammensætning af førstegangssommerhusejere var mere jævn i Asserbo, gjaldt det også de standardmål, der kendetegnede denne sommerhusby. Måltallene for kvaliteten af sommerhuse i Asserbo lagde sig således nogenlunde på de gennemsnitlige talstørrelser for sommerhusstanden i Kattegatkysten sommerhusbyer, dog således at sommerhusene i denne sommerhusby var mindre end gennemsnittet, og rummede en større andel af huse uden toilet i huset, bad, skorsten og fuldisolering. ${ }^{27}$

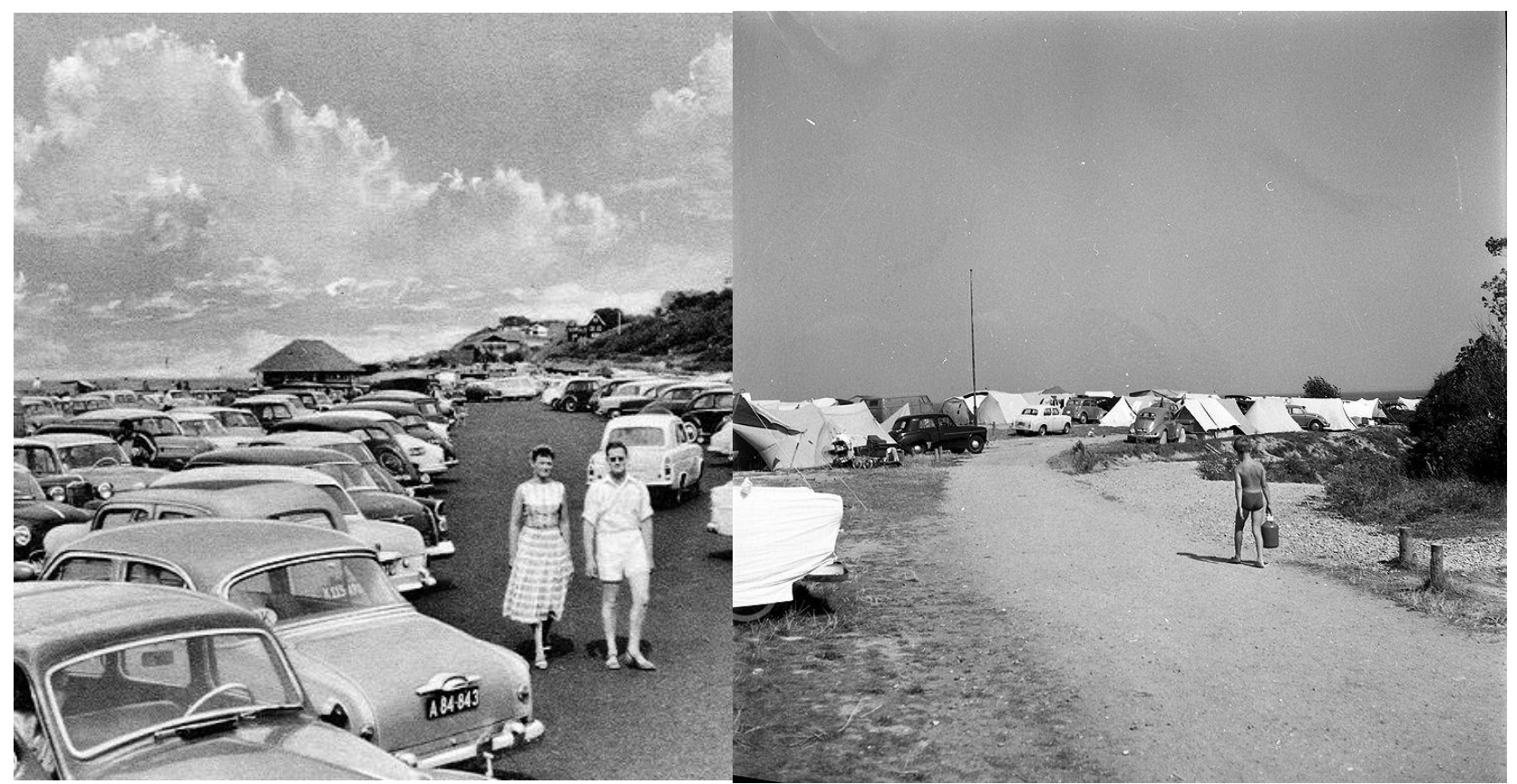

I efterkrigstiden kunne sommerhusbybæltet ved Kattegatkysten ikke fastholdes som et eksklusivt sommerland for hovedstadsmetropolens overklasse. Med den stadig mere udbredte privatbilisme blandede fremmedelementer sig $i$ idylen. I form af: De store folkemængder, der søgte til kystens badestande; til venstre: Parkringspladsen ved stranden ved Tisvildeleje en gang i midten af 50 'erne. Eller det støre antal campingpladser, der samtidig etableredes $i$ den tidligere nordsjællandske overklasseenklave; til højre Dronningmølle Campingplads i 1960 (Gribskov Arkiv). 


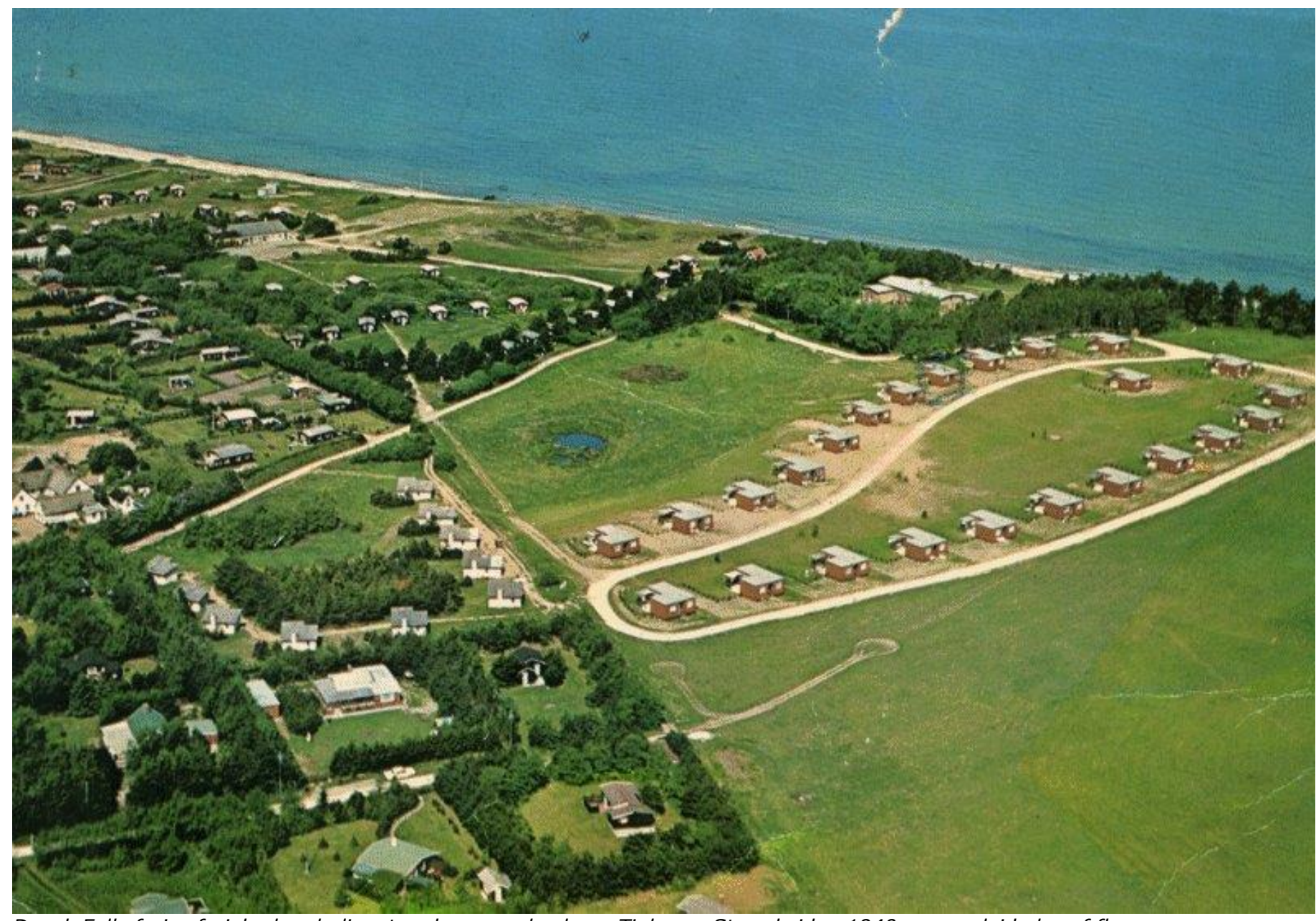

Dansk Folkeferies ferieby havde ligget ved sommerhusbyen Tinkerup Strand siden 1940, men udvidedes af flere omgange. Nok ikke til udelt begejstring for de såkaldt "pæne mennesker" i de omliggende sommerhuse. (Luftfoto, 1965, Gribskov Arkiv)

\section{Forsyning}

Allerede inden midten af det 20. århundrede havde NESA varetaget elektricitetsforsyningen af sommerhusbybæltet ved Kattegatlysten, og kom også til at stå for denne forsyningsopgave i takt med dettes udbygning i efterkrigstiden. Da der ved kystens fiskerlejer og i Asserbo inden midten af det 20. århundrede var etableret kommunale eller private vandværk, der tillige forsynede de tilstødende sommerhusbyer, blev disse værkers forsyningsnet udvidet i takt med disse sommerhusbyers udbygning.

Mens mere end halvdelen af sommerhusbyerne således kunne basere vandforsyningen på eksisterende produktionsværker, var der ved midten af århundredet endnu ikke blevet etableret vandværker i de den gang smalle sommerhusbybælter på kyststrækningerne Villingebæk-Munkerup, Tinkerup Strand-Udsholt Strand og Vejby Strand-Holløselund Strand, hvor vandforsyningen tilvejebragtes ved boringer på de enkelte grunde og med anvendelse af mere eller mindre avancererede oppumpningsanlæg.

For her at sikre vandforsyningen i takt med disse sommerhusbyer kraftige udbygning i efterkrigstiden etablerede grundejerforeningerne på førstnævnte kyststrækning et fælles vandværk i Villingebæk, mens vandproduktionen på de to øvrige strækninger blev overladt til de stedlige sognekommuner. I sommerhusbyerne Stenstrup, der ved midten af det 20 . århundrede alene var bebygget $i$ et beskeden omfang og Evetofte og Præstelodden, som først 
opstod i efterkrigstiden, blev etableringen af de nødvendige mindre vandværker overladt til de stedlige grundejerforeninger.

Skønt inden midten af det 20. århundrede var gennemført kloakering i de indre dele af Hornbæk, Gilleleje og Hundested, blev disse spildevandsafledningssystemer ikke ført ud i de tilstødende sommerhusbyer. Selv om der omkring 1960 indledtes en kloakering i

sommerhusbyerne omkring Hornbæk, blev det således først i perioden 1969-1978, at denne proces påbegyndtes $i$ en betydelig del af Kattegatkysten sommerhusbælte. Sammen med de tidligere kloakerede sommerhusbyer kom denne omfattede kloakering efterhånden til at omfatte tre fjerdedele af sommerhusene i Kattegatkystens sommerhusbybælte. Alene i sommerbyerne i Asserbo og på Halsnæs forblev spildevandsafledningen baseret på sivebrønde og septiktanke, og da alene fire procent af sommerhusbæltes sommerhuse ikke tilsluttedes sådanne anlæg, opnåedes her efter samtidens standarder rimelige spildevandsafledningsløsninger. ${ }^{28}$

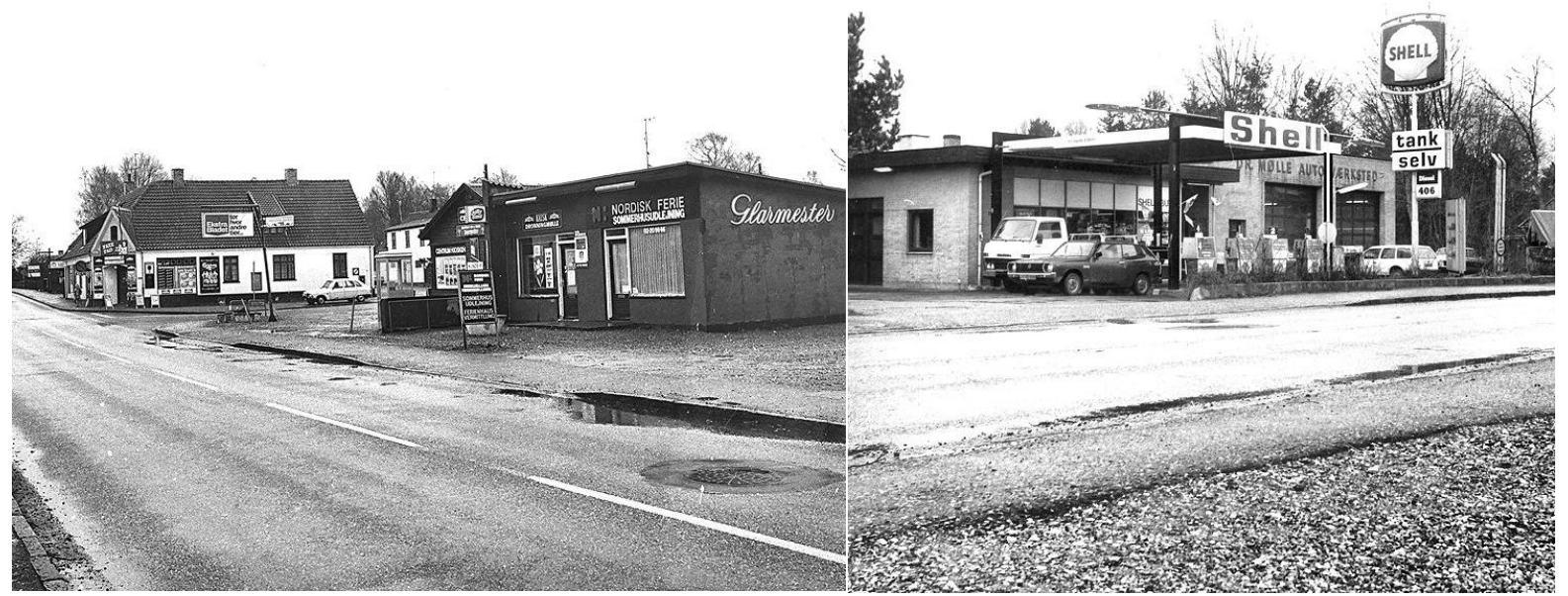

I de sommerhusbyer, der la i større afstand fra de store fiskerlejer og stationsbyer ved Kattegatkysten, opstod der $i$ efterkrigstiden en egentlig erhvervsudvikling som her i Dronningmølle en gang i slut 70 'erne med flere forretninger, benzintank og autoværksted (Gribskov Arkiv)

\section{Erhverv}

Mens fiskerlejerne og nogle af landsbyerne i baglandet inden midten af det 20. århundrede dækkede det behov for dagligvare og håndværksmæssige ydelser, som udgik fra Kattegatkysten sommerhusbybælte, kunne disse byer i takt med efterkrigstidens byerhvervsmæssige tilvækst og differentiering forsatte dække dette behov i den del af kystbæltets sommerhusbyer, som omfattede 60 procent af dettes sommerhuse.

I de resterende del af efterkrigstidens sommerhusbyer ved Kattegatkysten skabte efterkrigstiden imidlertid grundlag for en byerhvervsmæssig udvikling. I den store sommerhusby Horneby Sand, syd for Hornbæk, opstod således en række mindre dagligvareforretninger langs den gennemgående strandvej og i sommerhusbyens sydlige del et supermarked med benzintank. Den byerhvervsmæssige udvikling blev dog mest udtalt i de store sommerhusbyer, der lå i større afstand fra fiskerlejerne.

I Dronningmølle i sommerhusbybæltet mellem Hornbæk og Gilleleje opstod ved den gennemgående strandvej og det bagvedliggende stationsområde: Bageri, ismejeri, slagterforretning, flere købmandshandler, tømrer- og snedkerværksted, autoværksted, VVS- 
virksomhed, autolakereri, cykelforretning, keramisk værksted og udsalg, cafeteria, resturent, flere iskageudsalg, grill, motel og diskotek.

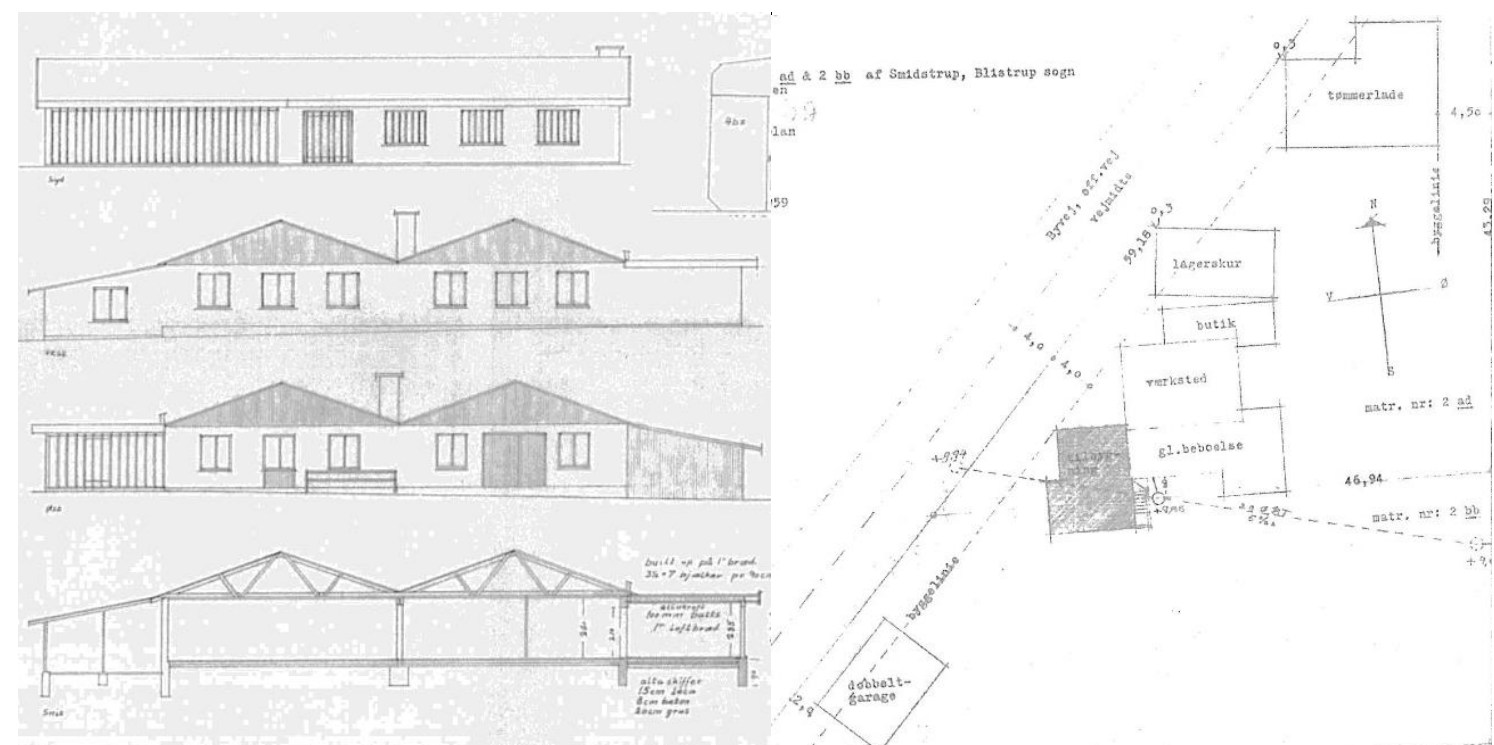

I de af Kattegatkystens sommerhusbyer, hvor der udfoldede sig en større erhvervsudvikling, opstod ofte også forskellige virksomheder inden for bygge- og anlægssektoren. Bl.a. i Smidstrup Strand, hvor planen fra 1960 for en stor tømmerhandel ses til højre og produktionshallerne i 1970 for en betydelig tømrer- og snedkervirksomhed ses til vestre (Gribskov Kommune digitale byggesager, https://www.weblager.dk/).

I sommerhusbybæltet på kyststrækningen Tinkerup Strand-Udsholt Strand opstod på samme tidspunkt: Seks købmandsforretning, et større tømrer- og snedkerfirma, et mindre tømmerfirma, to VVS-firmaer, tømmerhandel, der senere omdannedes byggemarked, en vognmandsforretning, et entreprenør- og byggefirma, som fra 1963 producerede typesommerhuset Smidstrup Huset, indtil dette 1983 fik en ny ejer samt to griller, cafeteriaer og pølse- og iskiosker

I sommerhusbyen Asserbo ligeledes i samme periode: Tre købmandsforretninger, et supermarked, en bagerforretning, en slagterforretning, en mælkehandel, en grillbar, fem ispølsekiosker, et cafeteria, en restaurant, et autoværksted, en benzintank, en vognmandsforretning, en tømmerhandel, en planeskole, to tømrerfirmaer, en VVS-virksomhed og et cementstøberi.

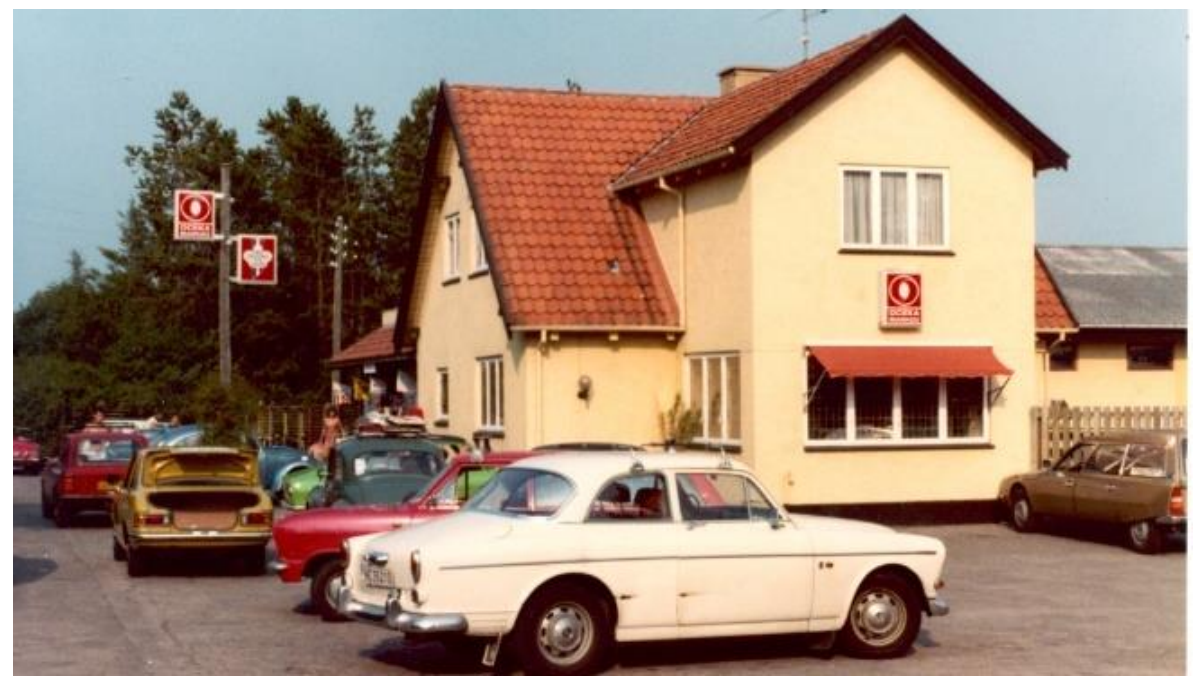

I de sommerhusbyer ved Kattegatkysten, hvor der ikke skete en større erhvervsudvikling, etableredes ofte en eller flere købmandsforretninger, som her i Vejby Strand i 1978 (Gribskov Arkiv) 
Ud over de af Kattegatkysten badehoteller, pensionater og kurbadeanstalter, der i en del af efterkrigstiden kunne forsætte virksomheden og de flere ferie- og hvilehjem, der kom til, gav velfærdstatens rekreative og naturbeskyttende arealdispositioner yderlige erhvervsmuligheder for kystens sommerhusbyer. Som følge af det sociale fremmedelement, der tog ferieophold på de syv campingpladser, som i perioden opstod på offentligt erhvervede arealer. Eller på tilsvarende arealer: Dels Dansk Folkeferies feriecenter ved Tinkerup Strand, der med hyttekoloni var oprettet 1941 og siden udvidedes senest i starten af 80 'erne. Dels den koloni af feriehuse, som Kartonage og papirarbejdernes Fagforening etablerede ved Hald Strand. ${ }^{29}$ 


\section{Sommerhusbyerne i Roskilde Fjord-bæltet}

Da ejendomspriserne allerede i mellemkrigstiden og 40'erne var kommet op på et højt niveau ved Kattegatkysten, og dette yderlige forøgedes med udfyldningen af kystens massivt udbyggede sommerhusbybælte op gennem den første efterkrigstid, førte periodens sommerhusboom til nye sommerhusbydannelser andre steder i hovedstadsmetropolens åbne opland. I første omgang til kystbæltet på den sydlige del af Halsnæs og langs Roskilde Fjords østside, hvor der trods den kortere afstand til hovedstadsmetropolens centrale dele i midten af det 20. århundrede endnu henlå meget omfattende ubebyggede kystområder; jf. Appendix VI.B.

\section{Lokalisering}

Roskilde Fjord nordlige og østlige kystbælte strakte sig over en $50 \mathrm{~km}$ lang kyslinje med et bagland, der omfattede den sydlige del af Halsnæs og området fra Frederiksværk i nord til Roskilde i syd. I modsætning til Kattegatkysten og dens bagland blev kystbæltet op gennem den første halvdel af det 20 . århundrede stort set ikke omfattet af landliggerbosætning og sommerhusbydannelser, men undergik til gengæld en udvikling, der svarede både til den $\varnothing v$ rige danske provins, og på samme tid var under indflydelse af hovedstadsmetropolens nærhed. En udvikling, der med byvækst i købstæder og stations- og landevejsbyer og med eksisterende og gradvist forbedrede trafiklinjer gjorde kystbæltet til en af hovedstadsmetropolens randområder, og samtidig her skabte forudsætninger for en række metropolens sommerhusbydannelser $\mathrm{i}$ efterkrigstiden.

\section{Roskilde Fjord-bæltet - et randområde i hovedstadsmetropolen}

Ved indgangen til det 20. århundrede havde kystbæltet langs den nordlige og østlige del af Roskilde Fjord gennem det forrige århundrede være kendetegnet af kulturhistoriske udviklingstræk, der stort set svarede til den øvrige provins. Bæltet omfattede således tre købstæder, der havde været omfattet af periodens industrialiserings- og urbaniseringsproces, fremvoksende stationsbyer og ellers landdistrikter med kirkesognelandsbyer, underliggende landsbyer og fra årene omkring år 1800 udskiftede og udflyttede selvejergårde.

\section{Halsnæs}

Fra hidtil at have været en fjern udkant i Nordsjælland med sådanne landsbydannelser i indlandet og fiskerlejer ved kysten undergik Halsnæs betydelige forandringer op gennem den første halvdel af det 20. århundrede. Halsnæs havde i forvejen landevejsforbindelse til Frederiksværk og derfra videre til Helsingør, Hillerød og Frederikssund og med forlængelse af Hillerød-Frederiksværk Banen til Hundested i 1916 og den forøgede private rutebilstrafik fra 20 'erne, fik halvøen stærkt forbedrede trafikforbindelser til de mere centrale dele af Nordsjælland og selve hovedstadsmetropolen. Halvøens nordlige del kom dermed til at indgå i mellemkrigstidens og 40'ernes sommerhusbydannelser langs Kattegatkysten, og Hundested ekspanderede yderlige og voksede sammen med det syd for liggende oprindelige fikserleje Lynæs. Den derved langstrakte stationsby havde på denne baggrund i 1950 opnået en samlet befolkning på 2.900 indbyggere, svarende til en tredobling siden 1911 , baseret på en i samme periode nidobling af beskæftigede inden for industri-håndværk og en ottedobling i de servicebaserede fag.

En ekspansiv bymæssig erhvervsudvikling, der ud over fiskeriet, i begyndelsen af perioden hvilede på en konserves- og maskinfabrik og damskibsforbindelse til Grenå, men som senere understøttedes af etablering af fiskeribaserede industrivirksomheder inden for motor- og bådbygning, stålmontage, hermetikproduktion, net-, is- og fiskefodermelsfremstilling samt røgerivirksomhed. Herudover muliggjorde flere havneudvidelser, at damskibsruten til Grenå blev omdannet til en bilfærgerute, og der etableredes bilfærgeforbindelse til Rørvig i 
Odsherred. Med den ganske betydelige størrelse Hundested opnåede, blev stationsbyen, udover kommunale institutioner som alderdomshjem og skole med mellem-og realklasser, i kraft af sin kystnærhed i den første halvdel af det 20. ărhundrede hjemsted for et rekreationshjem for småbørn, flere sommerkolonier og ferielejre samt et vandrehjem.

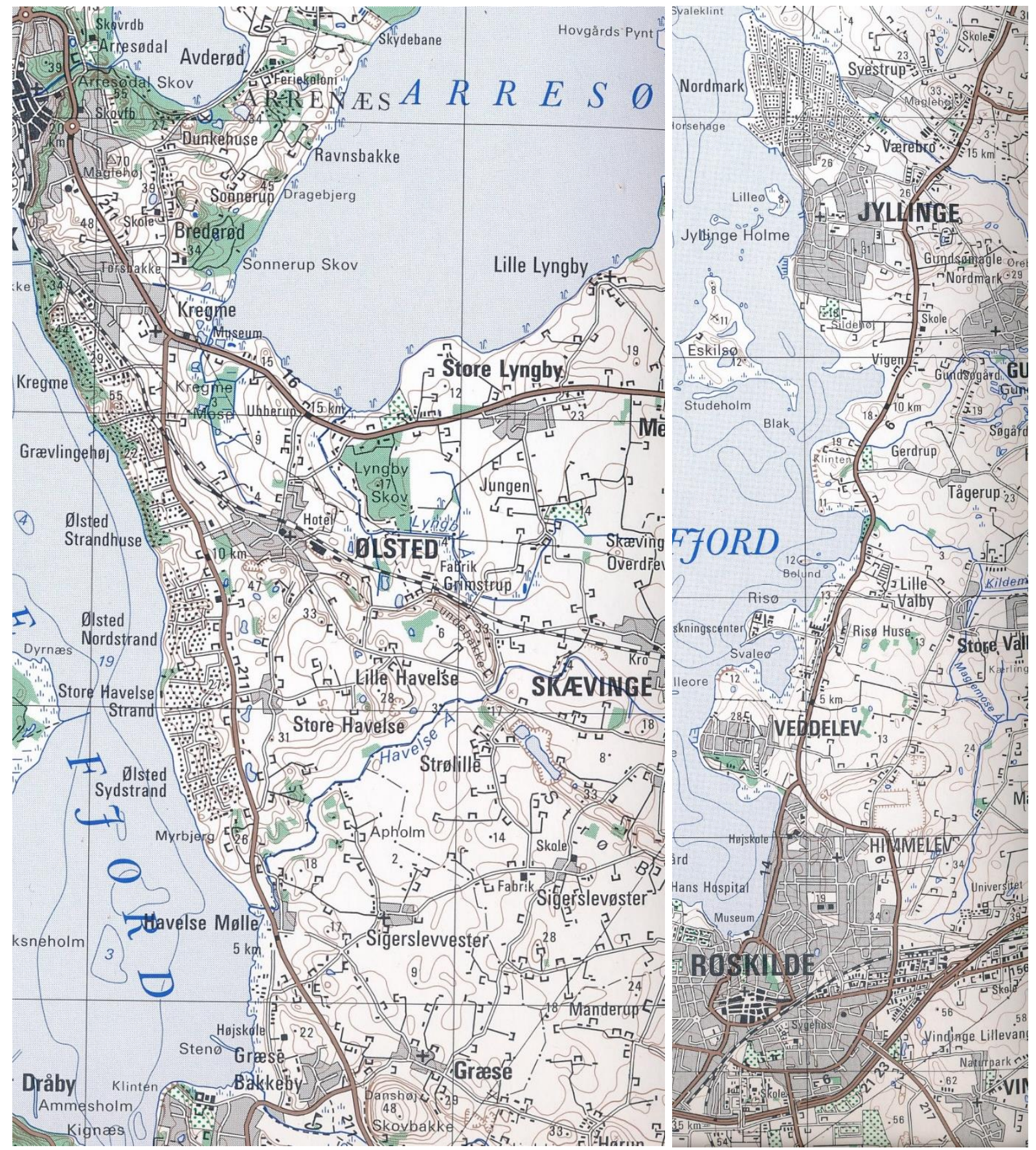

Sommerhusbybæltet ved Roskilde Fjords nord- og østside. Til venstre: Bæltet: Frederiksværk-Frederikssund. Til højre: Bæltet: Frederikssund-Roskilde. Halsnæsdelen, se kort i Kapitel 3. (Danmark 1:100.000, Geodætisk Institut, 2000)

Var Halsnæs som helhed frem til midten af århundredet blevet stadig mere integreret med det $\varnothing$ vrige Nordsjælland og dermed med hovedstadsmetropolen opland, var periodens erhvervsog bebyggelsesmæssige forandringer slået mindre igennem på halvøens sydside mod Roskilde Fjord. Pă nær spredte sommerhusbebyggelser blev denne del af halvøen i peioden forsat kendetegnet af ældre spredte bebyggelser i form af fiskerlejer, mindre landsbyer og 
husklynger i de egentlige landdistrikter og betydelige inddigede engstrækninger ned mod Roskilde Fjord. ${ }^{30}$

\section{Kystbæltet: Frederiksværk-Frederikssund}

I den bugt, der dannedes af Halsnæs og det øvrige Nordsjælland var Frederiksværk i løbet af 1700-tallet opstået på grundlag af merkantilistiske fabriksanlæg, som delvist fra midten af det 19. århundrede forsatte på et almindeligt industrikapitalistisk grundlag med en produktion, der efterhånden kom til at omfatte handels- og bygningsstøbegods, emaljerede gryder, kakkelovne og komfurer. På dette grundlag og etableringen af jernbaneforbindelsen til Hillerød i 1897 opstod flere håndværksvirksomheder, mindre industri og egentlig detailhandel, der bidrog til fordobling af Frederiksværks befolkningstal op gennem århundredets sidste halvdel.

En urbaniseringsproces, der bevirkede, at byen tidligt udskiltes fra den sognekommune, den hidtil havde været en del af, og opnåede en delvis købstadskommunal status, som blev fuldstændig fra 1907 og førte til en udbygning af forvaltning og institutioner svarende til landets mindre købstæder. Med etableringen af Det danske Stålvalseværk i 1942 til produktion af profil- og stangjern på basis af affald accelereredes Frederiksværk urbanisering med bebyggelser i yderdistrikter uden for det ældre brokvarter så meget, at byens folketal i midten af det 20. århundrede var blevet næsten tredoblet siden århundredskiftet.

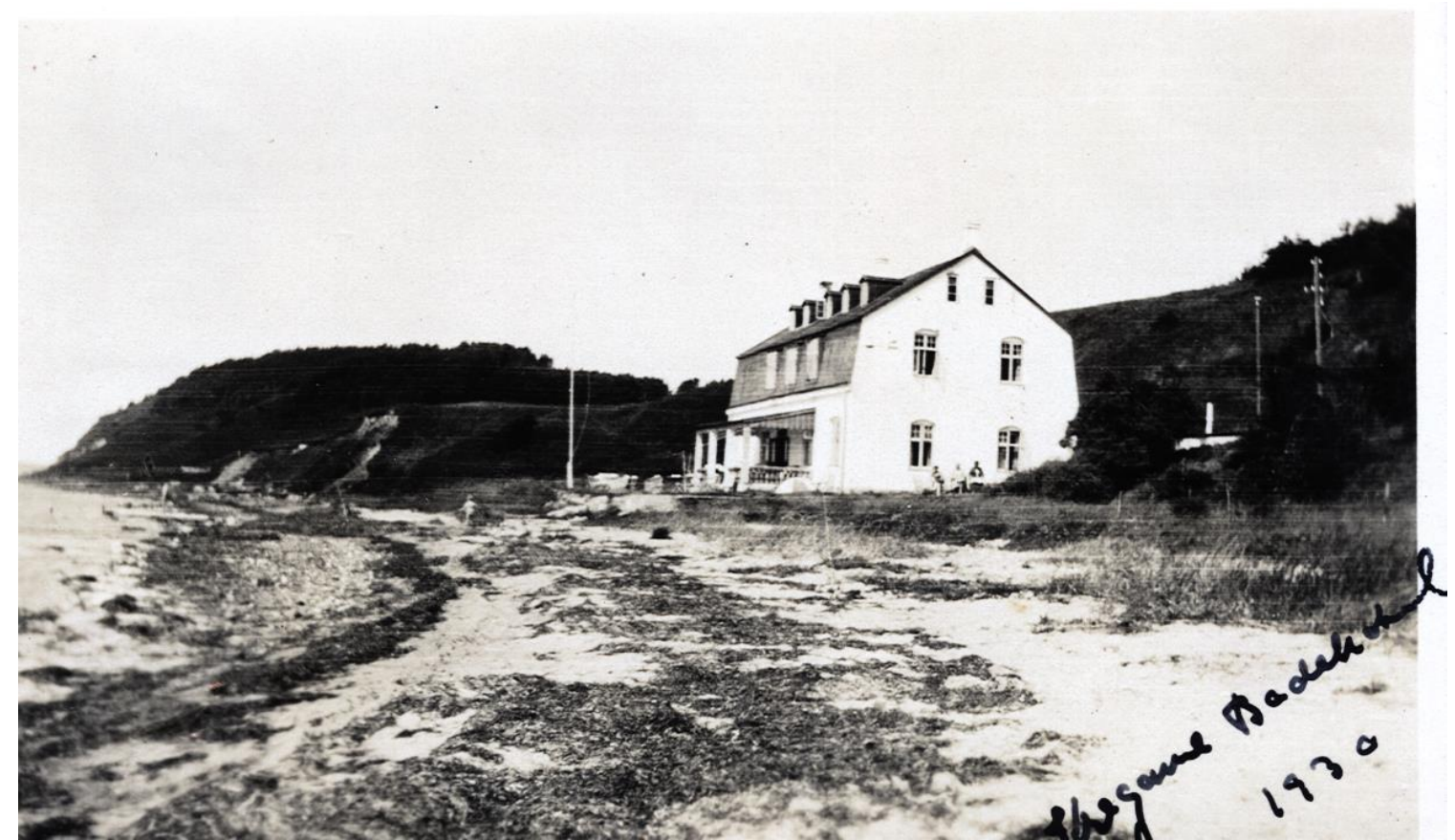

Ved Roskilde Fjords nordside og nordligste østside var der op til midten af det 20. århundrede opstået en vis landliggerkultur for det bedre hovedstadsborgerskab. Bl.a. repræsenteret ved Kregme Badehotel; her fotograferet $i$ 1930. Omfanget af denne særlige feriekultur, kunne dog ikke sammenlignes med den samidige ved Kattegatkysten, men var sammen med udsigterne over og det kuperede landskab ved Roskilde Fjords øst- og nordside med til at give området en karakter af en attraktion for sommerbosætning (Industrimuseet Frederiks Værk, Arkivet)

Syd for Frederiksværk og ned til Frederikssund indgik Roskilde Fjords kystbælte i et landdistrikt omfattende fire landsogne fordelt på tre sognekommuner. Med Frederiksværks urbanisering, forløbet af Hillerød-Frederiksværk Banen og landevejene fra Frederiksværk til henholdsvis Hillerød og Frederikssund, der benyttedes af flere privat- eller privatbaneejede rutebillinjer, fik de to syd for byen liggende sognekommuner gennem den første halvdel af det 20. århundrede en noget større bebyggelse.

Frederiksværks sydlige yderdistrikt havde således frem til midten af århundredet bredt sig langs banelinjen og ind i den nordlige del af Kregme Sogn, og de to kirkesognelandsbyer, 
Kregme og Ølsted, havde i samme periode udviklet sig til mindre rurale stationsbyer med $\mathrm{i}$ 1950 hver 488 og 346 indbyggere og med 56 procent af den beskæftigede befolkning i byerhverv. Begge stationsbyer havde fået kro og centralskole, i Ølsted var der etableret telefoncentral, hotel, bank, sparekasse, andelsmejeri og en gasbeton- og kalksandstensfabrik og på holdepladsen Grimstrup, på banetrækningen Ølsted-Skævinge, kartoffelmelsfabrik, mørtelværk og grusgrav. Industrielle anlæg, der både havde det lokale opland og hovedstadsmetropolen som afsætningsmarked.

I modsætning til kystbæltets to nordlige landsogne havde de to sydlige, Sigerslevvester og Græse, ned mod Frederikssund fortsat alene karakter af landdistrikter med kirkesognelandsbyer, underordnede landsbyer og mindre husklynger. Sognene blev gennemskåret af landevejen Frederiksværk-Frederikssund og frem mod midten af det 20. århundrede betjent af privatbanens rutebilslinjer: Frederikssund-Skævinge-Hillerød og Frederiksværk-Hillerød.

Frem til samme tidspunkt var de fire sognes kyststrækning langs Roskilde Fjord et udpræget landdistrikt. Kendetegnet af spredte bebyggelser med mindre husklynger og enkeltestående gårde. I den nordlige og mere kuperede del dog med en noget større bebyggelse end i den sydlige del, der i det væsentligste henlå som engarealer. ${ }^{31}$

\section{Kystbæltet: Frederikssund-Roskilde}

Med udgangspunkt i en lang periode som færgested med forbindelse til Hornsherred blev Frederikssund fra slutningen af 1500-tallet en ladeplads for købstaden Slangerup længere ind i landet, der særlig i det 18. århundrede voksede så meget, at den ved indgangen til det nye århundrede havde 262 indbyggere og ved ned nedlæggelsen af Slangerup som købstad overtog denne status. I kraft af et betydeligt opland og etableringen af en bro over Roskilde Fjord i 1867 og en jernbanen København-Frederikssund, Frederiksundbanen, øgedes byens handel, ligesom dens industrialisering og urbanisering indledtes og frem til århundredskiftet kom til at omfatte et dampspinderi, flere jernstøberier og maskinfabrikker og et svineslagteri. Med en befolkning på 2.300 indbyggere havde byen næsten firedoblet sin befolkning siden midten af århundredet. En erhvervsøkonomisk udvikling og urbanisering, der forsatte op gennem det 20. århundredes første halvdel, og som ved midten af dette havde ført til, at Frederikssunds yderdistrikter var vokset ind i den tilstødende sognekommune og bragt byens folketal op på 4.143; en tilvækst på knapt 80 procent siden århundredskiftet.

I kysbæltet syd for Frederikssund og ned mod Roskilde bevarede landskabet op gennem det første halvdel af det 20. århundrede sin rurale karakter, og bestod med landbrug som det helt dominerende erhverv af syv sogne, fordelt på fem sognekommuner, omfattende kirkesognelandsbyer, tilliggende landbyer og husklynger. Gennem den nordlige del af bæltet løb i dets østlige del landevejen Frederikssund- Ølstykke- København, mens dens sydelige del blev gennemskåret af landevejen Hillerød-Roskilde. Landeveje, der på disse strækninger benyttedes af først private rutebilsruter og senere af DSBs rutebiler.

Netop landevejen Hillerød-Roskilde og de efterhånden bedre rutebilsforbindelser bevirkede dog, at kirkesognelandsbyen Jyllinge fik en anden udvikling end andre landsbyer i kystbæltet mellem Frederikssund og Roskilde. Allerede i tiden omkring første verdenskrig havde Jyllinge 200 indbyggere, og omfattede ud over kirke og præstegård, en skole fra 1910, en ældre købmandsforretning, et andelsmejeri fra 1890, en brugs for samme år samt en havn, anlagt 1907, til det betydelige fiskeri, der udgik fra landsbyen og var samtidig hjemsted for JyllingeGundsømagle Sognekommune. Med fiskermiljøet havde Jyllinge, som ved Skagen og Kattegatkysten, i sommerperioden desuden tiltrukket en del af hovedstadens kunstnere, og med dem fulgte andre landligger, der indlogerede sig hos de lokale eller på badehotellet Søfryd fra 1916. 
Op gennem det 20. århundrede undergik Jyllinge en, i forhold til andre landdistrikter, vis urbanisering, og udviklede sig som en art landevejsby i det rurale og byfattige område mellem Ølstykke og Roskilde. I perioden fik landevejsbyen folkebogsamling, telefoncentral, sparekassefilial, en pakkassefabrik, et bådebyggeri, en feriekoloni og i 1953 et stort alderdomshjem, der tillige husede kommunekontor og sognekommunens folkebibliotek. Med denne udvikling betegnedes Jyllinge i midten af århundredet som en bymæssig bebyggelse, og havde opnået 500 indbyggere, svarende til 70 procent af sognets folketal, hvoraf 40 procent var beskæftiget ved landbrug og fiskeri og de resterende knapt 60 procent i byerhverv fordelt med 36 procent i industri og håndværk, 16 procent i handel og transport og 7 procent ved administration og i liberale erhverv. ${ }^{32}$

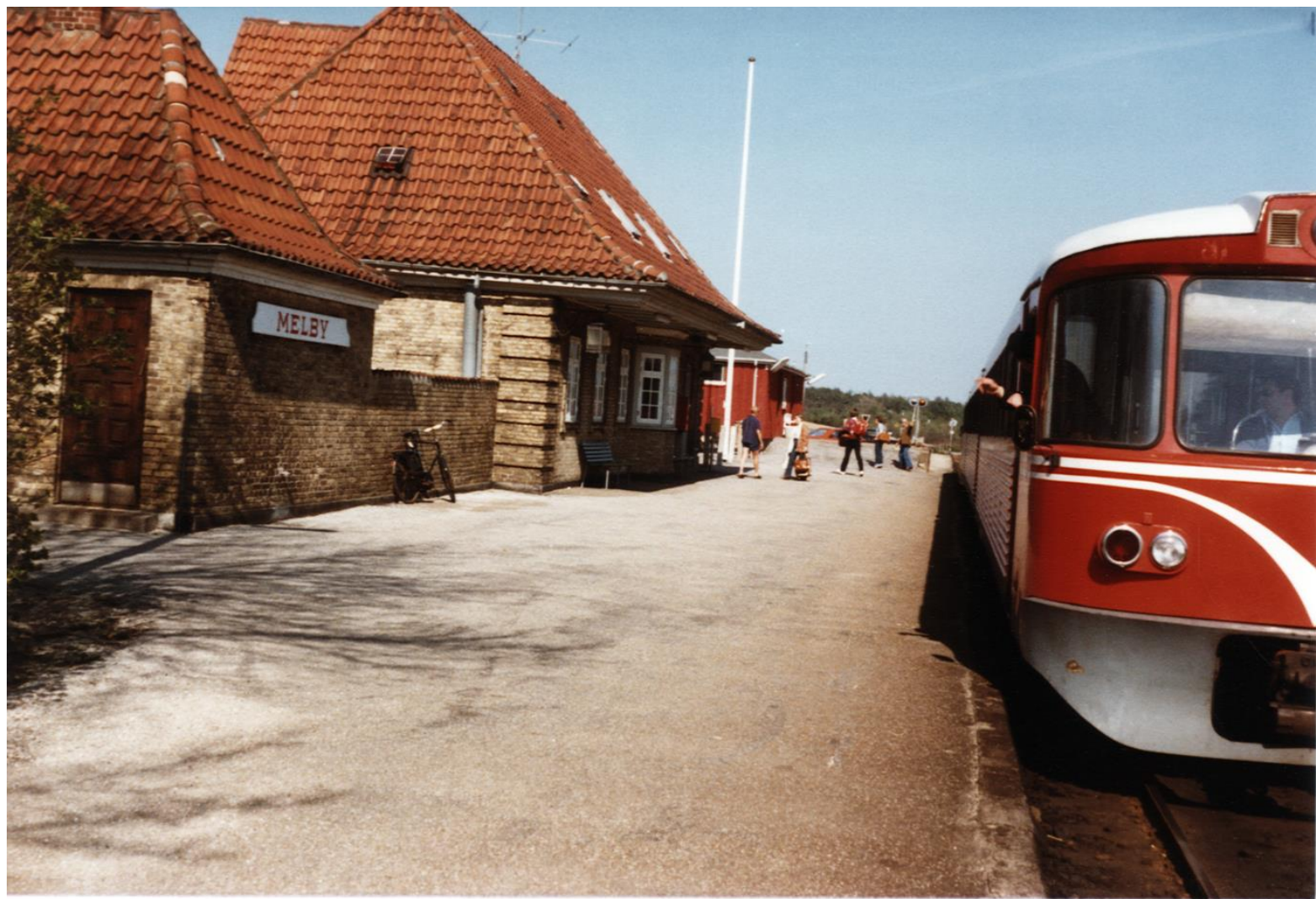

Ogsa til sommerhusbyerne ved Roskilde Fjords nord-og østside forbedredes de vej- og kollektivtrafikale forbindelser $i$ efterkrigstiden. Bl.a. ved indsættelse af skinnebusser og senere Y-tog som dette ved Melby Station i 1981. (Industrimuseet Frederiks Værk, Arkivet)

\section{Kystbæltets sommerhusbyer}

Med de åbne kyststrækninger, stærkt forbedrede kollektive trafikforbindelser, tæt liggende landeveje til hovedstadsmetropolens centrale dele og købstædernes, stationsbyernes og de større landsbyers byerhverv havde kystbæltet ved Roskilde Fjords nordlige og østlige del særlig gode forudsætninger for lokaliseringen af en betydelige del metropolens sommerhusbyer. Ved kystbæltet opstod således i allerede i den første efterkrigstid syv sommerhusbyer, der ved udgangen af efterkrigstidsperioden rummede i alt 4.876 sommerhuse (tabel III.18). Med 12,1 procent af hovedstadsmetropolens samlede mængde opførte sommerhuse i hele efterkrigstidsperioden, fordelt med 12,7 procent i den første efterkrigstid og 9,1 i den sidste del af perioden, blev kystbæltet ved Roskilde Fjords nord-og østside det område i metropolens åbne land, hvor koncentrationen af sommerhusbyer blev tredjestørst.

Med de særlige attraktioner, der knyttede sig til egnene op til Kattegatkysten og Arresøs baglande, karakteren af udsigterne fra og kysternes beskaffenhed ved Roskilde Fjord nordlige del og de hertil særligt gode vej- og kollektivtrafikale forbindelser påbegyndtes 
sommerhusudstykningerne- og bebyggelserne allerede i de første år af 50 'erne på Halsnæs sydside og i kystbæltet mellem Frederiksærk og Frederiksund. Tidligst i sommerhusbyerne på det sydlige Halsnæs og ved Lille Kregme, Kregme og Ølsted strande og umiddelbart efter i sommerhusbyen ved Store Havelse. Og i sådant omfang at knapt 54 procent af den første efterkrigstids sommerhusbyggeri ved Roskilde Fjord nord- og østside blev lokaliseret til disse sommerhusbyer, der fra Lille Kregme i nord til St. Havelse i syd kom til at udgøre et næsten sammenbygget sommerhusbybælte, som det kendtes fra Kattegatkysten. (tabel III.19). Et sommerhusbybælte, som, i lighed med Kattegatkystens, sammen baglandets pendlersatellitbyer i højere grad integreredes i hovedstadsmetropolens ydre bydannelser.

Tabel III.18. Procentvis fordeling af sommerhuse samt udstyknings- og bebyggelsesperioder i sommerhusbyer ved Roskilde Fjords nord- og østside, 1950-1990.

\begin{tabular}{|l|l|l|l|l|l|}
\hline \multirow{2}{*}{ Sommerhusby } & Procentandel af antal sommerhuse & Udstykningsperiode & \multirow{2}{*}{ Bebyggelsesperiode } \\
\cline { 2 - 4 } & $1950-1973$ & $1974-1990$ & $1950-1990$ & & \\
\hline Store Karlsminde & 7,1 & 5,4 & 6,8 & $1950-1980$ & $1951-1988$ \\
\hline Hanehoved & 1,2 & 0,0 & 1,1 & $1950-1965$ & $1950-1972$ \\
\hline Lille Kregme Strand & 12,1 & 8,1 & 11,5 & $1950-1978$ & $1950-1990$ \\
\hline Kregme Strand & 9,4 & 12,2 & 9,8 & $1952-1978$ & $1951-1990$ \\
\hline$\varnothing$ Østed Strand & 8,2 & 6,2 & 7,9 & $1951-1967$ & $1952-1990$ \\
\hline St. Havelse Strand & 15,7 & 21,9 & 16,6 & $1952-1973$ & $1955-1990$ \\
\hline Jyllinge & 46,3 & 46,2 & 46,3 & $1955-1970$ & $1956-1985$ \\
\hline Total & 100 & 100 & 100 & $1950-1980$ & $1950-1990$ \\
\hline
\end{tabular}

Kilde: Henvisninger under Appendix VI.B.

Som følge af udfyldningen af sommerhusbyerne såvel ved Kattegatkysten som i kystbæltet mellem Frederiksværk og Frederikssund og tidlige særlige rekreative hensyn til kyststrækningen syd for Frederikssund, se kapitel 10, blev den sidste og i øvrigt også største sommerhusby i kystbæltet ved Roskilde Fjords nord- og østside lokaliseret til Jyllinge i kystbæltet mellem Frederikssind og Roskilde. Med den landliggerbosætning, der tidligt havde kendetegnet landvejsbyen Jyllinge, den relativt korte afstand fra hovedstadsmetropolens indre dele og direkte rutebilsforbindelser fra Roskilde, Tåstrup og Ballerup var der her skabt forudsætninger for, at der i midten af 40 'erne gennemførtes to mindre udstykning og en efterfølgende sommerhusbebyggelse nord for Jyllinge, ved Jyllinge Nordmark, og umiddelbart syd for landsbyen; også betegnet: Jyllinge Syd.

Tabel III.19. Procentvis fordeling af sommerhuse i sommerhusbyer ved Roskilde Fjords østsside, 1950-1990.

\begin{tabular}{|l|l|l|l|}
\hline & $1950-1973$ & $1974-1990$ & $1950-1990$ \\
\hline Halsnæs & 8,3 & 5,4 & 7,9 \\
\hline Kystbæltet Frederiksværk-Frederikssund & 45,4 & 48,4 & 45,8 \\
\hline Kystbæltet Frederikssund-Roskilde & 46,3 & 46,2 & 46,3 \\
\hline Total & 100 & 100 & 100 \\
\hline
\end{tabular}

Kilde: Henvisninger under Appendix VI.B.

Udstykninger, der fra midten af 50'erne og frem til omkring 1970 efterfulgtes af masseudstykninger ved Jyllinge Nordmark og fra starten af 60' erne og de følgende 10 år af tilsvarende meget store udstykninger i Jyllinge Syd. Fra midten af 60 'erne vandt byggeriet af enfamiliehus stadig større indpas ved Jyllinge Nordmark, og blev nærmest enerådende ved bebyggelsen af de store udmatrikulerede områder i Jyllinge Syd. Jyllinge påbegyndte derved omdannelse fra sommerhusby til en af hovedstadsmetropolens satellitbyer uden for metropolens købstadsring.

En proces, der forstærkes op gennem den sidste efterkrigstid, hvor der øst for landsbyen og mellem Jyllinge Nordmark og de store kvarterer med enfamiliehuse syd for landsbyen opstod et egentlig bycentrum med lavt almennyttigt boligbyggeri, et forretningscenter, to store folkeskoler, et plejecenter, bibliotek, sportshal og et lavt almennyttigt boligbyggeri. I takt med bebyggelsen af området Tangbjerg og industrikvarteret Værebro begyndte Jyllinge efterhånden at vokse sammen med forstæderne Ølstykke og Stenløse på det radiale forstadsbånd langs 
Frederikssundbanen, og fik dermed i højere grad karakter af en af hovedstadsmetropolens forstæder. ${ }^{33}$

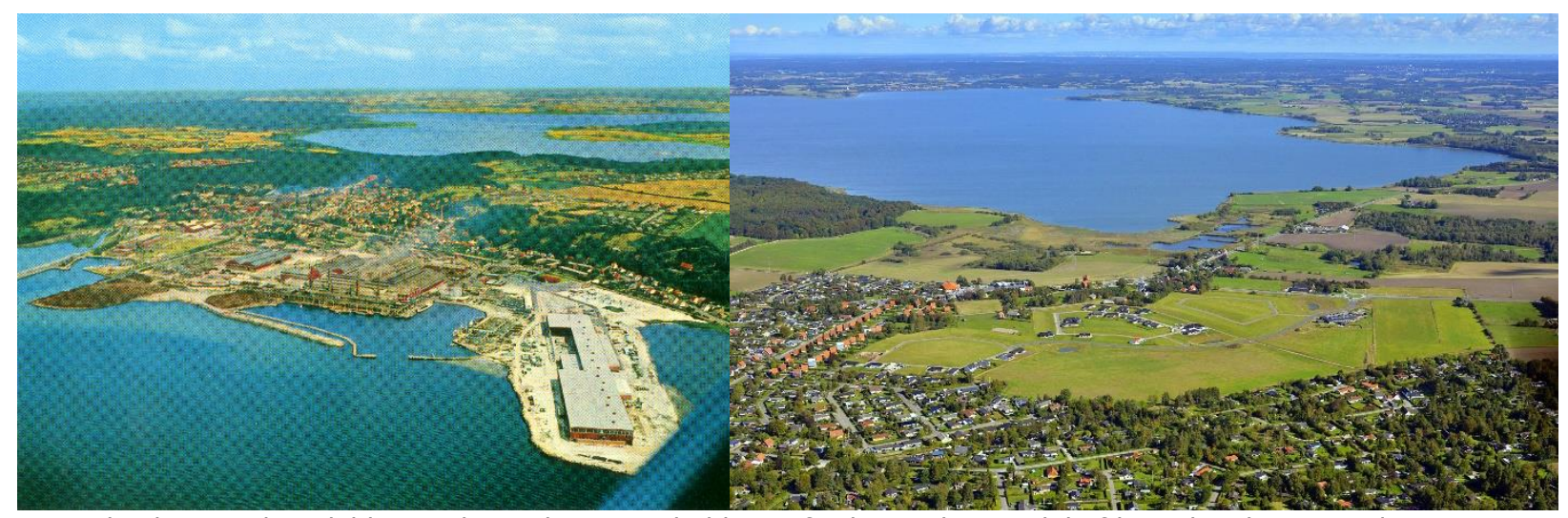

Sommerhusbyer ved Roskilde Fjords nord og østside blev $i$ efterkrigstiden en del af hovedstadsmetropolens randområder som følge af deres nære beliggenhed i forhold til større byer. F.eks. købstaden Frederiksværk; billedet til venstre i 1965, og stationsbyen Kregme, der i perioden udviklede sig til en af Nordsjællands mange pendlersatellitbyer; billedet til højre i 2010 (Industrimuseet Frederiks Værk, Arkivet)

\section{Bystruktur}

Selv om sommerhusbyerne mellem Kregme Strand og St. Havelse fik en mere sammenhængende form, fik sommerhusbydannelser ved Roskilde Fjord nordlige og østlige del, i modsætning til sommerhusbybæltet ved Kattegatkysten, i kraft af regionale fredningsdispositioner i højere grad karakter af afgrænsede og fra hinanden adskilte sommerhusbyer; jf. Kapitel 9. Kun sommerhusbyerne Store Karlsminde og Lille Kregme voksede sammen med henholdsvis Hundested stationsby og det bælte af enfamiliehuse, der på samme tid lagde sig uden om Lille Kregme landsby, mens det som helhed lykkedes gennem lokalkommunale byplanmæssige dispositioner at afgrænse udbredelsen af kystbæltets sommerhusbyer til områderne mellem kyststrækningerne og de jernbane- og landevejslinjeføringer, der løb mellem 1 og 3 km længere inde i landet; jf. APPENDIX VII.

\section{Bebyggelse}

Kystbæltet kom såedes op gennem efterkrigstiden til at omfatte, på bar mark opståede, syv sommerhusbyer, hvor alene sommerhusbyen Jyllinge med knapt 2.300 sommerhushuse kom til at indgå i gruppen af hovedstadsmetropolens store sommerhusbyer (tabel III.20). Med henholdsvis 808 og 563 sommer placerede sommerhusbyerne St. Havelse og Lille Kregme Strand sig i kategorien af større sommerhusbyer, mens sommerhusbyerne Store Karlsminde, Kregme Strand og Ølsted strand indgik i gruppe af mellemstore sommerhusbyer. Med 52 sommerhuse kom sommerhusbyen Hanehoved til at indgå som en af de mindste $\mathrm{i}$ hovedstadsmetropolens sommerhusbykoncentrationer ved Kattegatkysten og i kystbæltet ved Roskilde Fjords nord- og østside og Hornsherred.

Tabel III.20. Procentvis fordeling efter sommerhusby- størrelse ved Roskilde Fjords østside, 1950-1990

\begin{tabular}{|l|l|l|}
\hline & $\begin{array}{l}\text { Procentvis fordeling efter antal } \\
\text { huse }\end{array}$ & Antal sommerhusbyer \\
\hline Store somerhusbyer (over 1.000 huse) & 46,2 & 1 \\
\hline Større sommerhusbyer (500-999 huse) & 28,1 & 2 \\
\hline Mellemstore sommerhusbyer (200-499) & 24,6 & 3 \\
\hline Mindre sommerhusbyer (Mindre end 199) & 1,1 & 1 \\
\hline Total & 100 & 7 \\
\hline
\end{tabular}

Kilde: Henvisninger under Appendix VI.B.

Da spredte og små sommerhusbebyggelser i 30 'erne og særlig i 40 'erne var kommet til at udgøre et alternativ til sommerhusbybælterne ved Kattegatkysten og Køge Bugt og periodens tre større sommerhusenklaver, var der ved samtlige af sommerhusbyerne i kystbæltet ved Roskilde Fjords nord- og sydside i perioden opstået et sådant sommerhusbyggeri. Hertil kom, 
at der ved samtlige af sommerhusbyerne før midten af det 20. århundrede var opstået forskellige former for feriekolonier, ved Ølsted Strand og Jyllinge mindre badehoteller og i Store Karlsminde et statsligt ungdomshjem for drenge. Bebyggelser, der dannede udgangspunkt for, at kystbæltes sommerhusbyer i efterkrigstiden fik række fælles træk.

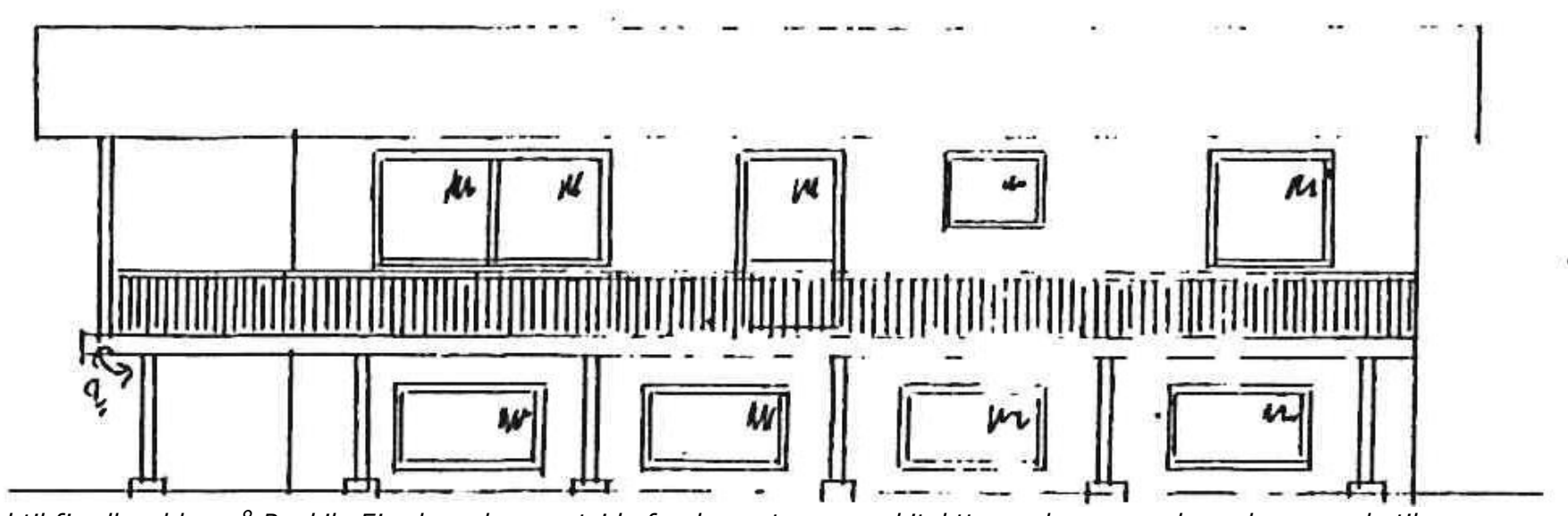

Ud til fjordbredden på Roskile Fjord nord- og østside forekom store og arkitekttegnede sommerhus, der svarede til mange af Kattegatkystens. Her et eksempel fra sommerhusbyen Store Karlsminde i 1972 (Halsnæs Kommune digitale byggesager, https://www.weblager.dk/)

Sommerhusbyerne dannedes således alle som langstrakte bebyggelser langs kystlinjen og mellem denne og de jernbanelinjer og landeveje, der i en afstand på en halv til tre km løb inde i landet. Langs større eller mindre systemer af side-, tvær- og parallelveje til landevejene førende oprindelige primær- eller sekundærbiveje bebyggedes de enkelte sommerhusbyer som tidsmæssigt forskudte koncentriske lag fra kystlinjen og frem til de afgrænsende jernbaneeller vejlinjer. Udover mindre og ofte spredte fællesarealer blev kystbæltes sommerhusbyer fuldt bebygget, dog således at en række offentlige rekreative fredninger og arealerhvervelse, der gennemførtes af hensyn til den brede befolknings kystadgang og- ophold, $\mathrm{i}$ sommerhusbyerne Store Karlsminde, Hannehoved, Lille Kregme Strand og Kregme Strand sikrede større fælles områder, der tillige forhindrede, at sommerhusbyerne i den nordlige del af kystbæltet mellem Frederiksværk og Frederikssund smeltede helt sammen som et sommerhusbybælte, jf. Kapitel 9. ${ }^{34}$

\section{Social sammensætning}

Selv om gruppen selvstændige og funktionærer var stærkt overrepræsenteret og arbejdere tilsvarende underrepræsenterede som førstegangssommerhusejere i sommerhusbyerne ved Roskilde Fjords nord- og østside i forhold til den sociale sammensætning af erhvervsbeskæftige i hovedstadsmetropolens første efterkrigstid, blev den sociale sammensætning af disse her noget mere jævn end i sommerhusbybæltet ved Kattegatkysten (tabe III.21). Arbejderklassen andel af denne ejergruppe lå så således væsentlige højere end ved den nordsjællandske kyst og noget over samme klasses andel af førstegangssommerhusejere i hovedstadsmetropolen som helhed. Med en mindre andel af funktionærer og selvstændige svarede sammensætningen af denne ejergruppe ved Roskilde Fjord nord- og østside til gengæld i det væsentligste til gennemsnittet for metropolens sommerhusbyer i gennemsnit.

Den noget jævnere sociale fordeling af førstegagssommerhusejere i sommerhusbyerne ved Roskilde Fjords nordlige og østlige del i forhold til sommerhusbybæltet ved Kattegatkysten omfattede tillige fordeling af disse på bopælsområder i hovedstadsmetropolen og på boligbebyggelsesform (tabel III.22). På dette område svarede fordelingen af sommerhusejere på fjordkystens strækninger i højere grad til metropolbefolkningens fordeling og gennemsnitstallene for ejergruppen i samtlige af hovedstadsmetropolens sommerhusbyer. 

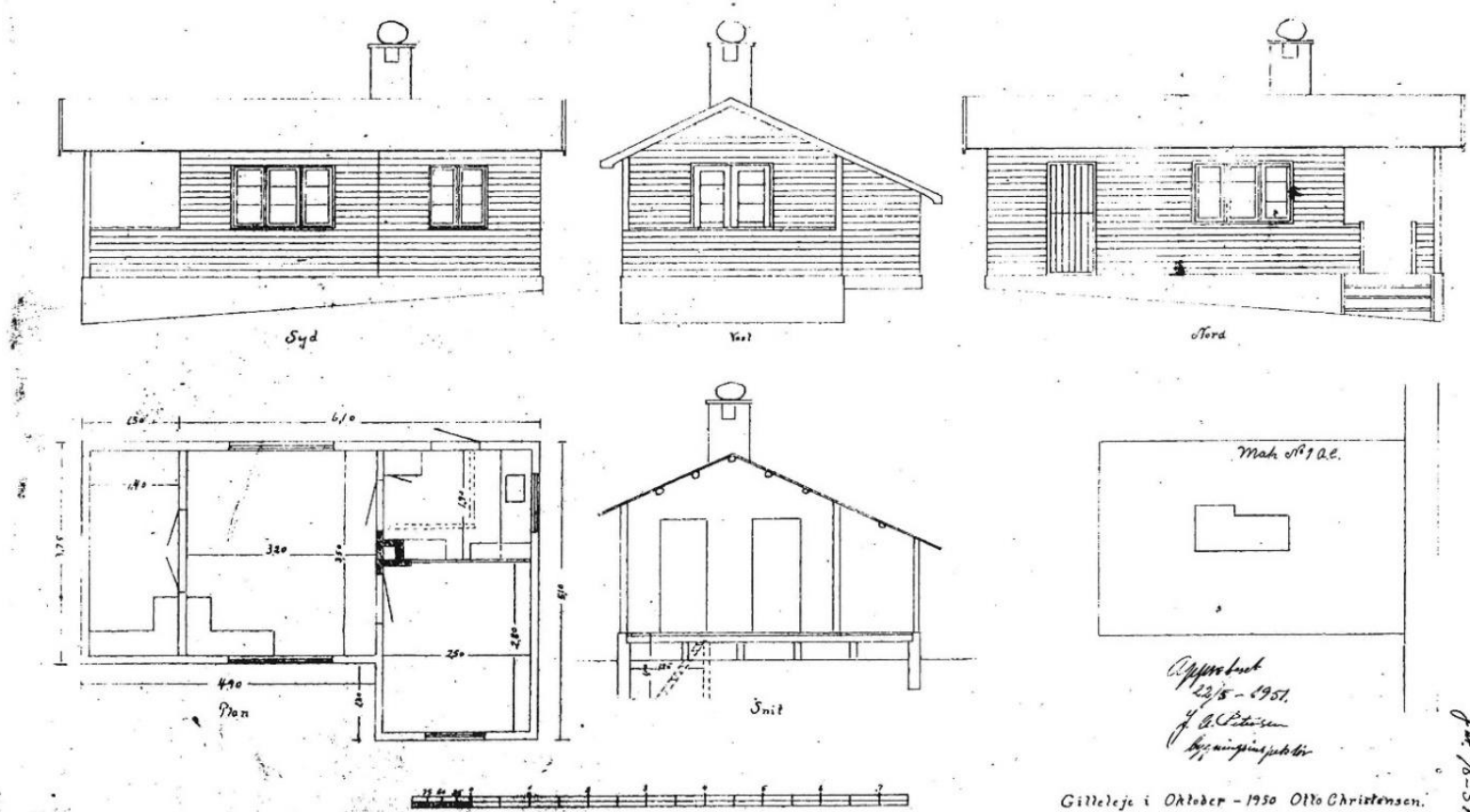

Sord

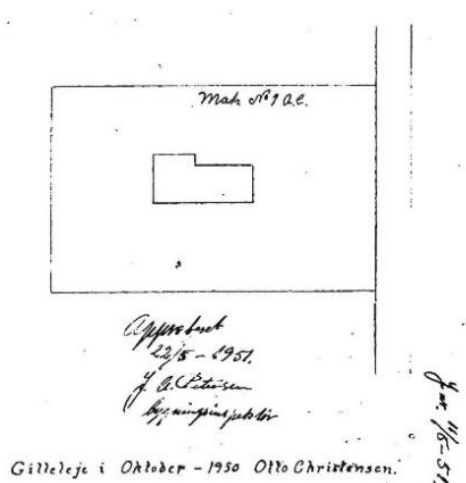

Da sommerhusbyerne ved Roskilde Fjord nord-og østside dannedes tidligt i den første efterkrigstid, kom disse som $i$ sommerhusbybælte ved Kattegatkysten til at omfatte et betydeligt volumen af den ældre type sommerhuse, der opførte i den første halvdel af 50'erne. Dette i sommehusbyen Lille Kregme Strand fra 1951 er et karakteristisk eksempel. Opført på et støbt fundament af en lokal tømmermester og pa knapt $30 \mathrm{~m}^{2}$ omfattende stue med skorsten, et værelse og køkken med indlagt vand og afledning til sivebrønd (Halsnæs Kommune digitale byggesager, https://www.weblager.dk/)

For så vidt den social sammensætning af førstegangssommerhusejere i sommerhusbyer ved Roskilde Fjord nord- og østside skilte de to sommerhusbyer på Halsnæs sydside, Store Karlsminde og Hanehoved, sig ud fra de øvrige. Førstegangssommerhusejere fra arbejderklassen udgjorde således her alene knapt 6 procent, og selv om det øvrige funktionærlag og mindre selvstændige tegnede sig for godt 60 procent af samme, kom højindkomstslaget af højere funktionærer og større selvstændige til at indgå med næsten en tredjedel. En social sammensætning af førstegangsommerhusejere, der svarede til samme i Kattegatkysten sommerhusbybælte og tillige satte sig igennem i forhold til disse bopæl. Ikke mindre end 42 procent førstegangssommerhusejerne på Halsnæs sydside havde bopæl i velhaverforstæderne på Nordegnen og beboede for 55 procents vedkommende et enfamiliehus.

Tabel III.21. Procentvis social sammensætning af førstegangssommerhusejere i sommerhusbyerne ved Roskilde Fjords østside, 1950-1973, og i hovedstadsmetropolen, 1950 og 1970.

\begin{tabular}{|c|c|c|c|c|c|c|}
\hline \multirow[t]{3}{*}{ Stilling } & \multirow{3}{*}{\multicolumn{2}{|c|}{$\begin{array}{l}\text { Sommerhusejere, } \\
1950-1973\end{array}$}} & \multicolumn{4}{|c|}{$\begin{array}{l}\text { Hovedstadsmetropolens erhvervsbeskæftigede } \\
\text { befolkning }\end{array}$} \\
\hline & & & \multicolumn{2}{|c|}{1950} & \multicolumn{2}{|c|}{1970} \\
\hline & & & Hovedstaden & Forstæder & Hovedstaden & Forstæder \\
\hline Større selvstændige & 5,1 & & & & & \\
\hline Mindre selvstændige & 14,1 & & & & & \\
\hline Selvstændige, total & & 19,2 & 11,7 & 17,4 & 7,1 & 9,5 \\
\hline Ledende funktionærer & 7,1 & & & & & \\
\hline Akademisk uddannede funktionærer & 9,1 & & & & & \\
\hline Højere funktionærer, i alt & 16,2 & & & & & \\
\hline Øvrige funktionærer & 41,5 & & & & & \\
\hline Funktionærer, total & & 57,7 & 33,0 & 24,2 & 42,6 & 44,6 \\
\hline Faglærte arbejdere & 19,4 & & & & & \\
\hline Ufaglærte arbejdere & 3,7 & & & & & \\
\hline Arbejdere, total & & 23,1 & 53,3 & 58,4 & 50,0 & 44,1 \\
\hline Total & 100 & 100 & 100 & 100 & 100 & 100 \\
\hline
\end{tabular}

Kilde: Henvisninger under Appendix VI.B. Bro: Hovedstadsmetropolen- den danske byregion 2020, s. 547-548. 
Tabel III.22. Procentvis fordeling af bopælsområde og boligform for førstegangssommerhusejere i sommerhusbyerne ved Roskilde Fjord østside, 1950-1973, og i hovedstadsmetropolen, 1950 og 1970.

\begin{tabular}{|l|l|l|l|}
\hline & Sommerhusejere & Hele hovedstadsmetropolens befolkning \\
\hline Bopæl i: & $1950-1973$ & 1950 & 1970 \\
\hline Hovedstaden & 51,2 & 61,9 & 41,8 \\
\hline Nordegnen & 24,9 & 12,2 & 13,5 \\
\hline Nordvestegnen & 13,7 & 3,8 & 8,5 \\
\hline Vestegnen & 7,3 & 7,0 & 15,4 \\
\hline Andet & 3,5 & 15,1 & 20,8 \\
\hline Total & 100 & 100 & 100 \\
\hline Etagebolig & 63,9 & 82,3 & 74,7 \\
\hline Enfamiliehuse & 36,1 & 17,7 & 25,3 \\
\hline Total & 100 & 100 & 100 \\
\hline
\end{tabular}

Anm: Fordelingen på etageboliger og enfamiliehuse omfatter alene hovedstaden og forstadsegnene

Kilde: Henvisninger under Appendix VI.B. Statistiske Årbog for København, Frederiksberg m.m., 1952, s. 1, 55, 191-

192 og 198. https://www.kk.dk/sites/default/files/migrated/sc/1972-aarbog.pdf

https://www.kk.dk/sites/default/files/migrated/sc/1975-aarbog.pdf

Lige på nær de mest kystnære områder, hvor samme højindkomstlaget dominerede, blev den sociale sammensætning af førstegangssommerhusejere i sommerhusbyerne i kystbæltet langs Roskilde Fjord østside derimod mere homogen. Andelen af førstegangssommerhusejer fra arbejderklassen, det øvrige funktionærlag og gruppen af mindre selvstændige varierede således mellem henholdsvis 20-29, 33-41 og 13-21 procent, mens højindkomstlaget af højere funktionærer og større selvstændige alene indgik med 13-24 procent. En social sammensætning, der tillige afspejledes i førstegangssommerhusejernes bopælsforhold. 63-73 procent beboede således lejligheder i etagebyggeri, og mens 50-55 procent havde bopæl i hovedstaden, var de øvrige mere jævnt fordelt over hovedstadsmetropolens øvrige forstadsegne, hvor indkomstniveauet var væsentlig lavere end i nordforstæderne.

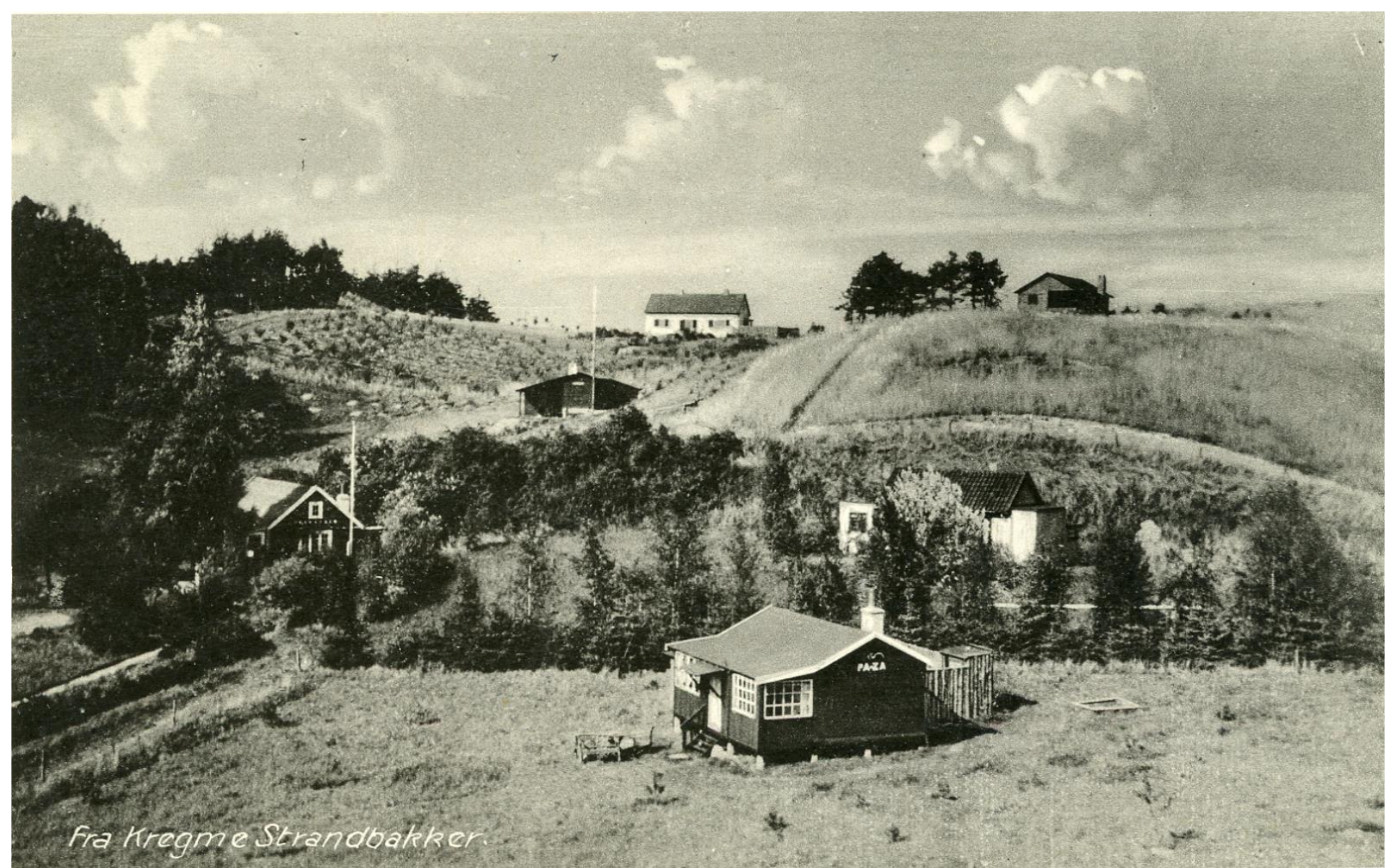

Små og spredtliggende sommerhuse var karakteristisk for den karakter sommerhusbyerne ved Roskilde Fjords nordog østside havde i starten af 50'erne. Her Lille Kregme Strand (Industrimuseet Frederiks Værk, Arkivet) 

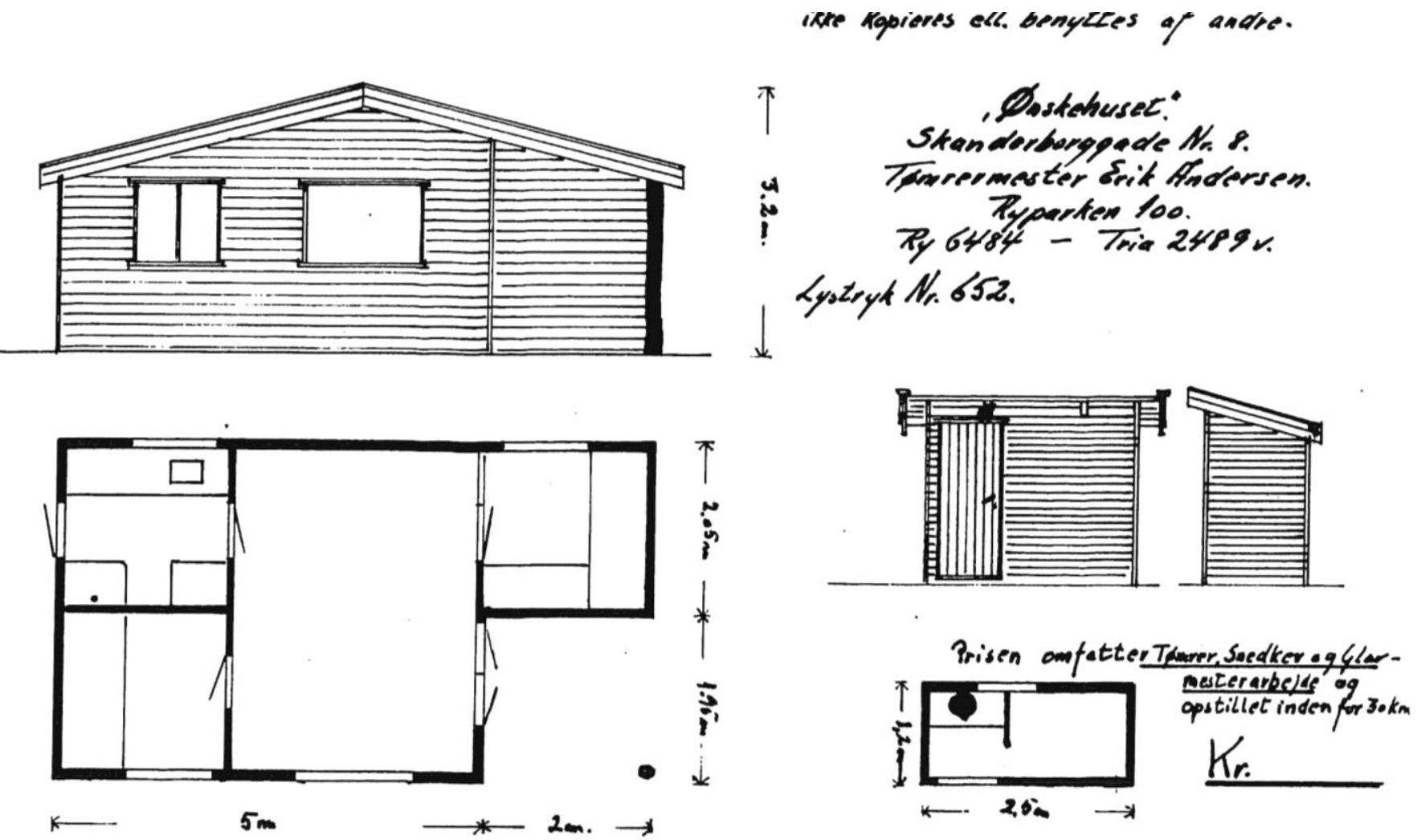

Med den jævnere sociale sammensætning forekom typesommerhuse $i$ videre omfang $i$ sommerhusbyerne ved Roskilde Fjord nord- og østside end i sommerhusbybæltet ved Kattegatkysten. Her en de de tidlige former for typesommerhuse. Et lille hus p̊ 24 m2 fra 1953 med tilhørende skur til redskaber og das. Firmaet bag "Ønskehuset", som det betegnedes, stod en tømmermester fra det københavnske Østerbro, der dog kom til at stå et fătal typesommerhuse.

Alene den i forhold til hovedstadsmetropolens centrale dele mest yderligt beliggende sommerhusbyen, St. Havelse Strand, adskilte sig mere fra kystbæltets øvrige sommerhusbyer. Arbejderklassen tegnede sig her for mere end en fjerdel af førstegangssommerhusejerne og sammen med de godt 60 procent af ejere fra de øvrige funktionærlag og gruppen mindre selvstændige, kom højindkomstlaget af højere funktionærer og større selvstændige til kun at udgøre 13 procent. 53 procent og næsten en tredjedel havde bopæl i henholdsvis hovedstaden og forstæderne på Nordvest- og Vestegnen, og ikke mindre end næsten trefjerdele beboede en lejlighed i etagebyggeri i disse dele af hovedstadsmetropolen. En sammensætning, der i nogen grad også kendetegnede sommerhusbyen Jyllinge, hvor førstegangssommerhusejere fra arbejderklassen udgjorde knapt en fjerdel og sammen med det øvrige funktionærlag og mindre selvstændige, bragte andelen af førstegangsommerhusejere fra højindkomstlaget af højere funktionærer ned på en femtedel. ${ }^{35}$

\section{Sommerhusstandard}

Skilte sommerhusbyerne ved Roskilde Fjords nord- og østside sig for så vidt den sociale sammensætning af førstegangssommerhusejere ud fra sommerhusbæltet ved Kattegatkysten, gjaldt det tillige karakteren af sommerhusbebyggelsen. Fjordstrækningens sommerhuse havde således en kvalitet og størrelse, der i værnlig grad svarede til hovedstadsmetropolens gennemsnitlige paramenterne for sommerhusstandarden (tabel 23 og 24). Dog således at husene i sommerhusbyerne ved Roskilde Fjords nord- og østside i videre omfang var fuldisolerede og opført på et støbt fundament, og kun i et yderste begrænset omfang ikke var udstyret med indlagt vand og spildevandsafledning. Endelig var det her mindre udbredt at opføre et skur, inden et egentligt sommerhus rejstes på grunden. 

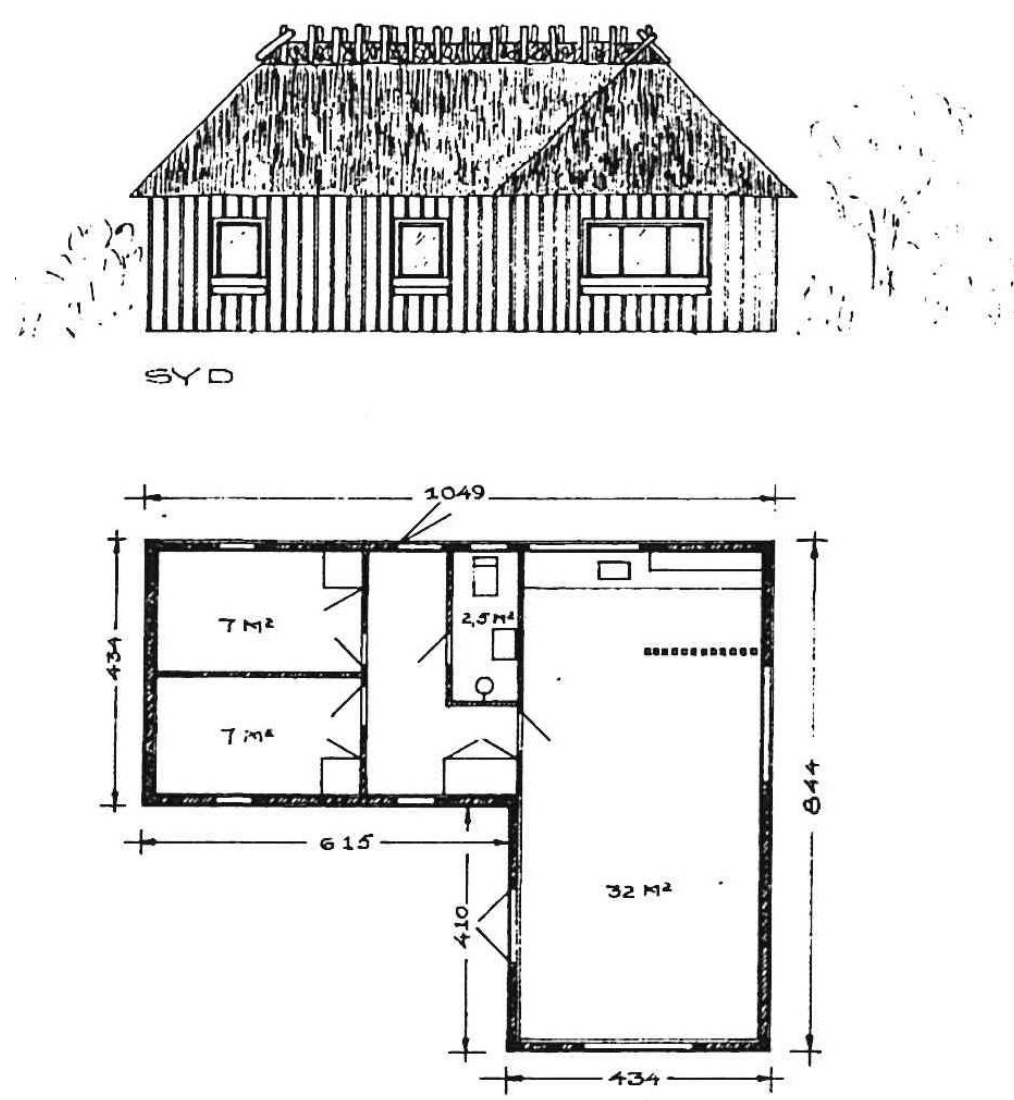

En tilsvarende begrænset produktion af typesommerhuse opnåede firmaet Egeskov Feriehuse, der 11969 stod bag dette strătækte hus i sommerhusbyen Store Havelse (Halsnæs Kommune digitale byggesager, https://www.weblager.dk/)

Som følge af den relativt udtalte homogenitet i sammensætningen af førstegangssommerhusejere og dermed mere ensartede økonomiske forudsætninger for størrelsen og udrustningen af det første sommerhusbyggeri i sommerhusbyerne i kystbæltet ved Roskilde Fjord nord- og østside, blev disse tillige forholdsvis homogene målt i forhold til parametrene for sommerhusstandarden.

Alene i sommerhusbyerne på Halsnæs sydside, hvor højindkomstlaget af førstegangsommerhusejere var mest udbredt, blev arealet af sommerhusene større end gennemsnittet i kystbæltets sommerhusbyer. En større andel af sommerhusene her var desuden opført med arkitektbistand og som dyrere sommerhustyper, fra bl.a. Myresjö-huset og Skarridsø Huset, udstyret med bad, spildevandsafledning og skorsten og fuldisolerede. Modsat sommerbyen ved Jyllinge, hvor indkomstgrundlaget blandt

førstegangssommerhusejerne var lavere og, hvor sommerhusenes areal var mindre end gennemsnittet i sommerhusbyerne ved Roskilde Fjords nord- og østside og østlige del og havde en større andel med to og tre værelser. Husene var her desuden i højere grad opført som selvbyg og billigere typesommerhuse, fra bl.a. Jeppesens Savværk og Ganløse Huset, og i mindre grad udrustet bad, indlagt vand, spildevandsafledning, skorsten og fuldisolerede. Endelig omfattede sommerhusbyen ved Jyllinge flere sommerhuse, der var rejst på piller, ligesom en større andel var blevet opført nogle år efter, at der først var rejst et skur eller garage på grunden.

For så vidt sommerhusene i sommerhusbyerne i kysbæltet mellem Frederiksværk og Frederikssund varierede standarden kun i mindre grad. Dog var sommerhusene i den nordlige del, ved Lille Kregme og Kregme strande, mindre end og ikke udstyret i samme omfang som 
dem i den sydlige del ved Ølsted og St. Havelse strande. Afgørende var, at sommerhusbyerne i den nordlige del bebyggedes og udbyggedes tidligere end dem i den sydlige del, hvorved de større hustyper og standardforbedringer, der kendetegnede det efterfølgende sommerhusbyggeri her kunne sætte sig mere igennem. ${ }^{36}$

Tabel III.23. Parametre for sommerhusstandarden i sommerhusbyerne ved Roskilde Fjords østside, 1950-1973.

\begin{tabular}{|c|c|c|c|c|c|}
\hline \multirow[t]{2}{*}{ Opført, i procent: } & Som selvbyg & Af bygmester & Med arkitektbistand & Af byggefirma & Total \\
\hline & 8,4 & 33,4 & 8,2 & 50,0 & 100 \\
\hline \multicolumn{6}{|c|}{ Rumfordeling, i procent: } \\
\hline 1 rum & 2 rum & 3 rum & 4 rum & 5 el. fl. Rum & Total \\
\hline 0,3 & 22,3 & 51,3 & 20,2 & 5,9 & 100 \\
\hline \multirow[t]{2}{*}{ Toilet, i procent: } & Udenfor huset & I huset & Total & \multirow{2}{*}{\multicolumn{2}{|c|}{$\begin{array}{l}40,8 \text { procent med bad. } \\
1,6 \text { procent uden køkken }\end{array}$}} \\
\hline & 14,8 & 85,2 & 100 & & \\
\hline Areal: & \multicolumn{2}{|c|}{ Mellem 15-129 $\mathrm{m}^{2}$.I gennemsnit 50,1 $\mathrm{m}^{2}$} & Udvidelser: & \multicolumn{2}{|c|}{ I gennemsnit $10,9 \mathrm{~m}^{2}$} \\
\hline \multicolumn{3}{|c|}{ Opført, procentfordeling: } & \multicolumn{3}{|c|}{ Forsynet, procentfordeling: } \\
\hline Af træ & Som grundmuret & Total & Med skorsten & Uden skorsten & Total \\
\hline 84,9 & 15,1 & 100 & 61,8 & 38,2 & 100 \\
\hline \multicolumn{2}{|c|}{ Opført på, procentfordeling: } & \multicolumn{2}{|c|}{ Vandforsyning, procentfordeling: } & \multicolumn{2}{|c|}{ Spildevandsafledning, procentfordeling: } \\
\hline Piller & Fundament & Udenfor hus & I hus & Ingen & Sivebrønd m.m. \\
\hline 4,5 & 95,5 & 0,7 & 99,3 & 2,7 & 97,3 \\
\hline
\end{tabular}

Kilde: Henvisninger under Appendix VI.B.

\section{Forsyning}

Som i sommerhusbybæltet ved Kattegatkysten forsynedes sommerhusbyerne i kystbæltet ved Roskilde Fjords nord- og østside tidligt med elektricitet fra NESA. Mens sommerhusbyerne, der lå nærmere kystbæltets købstæder og stationsbyer, dels på Halsnæs sydside, dels ved Lille Kregme og Kregme strande, opnåede vandforsyning fra disses kommunale vandværker, tilvejebragtes vandværkerne og vandforsyningsledningsnettet i de mere isolerede sommerhusbyer, ved Ølsted og St. Havelse strande og Jyllinge, af de stedlige og grundejerforeninger. Foreninger, der, ved lokalkommunalt krav, krævedes oprettet ved de særlige udstykningsdeklarationer, der lagedes på ejendommene, og som de enkelte ejere blev forpligt til at blive medlem af; jf. APPENXIV VII.

I modsætning til kloakeringen i sommerhusbæltet ved Kattegatkysten gennemførtes kloakeringen senere og $\mathrm{i}$ et mindre omfang $\mathrm{i}$ sommerhusbyerne ved Roskilde Fjords kystbælte. Først i Jyllinge i løbet af 70 'erne som følge af sommerhusbyens forvandling til pendlersatellitby med helårsbeboede enfamiliehuse og i løbet af 80 'erne alene i sommerhusbyerne på Halsnæs sydside. Selv der hermed i efterkrigstiden ikke opnåedes den samme grad af kloakering, som ved Kattegatkysten, kom kloakeringen af kystbæltes sommerhusbyer dog til at omfatte 54 procent af dets sommerhuse. Den mindre halvdel af sommerhusene i kystbæltets sommerhusbyer forblev dermed i hele efterkrigstidsperioden ikke kloakeret, hvorved spildevandsafledningen her basredes på sivebrønde eller septiktanke på de enkelte ejendomme. Systemet blev dog så udbredt i perioden, at kun mindre end en procent af sommerhusene ikke blev tilsluttet sădanne spildevandsanlæg. ${ }^{37}$

Tabel III.24. Procentvis fordeling af ti største og andre producenter af sommertypehuse i sommerhusbyerne ved Roskilde Fjords østside, 1950-1973.

\begin{tabular}{|l|l|}
\hline Jeppesens Savværk & 24,6 \\
\hline Myresjö Huse & 17,2 \\
\hline Skarridsø Huse & 12,5 \\
\hline Västkust Stugan & 9,8 \\
\hline Trelleborg & 5,6 \\
\hline Scanda Huse & 3,1 \\
\hline Ganløse Huset & 2,7 \\
\hline Anneberg Hus & 2,4 \\
\hline Tectum & 2,2 \\
\hline Tàrnby Huset & 2,0 \\
\hline Andre & 17,9 \\
\hline Total & 100 \\
\hline Anm: Andre producenter omfatter 23 virksombeder. Kilde: & Henvisninger under Appendix VI.B. \\
\hline
\end{tabular}

Anm.: Andre producenter omfatter 23 virksomheder. Kilde: Henvisninger under Appendix VI.B. 

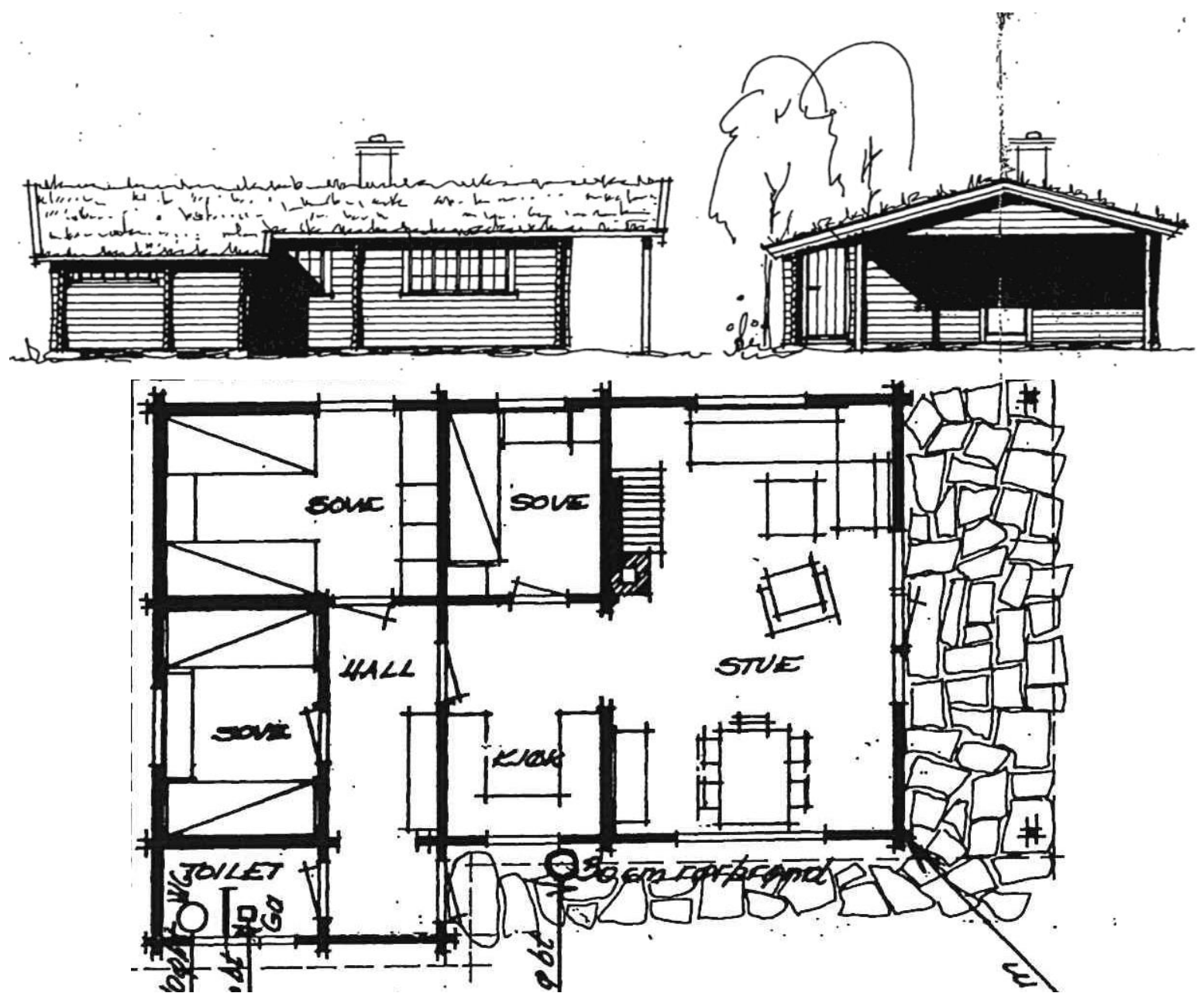

Ved siden af den indførsel af skandinaviske sommerhuse, som nogle danske virksomheder stod bag, importeredes i et vist omfang typesommerhus direkte fra hele Norden. Bl.a. dette fra 1968 fra norske Kjeldstad Sagbruk og Høvleri $i$ sommerhusbyen Lille Kregme (Halsnæs Kommune digitale byggesager, https://www.weblager.dk/).

\section{Erhverv}

Da en betydelig del af sommerhusbyerne i kystbæltet ved Roskilde Fjords nord- og sydside opstod i nærheden af bæltes købstæder og stationsbyer, generede sommerhusbydannelserne her i efterkrigstiden ikke et grundlang for en mere udbredt erhvervsudvikling. I sommerhusbyerne på Halsnæs sydside og ved Ølsted Strand var dagligvarehandlen således henvist til disse byer, mens der ved Lille Kregme og St. Havelse strande alene opstod en enkelt dagligvareforretning og ved Kregme Strand et mælkeudsalg. I Jyllinge fandtes allerede, da sommerhusbydannelsen blev påbegyndt en række byerhverv, og da disse ekspanderede i et meget betydeligt omfang i slutningen af 60 'erne og i den sidste efterkrigstid, blev denne erhvervsudvikling ikke genereret af sommerhusbebyggelsen, men af omdannelsen fra sommerhusby til satellitby.

Som ved sommerhusbybæltet ved Kattegatkysten kom forskellige etablissementer til at danne grundlag for andre funktioner end den primære sommerhusbosætning i sommerhusbyerne ved Roskilde Fjords nord- og østside. Kystbæltes to badehoteller blev således drevet videre i en årrække ind $\mathrm{i}$ efterkrigstiden, mens de feriekolonier, der allerede var etableret inden midten af det 20. århundrede forsatte virksomheden og endda i et udvidet omfang. Dette gjaldt bl.a. den senere selvejende institution Hvide Klint i det fredede og offentligt åbne rekreative område af samme navn i Lille Kregme Strand sommerhusby. 
Tilsvarende tiltræk bæltets sommerhusbyer forskellige former for mere arealintensiv landliggerbosætning. Allerede i 1963 etablerede motorcykelklubben Ariel en koloni af 17 små sommerhus i sommerhusbyen ved Store Havelse Strand. Grunden var ejet af klubben, mens de enkelte medlemmer selv stod for og bekostede opsætningen af de små huse, der samledes i en mindre husklynge, hvor fra der var adgang til koloniens store fællesareal ned Mod Roskilde Fjord. På initiativ af en privatmand oprettedes i tilknytning til Store Karlsminde sommerhusby på Halsnæs sydside i 1971 desuden Sølager Camping med toiletbygning og is- og pølsekiosk, og i det rekreative område Hvide Klint fik Hustligt Arbejderforbund samme år mulighed for at etablere en mindre koloni af ferieboliger for forbundets medlemmer. ${ }^{38}$

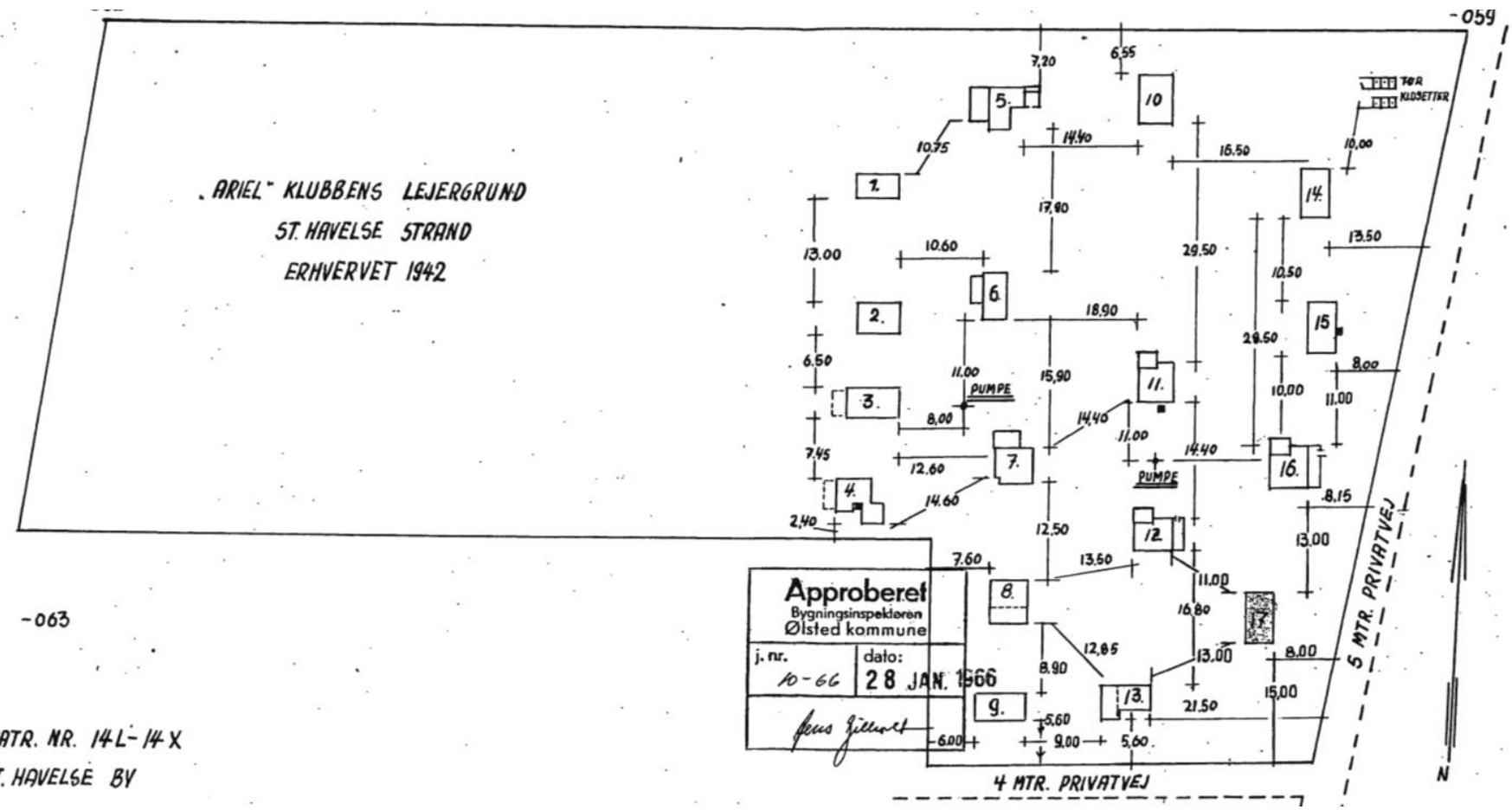

Også $i$ efterkrigstiden opførtes sommerhusene $i$ hovedstadsmetropolens sommerhusbyer af private. Udtagelser var f.eks. hytterne i Dansk Folkeferies feriebyer eller Motorcykellejrklubben Ariels kolonier af sma sommerhuse $i$ sommerhusbyen Store Havelse Strand. Klubben havde allerede i den første del af 50 'erne etableret en lille koloni med ni huse i sommerhusbyen Kulhuse, og udvidede yderligere aktiviteterne, da den i 1942 erhvervede en langt større strandgrund ved Roskilde Fjord ved det, der senere skulle blive til sommerhusbyen Store Havelse Strand. Fra 1963 til 1966 opstillede medlemmerne $i$ en mindre klynge 17 mindre sommerhuse med 2-3 værelser på grunden, der ud over en fællesbygning med toiletter og bad omfattede et betydeligt fællesareal ned mod fjorden (Frederikssund kommune digitale byggesager, https://www.weblager.dk/) 


\section{Hornsherreds sommerhusbyer}

Med den første efterkrigstids sommerhusboom var hverken Kattegatkysten eller kystbæltet langs Roskilde Fjords nord- og østside tilstrækkeligt il at opsuge periodens sommerhusbyggeri. Nye sommerhusbyer opstod derfor i det sidste kystnære områder i hovedstadsmetropolens åbne opland: Hornsherred. Selv om Hornsherred i det væsentligste blev upåvirket af dannelsen af hovedstadsmetropolen i det 20. århundredes første halvdel, og dermed ikke undergik den urbaniseringsproces, der generede de bymæssige servicefunktioner, som var en af forudsætningerne for sommerhusbydannelserne andre steder i metropolens åbne opland, bevirkede halvøens betydelige ubebyggede- og berørte kysstrækninger både til Roskilde Fjord vestside og Isefjordens østside, at Hornsherred trods sin vanskeligere trafikale tilgængelighed $\mathrm{i}$ århundredets sidste halvdel, ud over pendlerbolig i parcelhusomrăderne ved eksisterende landbyer, integreredes i hovedstadsmetropolens som et sommerhusbyområde. Et område, der kom til at omfatte det næststørste volumen af sommerhuse i metropolens åbne land; jf. Appendix VI.C.

\section{Lokalisering}

Som en $30 \mathrm{~km}$ landstrakt halvø, adskilt af Roskilde Fjord mod øst og Isefjorden mod vest, uden jernbaneforbindelser og med vanskeligere tilkørselsforhold end til andre steder af hovedstadsmetropolens åbne opland, udgjorde Hornsherred i midten af det 20.århundred den fjerneste og mest isolerede del af metropolen. Den nordligste del af halvøen var kendetegnet af store skovområder og sandede markjord, mens den sydligere del henlå som et åbent og ofte kuperet agerland med kirkesognelandsbyer, underliggende landsbyer, klynger af husmandssteder og en række større godser, der tidligere havde været en del af det kronens domæne eller i adellig besiddelse.

\section{Hornsherred - et udkantsområde i hovedstadsmetropolen}

Hornsherred blev gennemskåret af en nord-sydgående landevej, der udgik fra Frederikssund og ved hovedgården Biltris, syd for Skibby, delte sig i to: En i et videre forløb langs Roskilde Fjord til halvøens rod ved Lindenborg ud fra Lejre Vig, hvorfra der var forbindelse til hovedlandevejen København-Roskilde-Holbæk-Kalundborg. En i et løb nærmere Isefjorden med tilslutning til forannævnte hovedlandevej syd for K. Sonnerup. Herudover blev Hornsherred gennemskåret af en række større sognekommunale veje. Dels en mellem Frederikssund og Kulhuse på halvøens nordspids, dels et større antal mellem dets kirkesognelandsbyer, hvoraf flere samlede sig i Skibby.

Med betydelige afstande til de nærmeste købstæder, Frederikssund, Roskilde og Holbæk, havde Skibby med sin centrale placering i midt af Hornsherred i den del af det 19. århundrede udviklet sig til en egentlig landevejsby, der i starten af der følgende århundrede, i 1916, rummede 816 indbyggere, et betydeligt antal håndværksvirksomheder, detailhandelsforretninger, et andelsmejeri, en kro, en dampmølle samt en markedsplads med to årlige kreaturmarkeder. Ud over kirke og kommunal skole, alderdomshjem og vandforsyning, udgjorde Skibby samtidig Hornsherreds servicemæssige centrum med læge, apotek, privat realskole, en amtskommunal arbejds- og forsørgelsesanstalt og et statsligt optagelseshjem for værgerådsbørn. Med disse erhverv udgjorde de bymæssige i 1916, med 32,4 og 34,6 procent på henholdsvis industri-handel og servicevirksomhed, to tredjedele af sognets erhvervsbeskæftigelse, mens landbruget alene tegnede sig for en tredjedel.

Ved åbningen af Den midtsjællandske Jernbane gennem Hornherred i 1924 forstærkedes udviklingen i Skibby, der fik samme karakter som landets øvrige større statsionsbyer. ${ }^{39}$ Selv om jernbanen nedlagdes i 1936, medførte den forøgede lastbiltrafik og den private rutebilsdrift, der var påbegyndt i 20 'erne og fra Frederikssund, Roskilde og Holbæk havde 
endestation i Skibby, at byen kunne fastholde denne position. I midten af det 20. århundrede var byens befolkning siden 1916 forøget med 53 procent, hvoraf 84,9 procent var beskæftiget i byerhverv, fordelt med 44,4 procent i industri- og håndværk og 40,5 i serviceerhverv, og alene godt 15 procent i landbruget. Ud over de virksomheder, der allerede var etableret i 1916, var der frem til i 1950 opstået: Både bank og sparekasse, et fjerkræslagteri, en pelsdyrfarm, et andelskølehus, en biograf og et pensionat. Inden for offentlig service var der opført et nyt alderdomshjem, etableret en teknisk skole, en telefoncentral og et posthus, mens alderdomshjemmet var blevet erstattet af et nyt og betydelig større og den private realskole kommunaliseret.

Selv om Skibby fik et folketal og erhvervsgrundlag, der kom i nærheden af landets mindste købstæder, havde det øvrige og fuldt rurale Hornsherred en så fjernt beliggenhed fra hovedstadsmetropolens centrale dele, at befolkningen herfra i midten af det 20. århundrede ikke nævneværdig grad havde tilflyttet halvøen, der alene var købstadsopland til Frederikssund mod nord, Roskilde mod syd og i nogen grad Holbæk mod vest. Trods halvøens betydelige og i øvigt helt uberørte naturattraktioner havde den, udover sommerhusbyen i Kulhuse og enkelte meget spredte bebyggelser med fătallige sommerhus, kun i et begrænset omfang tiltrukket metropolbefolkningen til rekreative ferie- og fritidsudflugter eller anden landliggerbosætning. ${ }^{40}$

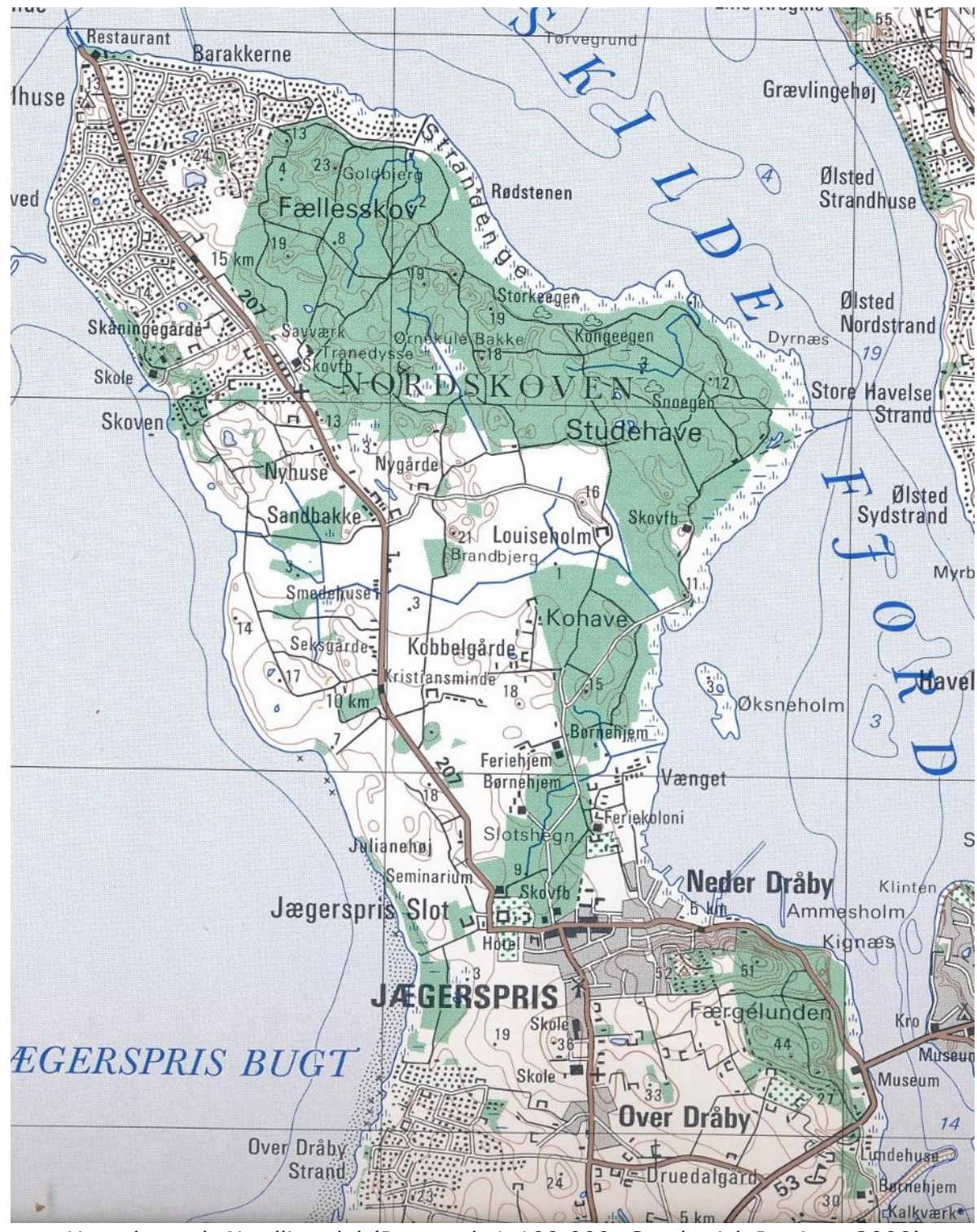

Hornsherred: Nordlige del (Danmark 1:100.000, Geodætisk Institut, 2000) 


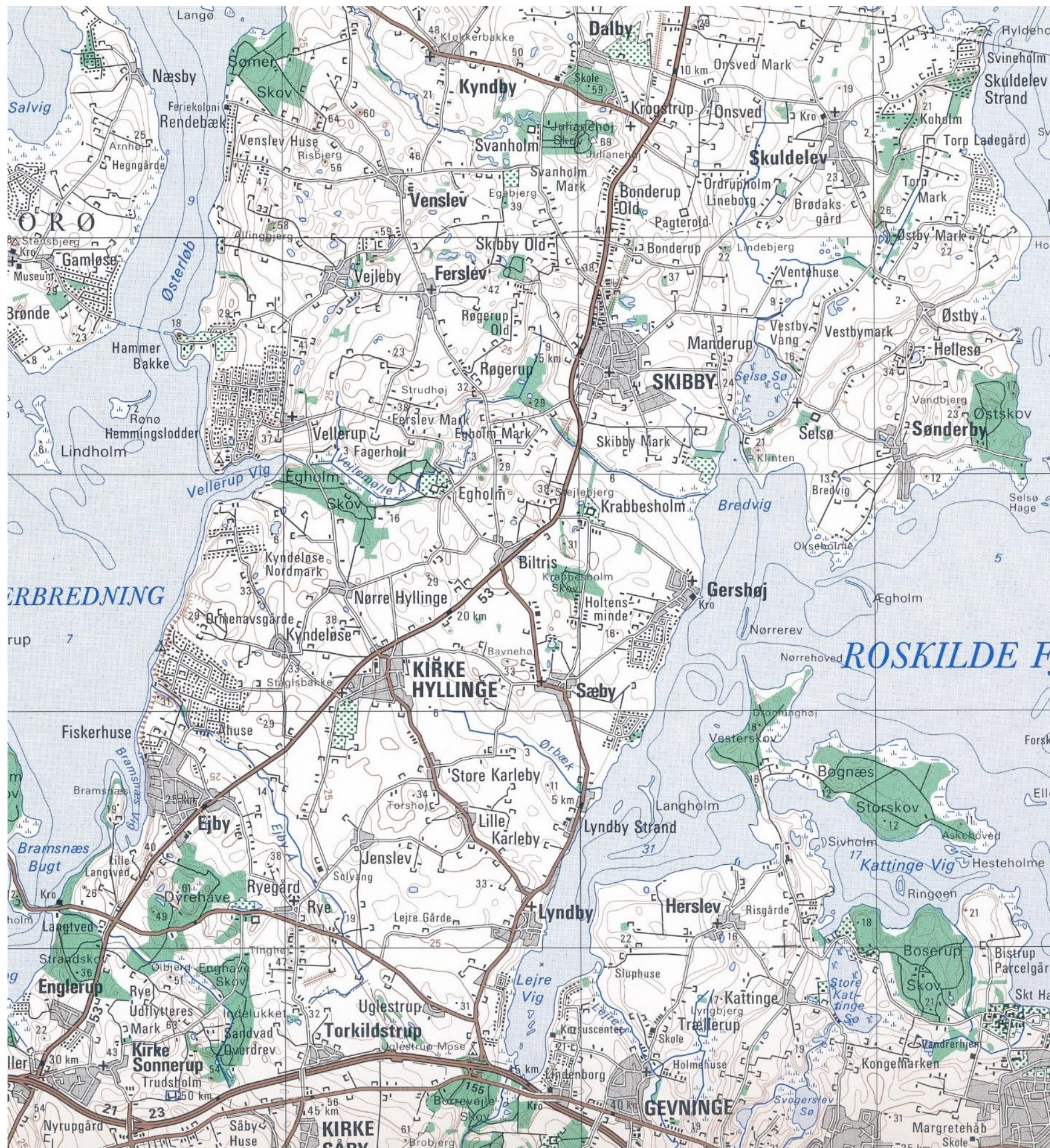

Hornsherreds: Mellemste og sydlige del (Danmark 1:100.000, Geodætisk Institut, 2000)

\section{Hornsherreds sommerhusbyer}

Selv om Hornherred udgjorde den mest isolerede del af hovedstadsmetropolens åbne opland, og ikke kunne byde på samme gode vej- og kollektivtrafikale forbindeler og et større udbud af byerhverv i fiskerlejer, stationsbyer og købstæder som i Kattegatkystens sommerhusbybælte eller i sommerhusbyerne i Roskildes Fjords kystbælte, betegnede efterkrigstiden alligevel et markant vendepunkt. 


\section{Volumen og fordeling}

Med den attraktion som Hornsherreds hidtil uberørte fjordkyster udgjorde opførtes i perioden 1950-1990 ikke mindre end 9.042 sommerhuse, svarende til 226 pr. år, på halvøen (tabel III.25). Fordelt med 80,3 procent af hele periodens samlede mængde sommerhus, eller 316 sommerhuse pr. år, i den første efterkrigstid, og 19,7 procent, svarede til 111 sommerhuse pr. $\mathrm{a} r$, i den sidste efterkrigstid. Med 22,3 procent af hovedstadsmetropolens samlede mængde opførte sommerhuse i hele efterkrigstidsperioden, fordelt med 22,1 procent i den første efterkrigstid og 22,8 i den sidste del af perioden, blev Hornsherred det område i byregionens åbne land, hvor koncentrationen af sommerhusbyer i metropolen blev næststørst. En koncentration, der som følge af de langt mindre omfattende pendlersatellitbydannelser i Skibby og andre af Hornherreds større landsbyer ikke i samme grad integrerede halvøens sommerhusbyer blandt hovedstadsmetropolens ydre bydannelser, men i stedet gjorde den til metropolens mest udtalte sommerhusbyopland.

Tabel III.25. Procentvis fordeling af sommerhuse samt udstyknings- og bebyggelsesperioder i Hornsherreds sommerhusbyer, 1950-1990.

\begin{tabular}{|l|l|l|l|l|l|}
\hline \multirow{2}{*}{ Sommerhusby } & \multicolumn{2}{|l|}{ Procentandel af antal sommerhuse } & Udstykningsperiode & \multirow{2}{*}{ Bebyggelsesperiode } \\
\cline { 2 - 4 } & $1950-1973$ & $1974-1990$ & $1950-1990$ & & \\
\hline Tørslev Hage & 2,8 & 2,9 & 2,8 & $1964-1973$ & $1963-1990$ \\
\hline Gerlev Strandpark & 0,0 & 1,7 & 0,3 & 1984 & $1985-1990$ \\
\hline Skuldelev Strand & 1,6 & 1,5 & 1,6 & $1955-1972$ & $1965-1990$ \\
\hline Hyllingeris & 0,0 & 10,6 & 2,1 & 1976 & $1977-1990$ \\
\hline Ved Sønderby & 0,9 & 1,3 & 1,0 & 1965 & $1965-1968$ \\
\hline Gershøj Strand & 2,8 & 4,5 & 3,1 & $1960-1974$ & $1961-1990$ \\
\hline Strandlund & 1,6 & 2,6 & 1,8 & $1961-1974$ & $1962-1990$ \\
\hline Lyndby Strand & 0,7 & 1,6 & 0,8 & $1959-1974$ & $1959-1985$ \\
\hline Uglestrup Strand & 1,0 & 0,8 & 1,0 & $1961-1965$ & $1961-1988$ \\
\hline Lindenborg & 3,6 & 0,7 & 3,0 & $1964-1968$ & $1965-1990$ \\
\hline Englerup & 1,3 & 0,6 & 1,1 & $1959-1964$ & $1960-1985$ \\
\hline Ejby Strand & 4,0 & 1,6 & 3,5 & $1950-1972$ & $1951-1990$ \\
\hline Kyndeløse Sydmark & 10,5 & 10,4 & 10,4 & $1959-1975$ & $1959-1990$ \\
\hline Kyndeløse Nordmark & 1,6 & 0,8 & 1,4 & $1963-1964$ & $1963-1990$ \\
\hline Vellerup Sommerby & 3,8 & 27,8 & 8,6 & $1963-1972$ & $1967-1990$ \\
\hline Hammervang & 0,8 & 0,6 & 0,8 & 1963 & $1964-1990$ \\
\hline Rendebæk & 0,8 & 0,8 & 0,8 & 1963 & $1963-1990$ \\
\hline Dalby Huse & 8,9 & 4,8 & 8,0 & $1950-1973$ & $1959-1990$ \\
\hline Over Dråby Strand & 14,1 & 3,6 & 12,0 & $1950-1971$ & $1951-1990$ \\
\hline Kulhuse & 39,2 & 20,8 & 35,9 & $1950-1975$ & $1950-1990$ \\
\hline Total & 100 & 100 & 100 & $1950-1984$ & $1950-1990$ \\
\hline
\end{tabular}

Kilde: Henvisninger under Appendix VI.C.

Det omfattende sommerhusbyggeri i Hornsherred gav ud over en meget kraftig udbygning af den eksisterende sommerhusby i Kulhuse anledning til dannelse af 19 nye sommerhusbyer på halvøen: Sytten opstået i den første efterkrigstid og to i den sidste. Med 82,4 procent af hele efterkrigstidsperioden nyopførte sommerhuse blev koncentrationen af sommerhusbyer signifikant større ved halvøens Isefjordskyst og med alene 17,6 procent lang mindre ved Roskilde Fjords kyst (tabel III.26). I den første efterkrigstid tegnede sommerhusbyerne ved Isefjorden sig for 85,1 procent af samtlige nye sommerhus og Roskilde Fjordsiden sig alene for 14,9 procent, mens fordeleingen i den sidste efterkrigstid forrykkede sig en smule til fordel af sommerhusbyerne ved Hornherred østkyst. I denne periode kom sommerhusbyer ved Roskile Fjord til omfatte 28,6 procent af mængden af nye sommerhuse, mens byerne ved Isefjroden alene tegnede sig or 71,4 procent.

\section{Isefjordskysten}

Som ved sommerhusbyerne i andre dele af hovedstadsmetropolens sommerhusbyer blev det også kystnærheden, der blev den drivende lokaliseringsfaktor ved Hornsherreds sommerhusbydannnelser, men at en så betydelig del af den første efterkrigstids sommerhusbyer opstod ved halvøens Isefjordskyst, var betinget af dens særlige attraktioner, den tidlig landliggerbosætning og ældre sommerhusbebyggelse, der var opstået her. Ved fjordens nordlige del henlå kysterne således over ganske betydelige strækninger som 
sandstrande, ligesom de her var mere åbne og havde vide udsyn over vandspejlet til Odsherred i det fjerne. I de midterste og sydlige del af Hornsherred blev Isefjorden ganske vist smallere, og kysten fik over visse strækninger karakter af åbne engarealer, men til gengæld kunne der her bydes på mere intime og dermed klassiske danske fjordmiljøer med enestående udsigter til småøer og små vige og bugter.

Tabel III.26. Procentvis fordeling af sommerhuse i Hornherreds sommerhusbyer, 1950-1990.

\begin{tabular}{|c|c|c|c|c|}
\hline & $1950-1973$ & & $1974-1990$ & $1950-1990$ \\
\hline Ved Roskilde Fjord, nordlige del & 5,3 & & 18,3 & 7,8 \\
\hline Ved Roskilde Fjord, sydlige del & 9,6 & & 10,3 & 9,8 \\
\hline Ved Isefjorden, sydlige del & 17,3 & & 13,6 & 16,5 \\
\hline Ved Isefjorden, midterste del & 5,3 & & 29,6 & 10,1 \\
\hline Ved Isefjorden, nordlige del & 62,5 & & 28,2 & 55,8 \\
\hline Total & 100 & & 100 & 100 \\
\hline Total & \begin{tabular}{l|l} 
& 100
\end{tabular} & 100 & 1950-1984 & $1950-1990$ \\
\hline
\end{tabular}

Kilde: Henvisninger under Appendix VI.C.

Attraktioner, der var dog var særlig udtalte i Hornsherreds nordligste del og navnlig ved Kulhuse, hvor der var udsigter til de fjorde der dannede halvøen, og hvor udsigten på Isefjordssiden var særlig vid, og visse steder samtidig gav mulighed for havkig til Kattegat. Da en større sognekommunal landevej forbandt Kulhuse med Frederikssund, hvorfra der var landevej og fra 1873 tillige jernbaneforbindelse til hovedstaden, fik Kulhuse, som Kattegatkysten og ved Jyllinge, da også umiddelbart efter århundredskiftet en tidlig landliggerbosætning i pensionater for hovedstadsoverklassen og i den første del af mellekrigstiden en mindre koloni af sommervillaer for samme befolkningslag. Disse sommerbosætninger dannede grundlag for, at den stedlige købmandshandel suppleredes med en købmandsforretning og brugsforening, og med åbningen af regelmæssig amtskommunalt koncessioneret privat rutebilsforbindelse til Frederikssund blev Kulhuse samtidig tilgængelig for dem, der ikke havde et motoriseret køretøj eller råd til individuelt at lade sig befordre til vogns. Afgørende faktorer for, at der i den sidste mellemkrigstid etableredes et antal sommerlejre- og kolonier for hovedstadens børn og unge, og indlogeringsmuligheder for bredere befolkningslag, og at der i tilknytning hertil etableredes et bageri, en yderligere købmandshandel og en droske- og vognmandsforretning.

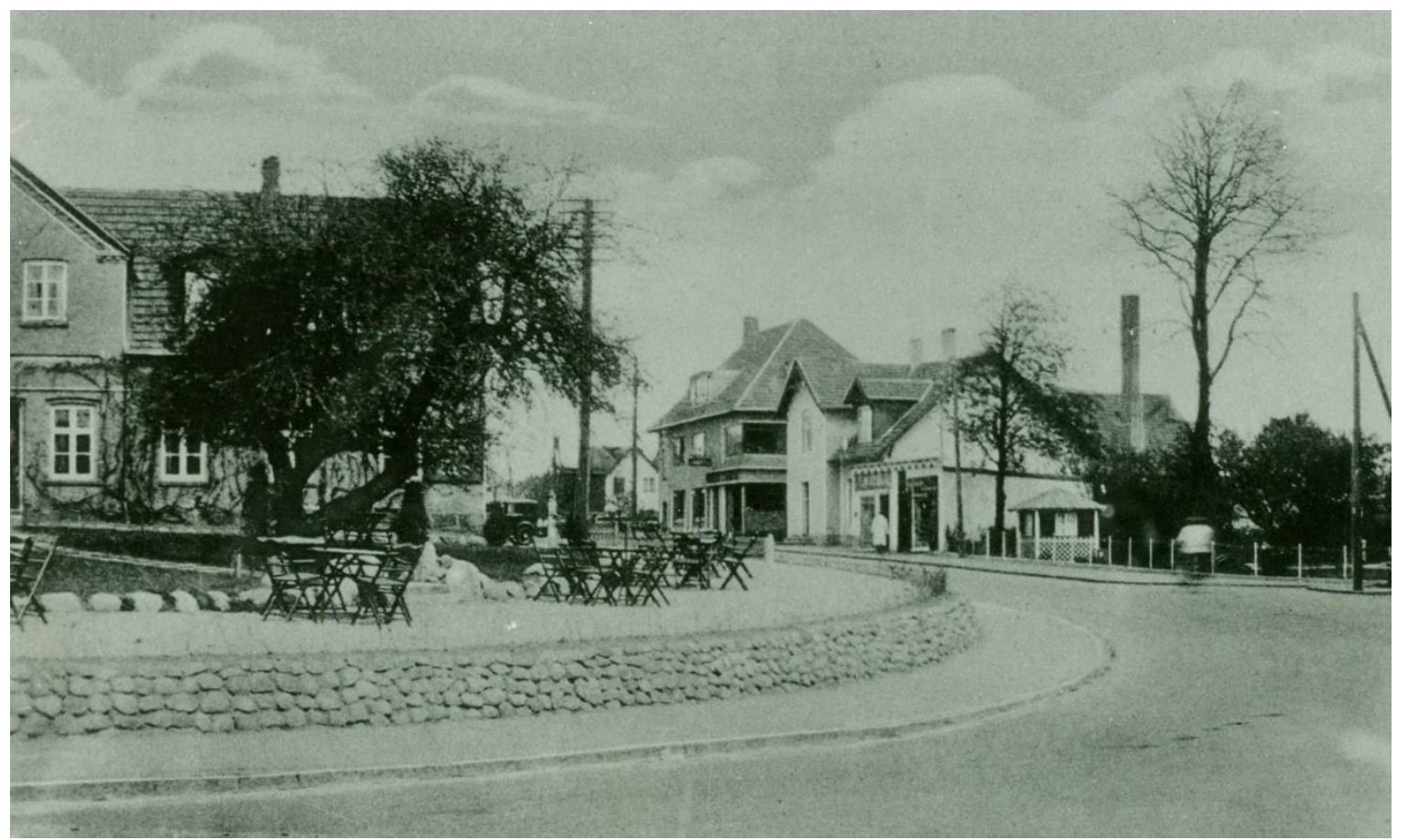

Hovedgaden i landvejsbyen Skibby i midten af 30'erne. Som landevejsby og i en kort periode også som stationsby, blev Skibby Hornsherreds eneste egentlige by. (Foto 1950, Frederikssund Lokalhistoriske Arkiv, Skibby Arkiv) 
Sammen med de særlige kyst- og naturmæssige attraktioner, forudsætningen for at der $\mathrm{i}$ Kulhuse fra slutningen af 30 'erne gennemførtes udmatrikuleringer af et mindre antal sommerhusparceller, der 10 àr efter fulgtes af en større udstykning og fra 1950, i resten af dette årti, i 60 'erne og frem til midten af 70 'erne masseudstykninger, der gjorde Kulhuse til Hornsherreds største sommerhusby og samtidig en af de største sommerhusbyer i hovedstadsmetropolens åbne opland. En meget omfattende sommerhusbydannelse, der syd for det store militære øvelsesterræn på den nordligst del af det nordlige Hornsherred i samme periode, og navnlig i 60 'erne, genererede meget betydelige sommerhusudstykninger- og bebyggelser i Over Dråby Strand og Dalby Huse, der allerede i den første efterkrigstid blev Hornsherreds næstørste og fjerdestørste sommerhusbyer.

Som følge af den gradvise udfyldning af sommerhusbyerne i kystområdet på det nordvestlige Hornsherred forsatte sommerhusudstykningerne- og bebyggelserne længere mod syd langs Isefjordens kystbælte. Med tilkørsel fra landevejen Frederikssund-Skibby og rutebilsforbindelser fra Frederikssund opstod således på den midterste del af halvøens Isefjordskyst ved udstykninger i perioden 1963-1972 dels to mindre sommerhusbyer Rendebæk, der som følge af den tidligere færgerute til Orø frem til 1951 havde haft en færgekro, som havde fungeret som badehotel og forlystelsessted, og Hammervang, dels syd herfor den større sommerhusby Vellerup Sommerby. En sommerhusby, der fik en særlig kraftig vækst med nye udstykninger og yderligere byggeri i den sidste efterkrigstid, som følge af den fuldstændige udbygning af sommerhusbyerne nord for.

Samtidig med de betydelige sommerhusudstykninger- og bebyggelser på Hornherreds nordlige og siden midterste del indledtes, med de gode tilkørselsforhold fra hovedlandevejen København-Roskilde-Holbæk og den derfra førende landeveje K. Sonnerup-Skibby samt flere rutebilsforbindelser fra Roskilde, større udstykninger og bebyggelser i løbet af 50 'erne på halvøens sydlige del ud til Isejorden. Først ved Ejby Strand, hvor der fra slutningen af 30 'erne ud til kysten var opstået en mindre sommerhusenklave, og hvor Bramsnæsvig Badehotel og Andssvageforsorgens plejecenter Bramsnæsvig havde etableret sig i henholdsvis 1933 og 1947. Senere syd for, uden tidligere landliggerbosætning, ved Englerup og nord for på Kyndeløse Sydmark. Som følge af de forsatte sommerhusudstykninger- og bebyggelser ved hele Hornsherreds Isefjordskyst opstod i 60' erne nord for sommerhusbyen på Kyndeløse Nordmark samtidig med, at sommerhusbyerne Ejby Strand og Kyndeløse Sydmark udvidedes så meget, at de i den første efterkrigstid kom til at udgøre halvøens tredje- og femtestørste sommerhusbyer.

Med den første efterkrigstids lokalisering af sommerhusbyer ved Hornsherreds Isefjordskyst opstod ikke mindre end 80 procent af halvøens samlede sommerhusbyggeri i seks meget betydelige sommerhusbyer. Alene over 60 procent i sommerhusbyerne Kulhuse, Over Dråby Strand og Dalby Huse og de øvrige knapt 20 procent i sommerhusbyerne Vellerup Sommerby, Kyndeløse Sydmark og Ejby Strand. De sidste knap 5 procent fordelte sig på de mindre sommerhusbyer Rendebæk, Hammervang, Kyndeløse Nordmark og Englerup.

\section{Roskilde Fjord-siden}

I forhold til og som følge af den tidlige og meget betydelige koncentration af sommerhusbyer ved Hornsherreds Isefjordskyst, udstykkedes og bebyggedes sommerhusbyerne ved halvøens Roskilde Fjord-side først i løbet af 60 'erne og ind i de følgende årtier. Sommerhusbyer, der tillige blev langt mindre og spredtliggende, og i den første efterkrigstid kun kom til at omfatte godt 15 procent af peirodens sommerhuse i Hornsherred. På nær en mindre ældre sommerhusbebyggelse i Lyndby havde den sydlige del af fjordsiden ikke været genstad for nogen form for landliggerbosætning. Kyststrækningen var her for det mest kendetegnet af engarealer, men med de smukke udsigter over vigene ved bunden af Roskilde Fjord og med gode tilkørselsforhold fra hovedlandevejen, København-Roskilde-Holbæk, og senere Holbækmotorvejen, den derfra førende landevej Roskilde-Skibby og flere rutebilsforbindelser fra 
Roskilde, blev disse østlige dele af Hornsherred mere attraktive i takt med opfyldningen af sommerhusbyerne ved Isefjordskysten.

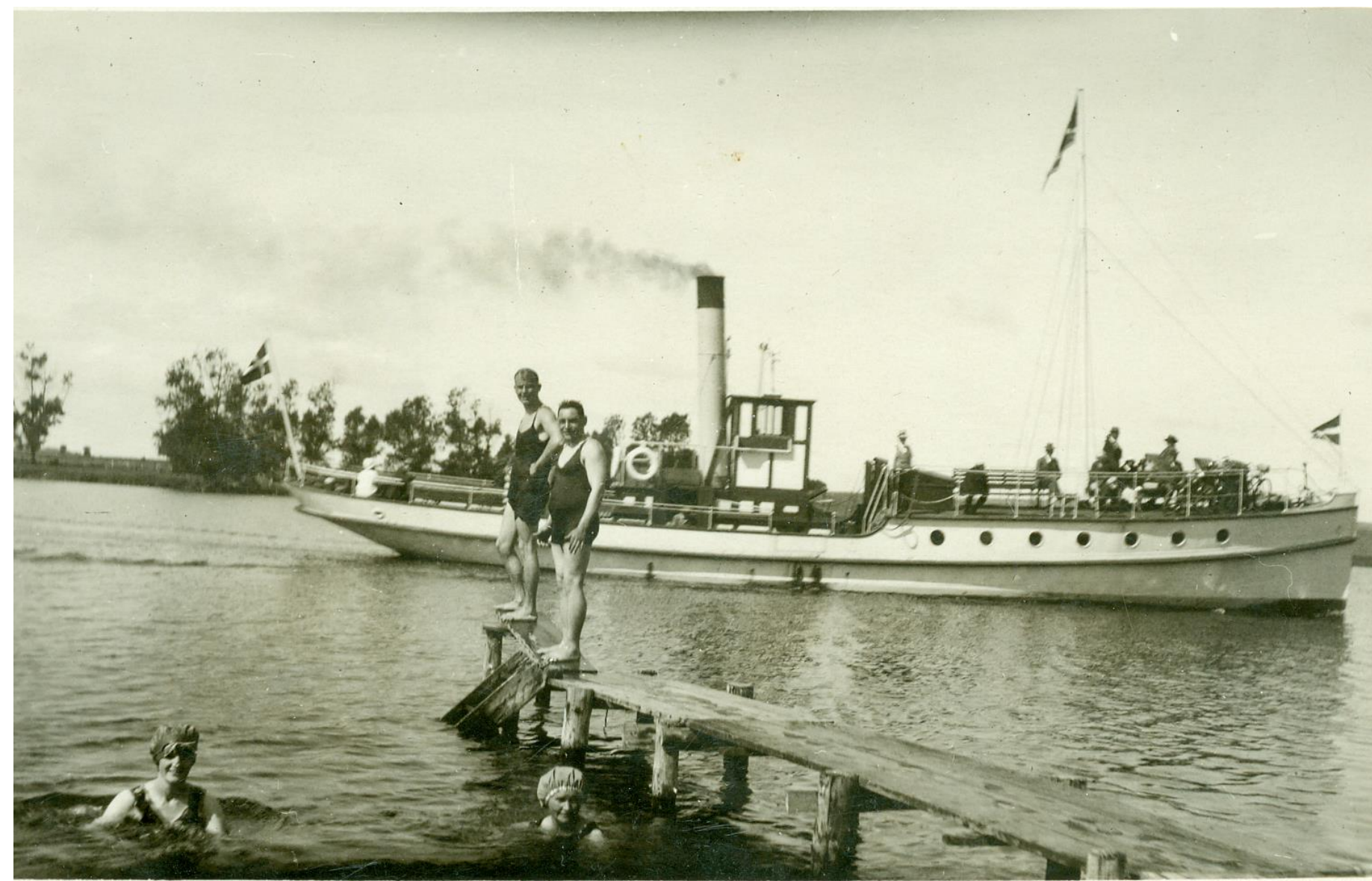

Med kro og anløbsplads for damprutebåden på strækningen ruten Roskilde-Lyndby-Sælsø blev Gershøj et udflugtsmål særlig for borgere i Roskilde. Driften indstilledes dog i 50 'erne, og på nær nogle fa pensionater og kroer og to mindre ældre badehoteller, fik Hornsherreds langstrakte fjordkyster ikke den overklasselandliggerbosætning, som

kendetegnede Kattegatkysten og i nogen grad også Roskilde Fjords nord- og østside. En bosætningsform, som havde udgjort en af flere lokaliseringsaktorer bag disse sommerhusbyområder, men som pa nær sommerhusbyen Kulhuse ikke fik betydning for beliggenheden af sommerhusbyerne i Hornsherred (Foto 1925, Frederikssund Lokalhistoriske Arkiv, Skibby Arkiv).

Således opstod her op gennem den første halvdel af 60'erne fem sommerhusbyer med knap 10 procent af de sommerhuse, der opførte i Hornsherred i den første efterkrigstid. Således den relativ store sommerhusby Gershøj Strand syd for Gershøj landsby og fiskerleje, der omfattede kro og anløbsplads for dampskibsruten Roskilde-Lyndby-Sælsø, som var i drift fra 1910 til en gang i 50 'erne og et yndet udflugtsmål fra Roskilde. Syd herfor de mindre sommerhusbyer Strandlund og Lyndby og Uglestrup strande og på den anden side af Lejre Vig den større sommerhusby ved Lindenborg, hvor Borrevejle Idræts- og lejrplads med større idrætsanlæg og vandrehjem allerede havde etableret sig i 1931.

Med længere tilkørsler ad biveje fra landevejen Frederikssund-Skibby, kun en rutebilsforbindelse fra Frederikssund, kyststrækninger ofte alene med tilstødende engarealer og mindre storslåede udsigter opstod fra den sidste del af 60 'erne de sidste knapt fem procent af de sommerhuse, der opførtes i Hornsherred i den første efterkrigstid, i tre sommerhusbyer ved den nordligere del af Roskilde Fjord. Fra nord i den relativt store sommerhusby Tørslev Hage, syd for i den noget mindre Skuldelev Strand, hvor de allerede i midten af 50 'erne var opstået en lille klynge sommerhuse og helt mod syd den lille sommerhusby, der opstod syd for landsbyen Sønderby, og med den videre udsigt over fjorden og kort afstand til Selsø og 
Østskov nok havde den mest attraktive beliggenhed i forhold til de øvrige sommerhusbyer ved Hornsherreds Roskilde Fjordkyst. ${ }^{41}$

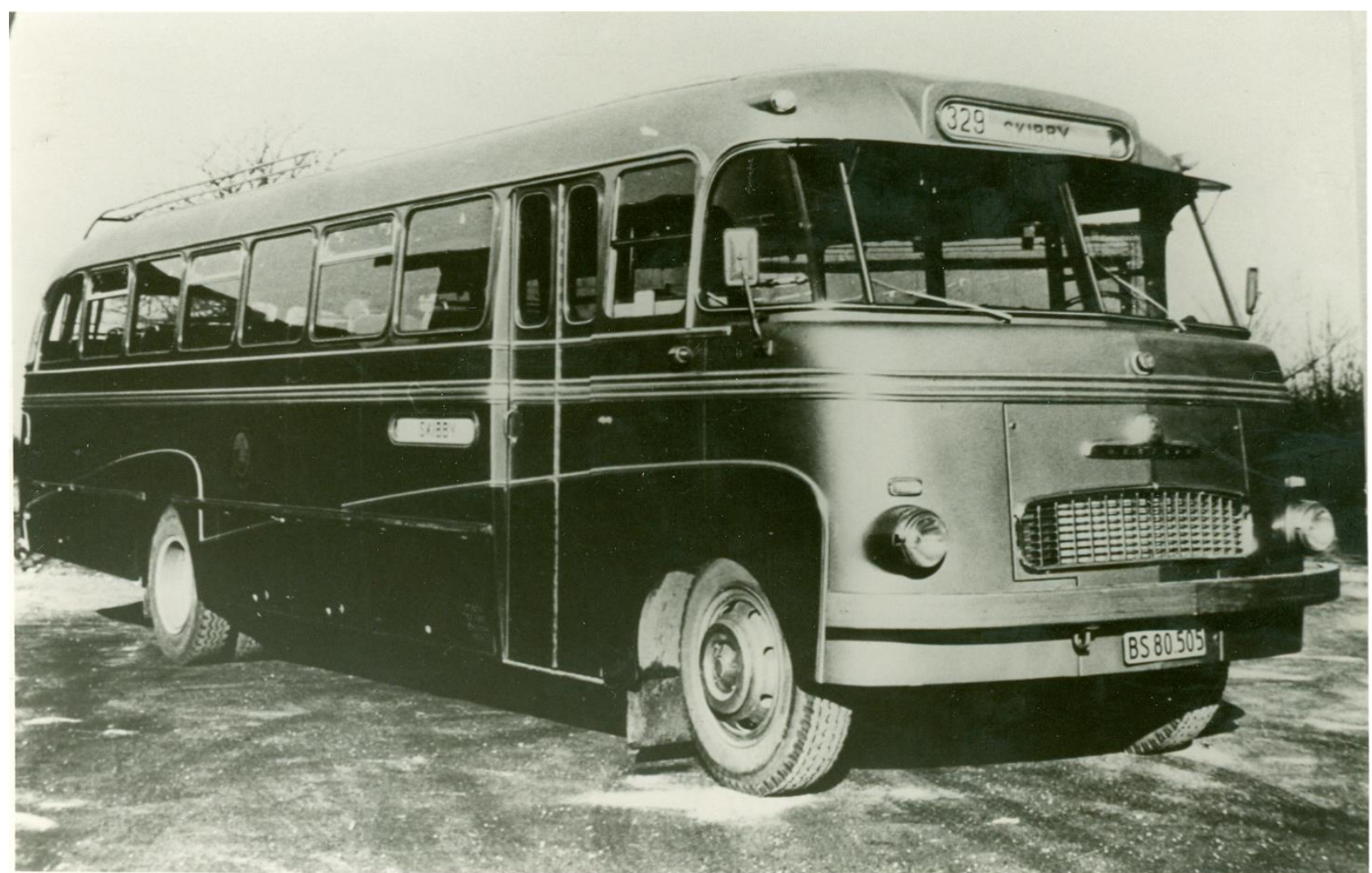

Hornsherreds yderlige og isolerede beliggenhed i hovedstadsmetropolens abne opland, relativt mindre attraktive strande og mere lukkede kystlandskaber, var afgørende for den udeblevne tidlige overklasselandliggerbosætning og den senere sommerhusbydannelse. Hertil kom de i forhold til andre steder i hovedstadsmetropolens abne land relativt vanskelige vejtilkørselsforhold og svagt udbyggede kollektive trafikforbindelser. Her den enlige rutebil, der i 50' - og 60 'erne p̊̊ ruten Frederikssund-Skibby betjente hele den nordøstlige del af Hornsherred (Foto 1950, Frederikssund Lokalhistoriske Arkiv, Skibby Arkiv)

\section{Bystruktur}

Som følge af de ganske indgribende fredninger og rekreative arealerhvervelser, der tidligt gennemførtes i Hornherred og dem, der fulgte efter i 60'erne og den sidste efterkrigstid, fik sommerhusbydannelser her en anden karakter end ved Kattegatkystens sommerhusbælte og i nogen grad sommerhusbyerne ved Roskilde Fjords nord- og østside; jf. Kapitel 9. Selv om sommerhusbyerne ved Sønderby og Gershøj og Ejby strande smeltede sammen med de stedlige landsbyer, lykkedes det gennem disse regionale fredningsdispositioner i Hornsherred op gennem efterkrigstiden i det væsentligste at skabe endeligt afgrænsede sommerhusbyer, der adskiltes fra hinanden af meget betydelige områder med åbent land. Til gengæld kunne hverken disse dispositioner eller de lokalkommunale forsøg på at gennemføre en vis byplanlægning ikke dæmme op for, at Hornsherred i efterkrigstiden fik meget store sommerhusbyer, og at disse visse steder fik en udflydende karakter og bredte sig langt ind $\mathrm{i}$ baglandet; jf. APPENDIX VII.

\section{Bebyggelse}

Hornsherred kom således på nordvestsiden i efterkrigstiden til at omfatte to store sommerhusbyer med tæt ved halvdelen af periodens sommerhusbyggeri på halvøen og tre større sommerhuse fordelt langs hele Isefjordskysten med i nærheden af 30 procent af dette byggeri (tabel III.27). De øvrige godt 20 procent af efterkrigstidsperiodens sommerhusbyggeri fordeltes stort set ligeligt dels på fire mellemstore sommerhusbyer, hver med en ved den 
sydlige del af Isefjordskysten og ved den nordlige del af Roskilde Fjordkysten og to ved dennes sydlige del, dels 11 mindre sommerhusbyer fordelt med fire ved den midterste og sydlige del af Isefjordskysten, fire ved den nordlige del af Roskilde Fjordkysten og tre ved dens sydlige del.

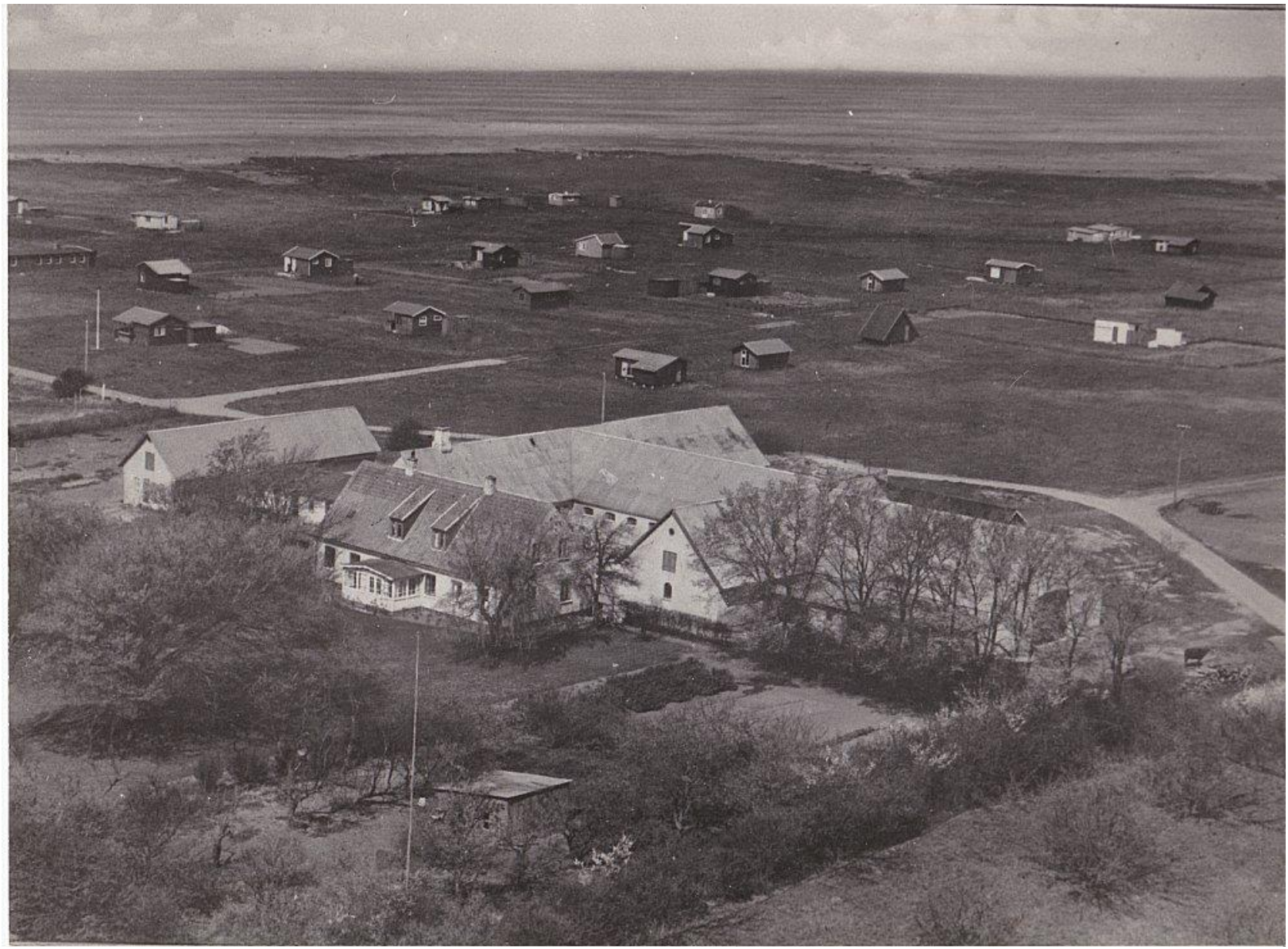

Samtidig med de videre udparcelleringer i den ældre sommerhusby Kulhuse begyndte i den første del af 50 'erne større sommerhusudstykninger andre steder langs Hornsherreds Isefjordskyst. Her de første sommerhusbebyggelser til det, der skulle blive til sommerhusbyen Over Dråby Strand. I forgrunden den gård, hvis jorde lagde grund til den nye sommerhusby (Stillet til rådighed af Henrik Clausen, Frederiksberg Stadsarkiv)

Af Hornsherreds 20 efterkrigstidssommerhusbyer var alene en, Kulhuse, med 36 procent af periodens sommerhusbyggeri, dannet ved en udvidelse af en eksisterende sommerhusby, mens de resterende 19 sommerhusbyer, med godt 60 procent af sommerhusbyggeriet, var opstået på bar mark. Heraf tre, med knapt 7 procent af sommerhusbyggeriet, i tilknytning nærmeste landsby, og 16, med 57 procent af dette byggeriet, i det åbne land.

Tabel III.27. Procentvis fordeling efter sommerhusby størrelse, Hornsherred, 1950-1990

\begin{tabular}{|l|l|l|}
\hline & $\begin{array}{l}\text { Procentvis fordeling efter antal } \\
\text { huse }\end{array}$ & Antal sommerhusbyer \\
\hline Store somerhusbyer (over 1.000 huse) & 48,3 & 2 \\
\hline Større sommerhusbyer (500-999 huse) & 27,2 & 3 \\
\hline Mellemstore sommerhusbyer (200-499) & 12,7 & 4 \\
\hline Mindre sommerhusbyer (Mindre end 199) & 11,8 & 11 \\
\hline Total & 100 & 20 \\
\hline
\end{tabular}

Kilde: Henvisninger under Appendix VI.C.

Såvel i sommerhusbyen Kulhuse, der udbyggedes på grundlag af en allerede opstået sommerhusby, som i de 19 af Hornsherreds øvrige sommerhusbyer, som opstod på bar mark, 
fik bebyggelsens udbredelsen en række fællestræk. Udstykningerne og den efterfølgende bebyggelse opstod således helt ud til og langs kyslinjens eng- eller strandområder, og bredte sig derfra tidsmæssigt forskudt successivt som koncentriske lag langs større eller mindre omfattende systemer af side-, tvær- og parallelveje til og langs oprindelige, forlængede eller nynalagte sekundærbiveje, markveje, eller primærbiveje, sognekommunale biveje, der udenfor sommerhusbyen og dermed længere inde i landet førte frem Hornsherreds gennemgående landeveje eller andre primærbiveje med forbindelse til disse landeveje.

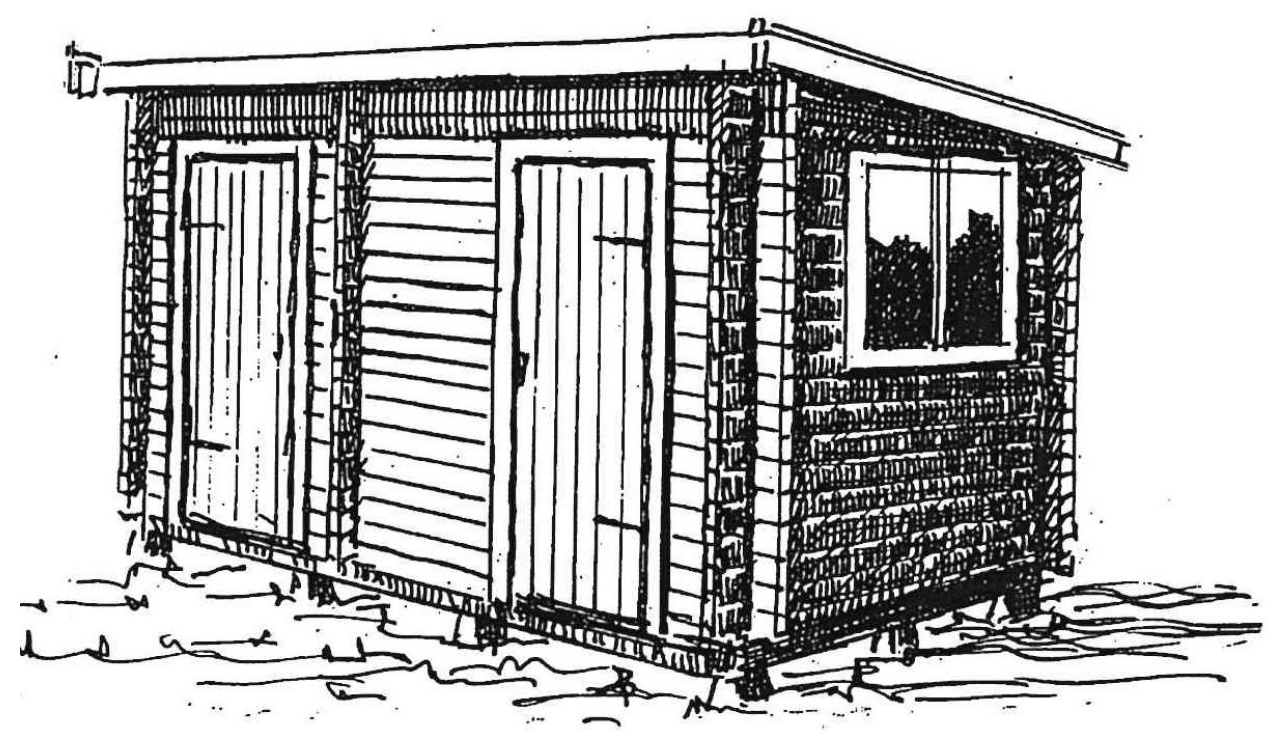

Som helhed blev sommerhusbyggeriet i Hornsherred det mindst prætentiøse. Det blev bl.a. her, det blev mest almindeligt, at de nye grundejere startede med at opsætte skure inden, der blev råd til et egentligt sommerhus. Et kombineret lokums- og redskabsskur, som dette fra Jeppesen Savværk opsat i sommerhusbyen Ejby Strand i 1962, kunne også bruges til ophold i regnvejr og overnatning (Lejre Kommune digitale byggesager, https://www.weblager.dk/)

I en betydelig del af Hornsherreds sommerhusbyer, helt overvejende store, større og mellemstore - Over Dråby Strand, Dalby Huse, Hammervang Vellerup Sommerby, Kyndeløse Sydmark og Nordmark, Sønderby og Tørslev Hage- svarende til 44 procent af Hornsherreds efterkrigstidssommerhusbyggeri, fik bebyggelsesstrukturen imidlertid karakter af forholdsvis korte bebyggelser langs kystlinjen, der til gengæld bredte sig i betydeligt omfang ind $\mathrm{i}$ baglandet. Modsat de mellemstore og mindre sommerhusbyer -Rendebæk, Ejby Strand, Englerup, Lindeborg, Uglerup Strand, Lyndby Strand, Strandlund, Gershøj Strand, Hyllingeris og Skuldelev Strand - der med 14 procent af periodens sommerhusbyggeri fik form af langstrakte kystbebyggelser, der ikke i større omfang bredte sig ind i baglandet. I en særklasse indgik sommerhusbyen Kulhuse, der med de restende knapt 40 procent efterkrigstidsperiodens sommerhusbyggeri blev en stærkt koncentreret bebyggelse, som ved Hornsherred nordspids fra kysterne ved såvel Roskilde Fjord som Isefjorden bredte sig ind baglandet til et stort og sammenhængende byområde.

Mens der i sommerhusbyerne ved Roskilde Fjords nord- og østside kun etableredes mindre fællesarealer, og alene de regionale fredningsdispositioner kompenserede herfor, lykkedes det særlig på grundejerforeningernes initiativ og steder med lokalkommunale byplanmæssige bestemmelser at skabe sådanne arealer i Hornsherred somerhusbyer. Kun i fire sommerhusbyer, med godt fem procent af halvøens sommerhuse fra efterkrigsperioden, bebyggedes bakkedrag, plantager og andre arealer på en sådan måde, at de eneste tilbageværende friarealer var mose- og engområder, der var så sumpede, at de var uegnet til byggeri og i øvrigt også til at udgøre reelle fællesarealer. I fire sommerhusbyer, med en ottendel af Hornsherreds sommerhuse, lykkedes til gengæld at etablere mindre fællesarealer 
ved kysten, i nogle tilfælde med jollehavn og badebro, eller som i Vellerup Sommeby at opnå sådanne arealer ved udlæg af gennemgående smalle stibælte, spredte ubebyggede områder i selve bebyggelsen og et større kystnært fællesområde ved dennes sydspids.

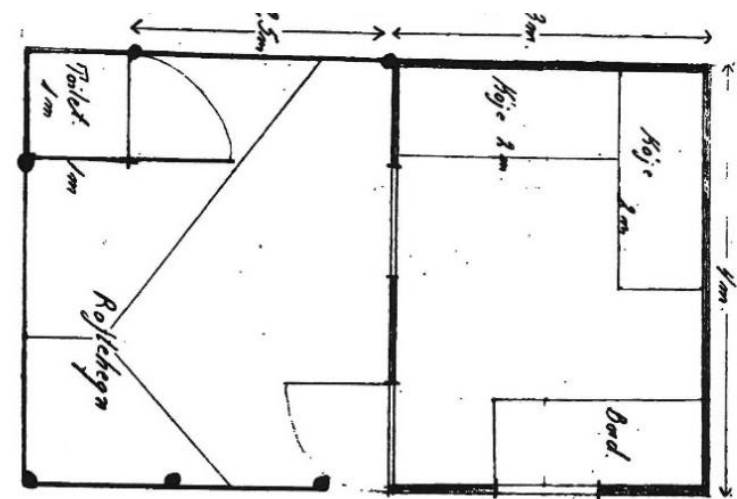

Hornsherred blev også det sommerhusbyområde, hvor selvbyg var mest udbredt. Her fra sommerhusbyen Tørslev Hage et karakteristisk eksempel fra 1968. Et $12 \mathrm{~m}^{2}$ hus med køjer og køkkenbrod, den klassiske indhegnede gårdsplads og i dettes ene hjørne et lokum (Frederikssund Kommune, digitale byggesager, https://www.weblager.dk/)

Hornsherreds øvrige sommerhusbyer, med godt 80 procent af halvøens sommerhuse, tillagedes endog ganske betydelige fællesarealer. F.eks. i den sydlige del af sommerhusbyen Lindeborg vellykket gennem udlæg af et stort fællesareal mellem de til dette stødende tungeforme bebyggelser, der samtidig adskiltes fra hinanden af andre mindre fællesområder med gennemgående stiforløb, eller bebyggelsesopdelende og gennemgående fællesarealer med stisystemer som i sommerhusbyerne ved Kyndeløse Sydmark og Nordmark. I sommerhusbyerne Dalby Huse og Over Dråby Strand i form af brede strandområde langs hele kystlinjen og hertil i førstnævnte med plantage syd for byen og i sidstnævnte et større område med legepladser og fodboldbane i tilknytning til det kystnære fællesareal. Ved Kulhuses via et oprindeligt fredet og senere sognekommunalt udlagt rekreative områder i sommerhusbyens nordlige del og ellers langs kysternes stand- og engarealer. ${ }^{42}$
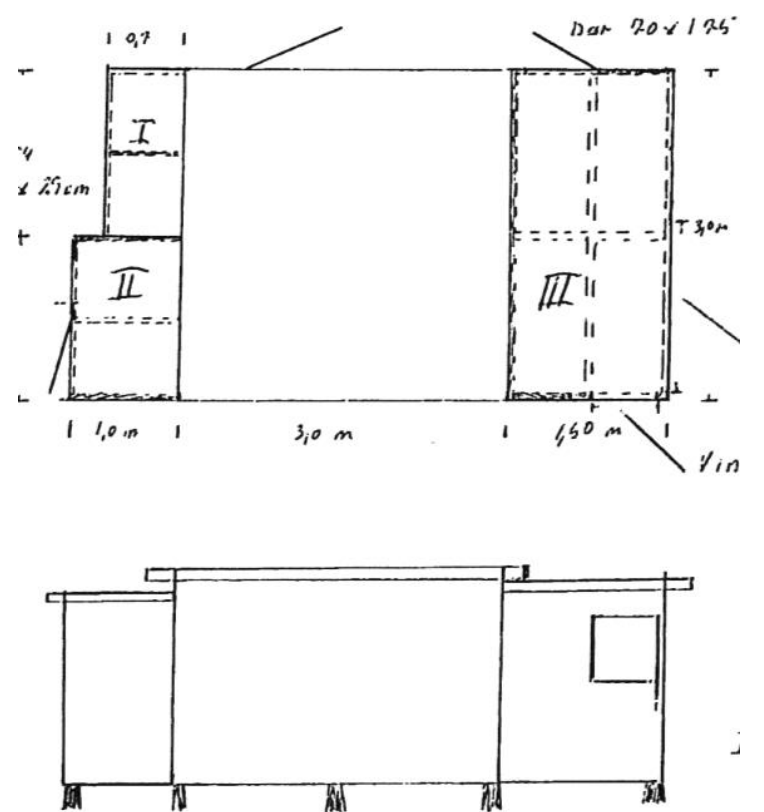

Successive udvidelser af sommerhuse blev desuden særlig udbredt i sommerhusbyerne i Hornsherred. I dette tilfælde fra 1968 i sommerhusbyen Tørslev Hage, havde ejeren ved selvbyg opført en hovedbygning (III), et redskabsskur (II) og et lokum (I) og forbandt bygningerne med plankeværker, hvorved der opstod et lukket gardrum. Næst skridt blev, også ved selvbyg at omdanne dette gårdrum til en egentlig bygning, således at alle bygninger kom til at udgøre en bygningskrop (Frederikssund Kommune, digitale byggesager, https://www.weblager.dk/) 


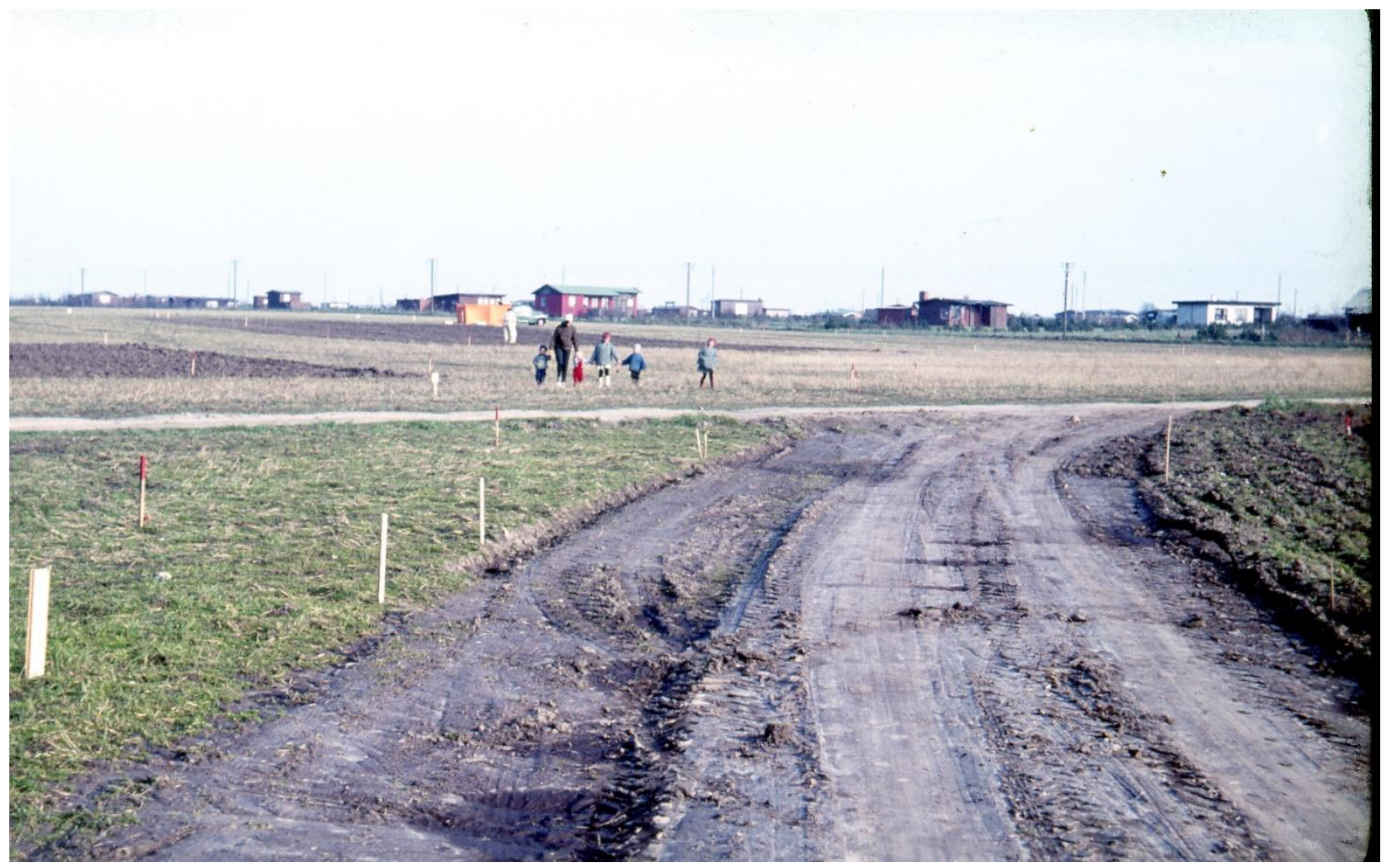

Et parti fra nogle af de store udstykninger, der gennemførtes op gennem 60'erne i sommerhusbyen Over Dråby Strand. Pælene markerer de udstykkede grunde og de plørende veje, som udstykkeren havde uldlagt, giver et eksempel på de udfordringer, grundejerforeningerne skulle løse, når grundene bebyggedes i større omfang (Stillet til rådighed af Henrik Clausen, Frederiksberg Stadsarkiv).

\section{Social sammensætning}

Skønt gruppen af selvstændige og funktionærer i forhold til sammensætningen af erhvervsbeskæftigede i hovedstadsmetropolens første efterkrigstid også var stærkt overrepræsenteret og arbejdere tilsvarende underrepræsenterede som førstegangssommerhusejere i sommerhusbyerne i Hornsherred, blev den sociale sammensætning af disse her, som ved Roskilde Fjords nord- og østside, mere jævn end i sommerhusbybæltet ved Kattegatkysten (tabe III.28). I forhold til fjordkysten sommmerhusbyer indgik andelen førstegangsejende arbejdere med samme andel i Hornsherred, mens andelen fra laget af selvstændige og funktionærer lå omkring to procent henholdsvis højere og lavere i Hornsherred end på den modsatte side af Roskulde Fjord. Den mest signifikant forskel mellem de to regionale sommerhusbyområder udgjorde den lavere repræsentation af større selvstændige og navnlig højere funktionærer i sommerhusbyerne i Hornsherred, hvis førstegangssommerhusejere som helhed må have ligget på et noget lavere indkomstniveau end ved Roskilde Fjords nord- og østside.

Et forhold, der bevirkede, at andelen af førstegangssommerhusejere med bopæl i velhaverforstæderne på Nordegen udgjorde en lavere andel i Hornherreds sommerhusbyer, og at disse var mere jævnt fordelt over de øvrige forstadsegne (tabel III. 29). At andelen af førstegangssommerhusejere med bopæl uden for hovedstadsmetropolens centrale dele lå højere i Hornsherred end på den anden side af Roskilde Fjord, var betinget af, at de relativt korte afstand til Frederikssund, Roskilde og Holbæk. Denne større andel af førstegangsommerhusejere fra nogle af de omkringliggende købstæder og det forhold, at sommerhusbyerne i Hornsherred opstod og udbyggedes senere i den første efterkrigstid end dem ved Rosilde Fjords nord- og østside, førte til, at en noget større andel af førstegangssommerhusejere på halvøen havde vinterbopæl i et enfamiliehus. Netop den periode, hvor andelen af boliger i etagebebyggelser i hovedstadsmetropolen faldt, mens andelen af enfamiliehuse tilsvarende forøgedes. 
Tabel III.28. Procentvis social sammensætning af førstegangssommerhusejere i Hornsherred, 1950-1973, og i hovedstadsmetropolen, 1950 og 1970.

\begin{tabular}{|c|c|c|c|c|c|c|}
\hline \multirow[t]{3}{*}{ Stilling } & \multirow{3}{*}{\multicolumn{2}{|c|}{$\begin{array}{l}\text { Sommerhusejere, } \\
1950-1973\end{array}$}} & \multicolumn{4}{|c|}{$\begin{array}{l}\text { Hovedstadsmetropolens erhvervsbeskæftigede } \\
\text { Befolkning }\end{array}$} \\
\hline & & & \multicolumn{2}{|c|}{1950} & \multicolumn{2}{|c|}{1970} \\
\hline & & & Hovedstaden & Forstæder & Hovedstaden & Forstæder \\
\hline Større selvstændige & 4,8 & & & & & \\
\hline Mindre selvstændige & 16,5 & & & & & \\
\hline Selvstændige, total & & 21,3 & 11,7 & 17,4 & 7,1 & 9,5 \\
\hline Ledende funktionærer & 6,9 & & & & & \\
\hline Akademisk uddannede funktionærer & 6,8 & & & & & \\
\hline Højere funktionærer, i alt & 13,7 & & & & & \\
\hline Øvrige funktionærer & 42,1 & & & & & \\
\hline Funktionærer, total & & 55,8 & 33,0 & 24,2 & 42,6 & 44,6 \\
\hline Faglærte arbejdere & 18,6 & & & & & \\
\hline Ufaglærte arbejdere & 4,3 & & & & & \\
\hline Arbejdere, total & & 22,9 & 53,3 & 58,4 & 50,0 & 44,1 \\
\hline Total & 100 & 100 & 100 & 100 & 100 & 100 \\
\hline
\end{tabular}

Kilde: Henvisninger under Appendix VI.C. Bro: Hovedstadsmetropolen- den danske byregion 2020, s. 547-548.

Som ved såvel Kattegatkysten som Roskilde Fjords nord- og østside udgjorde førstegangsommerhusejere fra laget af højere funktionærer og større selvstændige i den første efterkrigstid en større andel ved de mest kystnære dele af Hornsherreds sommerhusbyer end på halvøen som helhed. Samme højindkomst lag af førstegangsommerhusejere, der i højere grad havde vinterbopæl i forstæderne på Nordegnen og i enfamiliehuse, opnåede samtidig en højere andel i Hornsherreds mindre sommerhusbyer ved Sønderby og Roskilde Fjords sydlige del, den midterste del ved Isefjorden, hvor der var et lille udbud af grunde med attraktiv beliggenhed ved eller i kort afstand til kystlinjen, i den store sommerhusby Kulhuse og de større og mellemstore sommerhusbyer Vellerup Sommerby og Lindenborg. Disse havde en særlig attraktiv beliggenhed, nogle en tidligere landliggerbosætning, sommer- og ferielejre samt et større udbud af forretninger og servicetilbud. Hertil kom bedre tilkørselsforhold og rutebilsforbindelser.

Tabel III.29. Procentvis fordeling af bopælsområde og boligform for førstegangssommerhusejere i Hornsherred, 1950-1973, og i hovedstadsmetropolen, 1950 og 1970.

\begin{tabular}{|l|l|l|l|}
\hline & Sommerhusejere & Hele hovedstadsmetropolens befolkning \\
\hline Bopæl i: & $1950-1973$ & 1950 & 1970 \\
\hline Hovedstaden & 51,7 & 61,9 & 41,8 \\
\hline Nordegnen & 11,8 & 12,2 & 13,5 \\
\hline Nordvestegnen & 9,5 & 3,8 & 8,5 \\
\hline Vestegnen & 19,5 & 7,0 & 15,4 \\
\hline Andet & 7,5 & 15,1 & 20,8 \\
\hline Total & 100 & 100 & 100 \\
\hline Etagebolig & 61,9 & 82,3 & 74,7 \\
\hline Enfamiliehuse & 38,1 & 17,7 & 25,3 \\
\hline Total & 100 & 100 & 100 \\
\hline
\end{tabular}

Anm: Fordelingen på etageboliger og enfamiliehuse omfatter alene hovedstaden og forstadsegnene

Kilde: Henvisninger under Appendix VI.C. Statistiske Årbog for København, Frederiksberg m.m., 1952, s. 1, 55, 191-

192 og 198. https://www.kk.dk/sites/default/files/migrated/sc/1972-aarbog.pdf

https://www.kk.dk/sites/default/files/migrated/sc/1975-aarbog.pdf

De lavere indkomstlag af førstegangssommerhusejere fra arbejderklassen og gruppen af øvrige funktionærer og mindre selvstændige, hvis vinterbopæl i højere grad var fordelt på selve hovedstaden og de øvrige forstadsegne og bestod af en lejlighed i etagebyggeriet, kom derimod i den første efterkrigstid til at udgøre en større andel i de store, større og mellemstore sommerhusbyer ved Isefjordens nordlige og sydlige del og Roskilde Fjords nordlig del.

Sommerhusbyer med en mindre attraktiv beliggenhed, med et mindre udbud af forretninger og servicetilbud og af et sådant volumen, at udbuddet af parceller var så stort, at det sammenlagt bidrog til, at grundpriser her blev mindre, hvilket gjorde det muligt at erhverve en byggegrunde med mindre attraktiv beliggenhed længere fra kystlinjen til lavere pris. 
Herudover havde disse sommerhusbyer vanskeligere tilkørselsforhold og ofte kun en rutebilsforbindelse. ${ }^{43}$
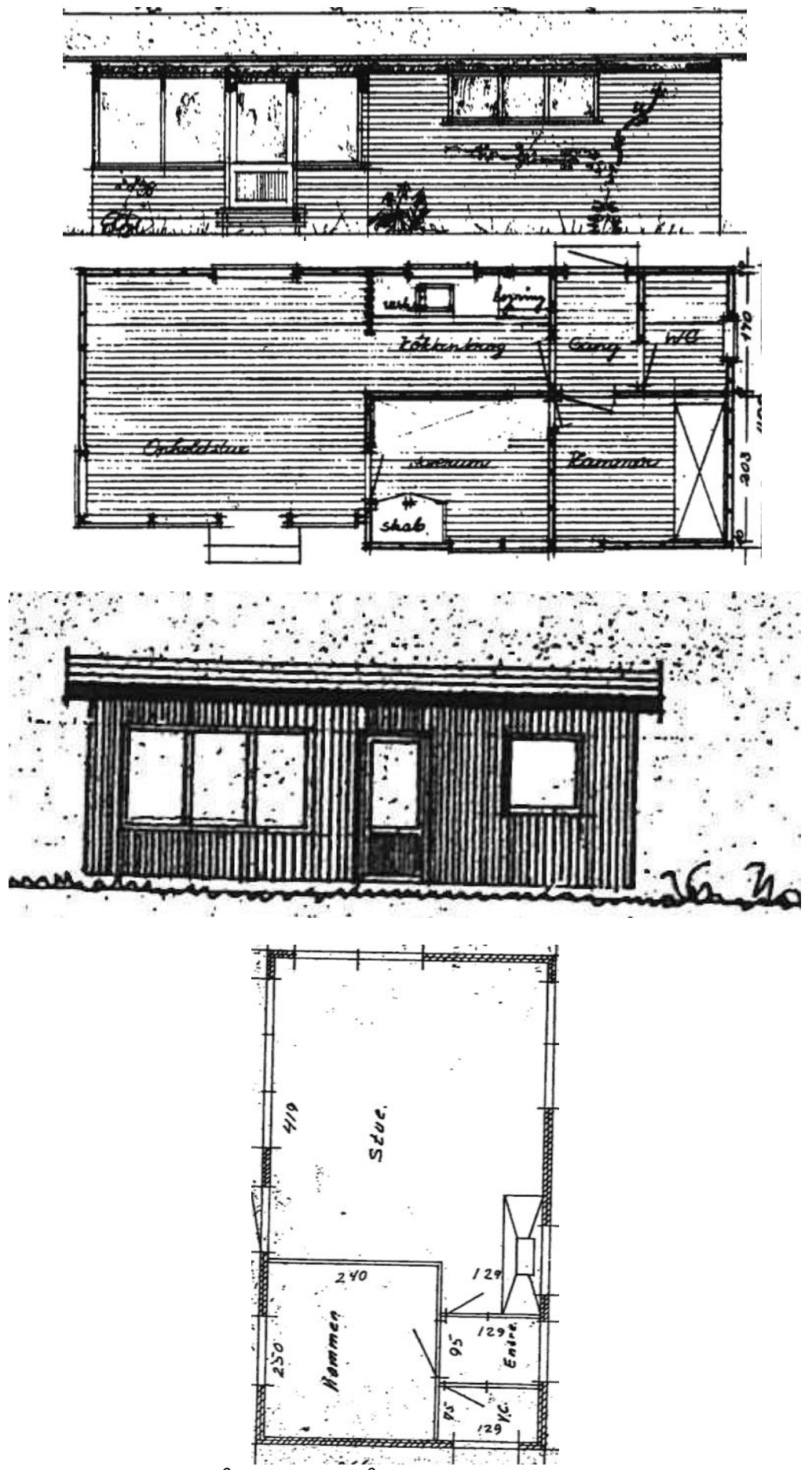

Hornsherred blev også det sommerhusområde, hvor små og billige typesommerhuse blev mest udbredt. Øverst et 37 $m^{2}$ Tarnbyhus fra 1967 med grundplan. Neden for et $28 \mathrm{~m}^{2}$ Ganløse Hus med grundplan fra det følgende ar. Begge huse blev opført i sommerhusbyen Gershøj (Frederikssund Kommune digitale byggesager, https://www.weblager.dk/)

\section{Sommerboliger standard}

Skilte sommerhusbyerne i Hornsherred i den første efterkrigstid for så vidt den sociale sammensætning af førstegangssommerhusejere sig i nogen grad ud fra sommerbyerne ved Roskilde Fjords nord- og østside, gjaldt det tillige paramenterne for sommerhusstandarden (tabel III.30). Med det lavere indkomstniveau blandt førstegangssommerhusejerne i 
Hornsherreds sommerhusbyer var sommerhusene her med et gennemsnitareal på 47,2 $\mathrm{m}^{2}$ noget mindre end de i snit 50,1 $\mathrm{m}^{2}$ store sommerhuse i sommerhusbyerne ved Roskilde Fjords nord- og østlige kystbælte, og rummede flere sommerhuse med 1-3 værelser end på den anden side af fjorden, hvor de 4-5 værelses var mere fremherskende. Langt flere af Hornsherreds sommerhuse var uden indendørs toilet, bad, fuldisolering, opvarmning via en skorsten, og manglede et selvstændig køkken, indlagt vand og autoriseret spildevandsafledning i form af sivebrønd eller septiktank.

Tabel III.30. Parametre for sommerhusstandarden i Hornsherred, 1950-1973.

\begin{tabular}{|c|c|c|c|c|c|}
\hline \multirow[t]{2}{*}{ Opført, i procent: } & Som selvbyg & Af bygmester & Med arkitektbistand & Af byggefirma & Total \\
\hline & 13,3 & 18,8 & 1,6 & 66,3 & 100 \\
\hline \multicolumn{6}{|c|}{ Rumfordeling, i procent: } \\
\hline 1 rum & 2 rum & 3 rum & 4 rum & 5 el. fl. Rum & Total \\
\hline 2,9 & 27,3 & 57,2 & 10,1 & 2,5 & 100 \\
\hline \multirow[t]{2}{*}{ Toilet, i procent: } & Udenfor huset & I huset & Total & \multirow{2}{*}{\multicolumn{2}{|c|}{$\begin{array}{l}27,6 \text { procent med bad. } \\
1,9 \text { procent uden køkken }\end{array}$}} \\
\hline & 22,9 & 77,1 & 100 & & \\
\hline Areal: & \multicolumn{2}{|c|}{ Mellem $10-120 \mathrm{~m}^{2}$.I gennemsnit $47,2 \mathrm{~m}^{2}$} & Udvidelser: & \multicolumn{2}{|c|}{ I gennemsnit $12,8 \mathrm{~m}^{2}$} \\
\hline \multicolumn{3}{|c|}{ Opført, procentfordeling: } & \multicolumn{3}{|c|}{ Forsynet, procentfordeling: } \\
\hline Af træ & Som grundmuret & Total & Med skorsten & Uden skorsten & Total \\
\hline 86,6 & 13,4 & 100 & 50,9 & 49,1 & 100 \\
\hline \multicolumn{2}{|c|}{ Opført på, procentfordeling: } & \multicolumn{2}{|c|}{ Vandforsyning, procentfordeling: } & \multicolumn{2}{|c|}{ Spildevandsafledning, procentfordeling: } \\
\hline Piller & Fundament & Udenfor hus & I hus & Ingen & Sivebrønd m.m. \\
\hline 13,2 & 86,8 & 4,3 & 95,7 & 5,8 & 94,2 \\
\hline
\end{tabular}

Kilde: Henvisninger under Appendix VII: Hornsherred

Den lavere sommerhusstandard i Hornsherreds sommerhusbyer manifesterede sig tillige ved at langt flere sommerhuse var opført på piller og som selvbyg eller typesommerhuse, hvor de mere prisbillige fra Jeppesens Savværk, Ganløse Huset, Tectum og Tårnby Huset var mere udbredte i modsætning til de dyrere fra f.eks. Myresjö, Skarridsø og Västkust Stugan (tabel III.31) Endelig havde en større andel af førstegangssommerhusejere i Hornsherreds sommerhusbyer opført et skur eller en garage til redskaber og kortvarig overnatning inden, der efter nogle år blev midler til at opføre et egentligt sommerhus.

Tabel III.31. Procentvis fordeling af ti største og andre producenter af sommertypehuse i Hornherred, 1950-1973.

\begin{tabular}{|l|l|}
\hline Jeppesens Savværk & 25,8 \\
\hline Myresjö Huse & 15,5 \\
\hline Västkust Stugan & 12,8 \\
\hline Skarridsø Huse & 8,5 \\
\hline Ganløse Huset & 4,9 \\
\hline Tectum & 4,2 \\
\hline Tårnby Huset & 3,9 \\
\hline Anneberg Hus & 3,6 \\
\hline Scanda Huse & 3,5 \\
\hline Trelleborg Hus & 3,2 \\
\hline Andre & 14,1 \\
\hline Total & 100 \\
\hline
\end{tabular}

Anm: Andre producenter omfatter 44 virksomheder. Kilde: Henvisninger under Appendix VII: Hornsherred.

Som i andre af hovedstadsmetropolens sommerhusbyer, blev dem på Hornherred tillige i den første efterkrigstid kendetegnet af betydelige forskelle i henseende til sommerhusstandarden. I de sommerhusbyer, hvor højindkomstlaget af højere funktionærer og større selvstændige udgjorde en større andel af førstegangssommerhusejerene end i Hornsherreds sommerhusbyer i gennemsnit, blev sommerhusstandarden ikke overraskende i disse højere end på halvøen som heldhed. I disse havde sommerhusene således et større areal, og rummede flere med 3-5 værelser, toilet, bad, skorsten, fuldisolering, indlagt vand og autoriseret spildevandsafledning. Samtlige sommerhuse var opført på støbt fundament og i højere grad med arkitektbistand eller som typesommerhuse i den dyre ende.

Modsat Hornsherreds sommerhusbyer med et lavere indkomstniveau blandt førstegangsommerhusejere, hvor relativt flere sommerhuse havde arealer, der var mindre end 
på halvøen som gennemsnit, og 1-3 værelser, ligesom flere ikke var forsynet med køkken, toilet, bad, skorsten, fuldisolering, indlagt vand og autoriseret spildevandsafledning. Flere var opført på piller og med et højere islæt af selvbyg og billigere typesommerhuse. Endelig blev det i disse sommerhusbyer langt mere udbredt, at der først opførtes et skur eller en garage før, der efter flere år opførtes et egentligt sommerhus på de enkelte grunde. ${ }^{44}$

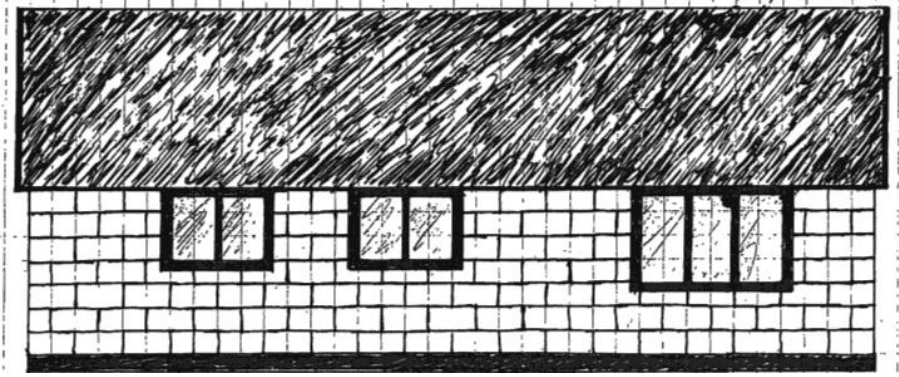

Med lidt teknisk snilde kunne mange også selv opføre et gasbetonhussommerhus som dette fra sommerhusbyen Gershøj fra 1964 (Frederikssund kommune digitale byggesager, https://www.weblager.dk/).

\section{Forsyning}

I lighed med de udvidede del af sommerhusbybæltet ved Kattegatkysten og sommerhusbyerne i kysbæltet ved Roskilde Fjords nord- og østside, forsynedes sommerhusbyerne i Hornsherred nærmest fra starten med elektricitet fra NESA. Da sommerhusbyerne på halvøen i modsætning til de øvrige regionale sommerhusbyområder i hovedstadsmetropolen lå mere isoleret, modtog kun det mindretal, der var beliggende nærmere en landsby herfra trykvand fra enten et kommunalt eller privat andelsejet vandværk. I hovedparten af Hornsherreds sommerhusbyerne måtte de grundejerforeninger, der også her oprettedes som følge af de pålagte udstykningsdeklarationer, blandt mange opgaver derfor etablere et vandværk og forestå udlægning af vandledningsnettet.

Som følge af den senere sommerhusudstykning- og bebyggelse i Hornsherreds sommerhusbyer blev kun en mindre del af disse, svarende til 18,2 procent af antallet sommerhuse, kloakeret i efterkrigstiden. I hovedparten af de øvrige sommerhusbyer blev spildevandsafledningen baseret på sivebrønde eller septiktanke, men i modsætning til forholdene ved Roskilde Fjords nord- og østside blev en større andel, 5 procent, af sommerhusene på halvøen ikke tilsluttet sådanne spildevandsafledningssystemer. ${ }^{45}$

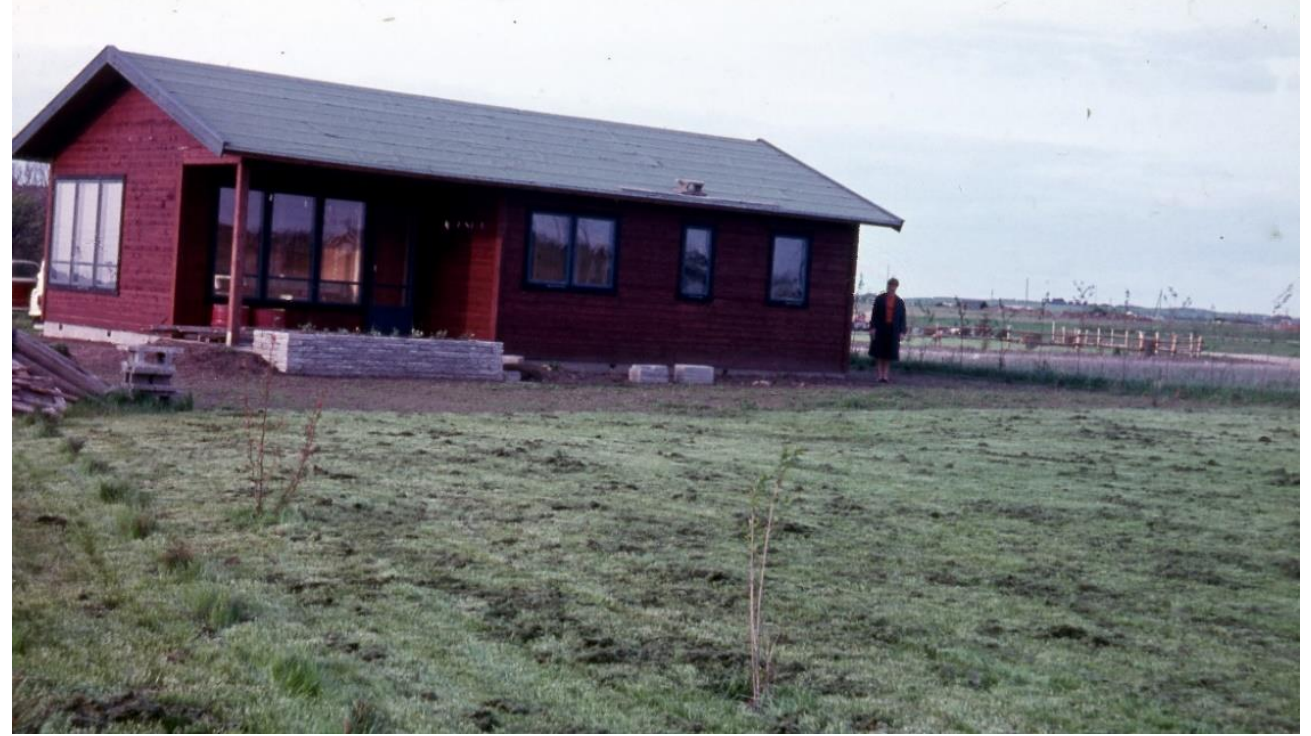

Et karakteristiske Hornsherred-sommerhus en gang i midten af 60'erne i sommerhusbyen Over Draby Strand (Stillet til rådighed af Henrik Clausen, Frederiksberg Stadsarkiv) 


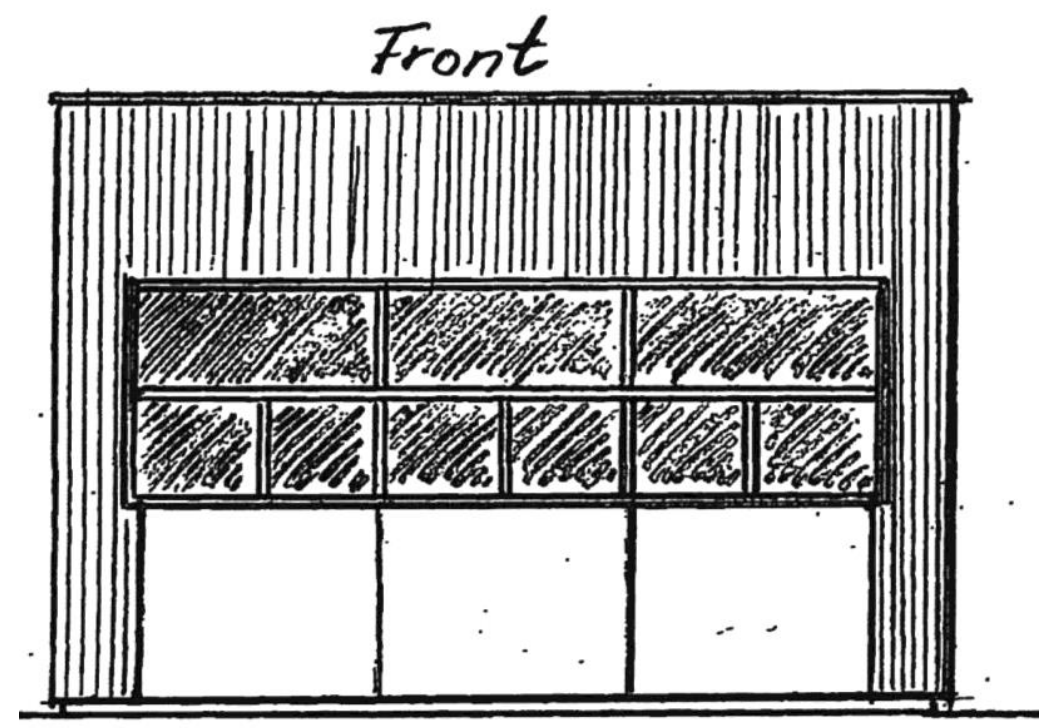

I mangel af større bymæssige bebyggelser og betydelige afstande til nærmeste landsby med brugs eller købmandshandel, blev dagligvareforretninger og andre byerhverv særlig udbredt i Hornsherreds sommerhusbyer. Beskedne var forholdene dog i sommerhusbyen Tørslev Hage med denne lille salgskiosk fra 1965 (Frederikssund Kommune, digitale byggesager, https://www.weblager.dk/)

\section{Erhverv}

Som konsekvens Hornsherreds placering i udkanten af hovedstadsmetropolens åbne land, lave urbaniseringsgrad og dermed, på nær landevejsbyen Skibby på halvøens indre del, mangel på større bydannelser med flere og mere differentierede byerhverv, kom de mellemstore, større og store sommerhusbydannelser her til at dannede et bymæssigt erhvervsgrundlag i et videre omfang end flere andre steder i metropolens sommerhusbyer. Mens dagligvareindkøb i 13 af Hornsherreds mindre og større sommerhusbyer, med knapt en fjerdel af halvøens sommerhuse, var henvist til de nærmeste landsbyer, eller dem de var vokset sammen med, havde syv af halvøens sommerhusbyer, med mere end trefjerdele af sommerhusene, derimod en sådan størrelse eller en så isoleret beliggenhed, at der her var grundlag for selvstændig dagligvarehandel.

I form af en enkelt købmandshandel i den mellemstore sommerhusby Tørslev Hage og egentlige supermarkeder i den ene af den store sommerhusbyer, Over Dråby Strand, og i to af de større, Kyndeløse Sydmark og Vellerup Sommerby. I den mellemstore sommerhusby Lindenborg og den større Dalby Huse i form af henholdsvis fire dagligvareforretninger og et supermarked og en dagligvarebutik.

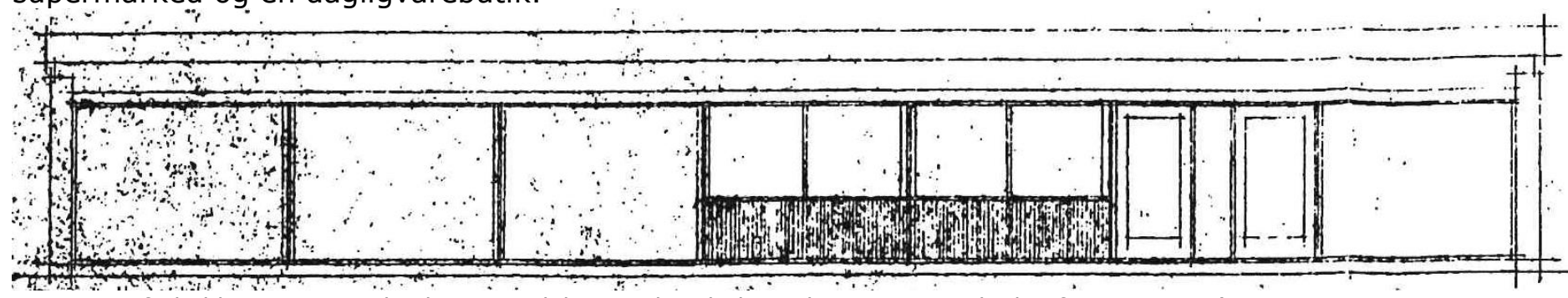

Større var forholdene i sommerhusbyen Kyndeløse Sydmark, hvor dette supermarked opførtes i 1966 (Lejre Kommune, digitale byggesager, https://www.weblager.dk/)

Mens sommerhusbyerne med et supermarked og flere butikker med dagligvare i gennem efterkrigstiden havde et kundegrundlag svarende til mellem 500 og 1.000 sommerhuse, blev der med 3.232 sommerhuse, svarende til 36 procent af Hornsherreds sommerhuse, i Kulhuse grundlag for en betydelig erhvervsudvikling. En erhvervsgrundlag, der tillige understøttedes af sommerhusbyens campingplads, andre former for landliggerbosætninger, feriekolonier, mindre 
helårsbebyggelse, fjerne beliggenhed og et adskillende stort miltært øvelsesterræn på det nordligste Hornsherred.

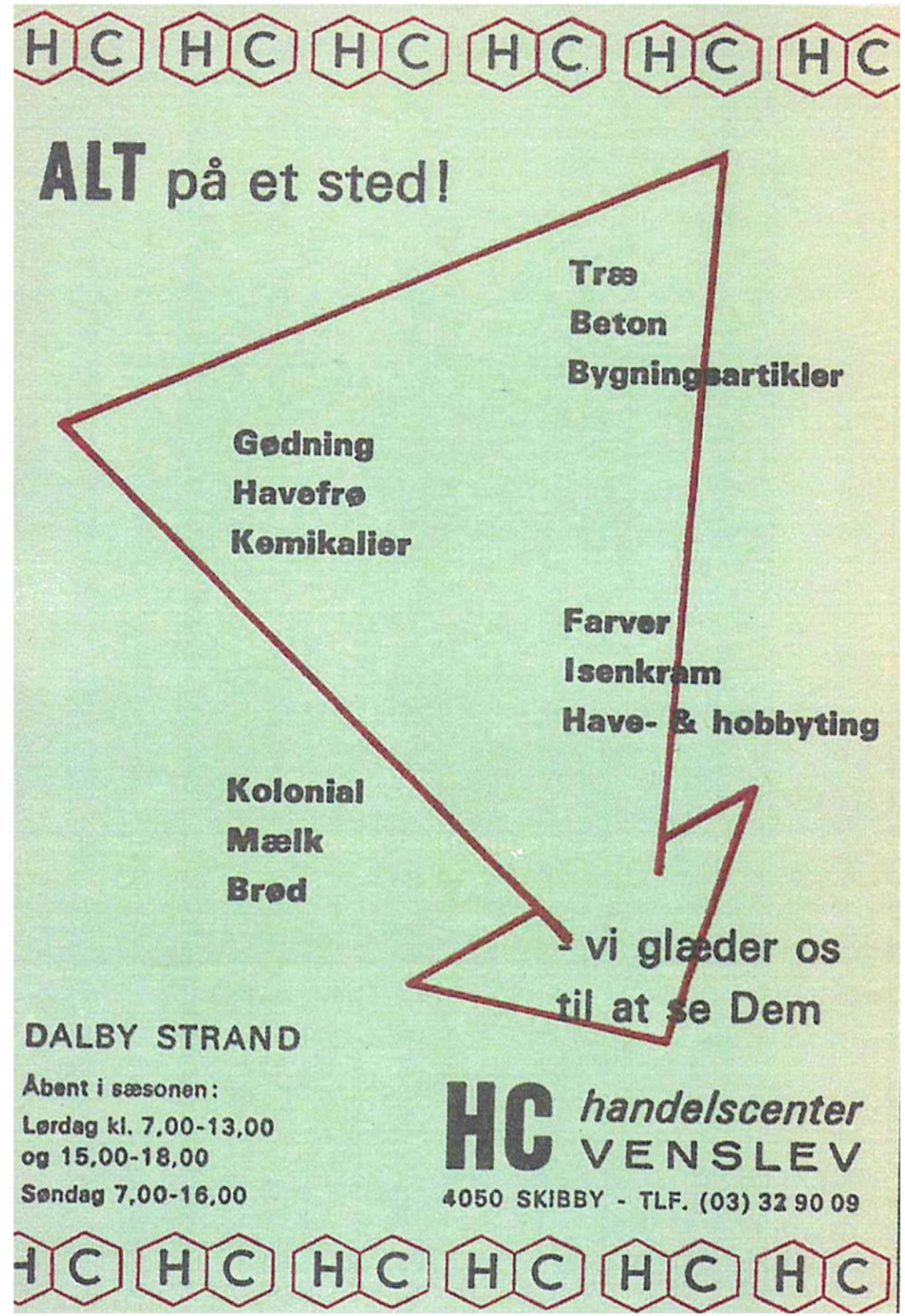

Bymæssige erhverv blev særlig udbredt i de store sommerhusbyer p̊ Hornsherreds Isefjords kyst. Her en reklame fra 1964 for HC Handelscenters filial i sommerhusbyen Dalby Huse (www.bramsmaesvig-grundejer.dk)

Inden for detailhandel etableredes således i Kulhuse i den første efterkrigstid: Fire købmandshandler, tre supermarkeder, ni andre dagligvareforretninger samt tre kiosker. I 1970 i vid udstrækning lokaliseret til et selvgroet centerområde, Huldet, ved sammenløbet af den gennemgående landevej, Kulhusevej, og Barakvej, Krakasvej og Frejasvej med stort supermarked, HG-Konsum, isenkramforretning, trælasthandel og mindre detailhandelsforretninger: Hjemmebageri, slagterforretning, købmandshandel og grønthandler. 
Og ellers fordelt med flere forretninger på sideveje til den gennemgående landevej og et mindre antal spredt i sommerhusbyen. Som følge af en koncentration af detailhandelen til HGkonsum, der senere blev overtaget af den lokale brugs, den forstærkede privatbilisme, køleskab i sommerhusene samt indkøb i lavprisvarehuse i Frederikssund og Jægerspris reduceredes antallet efterhånden til fire virksomheder: En storbrugs, en blomsterforretning, en restaurant og et pizzeria.

Foruden den betydelige dagligvarehandel etableredes i Kulhuse ligesom i den større sommerhusby Dalby Huse isenkram og byggemarked med bygge- og haveartikler med et samlet kundegrundlag på 1.740 sommerhuse pr. sommerhusby. Hornsherreds to store sommerhusbyer Kulhuse og Over Dråby Strand dannede med 1.928 sommerhuse pr. sommerhusby samtidig basis for hvert sit tømmerfirma. Kulhuses tømmerfirma fik desuden en tømmerhandel, der i perioden 1953-1993 producerede typesommerhuset: Jægerspris-huset. En typesommerhusproduktion, der ligesom i Smidstrup, opstod på basis af en mere lokal efterspørgsel, men som ikke vandt større udbredelse hverken i Kattegatkystens sommerhusbybælte eller i Hornsherreds sommerhusbyer.

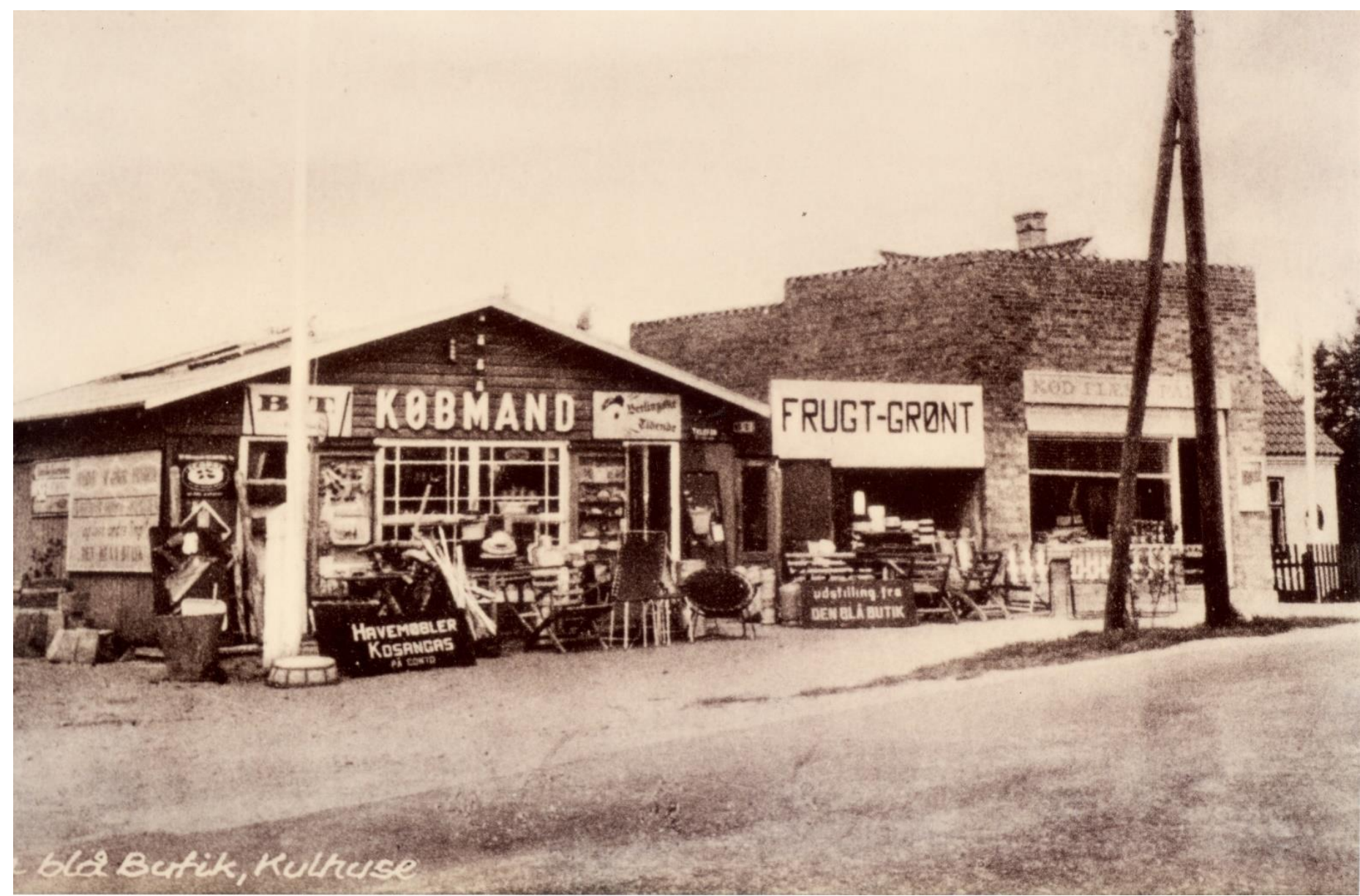

Mest erhvervsudviklet blev Hornsherreds største sommerhusby Kulhuse. Her nogle af de ældre butikker fra 1950. (Frederikssund Lokalhistoriske Arkiver, Jægerspirs Arkiv)

Kulhuse fik i efterkrigsperioden endelig et snedkerfirma og en benzintank samt en række andre erhvervsmæssige funktioner i form af en campingplads, et vandrehjem, pensionater, hotel- og restaurationsvirksomhed, et kursus- og feriecenter, en efterskole, en lejrklub og et større antal ferie- og sommerkolonier. Funktioner, der efterkrigstiden i et vist omfang også etableredes i en række andre af Hornsherreds sommerhusbyer. I form af en campingplads i Kyndeløse Sydmark, hotel- og restaurationsvirksomhed i Ejby og Gershøj strande og i Dalby Huse, efterog specialskoler i Lindenborg og Ejby Strand samt en feriekoloni i Rendebæk. ${ }^{46}$ 


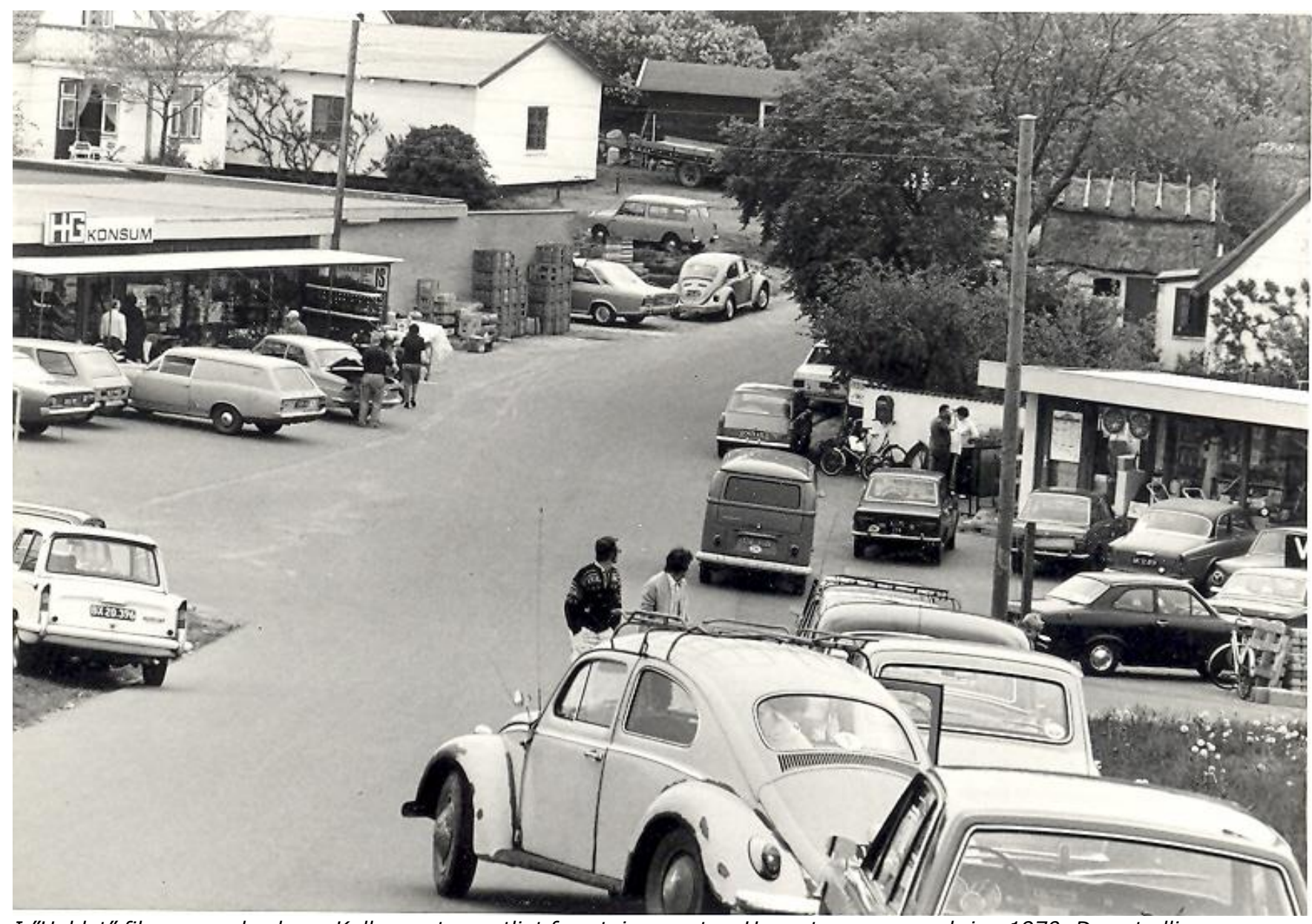

I "Huldet" fik sommerhusbyen Kulhuse et egentligt forretningscenter. Her set en gang omkring 1970. Den stedlige parkerede bilpark omfattede mindre typer af personbiller og pletklarede ældre VW type 1 modeller, som ikke i samme grad var udbredte $i$ sommerhusbybæltet ved Kattegatkysten. (Frederikssund Lokalhistoriske Arkiver, Jægerspirs Arkiv) 


\section{Øvrige sommerhusbyer}

Mens de kystnære sommerhusbyer ved Kattegat og Roskilde Fjords nord- og østside og i Hornsherred opsugede 90 procent af efterkrigstidens sommerhusboom, blev den restende tiendedel fordelt på en række sommerhusbyer i hovedstadsmetropolens øvrige åbne land; jf. Appendix VI.D. Sommerhusbyer, der adskilte sig markant både indbyrdes og i forhold til de kystnære for så vidt lokaliseringsfaktorer og- mønstre, bystørrelse og- struktur, social sammensætning og sommerhusbebyggelsens karakter.

\section{Volume og lokalisering}

Af sommerhusene i hovedstadsmetropolens sommerhusbyer, der i efterkrigstiden udvidedes eller opstod som nye i metropolens øvrige åbne land, blev en større andel, 84 procent, opført i den første efterkrigstid, og fordelte sig gennem hele efterkrigstidsperiode med en mindre halvdel i sommerhusbyer på hovedstadsmetropolens sydlige del ved Køge Bugt og en større halvdel i tilsvarende byer i dens åbne land i det øvrige Nordøstsjælland (tabel III.32). Blandt sidstnævnte opførtes knapt halvdelen i mere koncentrerede sommerhusbyer i Kattegatkystens fjernere bagland: Et 6-12 km langt bælte fra kystens sommerhusbybælte og ned til sydspidsens af det nordlige Nordsjællands store søer: Gurre Sø, Esrum Sø og Arresø. Den $\varnothing$ vrige større halvdel voksede op i en række mere spredtliggende sommerhusbyer i det $\varnothing$ vrige Nordøstsjælland.

I forhold til hovedparten af somerhusbyerne ved Roskilde Fjord nord- og østside og $\mathrm{i}$ Hornsherred påbegyndte udstykningsprocessen i hovedstadsmetropolens øvrige sommerhusbyer tidligere. Knapt halvdelen gennem det 20 . århundredes første halvdel ved Køge Bugt, og de øvrige sommerhusbyer i overvejende grad i løbet af 40 'erne. Følgelig udvidedes de i højere grad i den første efterkrigstidsperiode, og alene sommerhusbyerne i Kattegatkystens fjernere opland blev i videre omfang udbygget i den sidste efterkrigstid.

Tabel III.32. Procentvis fordeling af sommerhuse samt udstyknings- og bebyggelsesperioder, hovedstadsmetropolens $\varnothing$ vrige sommerhusbyer, $1950-1990$.

\begin{tabular}{|l|l|l|l|l|l|}
\hline \multirow{2}{*}{$\begin{array}{l}\text { Delregionale } \\
\text { område }\end{array}$} & Procentandel af antal sommerhuse & Udstykningsperiode & Bebyggelsesperiode \\
\cline { 2 - 5 } $\begin{array}{l}\text { Kattegatkysten } \\
\text { fjernere bagland }\end{array}$ & 23,7 & 28,6 & 24,5 & $(1946)-1969$ & $(1949)-1989$ \\
\hline $\begin{array}{l}\emptyset v \text { vige } \\
\text { Nordøstsjælland }\end{array}$ & 27,1 & 24,9 & 26,7 & $(1946)-1967$ & $1950-1988$ \\
\hline $\begin{array}{l}\text { Hovedstadsmetropo } \\
\text { lens sydlige del }\end{array}$ & 49,2 & 46,5 & 48,8 & $1952-1962$ & $1956-1989$ \\
\hline
\end{tabular}

Kilde: Appendix VI.D.

Mens sammenfaldet af kystnærhed, eksisterende stedlige byerhverv og gode vej- og kollektivtrafikale forbindelser, i lighed med Kattegatkysten, blev afgørende for den regionale placering af de sommerhuse, der i efterkrigstiden opførtes ved Køge Bugt, indgik en række andre faktorer bag lokaliseringen af de andre øvrige sommerhusbyer i hovedstadsmetropolen: I Kattegatkystens fjernere bagland beliggenheder i nærheden af kystens eftertragtede sommerhusbybælte eller direkte ved det nordligste Nordsjællands søer. I det øvrige af Nordøstsjællands sommerhusbyer hovedsagelig med udgangspunkt i tidligere sommerhusenklaver enten ved søer eller i udkanten af Nordforstæderne. ${ }^{47}$

\section{Bystruktur}

Fik Hovedstadsmetropoplen øvrige sommerhusbyer en langt mere spredtliggende karakter i forhold til sommerhusbykoncentrationerne ved Kattegatkysten og Roskilde Fjords nord- og $\emptyset$ stside og i Hornsherred, adskilte de sig tillige for så vidt byernes størrelse, struktur, sociale sammensætning og bebyggelse. 


\section{Bebyggelse}

Mens mere end trefjerdele af hovedstadsmetropolens efterkrigstidssommerhuse opførtes i store og større sommerhusbyer, der alene omfattende knapt 40 procent af samtlige af dens sommerhusbyer, tegnede denne sommerhusbykategori i metropolens $\varnothing$ vrige sommerhusbyer sig alene for godt en tiendedel, som kun rummede godt 40 procent af disses sommerhuse (tabel III.33). Til gengæld blev tæt ved 60 procent af sommerhusene her fordelt på mellemstore og mindre sommerhusbyer, der udgjorde knapt 90 procent af de øvrige sommerhusbyer i hovedstadsmetropolen.

Tabel III.33. Procentvis fordeling efter sommerhusby størrelse, hovedstadsmetropolens øvrige sommerhusbyer,19501990

\begin{tabular}{|l|l|l|}
\hline & $\begin{array}{l}\text { Procentvis fordeling efter antal } \\
\text { huse }\end{array}$ & Antal sommerhusbyer \\
\hline Store somerhusbyer (over 1.000 huse) & 27,4 & 1 \\
\hline Større sommerhusbyer (500-999 huse) & 14,8 & 1 \\
\hline Mellemstore sommerhusbyer (200-499) & 35,6 & 4 \\
\hline Mindre sommerhusbyer (Mindre end 199) & 22,2 & 13 \\
\hline Total & 100 & 19 \\
\hline
\end{tabular}

Kilde: Appendix VI.D.

Lige på nær den store og den større sommerhusby ved Køge Bugt, der udsprang af ældre somerhusbydannelser, og hvor den videre bebyggelse i efterkrigstiden, ligesom i hovedparten af hovedstadsmetropolens sommerhusbyer, dannedes som tidsmæssigt forskudte koncentriske lag ved omfattede systemer af side- og parallelveje fra kystlinjen og ind i det umiddelbare bagland, fik det store antal af metropolens øvrige mellemstore og mindre sommerhusbyer en anden og mindre kompleks bebyggelsesstruktur: I sommerhusbyerne ved stedlige søer ganske vist også i form af tidsmæssigt forskudte lagvise bebyggelser fra søbredderne, men ved mindre vejsystemer og med en langt mindre udbredelse ind i baglandet. I sommerhusbyer $\mathrm{i}$ hovedstadsmetropolens indre åbne land i form af samtidige bebyggelser inden for samme sommerhusbyområde ved vejsystemer af forskellige udbredelse.

Tabel III.34. Procentvis social sammensætning af førstegangssommerhusejere i hovedstadsmetropolens øvrige sommerhusbyer, 1950-1973, og i hovedstadsmetropolen, 1950 og 1970.

\begin{tabular}{|c|c|c|c|c|c|c|}
\hline \multirow[t]{3}{*}{ Stilling } & \multirow{3}{*}{\multicolumn{2}{|c|}{$\begin{array}{l}\text { Sommerhusejere, } \\
1950-1973\end{array}$}} & \multicolumn{4}{|c|}{$\begin{array}{l}\text { Hovedstadsmetropolens erhvervsbeskæftigede } \\
\text { befolkning }\end{array}$} \\
\hline & & & \multicolumn{2}{|c|}{1950} & \multicolumn{2}{|c|}{1970} \\
\hline & & & Hovedstaden & Forstæder & Hovedstaden & Forstæder \\
\hline Større selvstændige & 5,0 & & & & & \\
\hline Mindre selvstændige & 20,3 & & & & & \\
\hline Selvstændige, total & & 25,3 & 11,7 & 17,4 & 7,1 & 9,5 \\
\hline Ledende funktionærer & 3,6 & & & & & \\
\hline Akademisk uddannede funktionærer & 10,8 & & & & & \\
\hline Højere funktionærer, i alt & 14,4 & & & & & \\
\hline Øvrige funktionærer & 45,8 & & & & & \\
\hline Funktionærer, total & & 60,2 & 33,0 & 24,2 & 42,6 & 44,6 \\
\hline Faglærte arbejdere & 12,1 & & & & & \\
\hline Ufaglærte arbejdere & 2,4 & & & & & \\
\hline Arbejdere, total & & 14,5 & 53,3 & 58,4 & 50,0 & 44,1 \\
\hline Total & 100 & 100 & 100 & 100 & 100 & 100 \\
\hline
\end{tabular}

Kilde: Henvisninger under Appendix VI.D. Bro: Hovedstadsmetropolen- den danske byregion 2020, s. 547-548.

I modsætning til sommerhusbyerne ved Kattegatkysten og Roskilde Fjords nord- og østside og i Hornsherred, der i efterkrigstiden bevarede deres karakter sommerhusbyer, blev 44 procent af sommerhusene hovedstadsmetropolens øvrige sommerhusbyerne i løbet af perioden reelt opsuget i metropolens bymæssige helårsbebyggelse. Ved et stadig mere omfattende byggeri af enfamiliehuse overgik den overvejende del af sommerhusbyerne ved søerne i Kattegatkystens fjernere bagland, svarende til 13,4 procent af sommerhuse i hovedstadsmetropolens øvrige sommerhusbyer, de facto til at blive en del af metropolens pendlersatellitby i det nordligste Nordsjælland, mens knapt en tredjedel af sommerhusene dels ved Køge Bugts østlige del, dels 
i de tre sommerhusbyer i udkanten af de nordlige forstæder blev en del af hovedstadsmetropolens forstæder. ${ }^{48}$

Tabel III.35. Procentvis fordeling af bopælsområde og boligform for førstegangssommerhusejere i hovedstadsmetropolens øvrige sommerhusbyer, 1950-1973, og i hovedstadsmetropolen, 1950 og 1970.

\begin{tabular}{|l|l|l|l|}
\hline & Sommerhusejere & \multicolumn{2}{l|}{ Hele hovedstadsmetropolens befolkning } \\
\hline Bopæl i: & $1950-1973$ & 1950 & 1970 \\
\hline Hovedstaden & 56,3 & 61,9 & 41,8 \\
\hline Nordegnen & 18,6 & 12,2 & 13,5 \\
\hline Nordvestegnen & 12,8 & 3,8 & 8,5 \\
\hline Vestegnen & 10,1 & 7,0 & 15,4 \\
\hline Andet & 2,2 & 15,1 & 20,8 \\
\hline Total & 100 & 100 & 100 \\
\hline Etagebolig & 54,7 & 82,3 & 74,7 \\
\hline Enfamiliehuse & 45,3 & 17,7 & 25,3 \\
\hline Total & 100 & 100 & 100 \\
\hline
\end{tabular}

Anm: Fordelingen på etageboliger og enfamiliehuse omfatter alene hovedstaden og forstadsegnene

Kilde: Henvisninger under Appendix VI.D. Statistiske Årbog for København, Frederiksberg m.m., 1952, s. 1, 55, 191-

192 og 198. https://www.kk.dk/sites/default/files/migrated/sc/1972-aarbog.pdf

https://www.kk.dk/sites/default/files/migrated/sc/1975-aarbog.pdf

\section{Social sammensætning}

Selv om arbejderklassen opnåede en noget mindre andel af førstegangsgangssommerhusejerne i hovedstadsmetropolens øvrige sommerhusbyer end i sammes samlede mængde af sommerhusbyer, blev andelen sommerhusejende øvrige funktionærer og mindre selvstændige højere her end i metropolens sommerhusbyer som helhed, hvor ejerguppen af større selvstændige og højere funktionærer tegnede sig for en noget større andel (tabel III.34). En konsekvens af at hovedstadsmetropolens øvrige sommerhusbyer ikke havde samme attraktive beliggenhed ved hovedstadsmetropolens Kattegat- og fjordkyster, og grundpriserne her følgelig blev relativt mindre.

Også i hovedstadsmetropolens øvrige sommerhusbyer satte den sociale sammensætning af førstegangsommerhusejer sig i gennem for så vidt disses fordeling på regionale bopælsområder og umiddelbare boligforhold (tabel III.35). Selv om førstegangsommerhusejerne i hovedstadsmetropolens øvrige sommerhusbyer i stort set samme omfang beboede lejligheder i etagebyggeri eller enfamiliehuse som samme ejergruppe i metropolens sommerhusbyer som helhed, havde en større andel bopæl i selve hovedstaden og i de mindre velstående forstæder på Nordvestegnen, og en tilsvarende mindre andel bopæl i de nordlige velhaverforstæder. ${ }^{49}$

Tabel III.36. Parametre for sommerhusstandarden i hovedstadsmetropolens øvrige sommerhusbyer, $1950-1973$.

\begin{tabular}{|c|c|c|c|c|c|}
\hline \multirow[t]{2}{*}{ Opført, i procent: } & Som selvbyg & Af bygmester & Med arkitektbistand & Af byggefirma & Total \\
\hline & 10,7 & 36,8 & 9,3 & 43,2 & 100 \\
\hline \multicolumn{6}{|c|}{ Rumfordeling, i procent: } \\
\hline 1 rum & 2 rum & 3 rum & 4 rum & 5 el. fl. Rum & Total \\
\hline 3,3 & 28,4 & 51,7 & 14,3 & 2,3 & 100 \\
\hline \multirow[t]{2}{*}{ Toilet, i procent: } & Udenfor huset & I huset & Total & \multirow{2}{*}{\multicolumn{2}{|c|}{$\begin{array}{l}50,8 \text { procent med bad. } \\
2,1 \text { procent uden køkken }\end{array}$}} \\
\hline & 23,9 & 76,1 & 100 & & \\
\hline Areal: & \multicolumn{2}{|c|}{ Mellem $18-132 \mathrm{~m}^{2} . \mathrm{I}$ gennemsnit $49,6 \mathrm{~m}^{2}$} & Udvidelser: & \multicolumn{2}{|c|}{ I gennemsnit $20,2 \mathrm{~m}^{2}$} \\
\hline \multicolumn{3}{|c|}{ Opført, procentfordeling: } & \multicolumn{3}{|c|}{ Forsynet, procentfordeling: } \\
\hline Af træ & Som grundmuret & Total & Med skorsten & Uden skorsten & Total \\
\hline 84,6 & 15,4 & 100 & 61,9 & 38,1 & 100 \\
\hline \multicolumn{2}{|c|}{ Opført på, procentfordeling: } & \multicolumn{2}{|c|}{ Vandforsyning, procentfordeling: } & \multicolumn{2}{|c|}{ Spildevandsafledning, procentfordeling: } \\
\hline Piller & Fundament & Udenfor hus & I hus & Ingen & Sivebrønd m.m. \\
\hline 16,3 & 83,7 & 10,7 & 89,3 & 10,7 & 89,3 \\
\hline
\end{tabular}

Kilde: Henvisninger under Appendix VI.D.

\section{Sommerhusstandard}

I lighed med hovedstadsmetropolens samlede mængde sommerhusbyer satte den sociale sammensætning af førstegangsommerhusejere sig også i gennem i forhold til de kvaliteter, der knyttede sig til metropolens øvrige sommerhusbyer (tabel III.36). Her blev selvbyg og anvendelse af 
håndværkmestre mere almindeligt ved opførelsen af de stedlige sommerhuse, mens benyttelse af arkitektbistand i den forbindelse og typesommerhuse blev langt mindre udbredt. Arealmæssigt blev sommerhusene mindre og omfattede i større omfang huse med 1-3 værelser end i hovedstadsmetropolens sommerhusbyer som helhed. I forhold til disse var sommerhusene i metropolens øvrige sommerhusbyer desuden i langt større omfang uden toilet og bad, og manglede indlagt vand, udledning af spildevand til sivebrønd, septiktank eller offentlig kloak og bad, og rummede flere opført på sokkelsten og uden køkken. Af den mindre andel af typesommerhuse i hovedstadsmetropolens øvrige sommerhusbyer, svarede disses fordeling på de forskellige producenter dog til metropolens sommerhusbyer som helhed (tabel III.37). ${ }^{50}$

Tabel III.37. Procentvis fordeling af ti største og andre producenter af sommertypehuse i hovedstadsmetropolen, 1950-1973.

\begin{tabular}{|l|l|}
\hline Jeppesens Savværk & 19,6 \\
\hline Myresjö Huse & 18,9 \\
\hline Västkust Stugan & 16,2 \\
\hline Skarrids $\varnothing$ Huse & 12,3 \\
\hline Trelleborg Huse & 7,8 \\
\hline Tectum & 5,6 \\
\hline Anneberg Hus & 3,4 \\
\hline Smidstrup Huset & 2,8 \\
\hline Scanda Huse & 2,3 \\
\hline Sadari Huset & 2,2 \\
\hline Andre & 8,9 \\
\hline Total & 100 \\
\hline
\end{tabular}

Kilde: Henvisninger under Appendix VI.D.

\section{Forsyning}

Som i hovedstadsmetropolens samlede mængde sommerhusbyer kom NESA også til at varetage elektricitetsforsyningen til dens øvrige sommerhusbyer. Da disse ofte lå i nærheden af ældre landsbyer eller udsprang af tidligere sommerhusbydannelser, blev ikke mindre end knapt 90 procent af sommerhusene her vandforsynet fra eksisterende private eller kommunale vandværker, mens vandforsyningen til kun en tiendedel måtte tilvejebringes af de lokale vandværker, som disse sommerhusbyers grundejerforeninger måtte etablere.

Da ni tiendedele af hovedstadsmetropolens øvrige sommerhusbyer var mindre eller mellemstore, blev kun 20 procent af disse kloakeret i perioden, hvorved spildevandsafledningen her alene blev baseret på sivebrønde eller septiktanke; dog således at ikke mindre end en tiendel af sommerhusene ikke her tilsluttedes sådanne anlæg. I de store og større sommerhusbyer ved Køge Bugt fuldførtes kloakeringen derimod i fuldt omfang allerede i den første efterkrigstid. ${ }^{51}$

\section{Erhverv}

For den tredjedel af efterkrigstidens sommerhuse i hovedstadsmetropolens øvrige sommerhusbyer, der opførtes i Køge Bugts sydligste sommerhusbybæltet ved bugtens østside, sikredes her behovet for dagligvareindkøb og håndværksmæssige tjenesteydelser af de forretninger og virksomheder, der allerede før midten af det 20 . århundrede var opstået ned langs Køgevejen. Bymæssige erhverv, der blev voldsomt udbygget i takt med, at sommerhusbybæltet i efterkrigstiden gradvist omdannedes til villakvarterer i det forstadsbælte, der opstod langs Køge Bugts nordligste del.

I den eneste store sommerhusby blandt hovedstadsmetrolens øvrige sommerhusbyer, Strøby Strand, havde Køge Bugts særlige attraktioner og sommerhusbydannelsen op gennem den første halvdel af det 20. århundrede skabt grundlag for en købmandshandel, filialer af pengeinstitutter, et badehotel og flere pensionater. Med sommerhusbyens meget betydelige udvidelse i efterkrigstiden opstod samtidig her grundlag for yderligere erhverv. I form af to nye købmandsforretninger, en bagerforretning, en slagterforretning, et supermarked, et autoværksted med benzintank, et tømmer- og snedkerfirma, en VVS-virksomhed, en 
vognmandsforretning, et postkontor, to restauranter, et diskotek samt private Stevns Camping med fællesbygninger og kiosk.

Trods den isolerede og spredtliggende karakter blev der som følge af de mindre og mellemstore sommerhusbydannelser blandt hovedstadsmetroplens andre øvrige sommerhusbyer ikke her skabt et tilstrækkeligt grundlag for bymæssige erhverv. Dagligvareindkøb og rekvirering af håndværksmæssige ydelser blev derfor henvist til den stedlige nærmeste større bymæssige bebyggelse: Den nærmeste større sommerhusby, landsby, stationsby, købstad eller forstadsbydel. ${ }^{52}$

\section{På lokalniveau}

Fik hovedstadsmetropolens øvrige sommerhusbyer i efterkrigstiden en på alle måder anden karakter end sommerhusbyer ved Kattegat og Roskilde Fjords nord og østside og i Hornsherred, adskilte de sig samtidig i betydelig grad fra hinanden, og hvilede på forskellige forudsætninger.

\section{Kattegatkystens fjernere bagland}

Af hovedstadsmetropoplens øvrige 19 sommerhusbyer opstod de ti, svarende til knapt en fjerdedel af sommerhusene i disse, i efterkrigstiden i Kattegatkystens fjernere opland. Lige på nær de to mindre sommerhusbyer, Lundebakke og Ørby, der i 60'erne lagde sig i en afstand på omkring $2 \mathrm{~km}$ fra Kattegats sommerhusbybælte, opstod de otte andre ved de tre store søer i Kattegatkysten fjernere bagland i form af (tabel III.38): To mellemstore sommerhusbyer, Langes $\varnothing$ og Nødebo, der med udgangspunkt i de første udstykninger tilbage fra slutningen 40 'erne opstod ved henholdsvis Gurre Søs vestside og Esrums Søs sydvestside. Seks mindre sommmerhusbyer, som udstykkedes i slutningen af 50 'erne og gennem det følgende tiår rundt om Arresø. Disse omfattede sommerhusbyerne: Bækkekrog, Ramløse Søkrog, Ramløse Bakker, Bakkelandet, Lykkesholm og Auderød.

Tabel III.38. Procentvis fordeling af sommerhuse samt udstyknings- og bebyggelsesperioder, Kattegatkysten fjernere bagland, 1950-1990.

\begin{tabular}{|l|l|l|l|l|l|}
\hline \multirow{2}{*}{ Sommerhusbyer } & \multicolumn{2}{|l|}{ Procentandel af antal sommerhuse } & \multirow{2}{*}{ Udstykningsperiode } & \multirow{2}{*}{ Bebyggelsesperiode } \\
\cline { 2 - 4 } & $1950-1973$ & $1974-1990$ & $1950-1990$ & & \\
\hline Langes $\varnothing$ & 21,5 & 17,1 & 20,5 & $(1949)-1962$ & $(1949)-1982$ \\
\hline Nødebo & 18,4 & 30,1 & 20,3 & $(1946)-1965$ & $1952-1989$ \\
\hline Lundebakke & 3,0 & 2,4 & 2,9 & 1965 & $1966-1982$ \\
\hline$\varnothing$ rby & 8,8 & 13,5 & 7,5 & $1960-1967$ & $1960-1986$ \\
\hline Bækkekrog & 7,9 & 5,9 & 7,1 & 1963 & $1963-1985$ \\
\hline Ramløse Søkrog & 15,2 & & 11,2 & $1957-1968$ & $1958-1971$ \\
\hline Ramløse Bakker & 5,1 & 5,0 & 5,0 & $1961-1969$ & $1962-1988$ \\
\hline Bakkelandet & 5,9 & 6,5 & 6,0 & $1961-1962$ & $1963-1986$ \\
\hline Lykkesholm & 10,1 & 17,5 & 11,4 & 1962 & $1964-1988$ \\
\hline Auderød & 4,1 & 2,0 & 3,1 & $1956-1961$ & $1957-1975$ \\
\hline Total & 100 & 100 & 100 & $(1949)-1969$ & $(1949)-1989$ \\
\hline
\end{tabular}

Kilde: Henvisninger under Appendix VI.D.

Som ved hovedstadsmetropolens kyst- og fjordnære sommerhusbyer dannedes de otte sommerhusbyer ved søerne i Kattegatkystens fjernere bagland som tidsforskudte koncentriske bebyggelseslag langs større eller mindre vejsystemer fra de stedlige søbredder og nogle hundrede meter ind i baglandet. Mens de to sommerhusbyer i nærheden af Kattegatkystens sommerhusbybælte, og søbredssommehusbyerne Langs $\varnothing$, Lykkesholm og Auderød op gennem hele efterkrigstiden udbyggedes som så, bebyggedes de øvrige sommerhusbyer ved Arres $\varnothing$ i efterkrigsperioden i stadig større omfang med enfamiliehuse, hvorved disse i højere grad fik karakter af pendlersatellitbyer i hovedstadsmetropolen. Ved Esrum Søs sydvestside voksede sommerhusbyen efterhånden sammen med det bælte af enfamiliehuse, der voksede op omkring kirkesognelandsbyen af samme navn, og som fik samme karakter af pendlersatellitby. 
Tabel III.39. Procentvis social sammensætning af førstegangssommerhusejere i Kattegatkysten fjernere bagland, 1950-1973, og i hovedstadsmetropolen, 1950 og 1970.

\begin{tabular}{|c|c|c|c|c|c|c|}
\hline \multirow[t]{3}{*}{ Stilling } & \multirow{3}{*}{\multicolumn{2}{|c|}{$\begin{array}{l}\text { Sommerhusejere, } \\
1950-1973\end{array}$}} & \multicolumn{4}{|c|}{$\begin{array}{l}\text { Hovedstadsmetropolens erhvervsbeskæftigede } \\
\text { befolkning }\end{array}$} \\
\hline & & & \multicolumn{2}{|c|}{1950} & \multicolumn{2}{|c|}{1970} \\
\hline & & & Hovedstaden & Forstæder & Hovedstaden & Forstæder \\
\hline Større selvstændige & 4,4 & & & & & \\
\hline Mindre selvstændige & 15,9 & & & & & \\
\hline Selvstændige, total & & 20,3 & 11,7 & 17,4 & 7,1 & 9,5 \\
\hline Ledende funktionærer & 4,4 & & & & & \\
\hline Akademisk uddannede funktionærer & 12,3 & & & & & \\
\hline Højere funktionærer, i alt & 16,7 & & & & & \\
\hline$\varnothing$ vrige funktionærer & 51,4 & & & & & \\
\hline Funktionærer, total & & 68,1 & 33,0 & 24,2 & 42,6 & 44,6 \\
\hline Faglærte arbejdere & 9,9 & & & & & \\
\hline Ufaglærte arbejdere & 1,7 & & & & & \\
\hline Arbejdere, total & & 11,6 & 53,3 & 58,4 & 50,0 & 44,1 \\
\hline Total & & 100 & 100 & 100 & 100 & 100 \\
\hline
\end{tabular}

Kilde: Henvisninger under Appendix VI.D. Bro: Hovedstadsmetropolen- den danske byregion 2020, s. 547-548.

I forhold til hovedstadsmetropolens øvrige sommerhusbyer kom laget af større selvstændige, højere og øvrige funktionærer i den første efterkrigstid til at indgå med en større andel blandt førstegangsommerhusejerne i Kattegatkystens fjernere bagland, mens arbejderklassen opnåede en tilsvarende mindre andel af samme (tabel III.39). En sammensætning, der var udtryk for, at sommerhusbyerne ved egnens store søer var mere attraktive, og dermed havde højere grudværdier end sommerhusbyerne i det øvrige Nordøstsjælland. Et socialt aspekt, der bevirkede, at ejergruppen i højere grad havde bopæl i nordlige velhaverforstæder end i hovedstaden og de øvrige forstadsegne, og samtidig satte sig igennem ved den karakter, som sommerhusene havde.

Sommerhuse her var således arealmæssigt større, omfattede relativt flere med 4 eller flere værelser og i højere grad rejst med arkitektbistand og som dyrere typesommerhuse end i hovedstadsmetropolens øvrige sommerhusbyer (III.40). Langt flere var desuden fuldisolerede, udrustet med toilet og bad i huset, havde skorsten og indlagt vand, og var tilsluttet spildevandsanlæg og opført på et støbt fundament. ${ }^{53}$

Tabel III.40. Parametre for sommerhusstandarden i Kattegatkysten fjernere bagland, 1950-1973.

\begin{tabular}{|c|c|c|c|c|c|}
\hline \multirow[t]{2}{*}{ Opført, i procent: } & Som selvbyg & Af bygmester & Med arkitektbistand & Af byggefirma & Total \\
\hline & 6,3 & 29,3 & 10,6 & 53,8 & 100 \\
\hline \multicolumn{6}{|c|}{ Rumfordeling, i procent: } \\
\hline 1 rum & 2 rum & 3 rum & 4 rum & 5 el. fl. Rum & Total \\
\hline 0,5 & 23,1 & 55,3 & 19,1 & 2,0 & 100 \\
\hline \multirow[t]{2}{*}{ Toilet, i procent: } & Udenfor huset & I huset & Total & \multirow{2}{*}{\multicolumn{2}{|c|}{$\begin{array}{l}\text { 61,3 procent med bad. } \\
0,1 \text { procent uden køkken }\end{array}$}} \\
\hline & 12,9 & 87,1 & 100 & & \\
\hline Areal: & \multicolumn{2}{|c|}{ Mellem $18-117 \mathrm{~m}^{2}$.I gennemsnit $56,1 \mathrm{~m}^{2}$} & Udvidelser: & \multicolumn{2}{|c|}{ I gennemsnit $16,3 \mathrm{~m}^{2}$} \\
\hline \multicolumn{3}{|c|}{ Opført, procentfordeling: } & \multicolumn{3}{|c|}{ Forsynet, procentfordeling: } \\
\hline Af træ & Som grundmuret & Total & \multirow{2}{*}{ Med skorsten } & Uden skorsten & Total \\
\hline 82,8 & 17,2 & 100 & & 29,1 & 100 \\
\hline \multicolumn{2}{|c|}{ Opført på, procentfordeling: } & \multicolumn{2}{|c|}{ Vandforsyning, procentfordeling: } & \multicolumn{2}{|c|}{ Spildevandsafledning, procentfordeling: } \\
\hline Piller & Fundament & Udenfor hus & I hus & Ingen & Sivebrønd m.m. \\
\hline 5,2 & 94,8 & 4,1 & 95,9 & 4,1 & 95,9 \\
\hline
\end{tabular}

Kilde: Henvisninger under Appendix VI.D.

\section{Øvrige Nordøstsjælland}

Syv af hovedstadsmetropolens 19 øvrige sommerhusbyer, svarende til godt en fjerdele af disses sommerhuse, opstod i efterkrigstiden som to mellemstore, Burre Sø og Ubberød, og fem mindre sommerhusbyer (tabel IIII.41): Slangerup og Farum overdrev, Ravnsnæs, Østrup Holme og Katrinebjerg Hovmark. Fem af disse beliggende i den sydlige del af Nordsjælland: To i det åbne land, Slangerup Overdrev og Burre $S \varnothing$, og tre tæet ved hovedstadsmetropolens nordforstæder: Farum Overdrev, Ravnsnæs og Ubberød. De to øvrige, Østrup Holme og Katrinebjerg Hovmark, isoleret i det vidtstrakte åbne land henholdsvis sydøst og nord for 
kirkesognelandsbyerne Gundsømagle, sydøst for Jyllinge, og Sengeløse, nord for forstaden Høje Tåstrup i Vestegnens forstadsbånd.

Tabel III.41. Procentvis fordeling af sommerhuse samt udstyknings- og bebyggelsesperioder i øvrige Nordøstsjælland, $1950-1990$.

\begin{tabular}{|l|l|l|l|l|l|}
\hline \multirow{2}{*}{ Sommerhusbyer } & \multicolumn{2}{|l|}{ Procentandel af antal sommerhuse } & Udstykningsperiode & \multirow{2}{*}{ Bebyggelsesperiode } \\
\cline { 2 - 4 } & $1950-1973$ & $1974-1990$ & $1950-1990$ & & \\
\hline Slangerup Overdrev & 4,1 & & 3,5 & $1958-1962$ & $1958-1971$ \\
\hline Bure Sø & 27,6 & 49,4 & 31,0 & $(1949)-1967$ & $1950-1988$ \\
\hline Farum Overdrev & 12,7 & 25,3 & 14,4 & $(1946)-1965$ & $1951-1989$ \\
\hline Ravnsnæs & 12,3 & & 10,5 & $(1936-1947)$ & $1950-1954$ \\
\hline Ubberød & 30,4 & & 26,1 & 1950 & $1950-1969$ \\
\hline$\varnothing$ strup Holme & 8,9 & 23,0 & 11,2 & $1961-1964$ & $1963-1988$ \\
\hline Katrinebjerg Hovmark & 4,0 & 2,3 & 3,3 & $1964-1965$ & $1966-1986$ \\
\hline Total & 100 & 100 & 100 & $(1936)-1967$ & $1950-1989$ \\
\hline
\end{tabular}

Kilde: Henvisninger under Appendix VI.D.

Mens sommerhusbyerne Burre Sø og Ravnsnæs opstod på grundlag af tidlige førstegangsudstykninger tilbage fra 30 'erne og slutningen af 40 'erne ved Burre- og Sjælsøer, og dannedes på samme måde og med stort samme udbredelse som i

søbredssommerhusbyerne i Kattegatkystens fjerene bagland, opstod sommerhusbyerne Farum Overdrev og Ubberød, på basis de første udstykninger fra omkring 1950, ved skovområderne umiddelbart henholdsvis nord og syd for nordforstæder Farum og Hørsholm. Mens sommerhusbyen Katrinebjerg Hovmark opstod ved et mindre skov- og søområde, må værdien af det åbne og fri bondeland, og tilgængelige billigere byggegrund have været lokaliseringsfaktoren bag dannelsen af sommerhusbyerne Slangerups Overdrev og Østrup Holme.

Forblev sidstnævnte to sommerhusbyer og tillige sommerhusbyen Bure Sø i rækken af efterkrigstidens øvrige sommerhusbyer i hovedstadsmetropolen, blev eksisterede sommerhuse i sommerhusbyerne Farum Overdrev, Ravnsnæs og Ubberød i et vidt omfang i perioden enten udbygget i et sådan omfang, at de kom til at svare til et helårsenfamiliehus, eller erstattet af et sådant, at de tre sommerhusbyer de facto blev en del af nordforstæderne Farum og Hørsholm. En proces, der i ubemærkethed dog første blev formaliseret i 1982 og i 1999 for så vidt sommerhusbyerne Ravnsnæs og Ubberød, men som i Farum blev politiseret, da den siddende opmærksomhedssøgende Venstre-borgmester Peter Brixtofte bevidst fors $\varnothing$ gte at undergrave sommerhusloven ved i udstrakt grad at give tilladelse til helårsbeboelse $\mathrm{i}$ sommerhusbyen Farum Ovedrev, indtil han med en lokalplan i år 2000 fik givet den helsårsstatus.

Tabel III.42. Procentvis social sammensætning af førstegangssommerhusejere i øvrige Nordøstsjælland, 1950-1973, og i hovedstadsmetropolen, 1950 og 1970.

\begin{tabular}{|c|c|c|c|c|c|c|}
\hline \multirow[t]{3}{*}{ Stilling } & \multirow{3}{*}{\multicolumn{2}{|c|}{$\begin{array}{l}\text { Sommerhusejere, } \\
1950-1973\end{array}$}} & \multicolumn{4}{|c|}{$\begin{array}{l}\text { Hovedstadsmetropolens erhvervsbeskæftigede } \\
\text { befolkning }\end{array}$} \\
\hline & & & \multicolumn{2}{|c|}{1950} & \multicolumn{2}{|c|}{1970} \\
\hline & & & Hovedstaden & Forstæder & Hovedstaden & Forstæder \\
\hline Større selvstændige & 2,9 & & & & & \\
\hline Mindre selvstændige & 20,4 & & & & & \\
\hline Selvstændige, total & & 23,3 & 11,7 & 17,4 & 7,1 & 9,5 \\
\hline Ledende funktionærer & 3,5 & & & & & \\
\hline Akademisk uddannede funktionærer & 9,6 & & & & & \\
\hline Højere funktionærer, i alt & 13,1 & & & & & \\
\hline$\varnothing$ vrige funktionærer & 41,4 & & & & & \\
\hline Funktionærer, total & & 54,5 & 33,0 & 24,2 & 42,6 & 44,6 \\
\hline Faglærte arbejdere & 18,8 & & & & & \\
\hline Ufaglærte arbejdere & 3,4 & & & & & \\
\hline Arbejdere, total & & 22,2 & 53,3 & 58,4 & 50,0 & 44,1 \\
\hline Total & & 100 & 100 & 100 & 100 & 100 \\
\hline
\end{tabular}

Kilde: Henvisninger under Appendix VI.D. Bro: Hovedstadsmetropolen- den danske byregion 2020, s. 547-548. 
I forhold til hovedstadsmetropolens øvrige sommerhusbyer fik dem i det øvrige Nordøstsjælland en yderst særegen social sammensætning (tabel III.42). Andelen af førstegangssommerhusejere fra arbejderklassen lagde sig ganske vist her, med over 22 procent, langt over gennemsnit for disse sommerhusbyer og på linje med Hornsherreds sommerhusbyer, men andelen af mindre selvstændige og øvrige funktionærer blev samtidig så stor, at de tre sociale lag med det samlede laveste indkomstniveau udgjorde mere end 84 procent af førstegangssommerhusejerne. En social sammensætning, der tillige kom til udtryk ved, at mere end tre fjerdedele af denne ejergruppe beboede en lejlighed i en etagebebyggelse, og næsten 70 procent havde bopæl i selve hovedstaden.

Tabel III.43. Parametre for sommerhusstandarden i hovedstadsmetropolens i øvrige Nordøstsjælland, 1950-1973.

\begin{tabular}{|c|c|c|c|c|c|}
\hline \multirow[t]{2}{*}{ Opført, i procent: } & Som selvbyg & Af bygmester & Med arkitektbistand & Af byggefirma & Total \\
\hline & 18,2 & 43,3 & 8,0 & 30,5 & 100 \\
\hline \multicolumn{6}{|c|}{ Rumfordeling, i procent: } \\
\hline 1 rum & 2 rum & 3 rum & 4 rum & 5 el. fl. Rum & Total \\
\hline 8,3 & 46,2 & 37,1 & 8,4 & & 100 \\
\hline \multirow[t]{2}{*}{ Toilet, i procent: } & Udenfor huset & I huset & Total & \multirow{2}{*}{\multicolumn{2}{|c|}{$\begin{array}{l}20,2 \text { procent med bad. } \\
4,5 \text { procent uden køkken }\end{array}$}} \\
\hline & 54,1 & 45,9 & 100 & & \\
\hline Areal: & \multicolumn{2}{|c|}{ Mellem $10-90 \mathrm{~m}^{2} . \mathrm{I}$ gennemsnit $37,3 \mathrm{~m}^{2}$} & Udvidelser: & \multicolumn{2}{|c|}{ I gennemsnit $27,9 \mathrm{~m}^{2}$} \\
\hline \multicolumn{3}{|c|}{ Opført, procentfordeling: } & \multicolumn{3}{|c|}{ Forsynet, procentfordeling: } \\
\hline Af træ & Som grundmuret & Total & Med skorsten & Uden skorsten & Total \\
\hline 88,5 & 11,5 & 100 & 44,8 & 55,2 & 100 \\
\hline \multicolumn{2}{|c|}{ Opført på, procentfordeling: } & \multicolumn{2}{|c|}{ Vandforsyning, procentfordeling: } & \multicolumn{2}{|c|}{ Spildevandsafledning, procentfordeling: } \\
\hline Piller & Fundament & Udenfor hus & I hus & Ingen & Sivebrønd m.m. \\
\hline 36,0 & 64,0 & 20,5 & 79,5 & 20,5 & 79,5 \\
\hline
\end{tabular}

Kilde: Henvisninger under Appendix VI.D.

I samtiden må sommerhusbyerne i det øvrige Nordøstsjælland have haft en så meget mindre attraktiv beliggenhed og muligheden for, at disse kunne overgå til inderzone og senere byzone være blevet anset for så begrænsede, at grundpriserne lagde sig på et så relativt lavere niveau, at et socialt brede udsnit af hovedstadsmetropolens befolkning her fik mulighed for at erhverve en sommerhusgrund. Socioøkonomiske og regionsplanmæssige faktorer, der sammen med den tidligere udbygning af disse sommerbyer bevirkede, at de ud fra parametre for sommerhusstandard lagde sig i den absolutte bund blandt hovedstadsmetropolens samlede mængde sommerhusbyer (tabel III. 43).

Mere end 60 procent sommerhuse blev således her opført som selvbyg eller flikket sammen af en lokal håndværksmester. Med et gennemsnitsareal på $37 \mathrm{~m}^{2}$ og over 90 procent med 1-3 værelser blev sommerhusene i det øvrige Nordøstsjælland hovedstadsmetropolens absolut mindste og samtidig dårligst udrustede. Tæt ved fem procent havde ikke køkken og kun 45 og 20 var med toilet og bad i selve sommerhuset. En langt mindre del var desuden fuldisolerede og kunne opnå opvarmning fra de muligheder, som en skorsten gav. Endelig var over en tredjedel af sommerhusene opført på piller og en femtedel uden tilslutning til en sivebrønd eller septiktank på grunden eller offentlig kloak. ${ }^{54}$

Tabel III.44. Procentvis fordeling af sommerhuse samt udstyknings- og bebyggelsesperioder i hovedstadsmetropolens sydlige del, 1950-1990.

\begin{tabular}{|l|l|l|l|l|l|}
\hline \multirow{2}{*}{ Sommerhusbyer } & \multicolumn{2}{|l|}{ Procentandel af antal sommerhuse } & Udstykningsperiode & \multirow{2}{*}{ Bebyggelsesperiode } \\
\cline { 2 - 4 } & $1950-1973$ & $1974-1990$ & $1950-1990$ & & \\
\hline Køge Bugt & 38,5 & 7,8 & 33,7 & Før 1950, se Del II & $1950-1981$ \\
\hline Strøby Strand & 61,5 & 92,2 & 66,3 & $1952-1962$ & $1956-1989$ \\
\hline Total & 100 & 100 & 100 & $1952-1962$ & $1950-1989$ \\
\hline
\end{tabular}

Kilde: Henvisninger under Appendix VI.D.

\section{Hovedstadsmetropolens sydlige del}

Tæt ved halvdelen efterkrigstidssommerhusene i hovedstadsmetropolens øvrige sommerhusbyer opførtes ved den østlige og sydlige del af Køge Bugt i metropolens sydlige del. Knapt 40 procent i Køge Bugts sydligste sommerhusbybælte, der var vokset frem i mellemkrigstiden og 40 'erne, og de resterede godt 60 procent i sommerhusbyen Strøby 
Strand, som var opstået i samme periode (tabel III.44). Ved Køge Bugt østlige del opførtes sommerhusene på ubebyggede allerede udstykkede parceller, men blev ligesom de ældre sommerhuse snart enten udvidet på en sådan måde, at de fik karakter af helårsenfamiliehuse, eller helt erstattet af sådanne.

Mens sommerhusbybæltet ved Køge Bugts østside, som tidligere anført, blev opsuget i det forstadsbælte, som i efterkrigstiden dannedes i denne del af hovedstadsmetropolen, bevarede Strøby Strand i nogen grad sin karakter af sommerhusby. I lighed med sommerhusbyerne i Kattegatkystens sommerhusbybælte udvidedes Strøby Strand i den første efterkrigstid som en tidsmæssigt forskudt koncentrisk lagvis bebyggelse bag den ældre langstrakte bebyggelse langs Køge Bugts sydside. I den vestlige del ved et større system af side- og parallelveje til gennemgående kystvej og i den østlige del i et smalt bebyggelsesbælte ved side-og parallelveje til samme.

Som en af hovedstadsmetropolens store sommerhusbyer fik Strøby Strand et sådant omfang, at der her, som nævnt, opstod en række byerhverv. Med sommerhusbyens nære beliggenhed i forhold til Køge Bugt forstadsbælte og dermed hovedstadsmetropolens centrale dele, bebyggedes Strøby Strand fra 70 'erne og i de følgende årtier med enfamiliehuse i et sådan omfang, at sommerhusbyen i højere grad udviklede sig til en pendlersatellitby. En forvandlingsproces, der i 2018 mundede ud i, at den vestlige del af sommerhusbyen opgraderes til helårsstatus, mens den østlige del af Strøby Strand foreløbig forblev en sommerhusbydel.

Tabel III.45. Procentvis social sammensætning af førstegangssommerhusejere i sommerhusbyen Strøby Strand, 1950-1973, og i hovedstadsmetropolen, 1950 og 1970.

\begin{tabular}{|c|c|c|c|c|c|c|}
\hline \multirow[t]{3}{*}{ Stilling } & \multirow{3}{*}{\multicolumn{2}{|c|}{$\begin{array}{l}\text { Sommerhusejere, } \\
1950-1973\end{array}$}} & \multicolumn{4}{|c|}{$\begin{array}{l}\text { Hovedstadsmetropolens erhvervsbeskæftigede } \\
\text { befolkning }\end{array}$} \\
\hline & & & \multicolumn{2}{|c|}{1950} & \multicolumn{2}{|c|}{1970} \\
\hline & & & Hovedstaden & Forstæder & Hovedstaden & Forstæder \\
\hline Større selvstændige & 14,5 & & & & & \\
\hline Mindre selvstændige & 7,4 & & & & & \\
\hline Selvstændige, total & & 21,9 & 11,7 & 17,4 & 7,1 & 9,5 \\
\hline Ledende funktionærer & 6,8 & & & & & \\
\hline Akademisk uddannede funktionærer & 14,7 & & & & & \\
\hline Højere funktionærer, i alt & 21,5 & & & & & \\
\hline$\varnothing$ vrige funktionærer & 40,1 & & & & & \\
\hline Funktionærer, total & & 61,6 & 33,0 & 24,2 & 42,6 & 44,6 \\
\hline Faglærte arbejdere & 16,5 & & & & & \\
\hline Ufaglærte arbejdere & & & & & & \\
\hline Arbejdere, total & & 16,5 & 53,3 & 58,4 & 50,0 & 44,1 \\
\hline Total & & 100 & 100 & 100 & 100 & 100 \\
\hline
\end{tabular}

Kilde: Henvisninger under Appendix VI.D. Bro: Hovedstadsmetropolen- den danske byregion 2020, s. 547-548.

Fik Strøby Strand med sin dannelse, sit erhvervsliv, sin campingplads og øvrige landliggerbosætning og sit tilknyttede byerhvervsliv en karakter, der havde betydelige paralleller til de store sommerhusbyer i Kattegatkystens sommerhusbybælte, gjaldt det i nogen grad tillige sammensætningen af førstegangssommerhusejere i denne sommerhusby (tabel III.45). Selv om arbejderklassen her indgik med en noget større andel blandt førstegangssommerhusejerne end ved sommerhusbybæltet ved Kattegat, opnåede højindkomstlaget af større selvstændige og højere funktionærer en andel af denne ejegruppe, der kom i nærheden af Nordsjællandskystens, mens det sommerhusejende lag af arbejdere, øvige funktionærer og mindre selvstændige kom til at udgøre en tilsvarende mindre del.

En social sammensætning, der dels var en funktion af de særlige attraktioner, der knyttede sig til Køge Bugts sydlige kyststrækning, og her bragte grundværdierne op på et relativt højt niveau, dels bevirkede, at et flertal af Strøby Strands førstegangssommerhusejere beboede et enfamiliehus, og i mindre grad havde bopæl i selve hovedstaden. At Vestegnen i højere grad 
udgjorde et bopælsområde for denne ejergruppe, var betinget af den kortere afstand til denne del af hovedstadsmetropolens forstæder.

Tabel III.46. Parametre for sommerhusstandarden i hovedstadsmetropolens sydlige del, 1950-1973.

\begin{tabular}{|c|c|c|c|c|c|}
\hline \multirow[t]{2}{*}{ Opført, i procent: } & Som selvbyg & Af bygmester & Med arkitektbistand & Af byggefirma & Total \\
\hline & 13,1 & 24,6 & 8,2 & 54,1 & 100 \\
\hline \multicolumn{6}{|c|}{ Rumfordeling, i procent: } \\
\hline \multirow[t]{2}{*}{1 rum } & 2 rum & 3 rum & 4 rum & 5 el. fl. Rum & Total \\
\hline & 6,3 & 68,2 & 19,6 & 4,5 & 100 \\
\hline \multirow[t]{2}{*}{ Toilet, i procent: } & Udenfor huset & I huset & Total & \multirow{2}{*}{\multicolumn{2}{|c|}{$\begin{array}{l}70,8 \text { procent med bad. } \\
0,2 \text { procent uden køkken }\end{array}$}} \\
\hline & 6,2 & 93,8 & 100 & & \\
\hline Areal: & \multicolumn{2}{|c|}{ Mellem $36-132 \mathrm{~m}^{2}$.I gennemsnit $60,9 \mathrm{~m}^{2}$} & Udvidelser: & \multicolumn{2}{|c|}{ I gennemsnit $19,9 \mathrm{~m}^{2}$} \\
\hline \multicolumn{3}{|c|}{ Opført, procentfordeling: } & \multicolumn{3}{|c|}{ Forsynet, procentfordeling: } \\
\hline Af træ & Som grundmuret & Total & Med skorsten & Uden skorsten & Total \\
\hline 82,3 & 17,7 & 100 & 73,7 & 26,3 & 100 \\
\hline \multicolumn{2}{|c|}{ Opført på, procentfordeling: } & \multicolumn{2}{|c|}{ Vandforsyning, procentfordeling: } & \multicolumn{2}{|c|}{ Spildevandsafledning, procentfordeling: } \\
\hline Piller & Fundament & Udenfor hus & I hus & Ingen & Sivebrønd m.m. \\
\hline 4,4 & 95,6 & 3,1 & 96,9 & 3,1 & 96,9 \\
\hline
\end{tabular}

Kilde: Henvisninger under Appendix VI.D. .

Som i andre af hovedstadsmetropolens sommerhusbyer satte den sociale sammensætning af førstegangssommerhusejernes sig også igennem i forhold til karakteren sommerhusbebyggelsen ved Strøby Strand (tabel III.46). For alle parametre for sommerhusstandarden opnåede sommerhusbebyggelsen ved Strøby Strand da også en kvalitet, størrelse og udrustning, der lå over sommerhusene både i hovedstadsmetropolen som helhed og metropolens øvrige sommerhusbyer, og kom på niveau med Kattegatkystens sommerhusbybælte. Dog således at typesommerhus og anvendelse af byggehåndværksmestre til opførelsen af sommerhusene udgjorde en større andel ved Strøby Strand, der heller ikke kunne opvise samme volumen af sommerhuse med 4 eller flere værelser som på den nordsjællandske kyst. Til gengæld blev andelen af sommerhuse med 3 værelser, 68 procent, meget betydelige ved Strøby Strand, mens omfanget af små hus med 1-2 værelser her blev begrænset. 55 


\section{Regionsudfordringen}

Med den første efterkrigstids meget store sommerhusbydannelser fulgte en større buket af udfordringer for både lokalsamfundene og af regional karakter. Særlig de regionale forstærkedes, og blev kritiske i forhold til velfærdsstatens vækstforudsætninger og kultur- og fritidspolitiske målsætninger. Et sæt af regionsudfordringer, der sammen med hovedstadsmetropolens øvrige blev overladt til dens uforandrede politisk-administrative rammestruktur suppleret med statslige etapevise regionsløsninger.

\section{De byregionale interaktionsudfordringer}

Strøsteparten af periodens sommerhusbyer opstod således ved omfattende gårdslagtninger uden hensyn til landskabets karakter, terræn- og udsigtsforhold og eksisterende beplantning, men med et frit spillerum for størst mulig fortjeneste og arealudnyttelse med mindst mulige omkostninger til administration og byggemodning. Som oftest i form af en række udstykninger

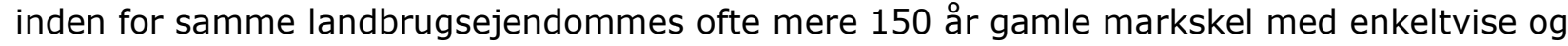
isolerede udlæg af parcelskel og veje uden større sammenhæng med tidligere sommerhusudstykninger og bebyggelser i samme sommerhusbyområde og uden fælles friluftsarealer, parkeringspladser, adgang til lokale udflugtsmål og arealer til eventuelle bygninger med serviceerhverv. En udstykningsform, der gav mange af tidens sommerhusbyer en planløs karakter med uhensigtsmæssige vejforløb, akavede grundformer, utilstrækkeligt drænende grunde, manglende samlede løsninger på vandforsyning, spildevandsafledning og vejsystemer i samme sommerhusby.

Betydelige lokalkommunale plan- og byggemodningsudfordringer, der fulgte af sommerhusbyspredningen, som samtidig rummede signifikante regionale udfordringer. Med sommerhusbyers stadig større udbredelse i hovedstadsmetropolens åbne opland blev disse i den første efterkrigstid ikke blot en udløber af metropolens stadig kraftigere industrialiseringsog urbaniseringsproces, men kom samtidig i langt højere grad til at indgå i den regionale interaktion mellem hovedstadsmetropolens øvrige funktionelt forskelligartede byenheder, der omfattede udveksling af arbejdskraft, varer, tjenester virksomheds-, bygge- og jordkapital, information og kulturer. En interaktion af forskellige produktionsfaktorer, varer og tjenester, der indebar, at barrierer og manglende rammebetingelser for denne udgjorde regionale udfordringer for hovedstadsmetropolens funktion som en byregion.

I forhold hertil kom den første efterkrigstids omfattede regionale sommerhusbyspredning til at skabe regionale barrierer for dels bygge- og jordkapitalens regionalt mest rationelle placering af arbejdskraftens sommerhuse og øvrige ferie- og fritidsbosætningsformer, dels industri- og forretningskapitalens mest hensigtsmæssige regional lokalisering af produktions- og servicevirksomheder i de dele af yderområder af hovedstademetropolen, hvor sommerhusbyerne lokaliseredes til, dels offentlige aktørers optimale regionale føring af trafik-, forsynings-, kommunikations- og spildevandslinjer. Barrierer, der var kritiske i forhold til interaktionen såvel i hovedstadsmetropolen som helhed som mellem sommerhusbyerne og andre funktionelt forskelligartede byenheder.

Sammen med de fjernere forstads- og pendlerbydannelser voksede de vidtstrakte sommerhusbyer på samme tid stadig længere ud i det åbne land, lagde beslag på, spærrede adgangen til og ødelagde kyst- og skovoplande, samtidig med at meget store og kompakt bebyggede sommerhusbyer mistede sin rekreative værdi for sommerhusejerne. ${ }^{56}$ Følgelig en yderlige begrænsning af de rekreative friluftsmuligheder, der var afgørende for metropolarbejdskraftens reproduktion og levevilkăr og dermed dens evne til at indgå $i$ hovedstadsmetropolens produktion og interaktion. En barriere for interaktionen $\mathrm{i}$ hovedstadsmetropolen, som yderlige forstærkedes af periodens glidende overgang til 
helårsbeboelse i sommerhuse, hvilket begrænsede denne mulighed for rekreative ferie- og fritidsophold, og genererede yderlige behov for sommerhusbyggeri med dermed følgende merbelastning af landskabelige værdier og rekreative områder. Samtidig en belastning for de stedlige sognekommuner, som måtte give samme velfærdsydelser- og tilbud til helårsbeboerne i sommerhuse som til de øvrige fastboede og stilledes overfor yderlige opgaver for så vidt vejog spildevandsanlæg.

Anlæg i den første efterkrigstids ekspanderende sommerhusbyer, som tillige skabte andre regionale udfordringer. Med privatbilens stadig større udbredelse måtte det regionale vejnet til og fra sommerhusbyerne, i ellers rurale områder, have en sådan kapacitet, at de kunne bære trafikken til disse byers befolkningskoncentrationer. Store sommerhusbyer, der samtidig med den stadig mere udbredte installation af wc og bad i sommerhuse udledte betydelige spildevandsmængder i forhold til de omgivende landdistrikter, hvis spildevandsafledningsforhold ofte var yderst primitive. Med privatbilismens belastning af hovedstadsmetropolens regionale vejnet og dens i forvejen meget betydelige regionale spildevandsafledningsudfordring, kom dens sommerhusbydannelser til at yde et yderligere substantielt bidrag. ${ }^{57}$

\section{Velfærdsstatens aktionsfelt}

I forhold til det stadig mere udvide aktionsfelt velfærdsstaten opnåede op gennem den første efterkrigstid, forstærkedes karateren af de bidrag, som periodens sommerhusbydannelser ydede til hovedstadsmetropolens i forvejen omfattende kompleks af regionale udfordringer; jf. APPENDIX I.B. Da hovedstadsmetropolen efter datidens vækstcenterteori udgjorde dynamoen for den økonomiske vækst, der var den økonomiske forudsætning for statsformen, og som skulle generere økonomisk vækst andre steder i landet, blev sommehusbyernes bidrag til barrierer for interaktionen i metropolen i sig selv kritisk. Det være sig de barrierer, som sommerhusbyerne var med til at lægge for kapitalens mest rationelle investeringer og offentlige aktørers linjeføring og konkrete udlæg af regionale trafik-, forsynings-, kommunikations- og spildevandslinjer.

\section{Velfærdstatens kultur- og fritidssøjle}

Som følge af de bredere samfundslags større fritid fik kultur- og fritidsområdet en endnu stærkere position blandt velfærdstatens bærende søjler i efterkrigstiden. En position, der afspejlede sig i oprettelsen af Kulturministeriet i 1961 , sidenhen ved etablering af særlige kultur- og fritidsforvaltninger i landets større bykommuner og afsættelse af flere midler på både statslige og kommunale budgetter til kultur- og fritidsformål. ${ }^{58}$ Umiddelbart efter oprettelsen af Kulturministeriet afstak dets først minister, socialdemokraten Julius Bomholt, linjen ministeriets virke til "under sin opbygning af et effektivt kulturelt demokrati" at have "to hovedopgaver: Den første er at støtte det skabende åndsliv", mens det andet "bliver at sikre at det enkelte medlem af samfundet făr adgang til kulturen". ${ }^{59}$ Kultur- og fritidspolitiske målsætninger, der tydeligt havde rødder i partiets visioner i mellemkrigstiden, og som med småjusteringer forsat gjorde sig gældende op gennem efterkrigstiden og kom til at omfattede offentlig støtte til kunstnerisk og kulturel produktion og en formidling heraf.

Produktionsstøtte bl.a. i form af Statens Kunstfond, statsstøtte til selvejende Dansk Forfatterfond, statslig tidskriftstøtte, ved siden af statslige orkestre, stats- og kommunest øtte til landdelsorkestre samt støtteordninger for teater- og filmproduktion. Ved siden af de store statslige kulturinstitutioner, statslig radio og senere tv, kunst- og kulturformidling via en massiv udvidelse af folkebibliotekssektoren, fritidsundervisning med udvidet folkeoplysning og flere kommunale aften- og ungdomsskoletilbud, bedre fysiske rammer for idrætsliv, kommunale og statslige støtteordninger til forskellige former for museer, arkiver, teatre samt aktiviteter og arrangementer, som det store antal fritidsorganisationer stod bag. Dispositioner med det fælles formål at kæde den øgede fritid sammen med en større og bredere tilgængelighed for alle til kulturlivets goder med et bredt demokratisk folkeoplysende sigte.

Men også dispositioner, der af hensyn til fritidens friluftsliv op gennem efterkrigstiden bl.a. førte til: Dels grønne rekreative kiler mellem de radiale forstandsbånd, som kom til at kendetegne hovedstadsmetropolens regionalt planlagte forstadsdannelser. Dels tværgående grønne bælter mellem forstadsbåndene. Dels kunstigt anlagte naturområder så som Vestskoven og Køge Bugt Strandpark. Dels betydelige rekreative arealudlæg i det nordligste Nordsjælland, Hornsherred og skov- og naturområderne syd herfor og i retning mod Køge; jf. Kapitel 9.60

Mest kritisk blev i en velfærdsstatslig sammenhæng sommerhusbyernes udbredelse i det åbne land, ødelæggelser af dettes kultur- og naturhistoriske værdier og afspærring og reduktion af tilgængelige rekreative områder for almenheden. Med den øgede fritid, der opnåedes gennem 
ferieloven af 1938 og arbejdsmarkedets overenskomster, var kultur- og fritidsområdet, som anført i DEL II, allerede i slutningen af mellemkrigstiden blevet omfavnet af velfærdsstaten. Målet blev via det offentlige at give de brede samfundslag samme adgang til de kultur- og fritidstilbud, som borgerskabet hidtil havde nydt godt af, for ad den vej at skabe større social lighed.

Målsætningen opretholdtes op gennem efterkrigstiden, men blev som på andre velfærdsområder mere universalistisk. Spektret for de kultur- og fritidspolitiske initiativer udvidedes og kombineredes, men centralt forblev bestræbelserne for at bidrage til de brede samfundslags fysiske og intellektuelle højnelse bl.a. gennem forskellige former for friluftsliv $i$ rekreative områder. Det være sig den enkeltes frie udfoldelse i sådanne områder eller mere organiseret i kolonihaver, på campingpladser eller i almennyttige feriecentret, der samlet repræsenterede et alternativ til de mere velbjergedes sommerhuse. ${ }^{61}$

\section{Den politisk-administrative rammestruktur}

I forhold til den buket af udfordringer, som opstod i takt med sommerhusbyernes stadig større udbredelse i hovedstadsmetropolens åbne land, stilledes de stedlige sognekommuner og senere rurale primærkommuner i den første efterkrigstid overfor betydelige lokale plan- og byggemodningsudfordring for så vidt tilsagn ved godkendelse af udstykningsplaner, vejudlæg, bedømmelses af forhold af byggeteknisk karakter, ordning af vandindvindings- og spildevandsafledningsforhold, byplanmæssige dispositioner m.m.

Selv om mange sommerhuskommuner med mindre end fire fastboende pr. sommerhus i 60 'erne, i takt med udfasning af det lovfastsatte forhold mellem ligning på henholdsvis jord og indkomst, hævede grundskyldspromillens størrelse og bidragene til de amtskommunale fonde, der bl.a. beregnedes ud fra grundværdierne, til gunst for den lokalkommunale økonomi eller nedsættelse af de fastboendes kommunale indkomstskat, fik de plan- og byggemodningsomkostninger, der fulgte med de omfattende sommerhusbydannelser, en betydelig tyngde. ${ }^{62}$ En omkostningstyngde, der svarende til dem, som kommunerne i den indre del af hovedstadsmetropolen stod overfor ved overgangen fra land til forstad, og som skabte uensartede kommunaløkonomiske vilkår i metropolen, hvilket i sig selv udgjorde en regionaludfordring.

Skønt mange af sommerhussognekommunerne særlig i 60 'erne i et vist omfang fik forbedrede muligheder for at håndtere de lokale udfordringer, der knyttede sig til den første efterkrigstids sommerhusbydannelser, APPENDIX VII, blev deres udbredelse over stadig flere kommuner og større dele af det åbne land tillige en regional politisk-administrativ udfordring. Som for hovedstadsmetropolens øvrige regionsudfordringer blev det i forhold til dem, der også skabtes af sommerhusbydannelserne spørgsmålet, hvorvidt og i hvilket omfang staten eller metropolens kommunale politisk-administrative rammestruktur havde evnen eller muligheden for at håndtere disse.

Med hovedstadsmetropolens stadig større udbredelses i den første efterkrigstid forstærkedes dens kommunestruktur på samme tid som en selvstændig regional udfordring. Hovedstadskommissionen fra 1938 havde ganske vist i sin betænkning fra 1948 lagt op til forandring af denne struktur i forhold til hovedstadsmetropolens lokale og regionale udfordringer, men dens indstilling og det efterfølgende politiske spil blev så mudret, at Rigsdagen stiltiende ved en opgradering af de indre forstadskommuner til en semikøbstadskommunal status i 1952 tilsluttede sig den skitse til en decentral hovedstadsordning, som regeringen fremsatte på samme tid. ${ }^{63}$

Ud over den nævnte opgradering, fastholdt ordningen hovedstadsmetropolens hidtidige forstads-, hovedstads-, købstads- og amtskommunale opgavefordeling og inddeling, og rummede ikke som Hovedstadskommissionens betænkning et regionalkommunalt organ til varetagelse af metropolens regionale udfordringer. Disse blev i den decentrale 
hovedstadsordning overladt til en særlig hovedstadskonference, hvor hovedstadsmetropolens forstads-, hovedstads-, købstads- og amtskommuner kunne drøfte forslag til regionale løsninger, herunder oprettelses af et kommunalt regionsorgan, som så efterfølgende skulle kunne danne grundlag for den nødvendige lovgivning. Da denne konference, i form af i 1956 nedsatte Hovedstadskommunerne Samråd, i realiteten intet opnåede, blev en væsentlig del af hovedstadsmetropolens regionsudfordringer overladt til de etapevise statslige regionsløsninger, som tillige indgik i den decentrale hovedstadsordning. Af disse blev egnsplanlægning, herunder fredningsplanlægning, en af de betydeligste, der samtidig fik indvirkning på den regionale udfordring, som den første efterkrigstids sommerhusbyspredning $\mathrm{i}$ hovedstadsmetropolens åbne land udgjorde. ${ }^{64}$ 


\section{Egnsplanlægning}

Da hovedstadsmetropolens allerede stedfundne og forventede regionale byspredning ikke kunne planlægges inden for de lokalkommunale planrammer, som 1938-byplanloven udstak, genindkaldtes i 1945 Egnsplanudvalget; jf. Del II, Kapitel 7. Tre år efter fremlagede udvalgets Egnsplankontor den såkaldte Fingerplan, der ganske vist ikke blev vedtaget som en bindende regional plan, men i udstrakt grad blev rammesættende for de egnsplanmæssige dispositioner i de følgende ti år.

\section{Under Fingerplanen, 1948-1961}

Fingerplanen brød med både hovedstadens og de omliggende forstæders hidtidige koncentriske lagvise byspredning og lagde op til herfra gående radiale forstadsbånd $i$ et bælte omkring eksisterende og kommende S-baner med en rummelighed, der i 1975 ville kunne bære en befolkningstilvækst på 400.000, hvorved hovedstadsmetropolens folketal dette år ville nå 1,5 mio. mod 1,1 , mio. i 45.65

\section{Fingerplanen}

Ved hver S-banestation skulle der dannes stationscentre, som ville blive kernen i hver af de enkelte forstadsbyer. I tilknytning til dette lokalcenter skulle der opføres etagehuse og længere ude enfamilies- eller rækkehuse samt, i særlige zoner, let industri, men forstadsbåndet måtte ikke blive bredere, end der højest var en gangafstand på 10-15 minutter til S-banestationen eller de omgivende ubebyggede kiler, der lå mellem forstadsbåndene. En af byerne i hvert forstandsbånd, Jægersborg, det vestlige Gladsaxe, Herlev, Glostrup-Brødbyerne og Avedøre, skulle desuden huse en zone for ny tung industri, mens det inderste stationscenter i hvert af forstadsbåndene tillige skulle rumme offentlige institutioner, forretninger og servicefunktioner af betydning for hvert af forstadsbåndene og således fungere som en art storcenter til aflastning af Københavns indre by.

For her at skaffe de nødvendige rekreative arealer for den kommende befolkningstilvækst, opstillede Fingerplanen forskellige muligheder, som offentlige myndigheder måtte tage i anvendelse: Dels anlæggelse af kunstigt skabte naturområder til rekreative formål i form af bl.a. anlæg af skovområder på Vestegnen. Dels rekreativ indtænkning af kilerne mellem forstadsbåndene, der ikke blot skulle anvendes til fortsat landbrug til hovedstadsmetropolens forsyning, men i vidt omfang skulle udlægges med stianlæg, folkeparker, prydanlæg, kolonihaver eller idrætsanlæg. Kilerne burde føres dybt ind i hovedstadsmetropolen og så nær grænsen til de ældre og koncentriske forstadsdannelser som muligt, og ville med den korte afstand til S-banestationerne tillige kunne fungere som rekreative områder for de mere tæt bebyggede dele af hovedstadsmetropolen. 66

Da Fingerplanens for så vidt øvrige rekreative arealudlæg alene omfattede en fuldstændig gennemførelse af de forslag, der indgik i Den grønne Betænkning, og som ikke kom med i 1940-fredningsplanen, blev det blot til anbefalinger om at udvide det igangværende fredningsplanarbejde til at omfatte hele Nordsjælland, Hornsherred og det syd for liggende skovrige område, der strakte sig mod øst i retning mod Køge. Nærmere regionale planretningslinjer for Kattegatkystens sommerhusbybælte og de øvrige dele af hovedstadsmetropolens åbne land, der snart ville blive omfattet af nye sommerhusbydannelser, indgik således ikke i Fingerplanen.

For Køge Bugt-området gav Fingerplan dog konkrete retningslinjer for, at der syd for en kommende S-bane og et fremtidigt forstadsbånd til Vallensbæk, skulle udlægges et nyt regionalt sommerland for hovedstadsmetropolen - eller "et fritids- og friluftscenter - et Sydkystens Klampenborg", som det udtryktes. ${ }^{67}$ Ved bugtens kyst skulle der således udlægges storstilede badestrande gennem sandopfyldning med tilhørende lejrpladser og strand- og 
folkeparker. Herudover skulle den sydlige del af Køge Bugts sommerhusbybælte bevares og udbygges som den nærmeste sommerhusby i hovedstadsmetropolen. ${ }^{68}$

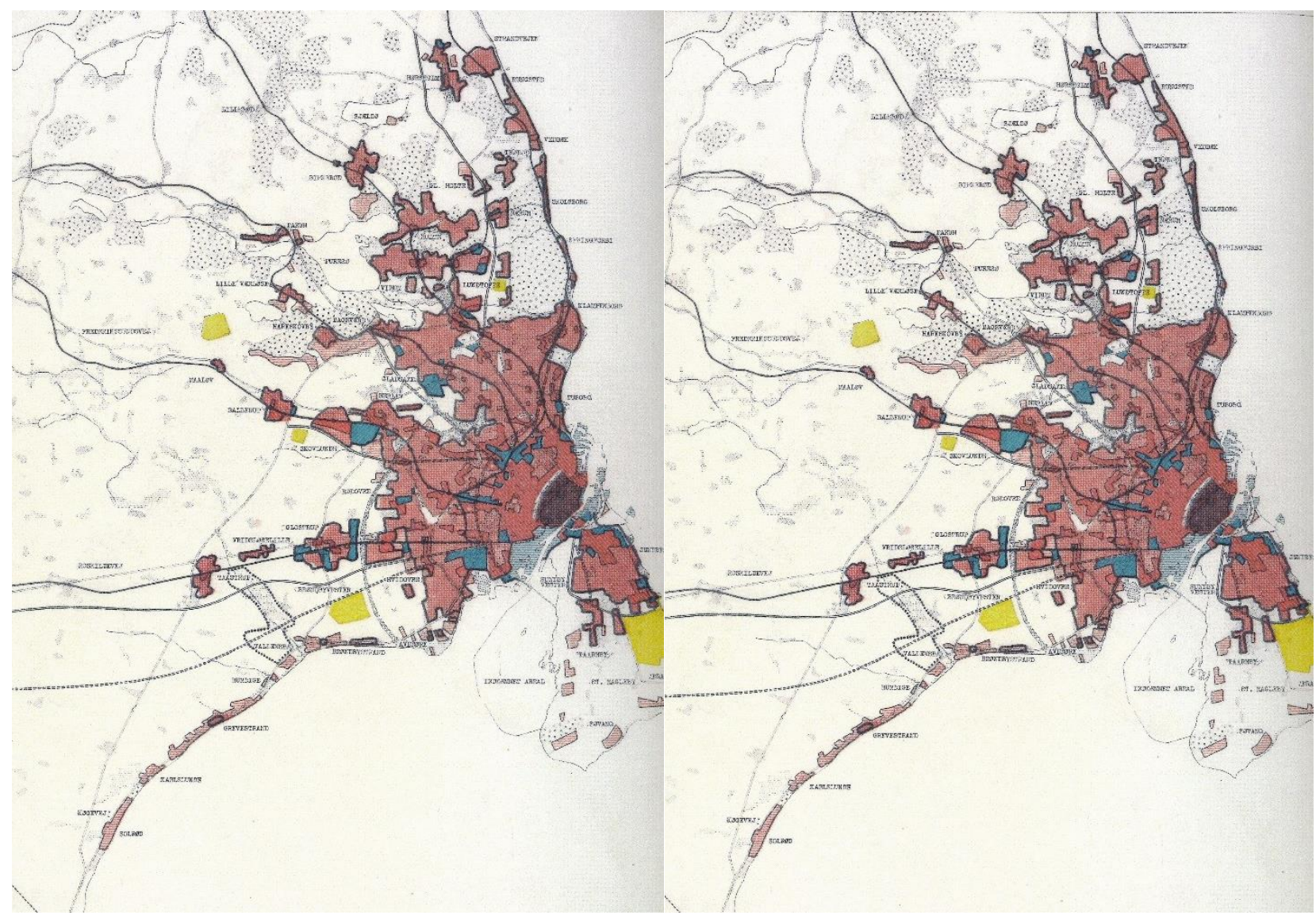

Fingerplanen første etape, til venstre og anden etape, til højre (Fingerplanen 1948)

\section{Statslige egnsplanorganer}

Da en markant afgrænsning af hovedstadsmetropolens regionalt planløse byspredning gennemsyrede Fingerplanen, og fænomenet i mindre omfang også gjorde sig gældende omkring landets store og større købstæder, gennemførtes i 1949 den såkaldte byudviklingslov. Loven, der senere i den decentrale hovedstadsordning fra 1952 blev indskrevet som en af de etapevist statsligt tilvejebragte rammebetingelser for hovedstadsmetropolens funktion som en byregion, gav inden for udstukne byudviklingsområder statslige byudviklingsudvalg mulighed for via byudviklingsplaner at afstikke disse byvækstgrænser gennem særlige zoneudlæg i form af: Inderzoner, der var trafikbetjent og bygge modnet, og hvor byudvikling og bebyggelse var tilladt, yderzoner, hvor kun landbrugsbyggeri måtte finde sted samt mellemzoner, der ved senere trafikbetjening og byggemodning kunne overgå til inderzone, og hvor det var muligt for mindre bemidlede at opkøbe byggegrunde, således at disse kunne lægge midler til side med henblik på et senere byggeri.

I yderzoner kunne der dog gives tilladelse til opførelse af sommerhuse på betingelse af, at der lystes en deklaration om, at husene udover kortvarige ferie- og weekendophold kun måtte bebos i perioden 1.4-30.9., og at brugeren havde helårsbeboelse andet steds. Herudover skulle, der for godkendte sommerområder i yderzoner fra kommunernes side gennemføres bygnings- og byplanmæssige bestemmelser. Målet var dels at sikre en tidsvarende og tilstrækkelig bygningstekniske standard, dels at hindre, at sommerhusbyer de facto udviklede sig til egentlige bydannelser, hvilket ville komme på tværs af byudviklingsplanerne intentioner om at afgrænse byspredningen. 
Da udvalgene ud over disse zoneudlæg de jura ikke havde mulighed for at disponere regionalt byplanmæssigt, gennemførtes samtidig med byudviklingsloven en ændring af 1938byplanloven, der dels muliggjorde en samordning af byplanlægning på tværs af kommunegrænser via særlige samordningsudvalg, som Boligministeriet fik mulighed for at nedsætte, der opdelte Byplannævnet i en særlig Hovedstadsafdeling og en Provinsafdeling.

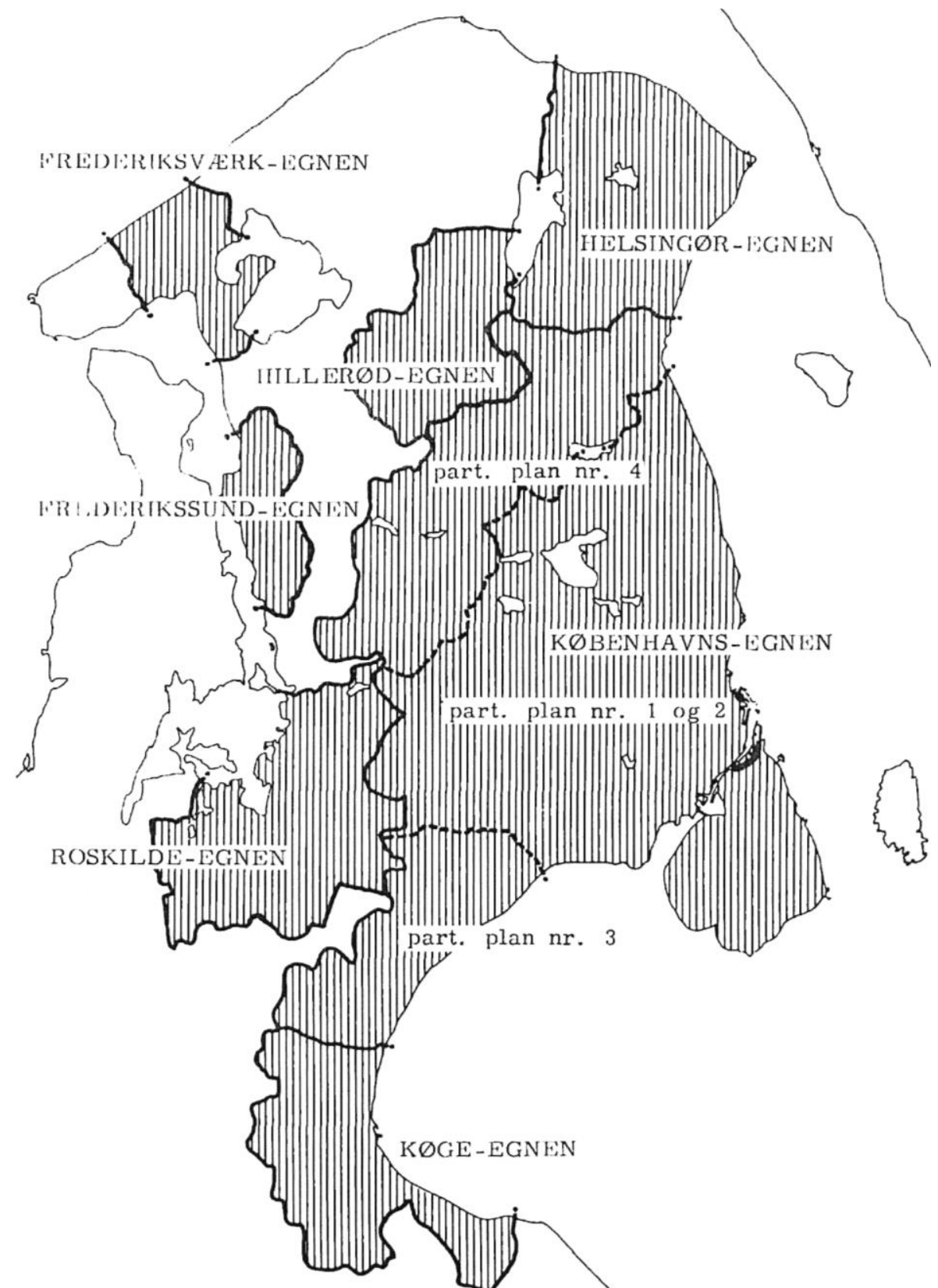

Byudviklingsområder i Nordøstsjælland 1960 (Betænkning vedrørende partiel byudviklingsplan nr. 5 for Københavnsegnen byudviklingsområde, afgivet den 14. juli 1961 af det af boligministeren den 2. juli 1957 nedsatte byudviklingsudvalg for Københavns-egnen, 1961, s. 4)

Straks efter gennemførelsen af byudviklingsloven nedsattes et byudviklingsudvalg for Københavns-egnen. Snart omfattende hovedstaden, samtlige kommuner i Københavns Amtskommune, de fire sydligste sognekommuner langs Køge Bugt i Roskilde amtskommune samt et større antal af de sydligste sognekommuner i Frederiksborg Amtskommune. Af frygt for den byspedning, som hovedstadsmetropolen ville generere uden for Københavns-egnens byudviklingsområde, og den, der ville udgå fra købstæderne i den omliggende købstadsring, 
blev hver af egnene omkring disse byer frem mod starten af 60 'erne tillige udlagt til byudviklingsområder med tilhørende byudviklingsudvalg.

Med de nævnte organer blev der sammen med først fredningsplansudvalget for den indre del af hovedstadsmetropolen og fra 1959 med fredningsplanudvalget for hele metropolen, jf. Kapitel 9, etableret statsadministrative rammer for regionsplanmæssige dispositioner $i$ hovedstadsmetropolen. Mens byudviklingsudvalgene skulle afgrænse byspredningen, og fredningsplanudvalget reservere områder af rekreative og naturbeskyttende hensyn, opbyggedes der med Byplansnævnets Hovedstadsafdeling og med medvirken af Byudviklingsudvalget for Københavns-egnen en regional byplanadministrativ koordinaturstruktur, der ved de konkrete dispositioner tog udgangspunkt i de regionale byplanmæssige pejlemærker, som Fingerplanen havde udstukket. ${ }^{69}$

\section{Regionale byudviklingsplaner}

I et tæet samarbejde med fredningsudvalget gennemførte Byudviklingsudvalget for Københavns-egnen frem til starten af 60 ' erne flere byudviklingsplaner for dettes byudviklingsområde og administrerede efterfølgende byspredningen inden for de udlagte zoner. Med en gyldighedsperiode frem til 1966 lagde en byudviklingsplan fra 1951 ud fra Fingerplanens retningslinjer de bymæssige grænser for forstadsudviklingen i hovedstadsmetropolens indre del. Skønt 1951-byudviklingsplanen kom til at opdele metropolforstæderne i inder- og mellemzoneområder, der senere muliggjorde en by- og befolkningstilvækst, som langt oversteg de rammer, der var nedlagt i Fingerplanen nogle år tidligere, afspejlede planens struktur sig tydeligt i den stedfundne byvækst, som byudviklingsplanen lagde rammer for:

Således et sammenhængende og kompakt byområde bestående af hovedstaden og det ude om liggende ældre lag af forstæder, uden for radiale forstadsdannelser langs eksisterende og kommende S-baner og udstrakte, dybe og mellemliggende kiler. Radiale forstadsdannelser, dels hvor eventuelt sommerhusbyggeri i yderzoneområderne i de mellemliggende kiler eller $\mathrm{i}$ rekreative områder underlagt efter 1940 -fredningsplanen blev umuliggjort, dels inkluderende sommerhusbyerne i den indre del af Køge Bugt-området ved Brøndby og Vallensbæk strande. En naturlig følge af at et større byggeri af helårsenfamiliehuse allerede her var påbegyndt på ledige byggegrunde eller til erstatning af ældre sommerhuse.

Som følge af at der i den første del af 50 ' erne var usikkerhed om tidspunktet for påbegyndelsen af S-banen langs Køge Bugt, og i øvrigt også af den senere Køge Bugtmotorvej, var Køge Bugt-området ud fra Fingerplanens præmisser trods nærheden til den $\varnothing v$ rige hovedstadsmetropol foreløbig uegnet til forstadsomdannelse. Af den grund og for ikke at spolere mulighederne for en kommende samlet planlægning af det meget store og i det væsentligste ubebyggede sydligere Køge Bugt-område, var Byudviklingsudvalget for Københavns-egnen i en byudviklingsplan fra 1954 for Ishøj-Torslunde Sognekommune og de syd for liggende sognekommuner i Roskilde Amtskommuner yderst restriktiv med udlæggelse af de bymæssige inder- og mellemzoner. I første omgang blev det kun til et smalt bybælte omsluttende Køgevejen med mulighed for en mere udbredt helårshusbebyggelse i den nordlige del ved Ishøj, Hundige og Greve strande, hvor omdannelsen fra sommerhusby til forstad dermed for alvor kunne indledes.

Da privatbilismen endnu ikke var blevet udbredt i større omfang, og da Byudviklingsudvalget for Købenavns-egnen skønnede, at der var behov for en nærmere hovedstadsmetropolen beliggende sommerhusby, fastholdt 1954-byudviklingsplanen i overensstemmelse med Fingerplanen sommerhusbybæltet i den sydligste del af Køge Bugt-området. Her kunne der på tilbageværende udstykkede ledige parceller opføres sommerhus så længe, de ikke kom i konflikt med 1940-fredningsplanen og afstandsbestemmelserne i forhold til kystlinjen. Med disse forbehold og da det omgivende åbne land blev udlagt som yderzone, hindrede 1954byudviklingsplanen de facto en yderligere udvidelse af Køge Bugts sydligste sommerhusbyer. 
Mens det således i den indre del af hovedstadsmetropolen i 50'erne gennem byudviklingsplaner og 1940-fredninsgplanen lykkedes at inddæmme dannelsen af nye sommerhusbyer og udvidelse af eksisterende, blev der i dette årti og til et godt stykke op i 60'erne ikke givet disse muligheder i metropolens ydre åbne opland. Dér hvor eksisterende sommerhusbyer ekspanderede voldsomt, og et stort antal nye sommerhusbyer voksede op. Det gjaldt byudviklingsområderne for Helsingør-, Roskilde-, og Køge-egnene, hvor arbejdet med byudviklingsplanerne først påbegyndtes i løbet af den sidste del af 50 'erne, men hvor de stedlige byudviklingsudvalg samtidig endnu ikke anså købstæderne og deres oplande som en del af hovedstadsmetropolen.

Der lagdes vægt på, at købstæderne hidtil havde haft deres egen industrielle udvikling og naturlige vækstgrundlag som følge af det økonomiske samspil med oplandet, hvorfor de mere beherskede inder- og mellemzoner omkring købstæderne og oplandenes landsbyer udlagdes på grundlag af disse præmisser, og de uden om liggende yderzoner blev relativt smalle, og dermed ikke rakte længere ud i købstædernes oplande. Hertil føjede sig, at nødvendigt udvidede byudviklingsplaner for egnene omkring Helsingør, Hillerød, Roskilde og Køge i starten af 60 'erne endnu ikke var indsendt til godkendelse i Byplannævnet, og at byudviklingsplanarbejdet for Frederiksunds- og Frederiksværksegnene, der ikke omfattede Hornsherred og hele Roskildes Fjords nord- og østkyst, først lige var påbegyndt. ${ }^{70}$

\section{Under Principskitsen og Første Etapeplanen, 1961-1974}

Da Egnsplankontoret indstillede sin virksomhed ved årsskiftet 1949/50 umiddelbart efter nedsættelsen af Byudviklingsudvalget for Københavns-egnen, standsedes videreudvikling og justeringen Fingerplanen op igennem 50 'erne, hvor netop en række af dens forudsætninger så ud til at briste. Allerede i 1957 passeredes de 1,3 mio. indbyggere, som Fingerplanen forventede, at hovedstadsmetropolen først ville nå i løbet af den første halvdel af 60 'erne, og helt modsat end forudsat var folketallet i hovedstaden faldet med 30.000. Med den samtidige større tilflytning fra provinsen gav det et yderligere pres på forstadsområderne, hvor Fingerplanens udstukne bebyggelsesrammer opfyldtes hurtigere, end planen forudsatte, og i en sådan grad, at metropolen begyndte at brede sig mere ind i de tilstødende amtskommuner. En kraftigere befolkningstilvækst og-forskydning end forudset lå bag, hvortil kom den større mobilitet og de forøgede muligheder for byspredning, der fulgte med den stærkt forøgede privatbilisme. Oveni kom så et arealbehov, der oversteg Fingerplanens prognoser, og som blev genereret af parcelbyggeri, et større boligforbrug, som konsekvenser af flere små husstande, en industriudflytning til og anlæg af nye produktionsvirksomheder i forstæderne af et samlet arealmæssigt omfang, som planen, med samtidens præmisser, ikke kunne have forudset.

\section{Principskitse og Første Etapeplan}

Da metropolens byvækst i slutningen af 50 'erne således så ud til at sprænge Fingerplanens udstukne rammer, foranledige Hovedstadskommunernes Samråd Boligministeriet til at tage initiativ til oprettesen af Egnsplansekretariatet for Storkøbenhavn, der i 1958 trådte i funktion under Byplannævnets Hovedstadsafdeling. I 1961 fremlagde Egnsplansekretariatet den såkaldte Principskitse, der $\mathrm{i}$ endnu højere grad end Fingerplanen indlagde meget markante vækstparametre i planlægningen af hovedstadsmetropolen. Skitsen forudsatte således, at metropolen, som nu kom til at omfatte hovedstaden og de tre hovedstadsamtskommuner, $\mathrm{i}$ 1980 ville nå et befolkningstal på 2 mio., som frem til år 2000 ville stige til 2,5 mio. Med en befolkningsforøgelse på 1 mio. og ud fra et betydeligt arealbehov til bolig-, erhvervs- og institutionsbyggeri samt rekreative områder, lagde egnsplanen i Principskitsen op til en tredobling af hovedstadsmetropolens byareal.

I den første fase frem til 1980 skulle der inden for hovedstadsmetropolens daværende indre område ske en udbygning af forstadsbåndene inden for de udlagte inder- og mellemzoner, dog således at forstadsfingrene langs Vestbanen og Køge Bugt ville blive noget bredere og forlænget i retning mod Roskilde og Køge, mens de øvrige forstæder i højere grad blev friholdt for byvækst. Herudover skulle der gennemføres en noget større bebyggelse i de sydøstlige forstadskommuner i Frederiksborg 
Amtskommune og omkring købstæderne Helsingør, Hillerød og Frederikssund og en betragtelig udvidelse af købstæderne Roskilde og Køge. For at dække størstedelen af hovedstadsmetropolens estimerede befolkningstilvækst og arealbehov, forestillede Principskitsen sig dannelsen frem til 1980 af to og frem til år 2000 yderligere to helt nye byenheder på hver samlet 200.000-250.000 indbyggere. Da hovedstadsmetropolens vækst med de forlængede forstadsfingre allerede var tænkt placeret i dens sydvestlige del, skitserede Principskitsen en løselig placering af de store byenheder $\mathrm{i}$ området mellem to fingre.

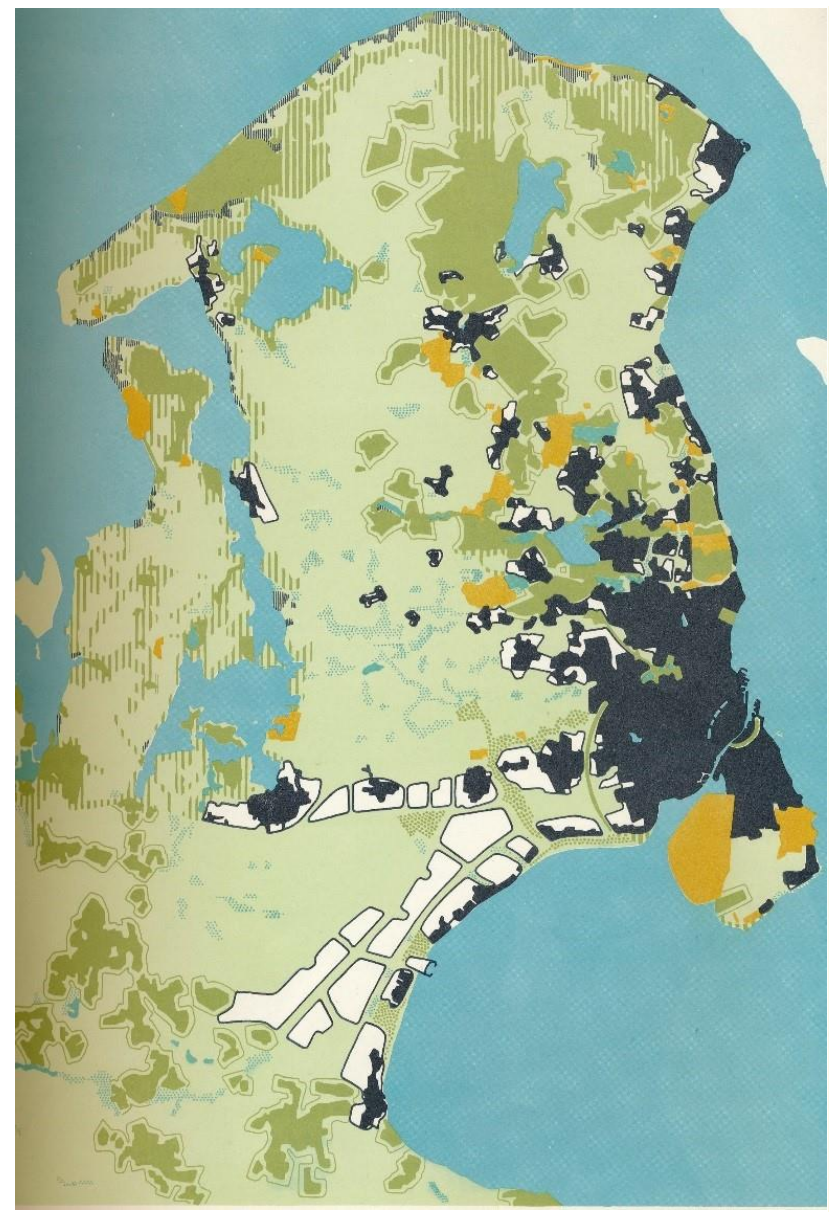

SIGNATURER.

Principskitsens byområder

Eksisterende helårsbebyggelse

Eksisterende sommerhusbebyggelse

Skove og endelige fredninger

(kontur om skove angiver $300 \mathrm{~m}$ beltet)

Forslag til skovplantninger og til anlæg

af større strandområder

Godkendte fredningsplanarealer

Skitserede fredningsplanarealer

Større statsarealer bortset fra skove
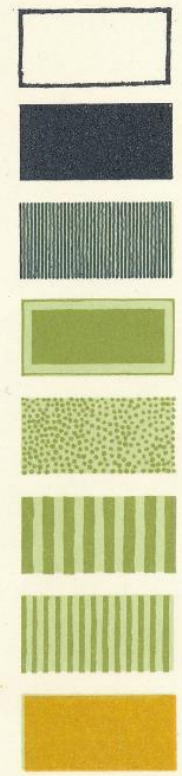

Mosedrag

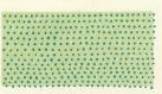

Principskitsen fra 1960 (Principskitse til egnsplan, Egnsplansekretariatet, 1960)

Trods tidens tro på økonomisk og bymæssig vækst og den betydning den tillagdes i

vækstcenterteorien, mødte byvolumenet i Principskitsen en så udtalt kritik, at skitsen blev beskåret af Boligministeriet, og fik den form, som den i 1963 fremlagdes under betegnelsen Første Etapeplanen. Planen, der fik en gyldighed til frem til starten af 70'erne, lagde, trods beskæringen, med en rummelighed, svarende til en kvart million nye boliger, op til en betydelige vækst, der tænktes fordelt indenfor hovedstadsmetropolens forstadsbånd og i særlig grad i de samme forlængede bånd langs Vestbanen og Køge Bugt, som Principskitsen også opererede med. Udover nogen byvækst omring købstæderne i købstadsringen skulle den sydvestlige del af det indre metropolområde dermed bære en væsentlig del af byvæksten og dermed også de betydelige nye industrizoner, som Første Etapeplanen lagde op til, samt to storcentre, der skulle etableres i Høje Tåstrup og Hundige. Et tredje tænktes placeret i den gamle Lyngby stationsby. ${ }^{71}$

Mens en del af Fingerplanens rekreative forslag, for så vidt den indre del af hovedstadsmetropolen, i vid udstrækning satte sig spor i den første efterkrigstids stadig flere fredningsplaner, forblev planens grønne kiler og andre rekreative områder, der ikke umiddelbart kunne underkastes egentlig naturfredning, et centralt element i både Principskitsen, Første Etapeplanen og Køge Bugt- 
dispositionsplanen, se nedenfor. Ganske betydelig områder, der således forsat reserveredes til de i Fingerplanen tiltænkte formål og dermed friholdtes for sommerhusbebyggelse. Selv om hverken Principskitsen eller Første Etapeplanen nærmere præciserede omfanget af kommende sommerhusbyer i hovedstadsmetropolens ydre opland, udlagde de på grundlag af det i gangværende arbejde i metropolens udvidede fredningsplansudvalg, se nedenfor, op til udlæg af kolossale rekreative fredningsområder op til Kattegatkystens eksisterende sommerhusbybælte, langs Roskildes Fjords østkyst, i hele Hornsherred og i de skovområder, der syd for strakte sig i retning mod Køge. ${ }^{72}$

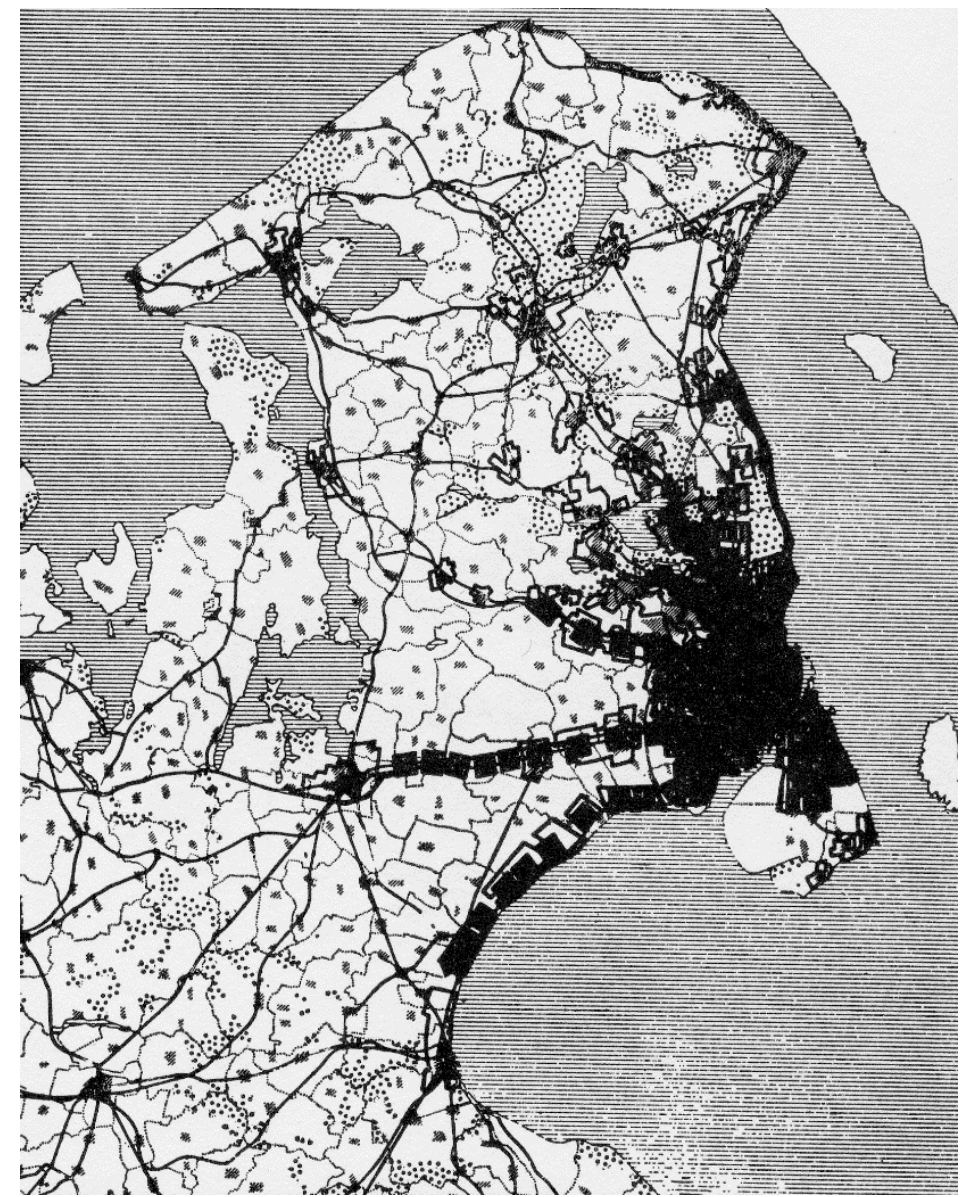

Teknikerudvalgets førsteetapeplan for hovedstadsmetropolens udvikling fra 1963. (Hovedstadskommunernes Samrådsmøde 20.11.1963, J.nr. 120I, 1982, Sekretariatet, Frederiksberg Stadsarkiv)

\section{Udvidet byudviklingsplanlægning}

Da først Principskitsen og siden Første Etapeplan helt entydigt havde lokaliseret hovedstadsmetropolens kommende vækstområde til dens indre sydvestlige del, var strømpilen lagt for de videre regionale plandispositioner, der nærmere blev rammesat af Første Etapeplan, som med godkendelsen fra Byplannævnets Hovedstadsafdeling de facto blev hovedstadsmetropolens regionsplan og grundlaget for byudviklingsplanlægningen for de følgende godt 10 år.

I lyset af, at de trafikale forudsætninger for en omfattende forstadsdannelse i det store Køge Bugtområde ville blive tilvejebragt inden for en kortere årrække, påbegyndte Byudviklingsudvalget for Københavns-egnen i foråret 1960 arbejdet med at udlægge de inder- og mellemzoner, der kunne rumme de nye forstæder, samtidig med at der fremsattes forslag til en særlig lov, der skulle sikre en samlet helhedsorienteret planlægning af bebyggelsen i det store i det væsentligste stadig ubebyggede mråde. I forlængelse af loven i 1961 nedsattes et særligt planlægningsudvalg for Køge Bugt-området, der, inden for de nu udvidede grænser for byvæksten, som byudviklingsudvalget havde lagt, og ud fra dets bebyggelsesplanmæssige forslag i den ledsagende betænkning, i 1966 fremlagde en samlet dispositionsplan, som med Boligministeriets godkendelse i 68 blev bindende for lokalkommunerne. 
Planen udstak et forstadsbånd fra Avedøre i nord til Jersie Strand i syd, der afgrænset af kystlinjen og den senere Køge Bugt-motorvej, bestod af 10 selvbærende stationsnære byenheder med betydelige stationscentre ved hver station og omgivende kvarterer med etagehuse. Længere ude med lav og åben bebyggelse med parcel- og rækkehuse og på den anden side af motorvejen et smalt industribælte fra Ishøj og ned til Karlslunde. I Køge Bugt-planen indgik samtidig meget betydelige rekreative områder i form af den senere Køge Bugt Strandpark og en grøn kile mellem de senere Holbæk- og Køge Bugt-motorveje, der, uden sommerhusbyggeri, syd for bredte sig ud i det åbne land mellem Køge Bugts og Vestbanens ydre forstadsfingre. Med Køge Bugt-planen, der gennemførtes fra slutningen af 60 'erne og op gennem den sidste efterkrigstid, omdannedes de sydligste sommerhusbyer til villakvarterer. Omdannelsen til forstad havde her allerede taget sin begyndelse i starten af 60'erne, og blev med Køge Bugt-planen hurtigt afsluttet, hvorved Køge Bugt, stik i mod Fingerplanens oplæg, endelig gled ud af rækken af hovedstadsmetropolens sommerhusbyer.

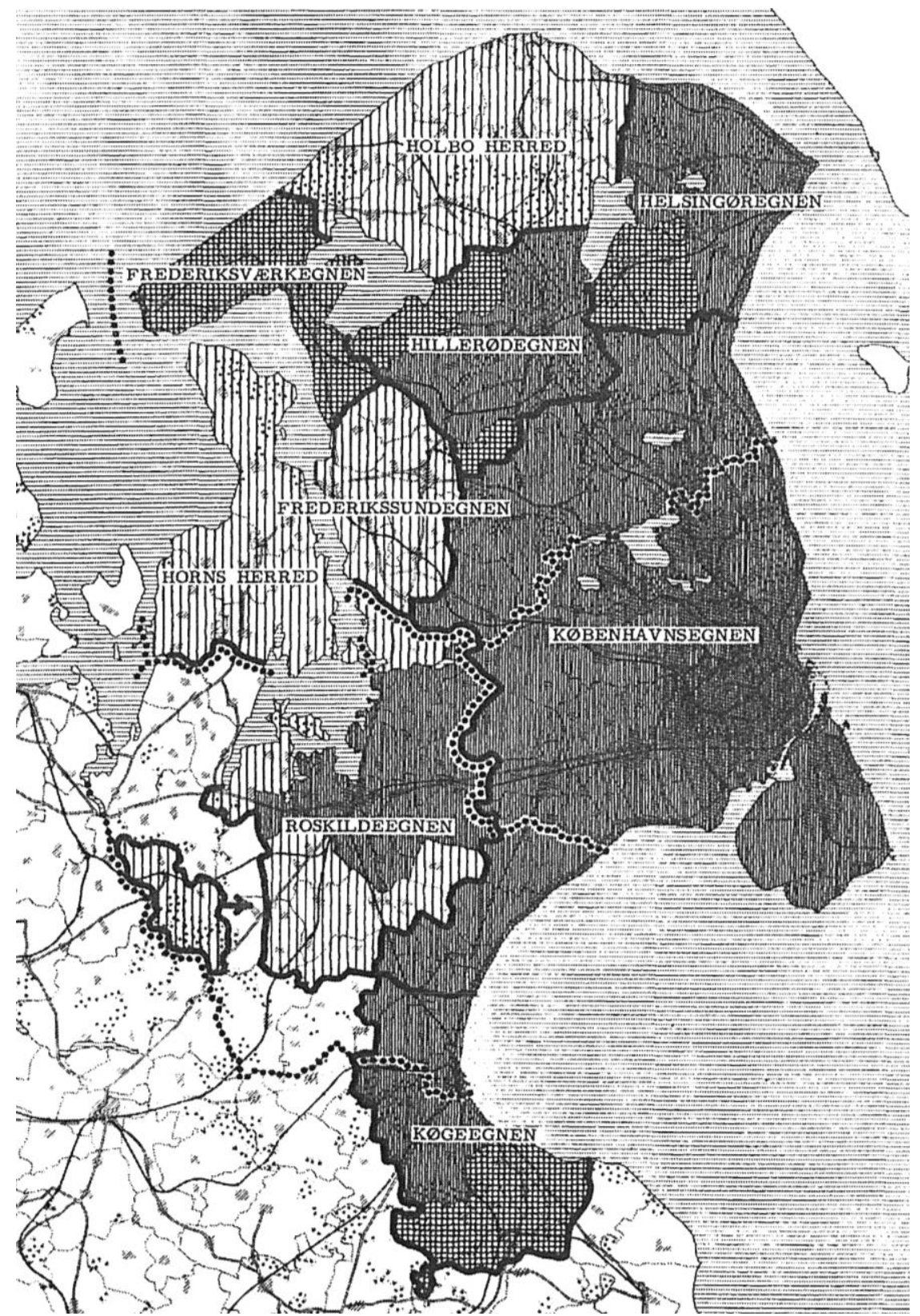

Byudviklingsområder i Nordøstsjælland 1965 (Betænkning vedrørende partiel byudviklingsplan nr. 6 for Københavns-egnens byudviklingsområde afgivet den 7. oktober af det af Boligministeriet den 2. juli 1957 nedsatte byudviklingsudvalg for Københavns-egnen, 1965, s. 14) 
Ved reviderede byudviklingsplaner fra årene 1960-1967 lagde Byudviklingsudvalget for Københavnsegnen ud fra Første Etapeplan, på ny i et tæt samarbejde med fredningsplanudvalget, se nedenfor, rammer for byvæksten i de sidste og yderste dele af de øvrige forstæder i den indre del af hovedstadsmetropolen. Samme med de yderzoner, som udvalget siden 1951-byudviklingsplanen havde måttet inddrage til navnlig industri, og en af de reviderede byudviklingsplaners udlæggelse af yderligere mellemzoner i Nordvest- og Vestegnen, blev forstadsbåndene langs Vestbanen og Frederikssundsbanen bredere end forudsat i særlig Fingerplanen og i nogen grad også i Første Etapeplan, mens de nye forlængede forstadsfingre vest for Tåstrup og Ballerup blev så smalle, at de opfyldte det stationsnærhedsprincip, som var nedlagt i både Fingerplanen og i Første Etapeplan. ${ }^{73}$

Da de sydlige og østlige forstæder på Nordegnen var bebygget langt tidligere end den øvrige del af den indre hovedstadsmetropol, og Første Etapeplan samtidig lagde op til en yderst begrænset byvækst i egnen, blev de her tilbageværende udstykkede og fuldt byggemodnede områder i en anden revideret byudviklingsplaner udlagt som inderzone, der alene fik tillagt meget små nye mellemzoneområder. Egnens største nye inder- og mellemzoner blev derfor udlagt omkring Lille Værløse og Farum, hvor forstadsdannelsen først havde taget sin begyndelse i løbet af 50 ' erne. ${ }^{74}$

For det nærmeste uden for forstæderne på Nordegnen beliggende delbyudviklingsområde, omfattende et bælte mellem Stenløse og Veksø i sydvest, strækkende sig over til Ganløse, Lynge, Allerød og Blovstrød til Kokkedal og Nivå mod nordøst, havde Byudviklingsudvalget for Københavns-egnen allerede i 1960 for en 15 årige periode besluttet at henvise kommende forstadsdannelser til Kokkedal og Nivå samt Allerød på forstadsbåndene langs helholdvis Kystbanen og Nordbanen. Omkring de øvige større byer udlagdes derimod mindre inder- og mellemzoner, mens størstedelen af delbyudviklingsområdet udlagdes til yderzone, i hvilken byudviklingsudvalget i byudviklingsplanens gyldighedsperiode ikke ville tillade udlæg af nye sommerhusbyer, idet der for området ikke var udarbejdet en fredningsplan. ${ }^{75}$

Mens byudviklingsplanerne for den indre del af hovedstadsmetropolen og det nordlige delbyudviklingsområde således her opsugede hovedparten de eksisterende sommerhusbyer $\mathrm{i}$ forstadsdannelsen, og inddæmmede mulighederne for udvidelse af tilbageværende sommerhusbyer eller udlæg af nye, blev det først senere, at byudviklingsplanlægningen i fuldt omfang nåede ud til metropolens yderste dele. I lyset af Principskitsen og Første Etapeplanen fra starten af 60 og efterhånden som den byvækst, som hovedstadsmetropolen gerererede, begyndte at brede sig dybere ind i Frederiksborg og Roskilde amtskommuners, udvidedes de eksisterende byudviklingsområder omkring købstæderne i købstadsringen. Allerede 1960 havde Boligministeriet, som udgjorde det departementale by- og egnsplanlæggende organ, gjort sig overvejelse om udlæggelse af nye byudviklingsområder i de yderste dele af Nordsjælland for, som det udtryktes i et internt notat "at få hold på sommerhusbyggeriet", men afventede foreløbig fremkomsten af en fredningsplan for Frederiksborg Amtskommune, jf. nedenfor.

Da de tre fredningsplanudkast for denne del af hovedstadsmetropolen først forelå nogle år efter, blev der først i midten af 60 'erne oprettet to byudviklingsområder for metropolens rurale yderområder: Et for den nordlige del af Hornherred og et for Holbo Herred omfattede de dele af det nordligste Nordsjælland, som ikke indgik i Helsingørs, Hillerøds og Frederiksværks efterhånden udvidede byudviklingsområder. Men det blev først sent, at byudviklingsplanerne nåede helt ud til udkanten af disse byudviklingsområder og til dem, der med stadig større udbredelse var blevet udlagt i egnene omkring Roskilde, Frederikssund og Køge.

Den voldsomme spredning af sommerhusbyer i disse af hovedstadsmetropolens ydre dele og $\mathrm{i}$ den sydlige del af Hornsherred, der ikke var udlagt til byudviklingsområde, kom dermed længe til stå uden for den regionale inddæmning af den byspredning i det åbne land, som byudviklingsplanlægningen muliggjorde. Og da byudviklingsplanerne først i slutningen af 60 'erne nåede ud til disse dele, blev de eksisterende sommerhusbyer med udstykkede, men endnu ikke bebyggede arealer blot optaget som sommerhusbyområder i planernes yderzoner. 
Da sommerhusbyernes udstykninger her allerede havde haft et betydeligt omfang og givet disse en betydelig rummelighed, og da det samtidig var muligt for byudviklingsudvalgene at udvide sommerhusbyernes område til de uden omliggende yderzoneområder, blev egnsplanlægningen og dens tilhørende byudviklingsplanlægning reelt virkningsløs i forhold til den første efterkrigstids sommerhusbyspredning uden for den indre del af hovedstadsmetropolen. Kun gennem fredningsplanlægning og øvrige naturbevarende dispositioner, der på samme tid blev truffet, blev det til en vis grad muligt at inddæmme den planløse spredning af sommerhusbyer i metropolens ydre åbne opland. ${ }^{76}$ 


\section{Kapitel 9}

\section{Fredningsplanlægning}

Selv om der frem til begyndelsen af 50 ' erne gennemførtes betydelige fredninger, var der dog kun blevet udarbejdet egentlige fredningsplaner i form af 1940-fredningsplanen for den nordog nordvestlige del af hovedstadsmetropolen, dele af Arresø-området i Nordsjælland, Århusegnen og Fanø. I forhold til den urbanisering og de øvrige forstyrrelser i det åbne land, der i efterkrigstiden slog yderligere igennem ikke blot i den ydre del af hovedstadsmetropolen, men også ude i provinsen, blev det aktionsfelt, der var afstukket i 1937-loven og efterfølgende tillægslovgivning snart helt utilstrækkeligt. Med den høje prioritet, som friluftslivet og landets naturværdier havde i velfærdsstatens fritids- og kulturpolitik, blev naturfredningens lovmæssige rammer derfor i den første efterkrigstid udvidet af nogle omgange.

\section{Udvidede planmuligheder}

I første omgang blev det ved en ændring i fredningsloven i 1959 bestemt, at Statsministeriet og fra 1961 Kulturministeriet skulle nedsatte stedlige fredningsplanudvalg rundt om i landet. Fredningsplanudvalgene skulle udarbejde fredningsplaner og, efter Overfredningsnævnets godkendelse, administrere disse, hvilket de facto betød, at initiativet til rejsning af konkrete fredningssager $\mathrm{i}$ vid udstrækning kom til at ligge hos udvalgene. ${ }^{77}$

\section{Beføjelser}

Da ændringen i fredningsloven i 1959 særligt havde haft fokus på udvidelse af naturfredningsplanlægningens omfang og erhvervelse af arealer til bestemte rekreative og naurbeskyttende formål og i mindre grad på konsekvenserne af de hastigt voksende fjernere bydannelser og sommerhusudstykninger længere ude i hovedstadsmetropolens område og i andre store byers omgivende landskaber, og dermed bebyggelser i det åbne land udenfor både de kommende fredningsplaners områder og områder, hvor byudviklingsplanernes zonebestemmelser gjorde sig gældende, fremlagde to år efter forslag til endnu en ændring i naturfredningslovgivningen

Den endelige lov, der rummende en række andre skærpelser, men som blev noget beskåret for på ny at sikre konsensus omkring naturfredningslovgivningen, fastholdt dog lovforslaget således, at nye bygninger i det åbne land kun kunne opføres efter det stedlige fredningsplanudvalgs tilladelse. ${ }^{78}$ Herudover udvidedes samtidig de beskyttelseslinjer, der allerede gjaldt for byggeri op til kyst- og skovstrækninger til også at omfatte søer, åbne vandløb og udsigter fra visse veje. ${ }^{79}$

Bebyggelse i det åbne land var dermed for alvor sat i spil, og fik desuden en central plads i det centralstatslige Landsplanudvalg, der på samme tid, i 1961, nedsattes i forlængelse af den første egnsudviklingslov fra 1959. Landsplanudvalget skulle ikke udarbejde en egentlig landsplan, men have en løbende landsplanlæggende koordinerende funktion i forhold til både den lokalkommunale byplanlægning og den mere regionale, gennem eventuelle egnsplansplanskitser som i hovedstadsmetropolen og stedlige byudviklingsplaner, for at opnå en mere jævn fordeling af urbanisering, erhvervsudvikling og arealanvendelse i landet som helhed.

I de første år blev arbejdet noget ufokuseret som følge af forskellige faglige tilgange i Landsplanudvalget, men der opnåedes enighed om at tegne nogle overordnede planlinjer for landets fysiske udvikling. Som følge af den første efterkrigstids massive urbanisering ikke blot $\mathrm{i}$ hovedstadsmetropolen og store, mellemstore og små byer, men også i landsbyer og landdistrikter og $\mathrm{i}$ form af stadig mere udbredte sommerhusbyer, sporedes landsplanarbejdet, ligesom Egnsplanudvalget i $30^{\prime}$ erne, ind på en beskyttelse af det åbne land. 80 


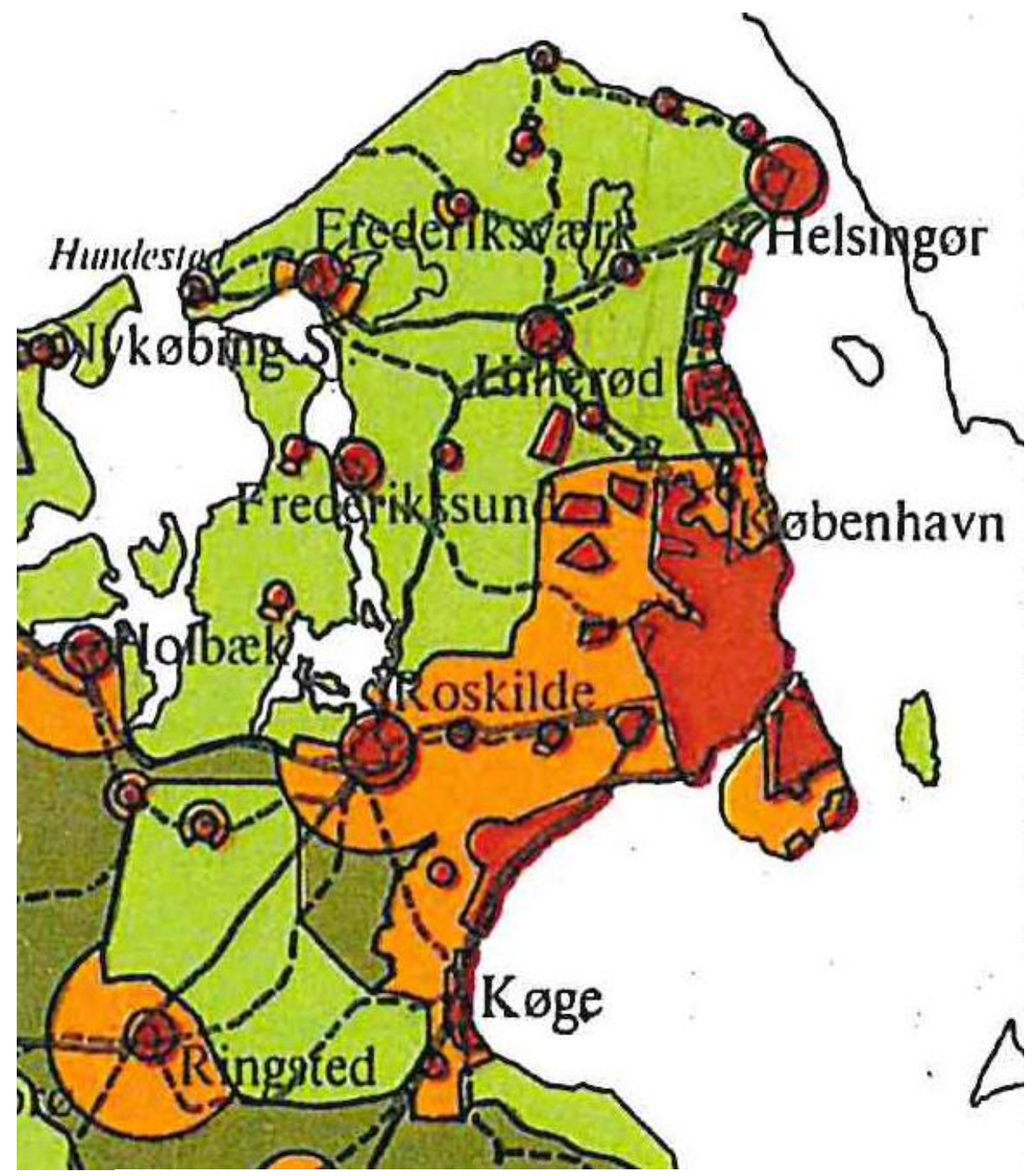

ZONE 1: By- og industriudviklingsområder

ZONE 2: Interesseområder for by- og industriudvikling

ZONE 3: Interesseområder for sommerhusbebyggelse og fredning

ZONE 4: Rene landbrugsområder

Landsplanudvalgets zoneplan, 1962 (Landsplanudvalget, august 1962)

\section{Retningslinjer}

I 1962 fremlagde Landsplanudvalget således en zoneplan, der opdelte landet i fire zoner. 1962-zoneplanen blev aldrig politisk konfirmeret, men gav på fredningsplanområdet et betydeligt afsæt for den videre fredningsplanlægning bl.a. i hovedstadsmetropolen. Her opererede zoneplanen, helt i overensstemmelse med Principskitsen, med et by- og industriudviklingsomrǻde og et interesseområde for samme omfattende hele Københavns Amtskommune, den sydøstligste del Frederiksborg Amtskommune og et meget stort og sammenhængende område trækkende sig fra den nordlige del af forstadsbåndet langs Vestbanen og til Køge Bugt med udløbere vest for Roskilde og syd for Køge. Ud over mindre rene landbrugsområder og tilsvarende mindre by- og industriudviklingsområder med tilhørende interesseområder omkring købstadsringens købstæder og større stationsbyer, udlagdes hovedparten af hovedstadsmetropolens yderområde til vidstrakte interesseområder for sommerhusbebyggelse og fredning.

1962-zoneplanen redegjorde ikke nærmere for de regionale udlæg af de vidstrakte interesseområder for sommerhusbebyggelse og fredning, men fandt at disse, omfattende 43 
procent af landets samlede areal, ud over den overvejende landbrugsdrift ville have et tilstrækkeligt omfang til at sikre både værdifulde naturområder, almene rekreative områder og meget omfattende sommerhusbydanelser, som planen forudsatte lokaliseret til kystnære områder og andre attraktive natur- og landskabsområder. Præget af tidens vækstoptimisme anslog 1962-zoneplanen, at der i de følgende årtier ville blive opført op mod en mio. sommerhuse, da det forventedes, at et sted mellem en fjerdelen og en tredjedel, mod samtidens tyvendedel, af landets familier ville fă mulighed for at erhverve et sommerhus. Forudsætningen for at kunne forene et så eksorbitant højt antal sommerhuse med de almene interesser i at sikre højklassede natur- og landsværdier og bred adgang til disse, var ifølge 1962-zonplanen blot et spørgsmål om en tilstrækkelig nøje lokal og regional planlægning.

Planen opfordrede da også til, at kommuner, byudviklingsudvalg og i særlig grad fredningsplanudvalg sporede planarbejdet i retning af de meget løselige retningslinjer, som zoneplanen omfattede. Af hensyn til befolkningens almene rekreative interesser og en hensigtsmæssig placering og udformning af fremtidige sommerhusbyer, lagdes der vægt på, at der i første omgang anlagdes en regional tilgang, således at fredningsplanudvalgene i samarbejde med kommunerne og regionale planorganer, byudviklingsudvalg og $\mathrm{i}$ hovedstadsmetropolen tillige Egnsplanssekretariatet og Byplannævnets Hovedstadsafdeling, skulle forcere arbejdet med udpegning af fremtidige sommerhusbyer for at hindre et pres på eksisterende sommerhusbyer og en planløs dannelse af nye, som de stedlige lokalkommunale beføjelser ikke i tilstrækkelig grad kunne forhindre. Sideløbende skulle fredningsplanudvalgene tillige gennemføre en udpegning af almene rekreative områder, mens den mere detaljerede lokale planlægning skulle overlades til de stedlige kommuner ud fra de rammer, der var angivet i byplanloven og landsbyggeloven; se nedenfor.

I tråd med denne opfordring udarbejde Kulturministeriet, som i 61 havde overtaget naturfredningsområdet fra Stadsministeriet, året efter en landsomfattende rammeplan, der på grundlag af 1962-zonenplanen udstak retningslinjer for det nærmere regionale fredningsplanarbejde. Retningslinjer, der i lighed med zoneplanen, tydeligvis afspejlede modsætningen mellem de individuelle fritids- og friluftsinteresser, der knyttede sig til de hastligt voksende sommerhusbyer, i ofte attraktive kyst- og landskabsområder af høj fredningsmæssig værdi, og de brede befolkningslags rekreative friluftsaktiviteter, som velfærdsstatens kultur- og fritidspolitik søgte at skabe udvidede rammebetingelse for. I dette spændingsfelt lagde Kulturministeriet op til en landsdækkende koncentrisk zonering af det åbne land baseret på en optrapning af fredningsinteresserne udgående fra byområder, 1962zoneplanens by- og industriudviklingsområder og interesseområder for samme, over almindelige ubebyggede yderzoneområder og sommerhusbyområder til det som betegnedes som naturparker.

Efter et almindeligt yderzoneområde uden om byområderne skulle dermed følge sommerhusbyområder som en art byudviklingsområde, der dannede overgang til de centrale fredningsområder. Kulturministeriet fandt i den forbindelse, at der omkring de eksisterende sommerhusbyer vil være mulighed for en noget større udbredelse, mens udlæg af nye sommerhusbyer ville komme i konflikt med de almene samfundsmæssige fredningsinteresser. For ministeriet var udgangspunktet, at sommerhusbeboeren skulle kunne opnå en individuel nydelse af siden egen grund, men at denne ikke måtte ske på bekostning af herlighedsværdier af offentlige interesse, hvortil der skulle være nem adgang for offentligheden. I naturparkerne skulle i udkanten af eller integreret med såkaldte centrale fredningsområder udlægges områder af landskabelig betydning for hele befolkningens såvel æstetiske oplevelse som fysiske rekreation, mens de centrale fredningsområder skulle omfatte: Dels områder af folkepædagogisk betydning for hele befolkningens forståelse af landskabets indhold og udvikling. Dels landets forskellige landsskabstyper- og fænomener af betydning for den naturvidenskabelige og kulturhistoriske forskning i og formidling af det danske landskabs udvikling og karakter. ${ }^{81}$ 


\section{Fredningsplanudvalgets planarbejde}

Med Kulturministeriets rammeplan var pejlemærkerne også lagt for de to fredningsplanudvalg for hovedstadsmetropolen, der i første omgang var oprettet efter ændringen i naturfredningsloven i 1959. Et for Københavns Amtskommune og et fælles for Frederiksborg og Roskilde amtskommuner, der dog i 63 sammenlagdes til et fælles fredningsplanudvalg for hele metropolområdet, som bebyggelsesmæssigt og dermed også i naturfredningsmæssig og rekreativ henseende allerede på dette tidspunkt opfattedes som en enhed, hvor der måtte træffes samlede regionale dispositioner. Fredningsplanudvalget overtog administrationen og fredningssagsrejsningen $\mathrm{i}$ forhold til fredningsplanen fra 1940 og videreudviklingen af denne. Herudover skulle udvalget ud fra Den grønne Betænknings øvrige frednings- og arealerhvervelsesforslag og en kortlægning af de fredningsmæssige værdier længere ude i hovedstadsmetropolens område udarbejde fredningsplaner og efterfølgende tage stilling til rejsning af fredningssager.

\section{Fredningsplanlægning}

Ud over at udvide 1940-fredninsgplanen med de områder på hovedstadsmetropolens Vest- og Nordvestegn, der indgik i Den grønne betænkning, og med nye områder, som ønskedes fredningsplansbelagt af Søllerød, Birkerød og Farum kommuner for at sikre disses karakter af velhavernaturforstæder, og som tillige var indarbejdet indarbejdes i metropolens byudviklingsplaner, kunne fredningsplanudvalget gennem kortlægning op gennem 60 'erne længere ude i hovedstadsmetropolens åbne land pege på en række mulige fredningsområder, hvoraf nogle kom til at indgå i konkrete godkendte fredningsplaner, mens andre blev omfattet af fredningsplanforslag.

\section{Kattegatkysten}

For at hindre, at sommerhusbyområder afspærrede yderligere dele af Kattegatkysten og trængte for langt ind i baglandet, og for at sikre både endnu mulige adgangsveje for den brede offentlighed til kysten, det store baglands betydelige landskabelige og kulturhistoriske værdier og rekreativ adgang til og anvendelse af disse, gennemførtes, på grundlag af en række mindre fredninger tilvejebragt fra $20^{\prime}$ erne og op til slutningen af 50 'erne, med dette sigte en fredningsplan, der omfattede hele kystlinjen og et bredt bælte ind i det bagved liggende landområde. Et område, der fra kysten rakte ned til linjen mellem sydsiden af Arresø og Esrum Sø.

Fredningsplanen udmøntedes efterfølgende i et meget stort antal større eller mindre fredninger og arealerhvervelser i det nordligste Nordsjælland (tabel III.47). Ved selve kystlinjen omfattede fredningerne større eller mindre endnu ikke bebyggede områder eller grønne kilearealer af forskellige bredde, der sikrede adgang til i strandene i form af bælter fra de stedlige strandveje eller gennemgående stier eller $\mathrm{i}$ bedste fald ved brede bånd løbende til kysten længere inde fra baglandet. Bånd, der samtidig brød kæden af sammenhængende sommerhusbyer mellem Vejby Strand og Rågeleje, Tinkerup Strand og Gilleleje, Nakkehoved og Munkerup, Dronningmølle og Villingebæk samt Ålsgårde-Hellebæk. Hertil føjede sig fredninger, som hindrede, at Kattegatkystens sommerhusbyer dels smeltede helt sammen inde i landet, som f.eks. sommerhusbyen Præstelodden med kirkesognelandsbyen Melby og sommerhusbyen Liseleje dels bredte sig yderlige ind i baglandet, som f.eks. syd for sommerhusbyerne Asserbo, Tibirke Bakker, Tibirke og Rågeleje. ${ }^{82}$

For at fremme til sommerhuse mere arealintensive fritidsbosætning for bredere samfundslag blev der gennem fredningsplanen, tidligere eller senere fredninger og med fredningsplanudvalget medvirken tilvejebragt ganske betydelige arealer til dette formål. I første omgang til arbejderbevægelsens første feriecenter Gilbjerg Huse fra 1942, der gennem 60 'erne kunne udvide antallet af feriehytter til 62. Efterfulgt af sammes Helsingør Ferieby opstået på offentligt erhvervede arealer i årene 1958-1964 i det højliggende skovområde ud til Kattegatkysten. ${ }^{83}$ 
Med privatbilismens stadig større udbredelse på tilsvarende måde offentlige arealer til et større antal campingpladser. I tilknytning til plantager campingpladserne Vejby Strand fra 1962 og Skibstrup og Hornbæk året efter og i de grønne kiler i årene 1956-1963 campingpladserne Nakkehoved, Dronningmølle og Răgeleje. I de fleste tilfælde udlejet af det offentlige til den almennyttige organisation Dansk Lejrsport, senere Dansk Camping Union, eller til enkelte privat oprettede, bl.a. Bokildegård Camping fra 1963 syd for Liseleje

Tabel III.47. Fredninger og arealerhvervelser, nordlige Nordsjælland, 1925-

\begin{tabular}{|c|c|c|c|c|}
\hline \multirow[t]{2}{*}{ Til sikring af: } & \multicolumn{4}{|l|}{ Lokalitet } \\
\hline & 1925- & $1960-1978$ & 1978- & \\
\hline Kyststrækninger & $\begin{array}{ll}\text { - } & \text { Fire lokaliteter i } \\
& \text { Hundested } \\
\text { - } & \text { Kikhavn } \\
\text { - } & \text { Melby Over-drev } \\
\text { - } & \text { Tisvilde Skrænt, } \\
& \text { Tisvildeleje } \\
\text { - } & \text { Helnekilden, } \\
& \text { Tisvilde-leje } \\
\text { - } & \text { Vejby Kyst, Vejby } \\
& \text { Strand } \\
\text { - } & \text { Rågeleje } \\
& \text { Skrænter, } \\
& \text { Rågeleje }{ }^{00} \\
\text { - } & \text { Gilleleje } \\
& \text { Øststrand } \\
91\end{array}$ & $\begin{array}{ll}\text { - } & \text { Hald Strand }^{92} \\
\text { - } & \text { Heatherhill, Vejby } \\
& \text { Strand } \\
\text { - } & \text { Gilberg/Gilbjerghoved }{ }^{94} \\
\text { - } & \text { Gilleleje Veststrand }\end{array}$ & & Hald Strand ${ }^{96}$ \\
\hline $\begin{array}{l}\text { Kystforbindende } \\
\text { kiler }\end{array}$ & $\begin{array}{ll}\text { - } & \text { Røde Kilde, Vejby } \\
& \text { Strand }{ }^{97} \\
\text { - } & \text { Hellebækgo̊rd, } \\
& \text { Hellebæk }\end{array}$ & $\begin{array}{ll}\text { - } & \text { To lokaliteter ved Kik- } \\
& \text { havn }{ }^{98} \\
\text { - } & \text { Hald Strand } \\
\text { - } & \text { Heatherhill, Vejby } \\
& \text { Strand }{ }^{100} \\
\text { - } & \text { Smidstrup Strand }{ }^{101} \\
\text { - } & \text { Gilberg/Gilbjerghoved }{ }^{102} \\
\text { - } & \text { Seks mindre kiler i } \\
& \text { sommerhusbyen vest } \\
& \text { for Gilleleje }{ }^{103} \\
\text { - } & \text { Nakkehovedkilen, } \\
& \text { Nakkehoved } \\
\text { - } & \text { Hellebækgaard, Helle- } \\
& \text { brk }^{105}\end{array}$ & & $\begin{array}{l}\text { Udsholt Strand }{ }^{106} \\
\text { Nakkehovedkilen, } \text { Nakkehoved }{ }^{107} \\
\text { Rusland/Pandehave } \\
\AA, \\
\text { Dronningmølle }^{108}\end{array}$ \\
\hline $\begin{array}{l}\text { Landskaber og sø } \\
\text { områder mod } \\
\text { sommer- } \\
\text { husbyspredning }\end{array}$ & $\begin{array}{ll}\text { - } & \text { Tibirke Bakker }{ }^{109} \\
\text { - } & \text { Arrenæs, Arres } \emptyset^{110}\end{array}$ & $\begin{array}{ll} & \text { Melby Gravhøje }{ }^{111} \\
\text { - } & \text { Brødemose, Asserbo }{ }^{112} \\
\text { - } & \text { Tibirke Syd } \\
\text { - } & \text { Arrenæs, Arres } \emptyset^{114} \\
\text { - } & \text { Annisse strand. } \\
& \text { Arres } \emptyset^{115} \\
\text { - } & \text { Ramløse Søkrog, } \\
& \text { Arres } \emptyset^{116} \\
\text { - } & \text { Maglehøje, Rågeleje }{ }^{117}\end{array}$ & • & $\begin{array}{l}\text { Arrenakke Bakker, } \\
\text { Asserbo }^{118} \\
\text { Ryenge }^{119} \\
\text { Lille Lyngby Mose }\end{array}$ \\
\hline $\begin{array}{l}\text { Sammenhængende } \\
\text { skov- og søområder }\end{array}$ & $\begin{array}{l}\text { - Strødam Reservat, } \\
\text { ved Gribskov }{ }^{120} \\
\text { Ved den nordøst- } \\
\text { lige del af Esrum } \\
\text { Sø } \varnothing^{121}\end{array}$ & 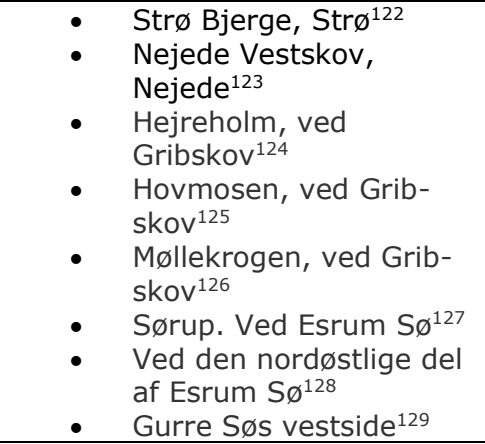 & $\begin{array}{l}\bullet \\
\bullet \\
\bullet\end{array}$ & $\begin{array}{l}\text { Ved Teglstrup } \\
\text { Hegn }^{130} \\
\text { Rørtang, ved Nyrup } \\
\text { Hegn }{ }^{131} \\
\text { Kelleris Kystkilde, } \\
\text { ved Espergærde } 132\end{array}$ \\
\hline Udsigter m.m. & $\begin{array}{ll} & \text { Hundested }{ }^{133} \\
- & \text { Kovang, ved } \\
& \text { Esrum Sø } \varnothing^{134} \\
\end{array}$ & - $\quad$ Gilberg/Gilbjerghoved ${ }^{135}$ & & \\
\hline
\end{tabular}




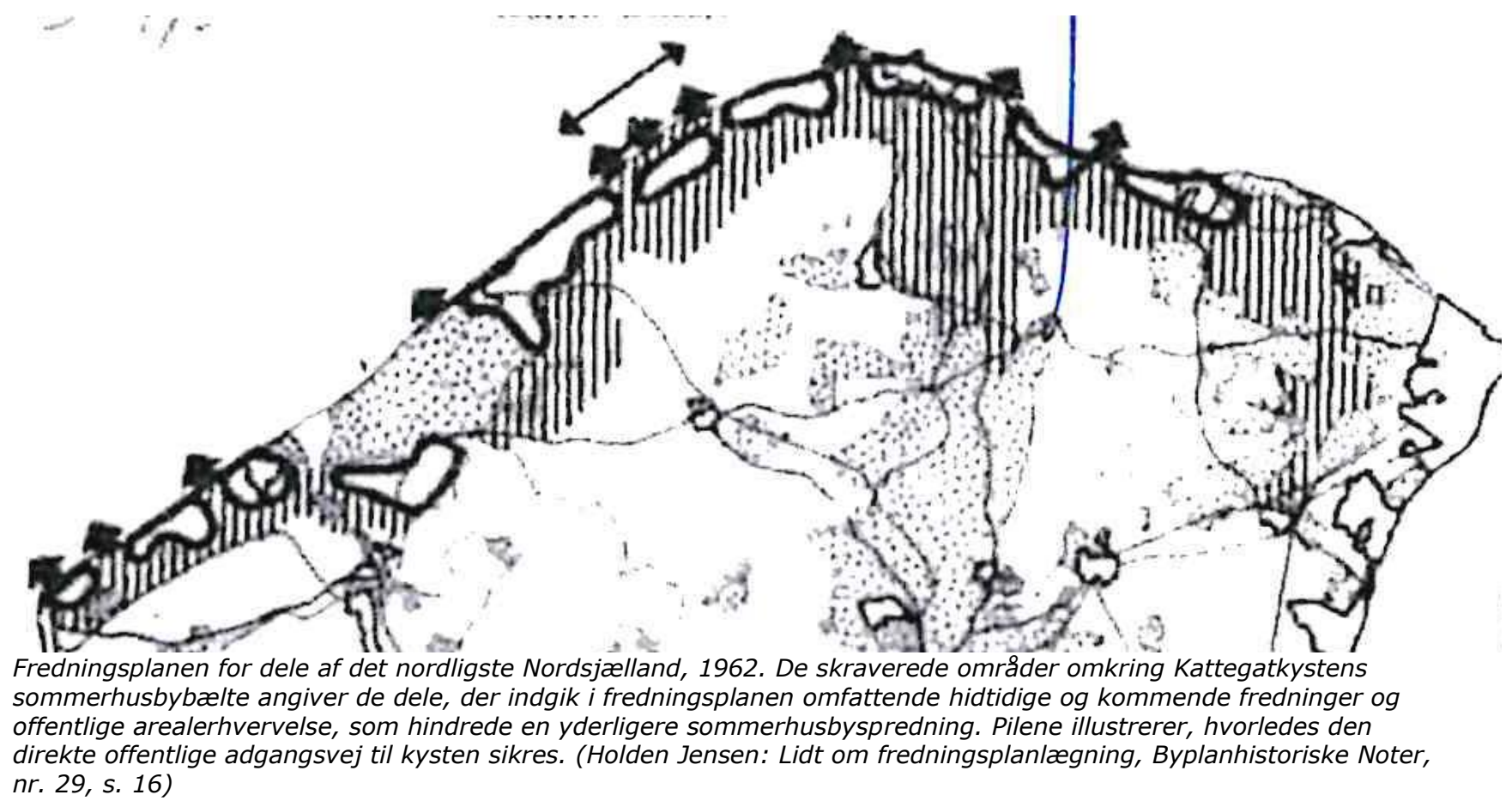

Længere inde i landet tilsigtede fredningerne og arealerhvervelserne dels en inddæmning af sommerhusbyspredningen særligt i landskaberne omkring Arres $\emptyset$ og Esrum Sø, dels en sikring af større landsskabsområder, der tillagdes særlig natur- og kulturhistorisk og almenrekreativ værdi, ved etablering af mere sammenhængende og forbindende rekreativt tilgængelige højklassede natur- og kulturhistorisk landskabsområder mellem Gribskov og det nordøstligste Nordsjællands søer og øvrige skove. Samme fredningsprincip som tidligere havde indgået i 1940-fredningsplanen for hovedstadsmetropolens Nord- og Nordvestegne, og som gik igen ved efterkrigstidens store fredninger i det halvcirkelformede område mellem roden af Hornsherred og det nordlige Stevns, se nedenfor.

Da fredningerne i det nordligste Nordsjælland ikke blot var af interesse for selve hovedstaden, men hele hovedstadsmetropolen dækkede staten mellem halvdelen og 90 procent af erstatningsomkostninger, mens Frederiksborg Amtskommune ydede de resterende midler, og hovedstadskommunerne friholdtes på nær fredningen af Heatherhill. De dele af fredningsplanen, der ikke gennemførtes i den første efterkrigstid og frem til fredningsplanudvalgenes nedlæggelse i 1978, kom siden til at indgå i Hovedstadsrådets sektor- og regionsplanlægning, der med yderligere udvidelse med områder af rekreativ, biologisk, geologisk og kulturhistorisk værdi dannede grundlag for yderligere fredninger og arealerhvervelser i den resterende del af den sidste efterkrigstid og overvejende op gennem 90 'ene; jf. Del IV, Kapitel 4. ${ }^{136}$

\section{Hornsherred og Roskilde Fjord østside}

For Hornsherred og kystbæltet langs Roskilde Fjord østside udarbejde hovedstadsmetropolens fredningsplanudvalg tillige i den første del af $60^{\prime}$ erne et fredningsplanforslag. Målet var i disse endnu mindre urbaniserede dele af metropolen med udgangspunkt i det mindre antal fredninger, der var gennemført før 1960, at bevare forsat eksisterende højklassede kyststrækninger og bagved liggende landskabsområder og åbne disse for den brede metropolbefolkningens udflugter og rekreative friluftsliv. En af de afgørende forudsætninger herfor var at begrænse nye sommerhusdannelser, anden bebyggelse og andre foranstaltninger, der kunne ændre det naturlige miljø, ved bl.a. at fastlægge eksisterende og evt. nye sommerhusbyer som afsluttede og afgrænsede enheder. Ganske vist beliggende nær naturattraktioner, men samtidig indbyrdes adskilt af så store og ubrudte landskabsstrøg som 
muligt, hvorved de karakteristiske sammenhængende og kystafskærende sommerhusbybælter, som kendtes fra Kattegatkysten og Køge Bugt op til omkring midten af det 20. århundrede, blev forhindret.

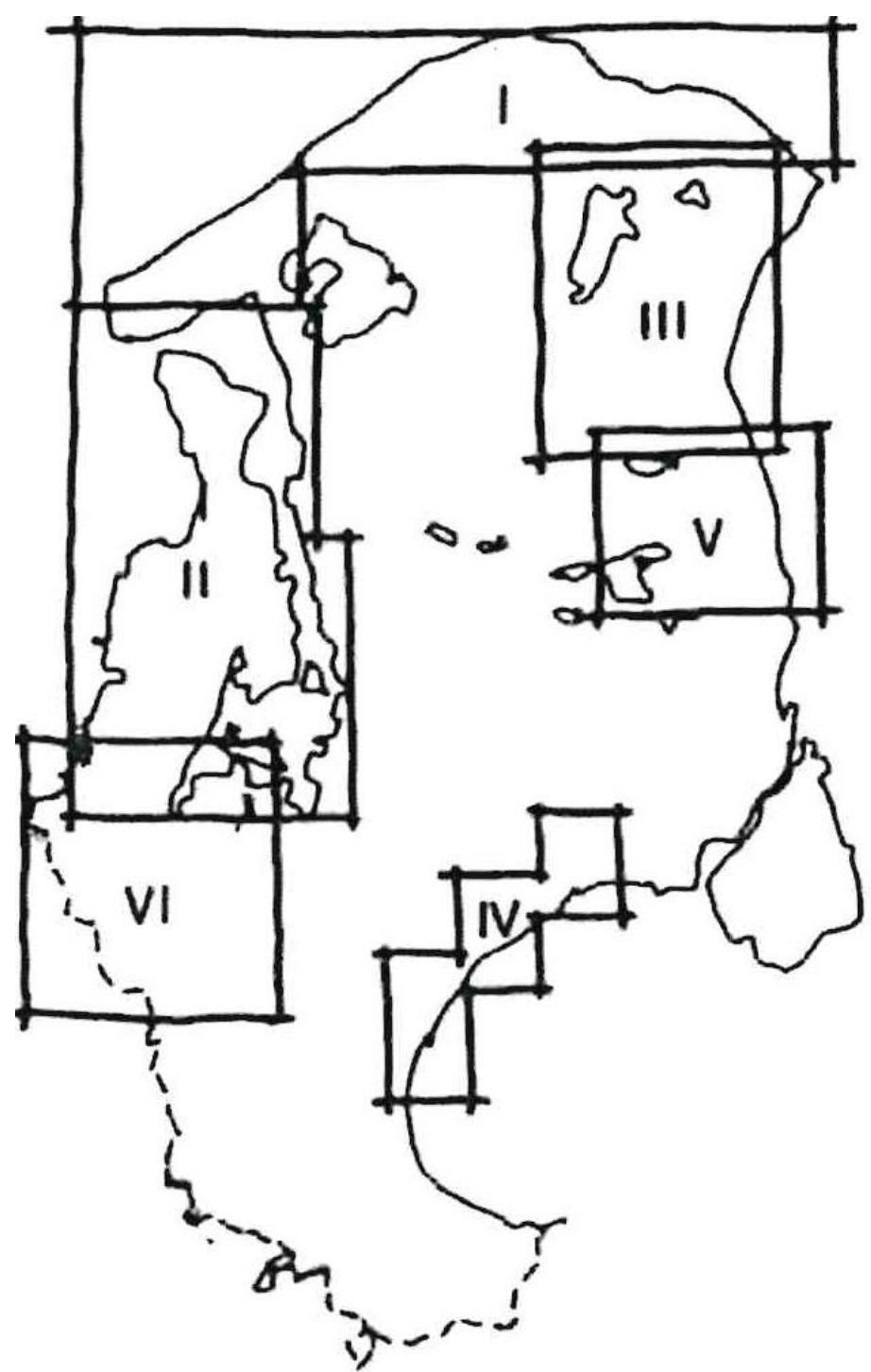

Fredningsplaner og fredningsplanforslag, 1960-1968 (Holden Jensen: Lidt om fredningsplanlægning, Byplanhistoriske Noter, nr. 29, s. 16)

På dette grundlag tilstræbte fredningsplanforslaget at sikre en række nærmere definerede rekreative områder. Fredningsplanforslaget blev ikke endelig godkendt af overfredningsnævnet, og opnåede således ikke retsvirkning. Til gengæld fik fredningsplanforslaget efterfølgende afgørende betydning for kommunerens administration af bygnings- og byplanlovgivningen og byudviklingsudvalgenes forvaltning af de enkelte byudviklingsområders inder-, mellem- og yderzone og udlæg af dele af yderzonerne til sommerhusbyer, ligesom det kom til at danne grundlag for efterfølgende arealerhvervelser og fredninger i medfør af naturfredningslovens beføjelser.

Gennem disse dispositioner og da de dele af fredningsplansforslaget, der ikke gennemførtes frem til fredningsplanudvalget nedlæggelse i 1978, overførtes til Hovedstadsrådets sektor- og regionsplanlægning, som endda udvidedes med yderligere områder af natur- og kulturhistorisk værdi, lykkedes det at gennemføre principperne i forslaget i den resterende del af efterkrigstiden og op gennem 90 'ene; jf. Del IV, Kapitel 4. 
Mest vellykket i Hornsherred, hvor det på trods af den korte afstand mellem sommerhusbyerne Ejby Strand og Kyndeløse Sydmark og mellem Over Dråby Strand og Dalby Huse, lykkedes at skabe grundelaget for dannelsen af samlede, men afgrænsede og fra hinanden af betydelige åbne kyststrækninger adskilte sommerhusbyer, hvorved sammenhænde sommerhusbybælter blev undgået. Hertil kom, at der i forbindelse med sommerhusbyerne med arealfredningerne og- erhvervelserne tilvejebragtes betydelige friarealer, som både kompenserede for disses ofte fătallige og begrænsede fællesarealer, og blev åbnet for den brede offentlighed.

Således overtog Gerlev-Dråby Sognekommune efter en fredning i 1962 et ganske betydeligt område ved i den nordligste del af sommerhusbyen Kulhuse på Hornsherreds nordlige spids ud til Roskilde Fjord og Isefjorden og de to fjordes sammenløb. Her udlagde kommunen et offentligt rekreativt områder med strandadgang, parkeringspladser, offentlige toiletter, iskiosk samt en campingplads, der indrettedes og bebyggedes med fælleshus af denne, og efterfølgende blev drevet af Dansk Camping Union. Således helt som ved tilsvarende dispositioner for at etablere en til sommerhuset alternativ og arealintensiv fritidsbosætning for mindre bemidlede befolkningslag. ${ }^{137}$

Mens det i 1882 etablerede og siden udvidede 1.531 ha store $ø$ velses- og skydeterræn under Hærens Jægerspris Lejren hindrede enhver form for bebyggelse syd for Kulhuse i nord og ned til landevejs- og slotbyen Jægerspris, i området mellem Isefjordens kyst i vest og frem til det vidtstrakte skovområde mod øst, kom hovedparten af fredningsplanforslaget for Hornsherreddelen og efterfølgende fredninger og arealerhvervelser til at omfatte halvøens syd for liggende del. ${ }^{138}$

På kystbæltet ud til Isefjorden sikredes således ved fredninger fra 1938, 1958 og 1972 Landerslev Strand og det kuperede landskab i baglandet mellem sommerhusbyerne Over Dråby Strand og Dalby Hus, mens det langstrakte kystområde og det tilsvarende landskab mange gravhøje i baglandet fra Sømer Skov, syd for Kyndbyværket, og ned til og med Hammer-halvøen, nord for sommerhusbyen Vellerup Sommerby, på den midterste del af kystbæltet bevaredes ved storstillede fredninger i årene 1963-1968. ${ }^{139}$ På den sydlige del af Hornsherreds kystbælte ved Isefjorden frededes i 1952 og senest i 1996 kyststrækningerne med vide udsigter over fjorden nord for, ud for og syd for sommerhusbyen Kyndeløse Sydmark i retning mod henholdsvis Ejby Strand sommerhusby og Kyndeløse Nordmark sommehusby og den syd for liggende Ejby Adal i dens forløb ind i landet. For at sikre bevaring af de naturmæssigt højklassede kyst- og landskabsområde op til og bag ved Bramsnæs Vig og Tempelkrog i bunden af Isefjorden og en sammenhængende overgang til de syd for liggende meget omfattede skovrige område, frededes ved roden af Hornsherred i 1958 og efterfølgende i perioden 1964-1975 meget betydelige del af Ryegård Gods arealer. ${ }^{140}$

Ved den østlige del af Hornsherreds rod sikredes med udgangspunkt i en mindre fredning $\mathrm{i}$ 1947 og omfattende fredninger i 1962-1963 hele kysttrækningen, med bagland, langs Lejre Vigs vestside fra kirkesognelandsbyen Lyndby i nord til Lindenborg i syd samt et meget betydeligt område syd herfor og på vigens østside kyststrækningen udfor den nordlige del af sommerhusbyen Lindenborg og øst for denne områder langs Gevninge $\AA$. Herved bevaredes udsigten over vigen, højklassede kyst- og landsskabstrækninger, en sammenhængende overgang til de ovenfornævnte syd for liggende meget omfattede skovrige områder. ${ }^{141}$ Længere oppe ad Hornsherreds kysbælte ud til Roskilde Fjord bevaredes med en mindre fredning i 1948 og efterfølgende større fredninger i 1969 Sels $\varnothing$, tilstødende naturmæssige og kulturhistorisk højklassede landskaber og kyststrækningen ved Roskilde Fjords Bredvig. ${ }^{142}$

Øst for frededes i 1967 Østby Flak og Hammerdybet. Et langstrakt kystnært område med et betydeligt bagland syd for den senere sommehusby Hyllingeris mod nord og til syd for forbindelseslejet til Eskilds $\varnothing$ mod syd. ${ }^{143}$ For at undgå yderligere bortgravning af sand og grus i Skuldelev Ås og dermed ødelæggelser af dennes betydelige landskabelige værdi, var et bælte langs Roskilde Fjord øst for Skuldelev kirkesognelandsby og åsens videre forløb ind i landet 
blevet fredet i 1951. ${ }^{144}$ På samme tidspunkt var Kignæs Havn og omgivende engarealer fredet for at bevare udsigten over Roskilde Fjord i landevej- og slotsbyen Jægerspris. ${ }^{145}$ Nord for sikredes med udgangspunkt i en i 1972 rejst fredningssag i 1988 den næsten $10 \mathrm{~km}$ lange kyststrækning og en smal del af det til Roskilde Fjord kystnære område ved og langs Nordskoven på Hornsherreds nordlige del. ${ }^{146}$

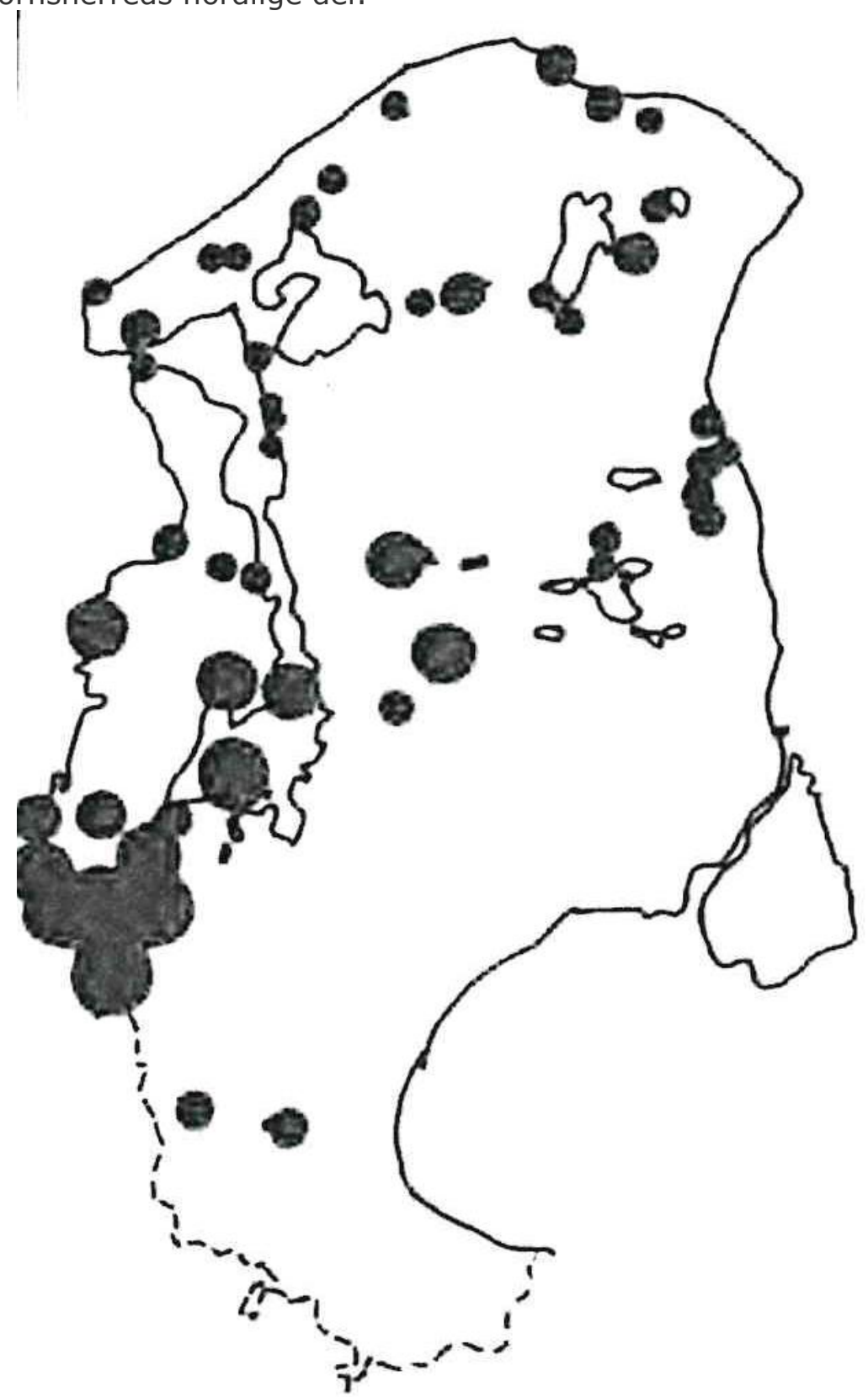

Fredninger, 1959-1975. (Holden Jensen: Lidt om fredningsplanlægning, Byplanhistoriske Noter, nr. 29, s. 11)

På den modsatte side af Roskilde Fjord frededes 1963 et større areal mellem sommerhusbyerne St. Karslminde og Hannehoved, Hågendrup Kyst, på Halsnæs sydside, mellem landevejen Frederiksværk-Hundested og fjordkysten, for her at bevare udsigten til denne, mens det åbne område med kystskrænt neden for den senere sommerhusby Hannehoved allerede var blevet fredet. ${ }^{147}$

Syd for Frederiksværk sikredes gennem en række successive fredninger i hele perioden 19191976 området "Hvide Klint", mellem købstaden og sommerhusbyen Lille Kregme, som et alment rekreativt område, hvori allerede en i 1930 en selvejende feriekoloni etableredes, og 
langt senere Husligt Arbejderforbund i 1971 opførte en koloni af ferieboliger. Et andet i forhold til sommerhuset alternativ for fritidsbosætning, som velfærdsstaten gennem sine arealdispositioner forsøgte at fremme i den første efterkrigstid. Mellem sommerhusbyerne Lille Kregme Strand og Kregme Strand frededes endvidere det stærkt kuperede udsigts- og landskabsområde Grævlingehøj, mens sidstnævnte sommershusby deltes ved en frivillig fredning i 1966 af området Fuglevad og det syd for forblevne ubebyggede område på markerne til gården Kildemose. ${ }^{148}$

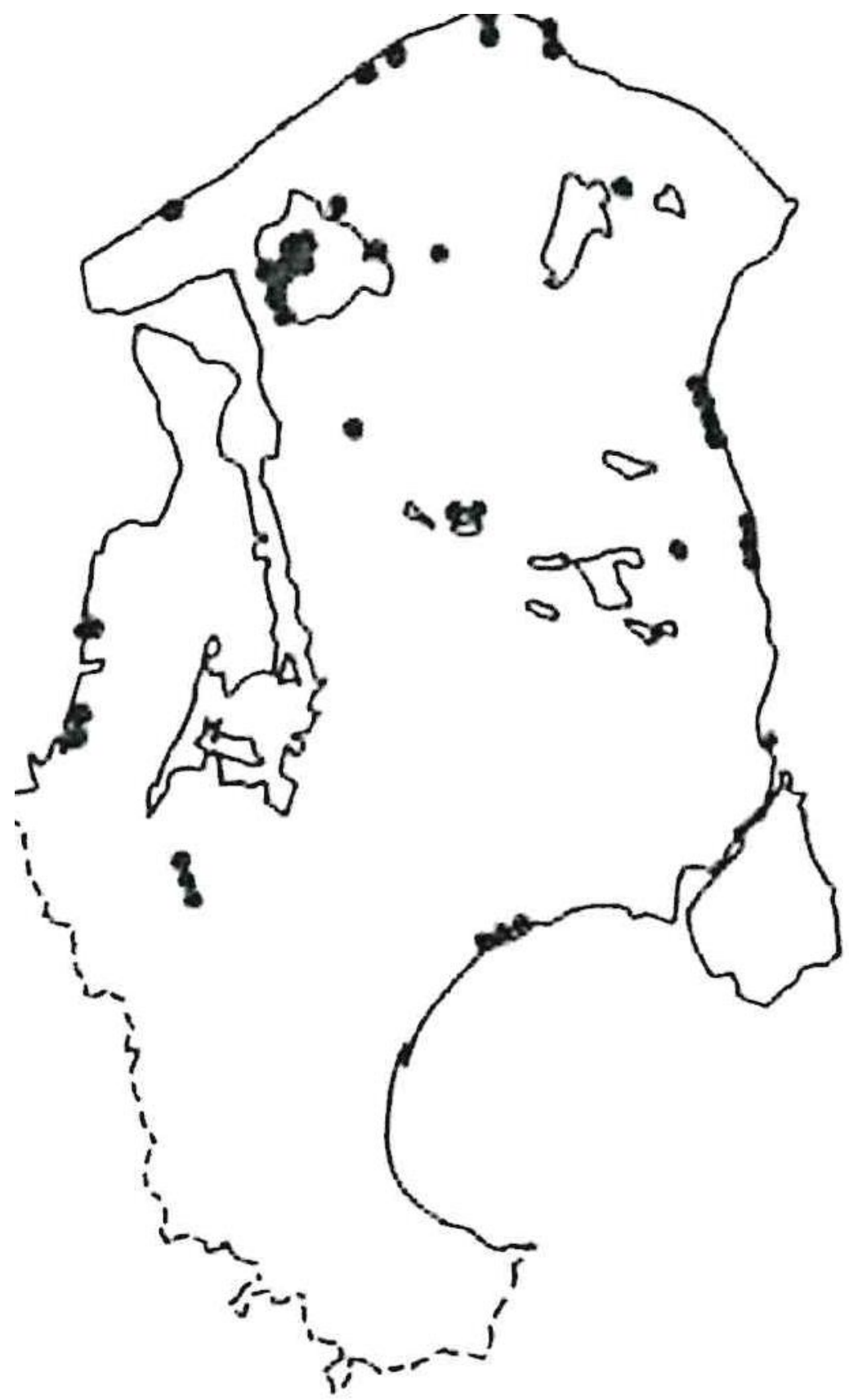

Rekreative ejendomserhvervelser, 1974 (Holden Jensen: Lidt om fredningsplanlægning, Byplanhistoriske Noter, nr. 29, s. 23).

Selv om det i modsætning til Hornsherred og ved Halsnæs sydside ikke i samme grad lykkedes at skabe grundlaget for afsluttede og afgrænsede sommerhusbyer ved Roskilde Fjords kystbælte mellem Frederiksværk og Frederikssund, og sommerhusbyerne fra Lille Kregme 
Strand i nord til Store Havelse i syd dermed mere fik karakter af et sommerhusbybælte, som kendtes fra Kattegatkysten, udmøntedes bestræbelserne i den retning i kystbæltet mellem Frederikssund og Roskilde. For at sikre de landskabelige, kulturhistoriske og biologiske værdier i det 10 km lange kystområde med bagland, Lille Rørbæk, fra den sydlige del af Frederikssund i nord til sommerhusbyen Jyllinge Normark mod syd, rejstes 1973 i den anledning en fredningssag, der friholdt området for videre bebyggelse, indtil den endelige fredning blev gennemført i 1997. ${ }^{149}$ Syd for Jylling sikrede mindre kystskovstrækninger, den tidlige fredning af Bolund i 1941 og statens arealerhvervelser langs kysten og i dennes bagland til i 1955 oprettede Atomenergi-kommissionens Forsøgsanlæg Risø, at kystbæltet ned til Roskildes yderdistrikter, Vedelev og Himmelev, forblev ubebygget. ${ }^{150}$

Samlet kom 60 'ernes fredningsplanforsalg og senere Hovedstadsrådets sektor- og regionsplanlægning til at danne grundlag for at, der op gennem efterkrigstiden og i 90 'erne i Hornsherred og i kysbæltet ved Roskilde Fjords nord- og sydside sikredes meget betydelige højklassede natur- og kulturhistoriske kyst- og landskabsområder, der samtidig blev åbnet for udflugter og et rekreativt friluftsliv for hele hovedstadsmetropolens befolkning. Dispositioner, der på nær enkelte undtagelser samtidig sikrede en sommerbydannelse kendetegnet ved afgrænsede og afsluttede spredt liggende byenheder langs områdets kyster. Til dækning af omkostningerne hertil ydede staten fra to tredjedele og op til 90 procent, mens Frederiksborg og Roskilde amtskommuner, i nogle tilfælde med bidrag fra de i disse beliggende købstads- og senere primærkommuner, tilvejebragte restbeløbet.

\section{Det sydlige skov- og landskabsbælte}

Ud over fredningsplanen og fredningsplanforslaget for de nordlige dele af hovedstadsmetropolens ydre åbne opland, udarbejdes tillige et fredningsplanforslag for skovog landskabsbæltet, der som et halvcirkelsalg fra Hornsherreds rod løb i retning mod det nordlige Stevns. Selv om dette forslag heller ikke opnåede Overfredningsnævnets godkendelse, kom det dog på samme måde som fredningsplanforslaget for Hornsherred og kystbæltet ved Roskilde Fjord til at danne grundlag for meget omfattende og sammenhængende fredninger og offentlige rekreative arealerhvervelser $i$ det store område både frem til nedlæggelsen af fredningsplanudvalget i 1978 og i den sidste del af efterkrigstiden og i 90 'erne, idet de ikke gennemførte dele af planforslaget tillige samme med andre fredningsinteresser kom til at indgå i Hovedstadsrådets sektor- og regionsplanlægning; jf. Del IV, Kapitel 4.

Som 1940-fredningsplan for hovedstadsmetropolens Nord- og Nordvestegne og den senere fredningsplan for dele af det nordlige Nordsjælland, havde fredningsplanforslaget til formål gennem fredninger og arealerhvervelser at sikre sammenhængende og forbindende rekreativt tilgængelige højklassede natur- og kulturhistoriske landskabsområder mellem områdets store skove, søer, moser og enge og som sidegevinst at hindre yderligere sommerhusbydannelser i samme område. Ud over fredninger omkring Kattinge Vig og de der liggende skove, ved Lejre Vig, Bramsnæs Vig og Tempelkrog, sikredes således meget betydelige landområder af Àstrup, Sonnerupgård og Ledreborg godser, Gammel Lejres, Særløse, Ndr. Hvalsøe og Kisserup landsbyers bymarker, Skov Hastrup Overdrev og Ramsødalen. Sydøst herfor desuden af Regnemark Mose, Valore Mose og Kimmerslev Sø med baglande og vest og syd for Køge: Køge og Vittenbjerg åse samt betydelige landområder af Gammel Lellingegård, Køgegård og Vallø godser. Ved erstatninger herfor ydedes af staten tre fjerdedele, mens Roskilde Amtskommune og dets købstadskommuner, og senere Hovedstadsrådet, tilvejebragte restbeløbet. ${ }^{151}$ 
I et forsøg på, i overensstemmelse med Principskitsen fra 1960, at koncentrere den indre del af hovedstadsmetropolens fortsatte vækst mod sydvest og dermed i højere grad at friholde den midterste del af Nordsjælland for urbaniseringens pres, lagde fredningsplanudvalget i 1963 desuden op til en skitse til en fredningsplan for hele området mellem Helsingør, Hillerød og Hørsholm. Området omfattede ikke egentlige sommerhusbyer i større omfang, men betydelige rekreative områder for den indre del af hovedstadsmetropolen. Da planen omfattede yderzonebelagte arealer og ikke specifikt de områder, der havde fredningsværdi, kunne den ikke tiltrædes af Overfredningsnævnet, men dannede alligevel grundlag for en række senere fredninger i området.

\section{Øvrige dispositioner}

Ud over fredningsplanarbejdet og de konkrete fredninger og arealerhvervelser blev det i øvrigt fredningsplanudvalget, der samarbejde med de stedlige byudviklingsvalg de facto meddelte tilladelse til udlæg af sommerhusbebyggelse i de dele af de ydre oplande, der var omfattet af en byudviklingsplan og dermed i dennes yderzoneområder. Herudover havde fredningsudvalget, som anført, ved den lille ændring i naturfredningsplanloven i 1961 fået mulighed for at dæmme op for de værste vildskud, idet nye bygninger, herunder sommerhuse, i det åbne land uden for byudviklingsplaners yderzoneområder kun kunne opføres efter det stedlige fredningsplanudvalgs tilladelse.

For at forberede udvalget på stillingtagen til sådanne tilladelse fik det fra Matrikeldirektoratet forelagt samtlige udparcelleringssager i hele hovedstadsmetropolens åbne opland. I og omkring dettes allerede udlagte sommerhusbyer gav fredningsplanudvalget dog nærmest automatisk de ønskede tilladelser, men satte sig dog i mod, hvis der her udstykkedes eller bebyggedes arealer på eller op til udsigtspunkter, eller kommende bebyggelse ville spærre udsynet fra sådanne. Særlig restriktiv var udvalget ved opførelse af et eller flere enkeltstående fritliggende sommerhusbygninger i hovedstadsmetropolens åbne land, idet disse senere ville kunne give anledning til dannelse af en egentlig sommerhusby. ${ }^{152}$ 


\section{Sommerhusbyen - en forsat regionsudfordring}

Mens dannelsen af sommerhusbyer i mellemkrigstiden gennemførtes under minimal offentlig regulering, og 1940-fredningsplanen alene inddæmmede sommerhusbyspredningen i den indre del af hovedstadsmetropolen, førte den første efterkrigstids sommerhusboom til en noget mere udbredt lokalkommunal regulering og planlægning af periodens sammehusbydannelser; jf. APPENDIX VII. Det blev dog først i 60 'erne og i de første år af det følgende tiår, hvor spredningen af sommerhusbyer allerede havde fundet og yderligere accelererede $\mathrm{i}$ hovedstadsmetropolen ydre åbne land, at denne regionale udfordring fors $\varnothing$ gtes planmæssigt inddæmmet. Da denne inddæmning blot var en udløber af en planlægning, der havde et andet primært sigte, udgjorde sommerhusbyerne i hovedstadsmetropolens åbne land i starten af 70 'erne forsat en betydelig regional udfordring.

\section{Den kritiske sommerhusbysperdning}

Som følge af at amtskommunerne ikke udnyttede de regionale planbeføjelser, der tillagdes disse med landsbyggeloven fra 1960, og egnsplanlægningen alene dæmmede op for sommerhusbyspredningen i de indre dele af hovedstadsmetropolen, blev denne regionale udfordringer, der næsten udelukkende gjorde sig gældende i metropolens ydre åbne opland, alene inddæmmet af fredningsplanmæssige dispositioner. Selv om 60'ernes fredningsplanlægningen og de samtidige konkrete fredninger og arealerhvervelse repræsenterede en betydelig rekreativ og naturbeskyttende landvinding, blev den delvise afgræsning af sommerhusbyernes videre spredning blot en positiv sidegevinst.

De fredningsplanmæssige dispositioner havde således til formål at bevare kyst- og landskaber og sikre offentlighedens adgang til disse, men havde ikke et egnsplanmæssigt sigte. Ud over sene inder-, melemme- og yderzoneudlæg i visse områder, fredede og øvrige offentligt erhvervede rekreative områder og udlæg af til sommerhuset alternative fritids- og feriebosætningsformer for de bredere befolkningslag, blev hovedstadsmetropolens ydre åbne land og dets erhvervsmæssige anvendelse, sommerhusbyer og fremvoksende pendlersatellitbyer ikke genstand for en samlet regional planlægning i den første efterkrigstid. Hverken i henseende til disse bymæssige bebyggelser regionalt planmæssigt mest rationelle lokalisering, regionale trafik-, forsynings- og spildevandsafledningslinjer til disse eller regionale retningslinjer for landskabets anvendelse til land- og skovbrug og råstofudvinding og disse erhvervs samspil med dets øvrige funktioner.

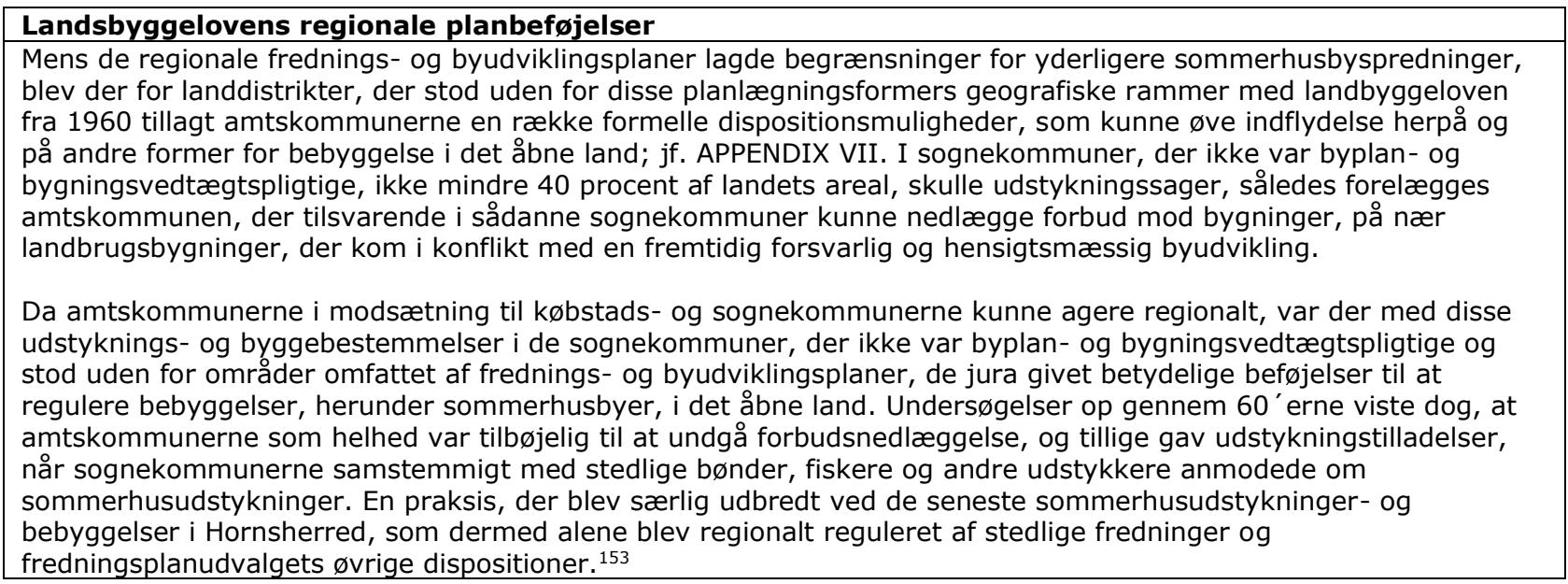

Hertil føjede sig, at Landsplanudvalget på trods af de regionale fredningsplanmæssige dispositioner ved en kortlægning allerede i 1966 kunne påpege forsatte meget store regionale 
udfordringer i forhold til sommerhusbyspredningen. Kortlægning dokumenterede således, at mulighederne for intensiv badning og rekreative friluftsophold kun var muligt over $200 \mathrm{~km}$ af den $1.700 \mathrm{~km}$ lange kyststrækning omkring Sjælland og Møn, og at over halvdelen af disse $200 \mathrm{~km}$ var belagt med sommerhusbyer eller reserveret til udvidelse og nyudlæg af sommerhusbyer. Kortlægningen kvantificerede ikke specifik forholdene ved hovedstadsmetropolens kyststrækninger, men da dens kystlinjer, der var egnet til både badning og ophold indgik i sommerhusbybæltet ved Kattegatkysten og sommerhusbyerne på den nordvestlige del af Hornsherred, måtte situationen her have været særlig kritisk.

En chokerende konstatering, der foranledigede Landsplanudvalget til at konkludere at: "Kystområderne udgør antagelig landet vigtigste arealressourcer til fritidsformål. Ind til der foreligger samlede og koordinerede planer for disse områders anvendelse til rekreative formål, fredning, bebyggelse, trafikanlæg m.v., er det derfor nødvendigt, at yderligere sommerhusbebyggelse i endnu ubebyggede kystområder stadses". ${ }^{154}$ En konklusion, der førte til, at Landsplanudvalget kortlægningsarbejde efterfølgende kom til at omfatte hele landet, der senere mundede ud $\mathrm{i}$ et mere vidtgående planmateriale om arealanvendelsen $\mathrm{i}$ det åbne land:

Dels i en grøn zoneplan fra 1969 med udpegning af fredningsmæssige og rekreative interesseområder, der rummede mulighed for rekreative oplevelser i langt større naturområder end dem, som indgik i fredningsplanerne og fredningsplanforslagene. Dels en landsdækkende rapport om arealplanlægning fra 1974, der udover planmæssige og prioriterede pejlemærker for byudvikling, centre, industrilokalisering, trafik- og forsyningsanlæg og- linjer også udstak meget overordnede linjer for den erhvervsmæssige arealanvendelsen af det åbne land og, på basis af fredningsplanudvalgenes landskabsanalyser, særlige interesseområder af landskabelig, videnskabelig og rekreativ betydning. Interesseområder, hvor eksisterende og kommende sommerhusbyområder indgik, og som blev et afgørende grundlag for den kommende frednings- og arealanvendelsesdel i Hovedstadsrådets og amtskommunernes regionsplanlægning for det åbne land; jf. Del IV, Kapitel $6 .{ }^{155}$

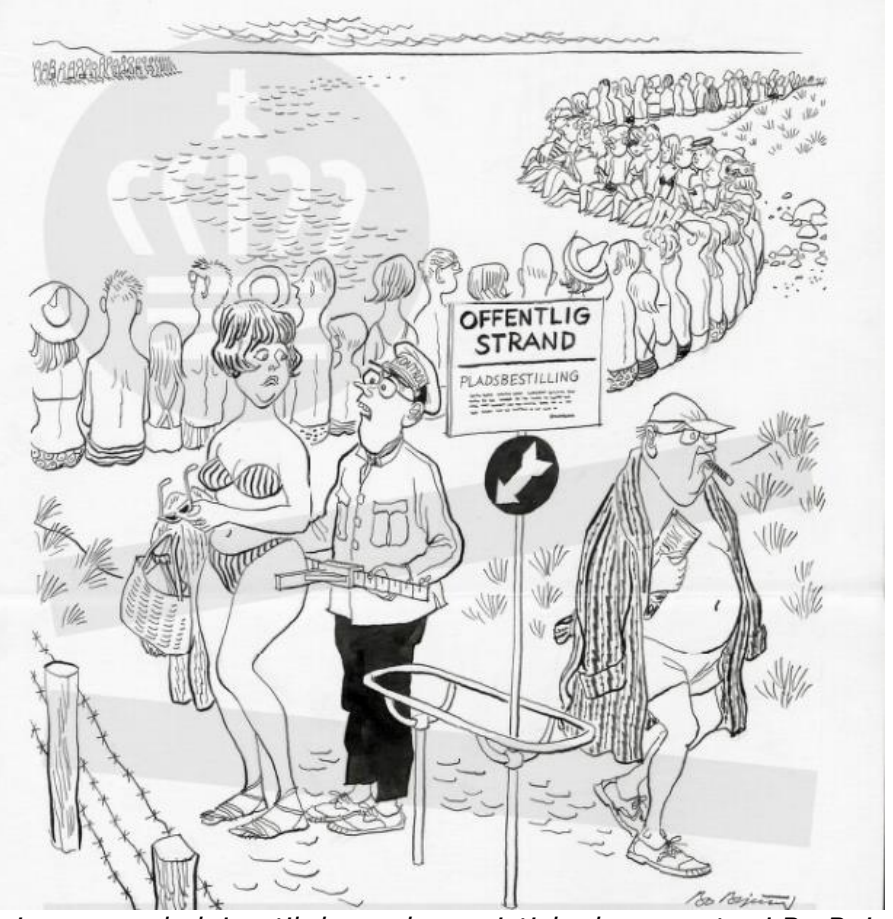

Landsplanudvalgets kortlægning gav anledning til denne humoristiske kommentar i Bo Bojesens streg i Politiken i efteråret 1966. Den uniformerede myndighedsperson siger: "Jeg må desværre bede Dem gå hjem igen: De overskrider de statistiske beregninger med 12,8 cm". Underteksten lyder: "Ifølge Landsplanudvalget er der på Sjælland-Møn kun 0,3 m strandbred til hver indbygger, hvorefter man tilråder drastiske forholdsregler". (Politiken, 28.10.1966) 


\section{Et regionalt udkantsområde}

Mens der i de mere centrale dele af hovedstadsmetropolen af velfærdsstaten, dens underliggende kommuner og fælleskommunale samvirker i den første efterkrigstid tilvejebragtes stadig flere regionale rammebetingelser for metropolens funktion som en byregion, forblev de ydre dele af dens åbne opland, hvor sommerhusbyerne var koncentreret til, også i den henseende et udkantsområde. Et forhold, der vanskeliggjorde såvel sommerhusbyernes optimale funktion som ferie- og fritidsbosætningssted for en del af metropolens arbejdskraft og dermed interaktion med hovedstadsmetropolens $\varnothing$ vrige funktionelt forskelligartede byenheder som håndteringen af de øvrige sideeffekter, der fulgte af sommerhusbyspredningen.

Selv om Helsingør-motorvejen på strækningen Jægersborg-Isterød åbnedes allerede i 19561957 og motortrafikvejen Isterødvejen fra Isterød til nord for Hillerød i 1965, og de to vejanlæg dermed sikrede en højklasset vejtrafikal forbindelse i retning mod den østlige del af Kattegatkystens sommerhusbybælte, stod bæltets midterste og vestlige del, sommerhusbyerne ved Roskilde Fjords nord- og østside og i Hornsherred, på nær åbningen af Holbæk-motorvejen til K. Sonderup omkring 1970, uden sådanne forbindende vejanlæg. Den $\varnothing$ gede privatbilisme og vejtrafikken til både de stedlige fremvoksende pendlersatellitbyer og de ekspanerende sommerhusbyer lagde dermed i ferie- og weekendperioder et betydeligt pres ikke blot på hovedlandevejene fra de indre dele af hovedstadsmetropolen, men i særlig grad på de amtskommunale landeveje og de sognekommunale biveje, der førte helt frem til sommerhusbyerne.

Hertil føjede sig, at metropolens sommerhusbyer, på nær dele af Kattegatkysten, der betjentes af det nordligste Nordsjællands sidebaner, alene blev dækket af den rutebilsdrift, som forskellige private rutebilsvognmænd og- seleskaber, DSB og stedlige sidebaneselskaber med amtskommunal koncession stod bag. Da ruterne særlig for de privates vedkommende skulle drives på et forretningsmæssigt grundlag, var driftshyppighed og linjeføringer tilpasset de omgivne landdistrikters kollektive trafikbehov. For beboere i sommerhusbyer uden motoriseret eget køretøj med den konsekvens, at rutebilsdriften ofte var begrænset og i weekends yderligere udtyndet, og at der ofte var en ganske betydelig gangafstand fra de lande- og biveje, som rutebilerne befærdede. ${ }^{156}$

Blev sommerhusbyernes elektricitetsforsyning sikret gennem NESA, og det fælleskommunale elektricitetsproduktionsværk, Isefjordsværket, som NESA, Frederiksberg Kommune og Nordvestsjællands Elektricitetsselskab havde været interessenter i siden 1940, blev sommerhusbyernes vandindvinding og spildvandsafledning i hovedstadsmetropolens ydre åbne opland ikke en del af de fælleskommunale ordninger, der på samme tid var eller blev etableret $i$ de indre dele af metropolen. Mens vandindvindingen her blev varetaget gennem Københavns Kommunes vandmonopol og det fælleskommunale Sjælsø-værket, var sommerhusbyerne i hovedstadsmetropolens yderområder henvist til den vandindvindingen, som stedlige lokalkommunale eller andelsbaserede private vandværker med de givne grundvandressourcer kunne tilbyde. Da disse ressourcer ofte var begrænsede i forhold til sommerhusbyernes vandforsyningsbehov, eller disse lå i en for stor afstand $\mathrm{i}$ forhold til de kommunale eller private vandindvindingsanlæg, måtte de stedlige grundejerforeninger i et ganske betydeligt antal sommerhusbyer, ofte i fælleskab, selv etablere vandværker, jf. APPENDIX VII. ${ }^{157}$

Sommerhusbyerne placering i hovedstadsmetropolens ydre åbne land bevirkede tilsvarende, at disse ikke umiddelbart blev set som en del den regionsudfordring, der i den første efterkrigstid knyttede sig til metropolens samlede regionale spildevandsudfordring. Selv om mange af metropolens sognekommuner med sommerhusbyer særlig i 60 'erne forstærkede bestræbelserne for at opnå mere tilfredsstillende spildevandsafledningsforhold, blev kun en mindre del af sommerhusbyerne kloakret. 
Udledningsmængderne fra helt eller delvist kloakerede sommerhuskommunerne var ganske vist mindre end fra bymæssige områder, men da der i disse kommuner ikke som i den indre del af hovedstadsmetropolen etableredes fælleskommunale spildevandsafledningsordninger, med fo̊ udledningssteder med kemiske eller biologiske rensningsanlæg, og spildevandet herfra blot undergik en simpel, som oftest mekanisk, rensning, kom det udledte spildevand ikke i nærheden af de standarder, der gjaldt i metropolens centrale dele. Da sivebrønde eller septiktanke på de enkelte parceller i sommerhusbyer, der ikke var kloakeret, samtidig ofte benyttedes fejlagtigt eller direkte ulovligt, kunne der i slutningen af 60 'erne særlig i Roskilde Fjord og søer inde i landet konstateres en tiltagende kritisk vandforurening. ${ }^{158}$ 


\section{Delkonklusion}

På nær værket om sommerhusområderne i det vestlige Limfjordområde er efterkrigstidens meget omfattede sommerhusbydannelser, i lighed med mellemkrigstidens, alene blevet fragmentarisk behandlet i den foreliggende litteratur, jf. Indledningen Kapitel 1. Dahlkild afsætter ganske vist 11 sider til problemstillingen i hans føromtalte redigerede værk om sommerlandets arkitektur, men som for de forudgående perioder er behandlingen her stærkt arkitekturhistorisk vinklet og fortrinsvis indsnævret til de bedre stilledes arkitektegnede sommerhuse.

Fraværende er således i litteraturen en nærmere behandling af forudsætningen for efterkrigstidssommerhusbyerne og disses karakter, bebyggelse, sociale sammensætning, boliger, forsyning og tilknyttede erhvervsliv. Tilsvarende er de særlige regionale udfordringer, der fulgte af periodens omfattende sommerhusbydannelse, og de dispositioner, som velfærdsstaten og dens underliggende kommunale lag træf for at dæmme op for sommerhusbyspredningen, perifært behandlet.

\section{Forudsætninger}

Med udgangspunkt i det Indledningens Kapitel 4 stillede hovedspørgsmål A, har denne i imidlertid påvist, at et sæt af vækstfaktorer blev forudsætningen for efterkrigstidens sommerhusbydannelse i hovedstadsmetropolen, og at denne koncentreredes til den første del af perioden. Således en økonomisk vækst, der på alle niveauer satte sig igennem i den samfundsmæssige udvikling, og tillige generede en forstærket urban vækst hovedstadsmetropolen, vækst i ferie- og fritidens omfang og vækst i forbruget.

\section{Sommerhusboom}

Mens en støt stigende tilvækst af nye sommerhuse i hovedstadsmetropolens opland $\mathrm{i}$ mellemkrigstiden og 40 'erne havde tilvejebragt 5.000 sommerhuse, svarende til 156 huse pr. àr, har bogen påvist, at der i samme regionale område i den første efterkrigstid opførtes 33.000 sommerhuse. Med 80,8 procent af efterkrigstidens samlede mængde sommerhuse, eller 1.427 sommerhus pr. år, dermed et igen sinde set voldsomt sommerhusboom.

Et boom, der for perioden 1950-1973 tillige svarede til en årlig gennemsnitlig stigning i antal sommerhuse på 23,9 procent, men som ikke kom i nærheden af den gennemsnitlige stigning på 116,7 procent pr. år, som kan udledes af Dahlkilds ansættelse af sommerhusantallet på landsplan i peroden 1945-1965; jf. Indledningens Kapitel 1. Et overdimensioneret estimat, som bogen har påvist, er betinget af, at Dahlkild fejlagtigt har sammenholdt den offentlige statistiks oplysninger om antal helårsbeboede sommerhuse i 1945 med antal ferie- og fritidsboede sommerhuse i 1965; jf. Indlednings Kapitel 1 og Del IIs Kapitel 2.

\section{Det urbane pres}

I det sæt af vækstfaktorer, der indgik som forudsætning for den første efterkrigstids sommerhusboom har bogen påvist, at hovedstadsmetropolen i perioden generede et stadig stærkere urbant pres.

Den massive urbanisering, der i den første efterkrigstid kentegnede hovedstadsmetropolen, bevirkede således, at den i 1970 havde fået et folketal på 1,7 mio. indbyggere og en $\mathrm{i}$ Danmark uset bebyggelsesmæssige udstrækning. Først ved udbygningen af de forstæder, der var opstået omkring hovedstaden frem til midten af århundredet i et 5-15 km bredt koncentrisk forstadsbælte. Samtidig og i et stadig større omfang ved dannelsen af de langstrakte radiale forstadsbånd, der i længder af 30-40 km efterhånden kom til at flyde 
sammen købstæderne i den omliggende købstadsring: Helsingør, Hillerød, Frederiksværk, Frederikssund, Roskilde og Køge.

I processen forsvandt naturområder, der hidtil havde haft en rekreative værdi eller havde potentiale for blive anvendt som să. På samme tid som afstandene fra hovedstadsmetropolens kolossale sammenbyggede urbane områder til de nærmest liggende rekreative områder blev forlænget i betragtelig grad. Samtidig med at disses mere yderlige placering i metropolens fjerne opland gjorde tilgængeligeden til dem vanskeligere.

Med denne urbaniseringsproces og dens negative sideeffekter forstærkedes modsætningen mellem arbejds- og dagligdagslivet i den yderligere fortættede hovedstadsmetropol med dens forcerede trafik, miljøbelastninger og stadig mere hektiske og monotome arbejdsliv på den ene side og på den anden frie og åbne omgivelser med mulighed for et andet liv end bylivet. Et liv ved kyster, fjorde, søer eller blot i det åbne land, der alene kunne udleves i ferie- og fritiden, men forudsatte at denne var til rådighed $\mathrm{i}$ et større omfang.

\section{Øget fritid og sommerhuslivsform}

Med den første efterkrigstids udvidede arbejdsfri tid åbnedes muligheden yderligere for et langt mere mangeartet fritidsliv for bredere samfundslag. Det være sig i form af tilkøb af underholdnings-, ferie- og charterindustriens forskelligartede aktivitetstilbud eller blot et friluftsliv. Enten i haven i eget enfamiliehuse eller i havekolonien. Eller ved aktiv idrætsudøvelse eller blot afkobling i og nydelse af naturen i alt fra bynære parkanlæg til fjernere rekreative skov-, sø og- naturområder. Med privatbilen, der efterhånden blev hvermandseje, udvidedes den geografiske aktionsradius for friluftslivet til netop sådanne rekreative områder, som det offentlige samtidig tilvejebragte og som særligt de befolkningslag, der ikke økonomisk magtede fast ejendom, eller måske valgte den fra, måtte henlægge friluftslivet til. Var der for disse grupper en smule mere økonomisk overskud, blev drømmen om eget hus eller sommerhus udlevet i den campingvogn, der erstattede teltet, eller i de almennyttige feriebyer, som senere udviklede sig til feriecentre med et stort udbud af forskelige former for aktiviteter.

For den del af hovedstadsmetropolens befolkning, der økonomisk magtede både at have en lejebolig $i$ en etagebebyggelse eller et enfamiliehus og samtidig at erhverve og besidde et sommerhus, førte metropolens stærke urbane pres til, at denne fritids- og feriebosætningsform som ramme for friluftlivet blev eftertragtet. Mens et sommerhus i fredelige, landlige og rekreative omgivelser i den første efterkrigstid, som i mellemkrigstiden og 40 'erne, fortsat, som tillige påvist i den internationale turismeforskning, kompenserede for det levevilkărsunderskud, som bylivet og helårsboligen i den fortættede hovedstadsmetropol var udtryk for, ændredes sommerhusets hidtidige brugsværdi. Med periodens stigende realindkomster og relativt billigere fødevarepriser, kom dyrkningen af grønsager ikke som hidtil til udgøre et nødvendigt supplement til husholdningsøkonomien. Da størsteparten af hovedstadsmetropolens befolkning i efterkrigstiden ikke som forældre- og bedsteforældregenerationerne havde samme veneration for et tidligere liv i provinsens landdistrikter, mistede denne form for havedyrkning samtidig sin funktion som erstatningsobjekt for en tabt rural livform.

Til gengæld blev sommerhuset, som tillige påvist af den internationale turismeforskning, med sin naturnærhed og mulighed for her at udleve en anden og mere rustik livsform en kompensation for både efterkrigstidens veludstyrede helårsboliger og det bymæssigt hektiske og stereotype arbejds- og familieliv. Et miljøskift i ferie- og fritiden, hvor genkendelige rutiner fra det hjemmelige $i$ et sommerhus kunne kombineres med følelsen af at være langt væk hjemmefra og her at have "frihed" og tid til afslapning, mere samvær og naturoplevelser. 


\section{Økonomisk vækst}

Et gode for bredere samfundslag, som bogen påviser, opnåedes ved den første efterkrigstids større økonomisk råderum, der kunne dække de udgifter, der knyttede sig til erhvervelse af elementære livfornødenheder og en helårsbolig, men som samtidig gav økonomiske ressourcer til at have den sekundærbolig, som sommerhuset udgjorde.

Samfundsøkonomisk blev den første efterkrigstid således kendetegnet af: Dels en voldsom mekaniseringsproces i landbruget med afvandring fra og en massiv ejendomskoncentration i erhvervet til følge. Dels endnu en industrialiseringsbølge og vækst i de øvrige byerhverv. Stærkt forandrede økonomiske vilkår, der udgjorde forudsætningen for, at den først efterkrigstid blev den periode i det 20. århundrede, hvor den økonomiske vækst og væksten i både rådighedsbeløbet og det samlede konsum blev størst.

Den kraftige vækst i konsumet var udtryk for en massiv forøgelse af det private forbrug, der fulgte med den kraftige økonomiske vækst, og som generede betydelige forskydninger i sammensætningen af det samlede forbrug. Den andel af det samlede forbrug, der anvendtes til basale livsfornødenheder, fødevare, fodtøj, beklædning, bolig og brændsel m.v. faldt således markant mellem 1939 og 1970, mens de øvrige forbrugsposter i samme periode opnåede betydelig større andele. Af disse fik i forhold til udgangspunktet i 1939 varige forbrugsgoder, herunder sommerhuse, den største stigning og opnåede den andenstørste andel af de forbrugsenheder, der faldt uden for de basale livsfornødenheder.

\section{De ekspanderende sommerhusbyer}

På grundlag af det i Indledningens Kapitel 4 givne hovedspørgsmål B har bogen endvidere afdækket en række karakteristiske træk ved hovedstadsmetropolens efterkrigstidssommerhusbyers lokalisering, karakter, bebyggelse, sociale sammensætning, boliger, forsyning og tilknyttede erhvervsliv.

\section{Byfænomen og lokalisering}

Nye og kraftigt udvidede ældre sommerhusbyer blev således i den første efterkrigstid et markant bymæssigt fænomen i hovedstadsmetropolens åbne land udenfor købstadsringen på samme tid, som større landsbyer og stationsbyer med omgivne bælter af enfamiliehuse her omdannedes til pendlersatellitbyer. En særegen urbaniseringsproces afledt af det stadig større befolkningsvolumen og den stadig større udbredelse, hovedstadsmetropolen opnåede i perioden. Og dermed en følge af, at en stadig større del af hovedstadsmetropolens befolkning søgte ud af de tætbebyggede hovedstadsbydele, forstæder og omgivende købstæder i købstadsringen for uden for denne del af metropolen enten at erhverve et enfamiliehuse i frie og rurale omgivelser til en mere rimelig pris eller at udleve et fritids- og friluftsliv i et sommerhus ved de kyst-, fjord- og søbredder, som indgik blandt nogle af attraktionerne i hovedstadsmetropolens åbne land.

Mens sommerhusbybæltet langs Køge Bugt i den første efterkrigstid blev opsuget i det radiale forstadsbånd, der lagde sig ned langs bugten, udvidedes de 23 ældre sommerhusbyer i det særdeles attraktive sommerhusbybælte ved Kattegatkysten i sådant omfang, at de sammen med to nye sommerhusbyer $\mathrm{i}$ indlandet kom til at rumme mere end halvdelen af periodens sommerhuse. Da ejendomspriserne lå særlig højt i Kattegatkystens sommerhusbybælte, og dette efterhånden opfyldtes med bebyggelse, blev den mindre halvdel af den første efterkrigstids sommerhuse lokaliseret til tre ældre og stærkt udvidede sommerhusbyer og 46 nye beliggende ved andre af hovedstadsmetropolens kystnære områder.

Af disse udgjorde kystbæltet langs Roskilde Fjords nord- og østside det nærmeste, hvor der i midten af det 20. århundrede samtidig endnu ikke var blevet bebygget i videre omfang. Da kystbæltet overvejende udstykkedes i løbet af 50 'erne, og dets syv nye sommerhusbyer i dette årti og særlig i 60 'erne bebyggedes i et så betydeligt omfang, at de kom til rumme mere 
end en ottendel af hovedstadsmetropolens samlede mængde sommerhuse, blev udbuddet af ledige grunde også her gradvist reduceret med stigende grundpriser til følge.

Selv om Hornherred omfattede en ældre stor sommerhusby, og sommerhusudstykninger- og bebyggelser var påbegyndt på halvøens nordvestlige del ud til Isefjorden i løbet af 50 'erne, blev det først i løbet af 60 'ere, at der her gennemførtes vidtgående udstykninger og bebyggelser. Samlet kom Hornsherreds 18 sommerhusbyer ved udgangen af den første efterkrigstid til at omfatte godt en femtedel af hovedstadsmetropolens sommerhusvolumen, og suppleredes i den sidste del af perioden med ydrelige to mindre sommerhusbyer.

Den sidst tiendedel efterkrigstidssommerhusene blev fordelt på to ældre sommerhusbyer ved Køge Bugts øst- og sydside og 17 nye sommerhusbyer. Spredt på det øvrige Nordøstsjælland, men hovedsagelig ved dettes store søer og i udkanten af hovedstadsmetropolens nordforstæder.

\section{Sommerhusbyens karakter}

Endskønt hovedstadsmetropolens sommerhusbyer fordelte sig geografisk og tidsmæssigt forskelligartet gennem hele efterkrigstidsperioden, har bogen afdækket, at disse fik en række fællestræk. Det drejede sig om de størrelseskategorier disse fordelte sig på og den bebyggelsesmæssige struktur og udvikling, der kendetegnende dem. Herudover skabte sommerhusbyernes volumen og regionale fordeling grundlag for en egentlig erhvervsmæssig udvikling, ligesom el- og vandforsyningen og håndteringen af spildevandsafledning fik en række fælles kendetegn.

\section{Bebyggelse}

Af hele efterkrigstidens 40.000 sommerhuse i hovedstadsmetropolen blev tre fjerdedele opført i de knapt 40 procent af de 71 sommerhusbyer, der omfattede mere end 500 huse. Fordelt med 60 procent i den fjerdedel af sommerhusbyerne, der rummede mere end 1.000 sommerhuse, og med 15 procent i de 14 procent af sommerhusbyerne, som omfattede mellem 500-1.000 huse. Med denne betydelige koncentration blev alene en fjerdel af hovedstadsmetrolens efterkrigstidssommerhuse lokaliseret til de 60 procent af mellemstore og mindre sommerhusbyerne, der rumme op til 500 sommerhuse.

Lige på nær det fătal af sommerhusbyer, der med godt en procent af hovedstadsmetropolens samlede sommerhusvolumen i efterkrigstidens skød op i de indre dele af metropolens àbne land, opstod hovedparten ved kyst-, fjord- eller søbredder. Uanset om de på disse lokaliteter var vokset frem før midten af det 20 . århundrede og i efterkrigstiden udvidedes på dette grundlag, eller de i perioden opstod som nye, fik de alle en karakteristisk bebyggelsesstruktur.

Ud fra en tidlig bebyggelse langs kyst-, fjord- eller søbredderne, om det så var i ældre eller nyudlagte sommerhusbyer, dannedes sommerhusbyerne således som tidsmæssigt forskudte koncentriske bebyggelseslag langs side- og parallelveje til veje langs bredderne eller til ældre sideveje, der første frem til disse. I de mindre og mellemstore sommerhusbyer over nogle hundrede meter langs kyst-, fjord- eller søbredderne og ind i baglandet. I de store og større sommerhusbyer med en udtrækning over en $\mathrm{km}$ langs bredderne og ind i baglandet og ved Kattegatkysten i et næsten uafbrudt 50 km langt sommerhusbybælte, der strakte sig op til seks $\mathrm{km}$ ind $\mathrm{i}$ baglandet.

Selv om vej- og bebyggelsesstrukturen blev mere ensartet og sammenhængende i hovedstadsmetropolens efterkrigstidssommerhusbyer som følge af en mere indgribende lokalkommunal planindsat, kunne den ikke hindre en stærk koncentreret bebyggelse. Af hensyn til størst mulig fortjeneste lykkedes det for de udstykkende at få udparcelleret så mange sommergrunde som muligt. Med den konsekvens for de enkelte sommerhusbyer, at stedlige højdedrag, mindre plantager og i realiteten uanvendelige engarealer senere bebyggedes, og at der ofte ikke udlagdes fællesarealer, eller at disse fik et yderst begrænset 
omfang og ikke kom til at indgå i en rationel sammenhæng med selve sommerhusbebyggelsen.

Efter førnævnte af Dahlkild redigerede værk og en del af den øvrige litteratur, der behandler efterkrigstidens sommerhusbyer, fik de med stereotypt udlagte veje og haver og fjern beliggenhed fra kystnære områder en bebyggelsesstruktur, som svarede til forstædernes endeløse parcelhuskvarterene, hvorved sommerhusbyerne mistede deres "anderledeshed". Jf. Indledningens Kapitel 1. En forståelse af hovedstadsmetropolens efterkrigstidssommerhusbyer, som imidlertid ikke kan genkendes i analyserne bag denne bog.

Ganske vist bredte sommerhusbyerne her og særlig ved Kattegatkysten sig godt ind $\mathrm{i}$ baglandet, men netop nærheden til de stedlige kyst-, fjord- og søområder forblev den helt afgørende lokaliseringsfaktor for sommerhusbyerne, hvorved afstanden til disse herligheder $\mathrm{i}$ sig selv lagde en maksimal grænse for, hvor langt sommerhusbyerne kunne brede sig uden, at de mistede sin attraktion. Hertil kom, at offentlige myndigheders regionale plandispositioner fra 60 'erne og i de følgende årtier søgte at afgrænse sommerhusbyspredningen, således at den netop af hensyn til kystnærheden ikke bredte sig for langt langs kyst-, fjord- og søbredderne eller ind i baglandet. Dispositioner der ganske vist tog størst hensyn til almenhedens adgang til de kystnære områder, men som tillige havde betydning for fastholdelsen af sommerhusbyernes kvalitet for disses fritidsbeboere.

Kvaliteter, der sammen med efterkrigstidssommerhusbyernes tætte beplantning med nåletræer, smalle og ofte snoede veje uden vejbelysning, fortov, rendestene, asfaltbelægning og mindre og langsomt kørende trafik netop gav dem den forskelligartethed i forhold til forstadens villakvarterer, at de i fritiden gav mulighed for her at udleve en anden og mere rustik livsform med "frihed", afslapning, mere samvær og naturoplevelser fjernt fra hovedstadsmetropolens veludstyrede helårsboliger og dens hektiske og stereotype arbejds- og familieliv. Ud over kystnærheden netop den helt afgørende forudsætning for, at sommerhusbyerne forblev anderledes og i sig selv en forklaring på det paradoks, at en større andel af hovedstadsmetropolens førstegangssommerhusejerne i langt større udstrækning end dens samlede befolkning beboede et enfamiliehus og i højere grad havde bopæl i metropolens nordlige velhaverforstæder og noget bedre stillede forstæder på Nordvestegnen, hvor tilgængelighed til betydelige omgivne rekreative områder var langt større end andre steder i den indre del af hovedstadsmetropolen.

\section{Ulighed}

En ulighed i førstegangssommerhusejernes bolig- og bopælsforhold i forhold til hovedstadsmetropolen som helhed, der indgik i den ulige sociale fordeling af det gode, som et af sommerhus udgjorde. En ulighed, som værket om sommerhusområderne i det vestlige Limfjordsområde ser komme til udtryk ved, at mellemlaget af øvrige funktionærer og mindre selvstændige her udgjorde den overvejende del af de stedlige sommerhusejere, Jf. Indledningens Kapitel 1.

Endskønt arbejderklassens andel af den førte efterkrigstids førstegangssommerhusejere i hovedstadsmetropolens sommerhusbyer $\varnothing$ gedes en smule i forhold til tiden før midten af det 20. århundrede, og dokumenterer bogen săledes, at arbejdere forsat kom til at udgøre en langt mindre del af ejergrupppen i forhold til deres, i øvrigt svagt faldende, andel af hovedstadsmetropolens erhvervsbeskæftigede. I forhold hertil forblev laget funktionærer og selvstændige stærkt overrepræsenteret som førstegangsejere i periodens sommerhusbyer. Dog således at funktionærerne, og særlig laget af øvrige funktionærer, i forhold til mellemkrigstiden og 40 'erne, opnåede en større andel af periodens førstegangssommerhusejerne, uden at det rykkede ved, at højindkomstlaget af større selvstændige og højere funktionærer fortsat tegnede sig for en betydelig andel af ejergruppen. 
Med den forsat ulige fordeling af det gode, som et sommerhus udgjorde og den første efterkrigstids stærkt forøgede samfundsmæssige indkomst, der særlig kom højindkomstlagene til gode, blev periodens sommerhusbyggeri med dets bagvedliggende moderne byggeteknologi kendetegnet af et markant kvalitative løft. I forhold til mellemkrigstidens og 40'erne sommerhuse har bogen påvist, at den første efterkrigstids sommerhuse fik langt færre med 12 værelser, mens mere end halvdelen kom til at rumme 3 værelser. Markant flere fik installeret toilet og bad, på samme tid som huse uden køkken blev forsvindende. Over halvdelen af den første efterkrigstids sommerhuse blev fuldisolerede, mens denne beskyttelse mod kulde og vind i mellemkrigstidens sommerhuse alene opnåedes i det lille mindretal, der var grundmurede.

Størrelsesforholdet mellem grundmurede og af træ opførte sommerhuse forblev ganske vist det samme i den første efterkrigstid som i perioden op til 1950, men til gengæld blev langt hovedparten af efterkrigstidssommerhusene opført på et støbt fundament. Endelig udrustedes den første efterkrigstids sommerhuse i langt højere grad med bekvemmeligheder end sommerhusene fra mellemkrigstiden og 40 'erne. Det være sig de opvarmningsmuligheder, som en skorsten ydede, på samme tid som elpaneler i den første efterkrigstid gav en ny opvarmningsmulighed, omfanget af sommerhuse med indlagt vand og spildevandsafledning til sivebrønd eller septiktank.

I den foreliggende litteratur, herunder Dahlkilds førnævnte redigerede værk, ses det kvalitative løft, sommerhusbyggeriet opnåede som udtryk for, at efterkrigstidens arkitekttegnede eller industrielt masseproducerede sommerhuse fik samme isoleringsgrad, udstyr og indretning som helårsboligens, hvorved de nærmede sig parcelhusets standard. En karakteristik, som dog for den første efterkrigstids sommerhuse i hovedstadsmetropolens sommerhusbyer som helhed ikke er dækkende, men snarere, som påvist i denne bog, må betragtes som misvisnede. I sin begejstring over den absolutte overklasses arkitektegnede sommerhuse overser Dahlkild, at andelen af sådanne huse i perioden, som dokumenteret i bogen, reduceredes stærkt for at lægge sig på en tiendel af samtlige opførte sommerhuse samtidig med, at over en tredjedel af disse stadig blev flikket sammen af selvbyggere og lokale bygmestre, og at mere end halvdelen opførtes som de typesommerhuse, der dannede grundlag for en ny branche indenfor bygge- og anlægssektoren.

Typesommerhuse, der for tæet ved halvdelen af disse lå under den gennemsnitsstørrelse -og standard, som kendetegnede hovedstadsmetropolens sommerhuse i den første efterkrigstid. Et gennemsnitsommerhus, som bogen har påvist, var på $52 \mathrm{~m}^{2}$ og rummede 2-3 værelser. Af metropolens samlede mængde sommerhuse fra perioden var desuden 18, 52 og 40 procent uden toilet, bad og skorsten, omkring 10 procent opført på piller, knapt 10 procent ikke forsynet med indlagt vand og spildevandsafledning til sivebrønd eller offentlig kloak. Forhold der ikke just svarede til både ældre eller nye enfamiliehuse i de helårsbeboede dele af hovedstadsmetropolen i den første efterkrigstid, men var udtryk for den ganske vist forsat socialt skæve, men alligevel noget jævnere fordeling af førstegangsommerhusejere.

\section{Forsyning}

Som i en hver anden by, har bogen dokumenteret, at forsyning med vand og energi og spildevadsafledning tillige indgik som en del af karakteren af hovedstadsmetropolens efterkrigstidssommerhusbyer. Allerede inden midten af det 20. århundrede havde NESA varetaget elektricitetsforsyningen af samtlige sommerhusbyer i metropolen, og det blev da også dette af Gentofte Kommune ejede elektricitetsselskab, der kom til at stå for denne forsyningsopgave i takt med, at disse byer udbygges i efterkrigstiden og nye opstod.

Da der i hovedparten af de sommerhusbyer, der i efterkrigstiden udvidedes på grundlag af sommerhusbydannelser fra mellemkrigstiden og 40 'erne, allerede var etableret lokale vandværker, og en del af periodens ny sommerhusbyer lă så tæu ved nærmeste købstad, stationsby eller større landsby, at disses vandforsyningsanlæg kunne udvides hertil, opnåede 
tæt ved halvdelen af periodens sommerhuse vandforsyning fra allerede eksisterende kommunale eller private, ofte andelsejede, vandværker. For den større halvdel af sommerhusene i efterkrigstidens sommerhusbyer, i hovedsagen dem der opstod som mere isolerede bydannelser $\mathrm{i}$ hovedstadsmetropolens fjernere åbne land, måtte vandforsyningen til gengæld etableres fra grunden. I sommerhusbyer med knapt en femtedel af hovedstadsmetropolens samlede sommerhusmængde påtog lokalkommunerne sig vandindvindingsopgaven, mens den i de øvrige sommerhusbyer med mere end en tredjedel af sommerhusene blev overladt til de stedlige grudejerforeninger, der etablerede såvel vandværker som hovedvandforsyningsnet.

Opnåedes der i efterkrigstiden en fuldstændig elektricitets- og vandforsyning i hovedstadsmetropolens sommerhusbyer, og disses vejsystemer samtidig udlagdes af de stedlige udstykkere eller grudejerforeninger, kneb det med den del af byggemodningen, der omfattede offentlig kloakering. Ved udgangen af efterkrigstidsperioden i 1990 var der således kun gennemført en delvis kloakering af metropolens sommerhusbyer, hvorved alene godt halvdelen af dens sommerhuse var blevet tilsluttet et offentligt kloaknet og dermed den spildevandsbehandling, som det samtidig større antal lokalkommunale rensningsanlæg muliggjorde. I den meget betydelige del af sommerhusbyerne med den mindre halvdel af hovedstadsmetropolens sommerhuse, blev spildevandsafledningen i efterkrigstiden dermed baseret på sivebrønde eller septiktanke.

Den eneste formildende faktor i den forbindelse var, at langt hovedparten af metropolens sommerhuse tilsluttedes sådanne spildevandsanlæg, hvorved den tidligere ganske udbredte nedgravning af fækalier og udhældning af urin og husholdningsspildevand på de enkelte grunde eller i nærmeste vandløb stoppede. At grundvandsnedsivning fra sivebrønde eller ulovlig anvendelse af septiktanke blev mere udbredt, blev så en ny miljøudfordring.

\section{Erhverv}

Bydannelse og erhvervsudvikling blev også i hovedstadsmetropolens efterkrigstidssommerhusbyer forbundet. Mens nærmest liggende fiskerleje, større landsby, stationsby, købstad eller forstadsbydel dækkede behovet for dagligvare og håndværksmæssige ydelser $\mathrm{i}$ et betydeligt antal af efterkrigstidens sommerhusbyer, har bogen dokumenteret, at periodens sommerhusbydannelse skabte basis for en byerhvervsmæssig udvikling i knapt en tredjedel af de sommerhusbyer, som rummede over halvdelen af metropolens sommerhusvolumen. I hovedsagen i de store, større og i nogle tilfælde også mellemstore sommerhusbyer, der lå tilpas langt fra en større eksisterende bymæssig bebyggelse, og samtidig havde et volumen, som muliggjorde en selvstændig erhvervsudvikling.

Faktorer, der samtidig blev afgørende for, hvor differentieret erhvervsstrukturen blev i de enkelte sommerhusbyer. Nogle fik således kun en enkelt købmandshandel, et mælkeudsalg eller et supermarked, mens de store sommerhusbyer fik forskellige former for detailhandel og håndværksvirksomhed. Det være sig bageri, ismejeri, slagterforretning, købmandshandler, supermark og blomsterforretning, der nogle steder koncentrerede sig til selvgroede centerområde ved en gennemgående større vej. Hertil kom planteskole, tømrer- og snedkerværksted, autoværksted, VVS-virksomhed, tømmerhandel autolakereri, cykelforretning, benzintank, vognmandsforretning, cafeteria, resturent, flere is- og pølseudsalg, grill, motel og diskotek.

Ud over de badehoteller, pensionater, kurbadeanstalter, ferie- og sommerlejre, der forsatte den hidtidige virksomhed, blev der til de store og større sommerbysbyer i efterkrigstiden samtidig knyttet vandrehjem og anden virksomhed, der tilbød alternativ fritidsbosætning til sommerhusene. Det være sig flere ferie- og hvilehjem, de to kolonier med småhytter, som motorcykelklubben Ariel etablerede, de campingpladser som almennyttige Danmark Lejrsport, senere Dansk Campingunion, og private udlagde ved 10 af sommerhusbyerne og de fire 
feriebyer - eller kolonier med småhuse og fælleslokaler med et stadig større udbud af aktiviteter, som arbejderbevægelsen, Dansk Folkeferie og fagforbund, stod bag. Hertil kom kursus- og feriecentre, efter- og specialskoler og et større antal nye ferie- og sommerkolonier.

\section{Regionale forskelle}

Mens den foreliggende litteratur giver indtryk af, at efterkrigstidens sommerhusbyer var ganske homogene, har denne bog endelig påvist, at hovedstadsmetropolens sommerhusbyer i perioden blev kendetegnet af markante regionale forskelle for så vidt sociale sammensætning, sommerhusbebyggelsens karakter, forsyning og erhvervsudvikling.

Med den meget store andel højindkomstlaget af større selvstændige og højere funktionærer opnåede som førstegangsejere i Kattegatkystens sommerhusbybælte, og i nogen grad også i sommerhusbyerne i kystens fjerne bagland og ved Strøby Strand på Køge Bugt sydside, blev den første efterkrigstids sommerhusene her både større og mere veludrustede end $\mathrm{i}$ hovedstadsmetropolens sommerhusbyer som helhed. Det blev da også her, at de dyrere og mere luksuøse typesommerhuse gennemsnitligt blev mere udbredte.

Da en betydelig del af efterkrigstidens sommerhusbydannelse ved Kattegatkysten var vokset ud af ældre sommerhusbyer, der allerede havde făet vandforsyning eller lå i nærheden af fiskerlejer, fra hvilke vand kunne leveres fra de stedlige vandværker, blev det kun i begrænset omfang her overladt til stedlige grudejerforeninger at etablere vandværker og udlægge et hovedvandforsyningsnet i større omfang. Med Kattegatkystens meget koncentrerede bebyggelse med både sommerhusbyer og fikserlejer, hvoraf flere var ganske store eller tillige havde karakter af stationsbyer, blev hovedparten af sommerhusbyerne her kloakeret inde udgangen af efterkrigstiden. De korte afstande til fiskerlejerne bevirkede endvidere, at det alene i de fjerenere beliggende sommerhusbyer, mellem Hornbæk-Gilleleje og GillelejeRågeleje og i Asserbo, at der, tillige på basis af sommerhusbyernes betydelige volumen, skabtes grundlag for en mere differentieret erhvervsudvikling inden for detailhandel og håndværksmæssig virksomhed.

I forhold til Kattegats sommerhusbybælte fik efterkrigstidens sommerhusbyer i Hornsherred en yderst forskelligartet udvikling og karakter. De lavere og mellemste indkomstgrupper af arbejdere, øvrige funktionærer og mindre selvstændige kom her til at udgøre den største andel af førstegangsommerhusejere end i hovedstadsmetropolen som helhed. En social sammensætning af denne ejergruppe, som bevirkede, at sommerhusene i Hornsherred blev de mindste og dårligst udrustede, og at de billige typesommerhuse her blev mest udbredt.

Som konsekvens Hornsherreds placering i udkanten af hovedstadsmetropolens åbne land, lave urbaniseringsgrad og dermed mangel på større bydannelser med flere og mere differentierede byerhverv, kom de mellemstore, større og store sommerhusbyer her til at dannede grundlag for en bredere bymæssig erhvervsudvikling end andre steder i metropolens sommerhusbyer. Ikke blot inden for detailhandel, men også for så vidt håndværksvirksomhed og serviceerhverv. Sommerhusbyernes isolerede beliggenhed bevirkede desuden, at de stedlige grundejerforeninger her $\mathrm{i}$ alt overvejende grad måtte stå for etablering af lokalvandværker og dertil hørende hovedvandforsyningsnet, ligesom kun en mindre del af sommerhusbyerne blev kloakeret i efterkrigstidsperioden.

Mellem de to yderpunkter, som sommerhusbyerne i Hornsherred og ved Kattegatkysten repræsenterede, blev både sammensætningen af førstegangssommerhusejere, sommerhuskvalitet og- størrelse og fordelingen typesommerhuse mere jævn i sommerhusbyerne ved Roskilde Fjords nord- og østside. Da en betydelig del kyststrækningens sommerhusbyer lå i nærheden af købstæder og stationsbyer, blev det kun i de mest isolerede sommerhusbyer, hvor de stedlige grundejerforeninger måtte etablere egne vandværker og udlægge hovedvandsforsyningsnet. Afstanden til andre og ældre byer medførte tillige, at det 
alene blev i den store og fjernt beliggende sommerhusby Jyllinge, at der skabtes grundlag for en større og mere differentieret erhvervsudvikling.

\section{Sommerhusbyerne og hovedstadsmetropolens regionsudfordringer}

Med den første efterkrigstids meget store sommerhusbydannelser fulgte en større buket af udfordringer for både lokalsamfundene og af regional karakter. Særlig de regionale forstærkedes og blev kritiske i forhold til velfærdsstatens vækstforudsætninger og kultur- og fritidspolitiske målsætninger. Et sæt af regionsudfordringer, der sammen med hovedstadsmetropolens øvrige blev overladt til dens uforandrede politisk-administrative rammestruktur suppleret med statslige etapevise regionsløsninger.

\section{Den byregionale interaktionsudfordringer}

Har den hidtidige kulturhistoriske og kultursociologiske arkitekturhistoriske litteratur om den første efterkrigstids sommerhusbyggeri blot tangeret de både lokale og regionale udfordringer, som dette genererede, har denne bog med afsæt i hovedspørgsmål $\mathrm{C}$ i Indledningens Kapitel 4 påvist, at sommerhusbyerne med deres stadig større udbredelse i hovedstadsmetropolens udkant i perioden ikke blot blev en udløber af metropolens stadig kraftigere industrialiseringsog urbaniseringsproces, men tillige i langt højere grad kom til at indgå i den regionale interaktion mellem metropolens byenheder, der omfattede udveksling af arbejdskraft, varer, tjenester virksomheds-, bygge- og jordkapital, information og kulturer. En interaktion, der indebar, at barrierer eller manglende forudsætninger for denne udgjorde en regional udfordring for hovedstadsmetropolens funktion som en byregion.

I forhold hertil kom den første efterkrigstids omfattende regionale sommerhusbyspredninger til at skabe regionale barrierer for bygge- og jordkapitalens regionalt mest rationelle placering af en del arbejdskraftens sommerhuse og øvrige ferie- og fritidsboliger, industri- og forretningskapitalens regionalt mest hensigtsmæssige lokalisering af produktions- og servicevirksomheder i de dele af yderområder af hovedstademetropolen, hvor sommerhusbyerne lokaliseredes til, og offentlige aktørers optimale regionale føring af trafik-, forsynings-, kommunikations- og spildevandslinjer.

Sammen med de fjernere forstads- og pendlersatellitbydannelser voksede de vidtstrakte sommerhusbyer på samme tid stadig længere ud i det åbne land og lagde beslag på, spærrede adgangen til og ødelagde kyst- og skovoplande og samtidig med, at meget store og kompakte sommerhusbyer mistede sin rekreative værdi for sommerhusejerne. Følgelig en yderlige begrænsning af de rekreative friluftsmuligheder, der var afgørende for metropolarbejdskraftens reproduktion og levevilkår og dermed dens evne til at indgå i hovedstadsmetropolens produktion og interaktion mellem den funktionelt forskelligartede byenheder.

Herudover skabte den første efterkrigstids ekspanderende sommerhusbyer en række andre regionale udfordringer. Med privatbilens stadig større udbredelse havde det regionale vejnet i de ellers rurale områder ikke en tilstrækkelig kapacitet til at bære trafikken til og fra sommerhusbyernes befolkningskoncentrationer. Store sommerhusbyer, der samtidig med den stadig mere udbredte installation af wc og bad i sommerhuse, udledte betydelige spildevandsmængder i forhold til de omgivende landdistrikter, hvis spildevandsafledningsforhold ofte var yderst primitive.

\section{Velfærdsstatens aktionsfelt}

I forhold til det stadig mere udvide aktionsfelt velfærdsstaten opnåede op gennem den første efterkrigstid, har bogen samtidig dokumenteret, at sommerhusbyspredningen blev kritisk i forhold til statsformens samfundsøkonomiske og sociale sigte. Med de barrierer, som sommerhusbyerne var med til at lægge for kapitalens mest rationelle investeringer og offentlige aktørers linjeføring og konkrete udlæg af regionale trafik-, forsynings-, kommunikations- og spildevandslinjer, blev disse kritiske i forhold til den økonomiske vækst i 
hovedstadsmetropolen, der efter vækstcenterteorien ville forplante sig til resten af landet, og dermed var en forudsætning for velfærdstatsstatsformen.

Mest kritisk blev sommerhusbyernes udbredelse i det åbne land, ødelæggelser af dettes kulturog naturhistoriske værdier og afspærring og reduktion af tilgængelige rekreative områder for almenheden. Med den øgede fritid, der opnåedes i den første efterkrigstid, fik den kultur- og firtidspolitiske søjle i velfærdstaten en endnu mere central rolle. Målet blev som hidtil at give de brede samfundslag adgang til kultur- og fritidstilbud, men spektret for de kultur- og fritidspolitiske tilbud udvidedes og kombineredes. Centralt forblev bestræbelserne for at bidrage til de brede samfundslags fysiske og intellektuelles højnelse bl.a. gennem forskellige former for friluftsliv i også fjernere rekreative områder, som den stadig mere udbredte privatbilisme gav mulighed for. Det være sig fri individuel udfoldelse i sådanne områder eller mere organiseret i kolonihaver, på campingpladser eller i almennyttige feriecentret, der samlet repræsenterede et alternativ til de mere velbjergedes sommerhuse.

\section{De politisk-administrative rammer}

Skønt mange af sommerhussognekommunerne særlig i 60 'erne i et vist omfang fik forbedrede muligheder for at håndtere de lokale udfordringer, der knyttede sig til den første efterkrigstids sommerhusbydannelser, har bogen påvist, at deres udbredelse over stadig flere kommuner og større dele af det åbne land tillige blev en regional politisk-administrativ udfordring. Som for hovedstadsmetropolens øvrige regionsudfordringer blev det i forhold til dem, der også fulgte med sommerhusbyerne, spørgsmålet om, hvorvidt og i hvilket omfang staten eller metropolens kommunale politisk-administrative rammestruktur havde evnen til eller muligheden for at håndtere disse.

Med hovedstadsmetropolens stadig større udbredelses i den første efterkrigstid forstærkedes dens kommunestruktur på samme tid som en selvstændig regional udfordring.

Hovedstadskommissionen fra 1938 havde ganske vist i sin betænkning fra 1948 lagt op til forandring af denne struktur i forhold til metropolens lokale og regionale udfordringer, men dens indstilling og det efterfølgende politiske spil blev så mudret, at Rigsdagen stiltiende ved en opgradering af de indre forstadskommuner til en semikøbstadskommunale status i 1952 tilsluttede sig den skitse til en decentral hovedstadsordning, som regeringen fremsatte på samme tid.

Ud over den nævinte opgradering fastholdt ordningen hovedstadsmetropolens hidtidige forstads-, hovedstads-, købstads- og amtskommunale opgavefordeling og inddeling, og rummede ikke som Hovedstadskommissionens betænkning et regionalkommunalt organ til varetagelse af metropolens regionale udfordringer. Disse blev i den decentrale hovedstadsordning overladt til en særlig hovedstadskonference, hvor hovedstadsmetropolens forstads-, hovedstads-, købstads- og amtskommuner kunne drøfte forslag til regionale løsninger, herunder oprettelses af et kommunalt regionsorgan, som så efterfølgende skulle kunne danne grundlag for den nødvendige lovgivning. Da denne konference i form af i 1956 nedsatte Hovedstadskommunerne Samrăd i realiteten intet opnåede, blev størsteparten af hovedstadsmetropolens regionsudfordringer overladt til de etapevise statslige regionsløsninger, som tillige indgik i den decentrale hovedstadsordning. Da egnsplanlægning, herunder fredningsplanlægning, indgik i disse statslige etapeløsninger og tillige kom til omfatte sommerhusbydannelserne, blev de regionsudfordringer som disse genererede i den første efterkrigstid forsøgt løst inden for disse planrammer.

\section{Regionale plandispositioner}

Mens der i mellemkrigstiden og 40'erne ikke tilvejebragtes regionalplanmæssige virkemidler til at imødegå den planløse regionale byspredning og fordeling af bebyggelsesarter, har den byplanhistoriske litteratur tegnet et løseligt billede af de egns- og fredningsplansinstrumenter, der tilvejebragtes i den første efterkrigstid. Da denne litteraturs behandling af disse regionale plandispositioner har en yderst oversigtmæssig karakter, og bl.a. ikke nærmere belyser, 
hvorledes og i hvilket omfang de øvede indflydelse på håndteringen af de regionale udfordringer, der fulgte af periodens samtidige sommerhusbyspredning, har bogen med udgangspunkt i det i Indledningens Kapitel 4 give hovedspørgsmål $D$ taget denne problemstilling op til nærmere behandling.

\section{Egnsplanlægning}

Med udgangspunkt i egnsplanskitserne Fingerplanen fra 1948 og Principskitsen og dennes Første Etapeplan fra starten af 60 'erne, gennemførtes ved byudviklingsplaner og den særlige Køge Bugtdispositionsplan en egentlig regional fysisk planlægning i den første efterkrigstids hovedstadsmetropol. Mens det på dette plangrundlag i den indre del af hovedstadsmetropolen med grønne kiler mellem forstadsbåndene og andre rekreative arealudlæg, så som tværgående grønne bånd og Vestskoven, lykkedes at tilvejebringe meget betydelige rekreative områder og dermed også her at inddæmme dannelsen af nye sommerhusbyer, har bogen påvist, at der i 50'erne og til et godt stykke op i det følgende tiår ikke blev opnået tilsvarende resultater i hovedstadsmetropolens ydre åbne opland.

Ved udarbejdelse af byudviklingsplaner for byudviklingsområderne omkring købstæderne i købstadsringen i Frederiksborg og Roskilde amtskommuner, blev eksisterende sommerhusbyer og udlæg af nye ikke underlagt byudviklingsplanlægningen. Byudviklingsområderne for købstadsringens købstæder omfattede således ikke hovedstadsmetropolens fremvoksende sommerhusbyer i de sydlige dele af Hornsherred, på nord- og østsiden af Roskilde Fjord, ved Strøby Strand og kun en lille del af dem, der var beliggende langs Kattegatkysten. Hertil kom, at de stedlige byudviklingsplaner omkring disse købstæder udarbejdes langt senere end dem for hovedstadsmetropolens indre del, og kun udlagde smalle yderzoner omkring de i forvejen små inder- og mellemzoner, der lagdes om købstæder, stations- og landsbyer. Yderzoner, som dermed ikke nåede ud til sommerhusbyerne, og der ikke kunne bremse disses videre spredning.

Udsugede byudviklingsplanerne for den indre del af hovedstadsmetropolen og det nordlige delbyudviklingsområde i den første efterkrigstid samtidig størsteparten af dette områdes sommerhusbyer i forstadsdannelsen, har bogen desuden påvist, at det først blev sent, at byudviklingsplanlægningen nåede ud til metropolens yderste dele. I lyset af Principskitsen og Første Etapeplanen og efterhånden som den byvækst, som hovedstadsmetropolen gerererede, begyndte at brede sig dybere ind i Frederiksborg og Roskilde amtskommuners udvidedes ganske vist de eksisterende byudviklingsområder omkring købstæderne i købstadsringen, ligesom der i midten af 60 'erne udlagdes to nye byudviklingsområder for den nordligste del af Nordsjælland og Hornsherreds nordlige del. Ikke des to mindre blev det først sent, at byudviklingsplanerne kom til at dække udkanten af disse byudviklingsområder.

Da de samtidig ikke omfattede den sydlige del af Hornsherred, kom størstedelen af den første efterkrigstids voldsomme spredning af sommerhusbyer i hovedstadsmetropolens ydre dele dermed til at stå uden for den regionale inddæmning af den byspredning i det åbne land, som byudviklingsplanlægningen ellers muliggjorde inden for byudviklingsområderne. Planlægningen af anvendelsen af det åbne land og dermed bebyggelser i samme, herunder sommerhusbyer, der endnu ikke var omfattet af en byudviklingsplan eller stod uden for byudviklingsområderne blev således alene overladt til fredningsmyndighederne.

\section{Regionale plandispositioner $\mathbf{i}$ det åbne land}

Med 50'ernes mere omfattede bymæssige bebyggelser og somerhusbydannelser i de ydre dele af hovedstadsmetropolen og i oplande til andre store byer, der lå uden for byudviklingsområderne, kom denne regionale byspredning så meget i konflikt med velfærdsstatens kultur- fritidspolitiske søjle, at planlægning af anvendelse og beskyttelse af det åbne land for alvor kom i spil. 
Udvidede planmuligheder og- retningslinjer

Med henblik på udarbejdelse af flere og arealmæssigt mere omfattende fredningsplaner nedsatte Statsministeriet i 1960, og fra 1961 Kulturministeriet, efter en ændring af naturfredningsloven i 59, fredningsplanudvalg rundt om i landet. Fra samme àr skulle amtskommunerne efter den nye landsbyggelov desuden i kommuner, der ikke var omfattet af frednings- og byudviklingsplaner godkende udstykningssager og- planer i det åbne land, og i sognekommuner, der ikke var byplan- og bygningsvedtægtspligtige tillige godkende alle bebyggelser. Beføjelser, der året efter, med en yderlige ændring i naturfredningsloven, suppleredes med, at nye bygninger i det åbne land, der lå uden for kommende fredningsplaners områder eller et byudviklingsområde, kun måtte opføres efter det stedlige fredningsplanudvalgs tilladelse.

En helgardering mod planløst byggeri i det åbne land, som bogen påviser, ændrede den regionale planstruktur således, at den regionale planlægning de facto blev delt mellem byudviklingsudvalg for den bymæssige udvikling i større byer og disses oplande og fredningsplanudvalg for områder uden for byudviklingsområderne og dermed for hovedparten af det åbne land. En forandret planstruktur, der stillede de forskellige regionale planmyndigheder forskelligt i forhold til de opgaver, disse skulle varetage i bymæssige områder og i det åbne land, såfremt der for et givet regionalt område ikke, som for hovedstadsmetropolens område, forelå en samlet egnsplan at få ud fra. I det lys nedsattes i 1961 et statsligt centralt Landsplanudvalg, der allerede året efter fremlagde en zoneplan for hele landet, hvori dette med en række overordnede retningslinjer opdeltes i: By- og industriudviklingsområder og interesseområder for samme, rene landbrugsområder samt vidstrakte interesseområder for sommerhusbebyggelse og fredning; i hovedstadsmetropolen størsteparten af dens ydre åbne land.

Da 1962-zoneplanen opfordrede til, at kommuner, byudviklingsudvalg og i særlig grad fredningsplanudvalg sporede planarbejdet i retning af de meget løselige retningslinjer, som denne omfattede, udarbejde Kulturministeriet en landsomfattende rammeplan, der på grundlag af 1962-zonenplanen udstak nærmere retningslinjer for det regionale fredningsplanarbejde. Retningslinjer, der i lighed med zoneplanen, tydeligvis afspejlede modsætningen mellem velfærdsstatens almene interessevaretagelse på kultur- og fritidsområdet og individuelle fritids- og friluftsinteresser.

Kulturministeriet lagde således op til en landsdækkende koncentrisk zonering af det åbne land baseret på en optrapning af fredningsinteresserne udgående fra byområder, 1962-zoneplanens by- og industriudviklingsområder og interesseområder for samme, over almindelige ubebyggede landzoneområder og sommerhusbyområder til det, som betegnedes som naturparker af betydning for: Hele befolkningens æstetiske oplevelse, fysiske rekreation og forståelse af landskabets indhold og udvikling samt naturvidenskabelig og kulturhistorisk bearbejdelse og belysning af det danske landskab sammensætning og udvikling. I den sammenhæng rammesatte Kulturministeriet sommerhusbyområderne planmæssigt som en art byudviklingsområde, der fra det åbne land dannede overgang til naturparkerne, og hvor sommerhusbeboeren skulle kunne opnå en individuel nydelse af siden ege grund uden, at det skete på bekostning af de almene samfundsinteresser, der knyttede sig til naturparkerne.

\section{Fredningsplanudvalgets planarbejde}

Ud over at udvide 1940-fredninsgplanen med de områder på hovedstadsmetropolens Vest- og Nordvestegn, der indgik i Den grønne betænkning og med nye områder, som ønskedes fredningsplansbelagt af Søllerød, Birkerød og Farum kommuner for at sikre disses karakter af velhavernaturforstæder, har bogen påvist, at det udvidede fredningsplanudvalg omfattende hovedstadsmetropolens tre amtskommuner, op gennem 60'erne længere ude i metropolens åbne land udpegede en række mulige fredningsområder. Heraf kom nogle til at indgå i konkrete godkendte fredningsplaner, mens andre blev optaget i fredningsplanforslag, der 
efterfølgende dannede grundlag for betydelige fredninger og andre offentlige rekreative arealerhvervelser.

For at hindre, at sommerhusbybæltet ved Kattegat afspærrede yderligere dele af kysten, og trængte for langt ind i baglandet, der ikke var underlagt en byudviklingsplan, udarbejde fredningsplanudvalget med dette sigte og fik efterfølgende godkendt en fredningsplan, der omfattede hele kystlinjen og et bredt bælte ind i det bagved liggende landområde. For at sikre adgangen til strandene og naturoplevelser for almenheden lagde planen op til dannelsen af grønne kiler fra oplandet og ned mod kystlinjen. I forhold til denne fredningsplan frededes eller erhverves til offentlig eje efterfølgende de tilbageværende friarealer ved og grønne kiler i kystområdet, områder længere inde i landet og omkring og mellem Arresø og Esrum Sø. Et omfattende fredningsplanarbejde, der op gennem 60 ' erne og i de sidste efterkrigstid hindrede en forsat vilkårlig spredning af Kattegatkystens sommerhusbybælte, og for almenheden sikrede betydelige kyst- og landskabsområder af rekreativ og natur- og kulturhistorisk værdi.

Ud over denne betydelige landvinding udarbejde fredningsplanudvalget forslag til fredningsplaner for Hornsherred og Roskilde Fjords østlige kystområde og for de syd for Hornsherred liggende vidstrakte skovrige område på Midtsjælland. De to skitserede fredningsplanområder lå enten helt uden for hovedstadsmetropolens byudviklingsmåder eller blev sent en del af disse, men opnåede ikke Overfredningsnævnets godkendelse. Det på trods kom fredningsplanforslagne til at danne grundlag for række store sammenhængende fredninger og offentlige rekreative arealerhvervelser. Dispositioner, der dels førte til, at en betydelig del af sommerhusbyerne i Hornsherred og ved nord- og østsiden af Roskilde Fjord fik form af mere afgrænsede byområder, og ikke kom til at flyde samme som ved Kattegatkysten, dels for samfundet som helhed sikrede meget betydelige og højklassede landskaber både ved Roskile Fjord, i Hornsherred og syd for halvøens rod i retning mod det nordlige Stevns. Områder, som tillige stilledes til rådighed til offentlighedens friluftsliv.

Ved siden af fredningsplanarbejdet og gennemførelse af konkrete fredninger og arealerhvervelser har bogen påvist, at det blev fredningsplanudvalget, der i samarbejde med de stedlige byudviklingsvalg de facto meddelte tilladelse til udlæg af sommerhusbebyggelse i de dele af hovedstadsmetropolens ydre opland, som var omfattet af en byudviklingsplan og dennes yderzone. Herudover havde metropolens fredningsplanudvalg, som anført, fået mulighed for at dæmme op for de værste vildskud i det àbne land, idet nye bygninger, herunder sommerhus, her kun kunne opføres efter udvalgets tilladelse.

I allerede udlagte sommerhusbyer gav fredningsplanudvalget dog i hovedsagen de ønskede tilladelser. Tilsvarende var amtskommunerne tilbøjelig til at undgå forbudsnedlæggelse i forhold til sommerhusbyggeri på de sagsområder, hvor det havde mulighed for det, og godkendte som helhed tillige sommerhusudstykninger, når kommunerne samstemmigt med stedlige bønder og andre udstykkere anmodede om det. Fredningsplanudvalget satte sig dog ofte i mod, hvis der udstykkedes eller bebyggedes på arealer på eller op til udsigtspunkter eller kommende bebyggelse ville spærre udsynet fra sådanne. Særlig restriktiv var udvalget ved opførelse af enkeltstående eller flere sommerhusbygninger i det åbne land, idet disse senere ville kunne give anledning til dannelsen af egentlig sommerhusbyer.

Selv om disse helgarderinger i forhold til mere omfattende byggeri i det åbne land ikke blev så fuldstændige, som landsbyggeloven og ændringerne af naturfredningslovgivningen havde lagt op til, har bogen påvist, at 60 'erne repræsenterede betydelige rekreative og naturbeskyttende landvindinger i hovedstadsmetropolens ydre del, hvorved der samtidig kunne gennemføres den delvise afgrænsning af sommerhusbyernes videre spredning, som tidens $\varnothing$ vrige regionale plandispositioner og lokale byplan- og bygningsvedtægter ikke muliggjorde. Selv om denne afgræsning ikke omfattede samtlige af hovedstadsmetropolens sommerhusbyer, og inddæmningen af sommerhusspredningen dermed ikke blev fuldstændig, tegner der sig i hvert fald for planlægningen af hovedstadsmetropolens åbne land et mere nuanceret billede end det, 
landsskabsarkitekten Jørgen Primdahl i 2011 giver i sit bidrag til Byplanhistorisk Skriftserie, jf. Indledningens Kapitel1. Her anfører han, at Danmark i den første efterkrigstid havde Nordvesteuropas dårligste plansystem, hvilket efter Primdals vurdering bl.a. manifesterede sig ved, at størstedelen af kysterne blev fyldt op med sommerhuse efter princippet om flest mulige byggegrunde pr. udstykning.

En synspunkt Primdal med en vis rette kan se understøttet af den kortlægning Landsplanudvalget i gennemførte i 1966, og som dokumenterede, at alene $200 \mathrm{~km}$ af de 1.700 km lange lystrækninger på Sælland og Møn var egnet til intensiv badning og rekreativt friluftsophold, og at mere end halvdelen af disse $200 \mathrm{~km}$ var belagt med sommerhusbyer eller reserveret til udvidelse af eksisterende eller udlæg af nye sommerhusbyer.

En chokerende konstatering, der efterfølgende førte til et tilsvarende kortlægningsarbejde omfattende landet, og mundede ud i mere vidtgående planmaterialer om arealanvendelsen af det åbne land i form af: En grøn zoneplan fra 1969 med udpegning af fredningsmæssige og rekreative interesseområder, der rummede mulighed for rekreative oplevelser i et langt større antal naturområder end dem, der indgik i fredningsplanerne. Og siden i 1974 i en landsdækkende rapport om arealplanlægning, der, udover planmæssige og prioriterede pejlemærker for byudvikling, i det åbne land udstak særlige interesseområder af landskabelig, videnskabelig og rekreativ betydning. Interesseområder, hvor eksisterende og kommende sommerhusbyer indgik, og som blev et afgørende grundlag for den kommende fredningsdelen i den regionsplanlægning, som Hovedstadsrådet gennemførte i den sidste efterkrigstid, samtidig med at det håndterede hovedstadsmetropolens øvrige regionale udfordringer. Herunder de $\varnothing v$ rige regionsudfordringer, der fulgte af metropolens sommerhusbydannelser, og som ikke var blevet håndteret i den første efterkrigstid. 


\section{Noter:}

Forkortelser:

RDT: Rigsdagstidende:

FT: Folketingstidende

TA: Tillæg A

TB: Tillæg $B$

TC: Tillæg $C$

FF: Folketingets forhandlinger

LF: Landstingets forhandlinger

Lovt.: Lovtidende

BRF: Københavns borgerrepræsentanters forhandlinger

KBF: Frederiksberg Kommunalbestyrelses forhandlinger

B: Årsberetninger, Frederiksberg Kommune

\footnotetext{
${ }^{1}$ Bro: Hovedstadsmetropolen - den danske byregion, 2020, s. 576-578 og 684-687.

2 Bro: Hovedstadsmetropolen - den danske byregion, 2020, s. 685.

${ }^{3}$ Statistisk Årbog for København, Frederiksberg m.m., 1976, s. 321.

${ }^{4}$ Levevilkår i Danmark 1976, s. 240.

5 Johansen: Dansk økonomisk statistik 1914-1980, Danmarks historie, bd. 9, 1985, s. 89 og 91.

${ }^{6}$ Sved Aage Hansen: Økonomisk vækst i Danmark, 1914-1975, bd. 2, 1977, s. 124-225.

7 Johansen: Dansk økonomisk statistik 1914-1980, 1985, s. 99.

${ }^{8}$ Antallet af sommerhusbyer i Hornsherred suppleredes i de sidste efterkrigstid med ydrelige to mindre sommerhusbyer.
}

${ }^{9}$ Afsnittet bygger på de delregionale analyser, der gennemføres i Kapitel 3-6 på basis af det i APPENDIX VI angivne kildemateriale.

${ }^{10}$ For de enkelte købere uden kendskab til de lokale forhold ofte med den personlige ubehagelige overraskelse ved at konstatere at den erhvervede sommerhusgrund i vinter- og forårsmånederne blev oversvømmet og dermed var uanvendelig. Ovenstående afsnit bygger i øvrigt på de delregionale analyser, der gennemføres i Kapitel 4-7 på basis af det i APPENDIX VII angivne kildemateriale.

${ }^{11}$ Selv om både mellem- og efterkrigstidens sommerhuse næste udelukkende opførtes af enkelthusstande som private fritidsboliger, forekom der $\mathrm{i}$ et minimalt omfang alternative ejerformer. Allerede i 1939 havde Motorcykellejrklubben Ariel opkøbt en større grund tæt ved Isejordskysten, hvor den i den første del af 50 'erne fik mulighed for at opføre otte mindre weekendhytter. Klubbens initiativ udvidedes yderligere, da den i 1947 erhvervede en langt større strandgrund ved Roskilde Fjord ved det, der senere skulle blive til sommerhusbyen Store Havelse Strand. Fra 1963 til 1964 opstillede medlemmerne i en mindre klynge 17 mindre sommerhuse med 2-3 værelser på grunden, der ud over en fællesbygning med toiletter omfattede et betydeligt fællesareal ned mod fjorden Appendix VII: Dele om Hornsherred og Roskilde Fjords østside.

12 Arbejderklassens andel af beskæftigede udviste i den første efterkrigstid en faldende tendens som følge af både kapitalkoncentrationen og automatiseringen i industrien.

${ }^{13}$ Den første efterkrigstid førte til en øget koncentration i den private sektor, hvorved gruppen af mindre selvstændige kom til at udgøre en mindre andel af de erhvervsbeskæftigede.

${ }^{14}$ I den første efterkrigstid øgedes andelen af beskæftigede privat og offentligt ansatte funktionærer på forskellige niveauer markant som følge af den offentlige sektors vækst, større administrative enheder i produktionsvirksomheder og fremvækst af serviceproducerende erhverv.

15 Johansen: Dansk økonomisk statistik 1914-1980, 1985, s. 99.

${ }^{16}$ Levevilkår i Danmark, 1976, s. 240-241.

17 Johansen: Dansk økonomisk statistik 1914-1980, 1985, s. 88-92 og 97-100. Bro: Metropoludfordringer, 2019, s. 50 og 124-129.

${ }^{18}$ Afsnittet bygger på de delregionale analyser, der gennemføres i Kapitel 3-6 på basis af det i APPENDIX VI angivne kildemateriale.

${ }^{19}$ Afsnittet bygger på de delregionale analyser, der gennemføres i Kapitel 3-6 på basis af det i APPENDIX VI angivne kildemateriale.

${ }^{20}$ Afsnittet bygger på de delregionale analyser, der gennemføres i Kapitel 3-6 på basis af det i APPENDIX VI angivne kildemateriale.

${ }^{21}$ Om Hundested: Se nærmere i efterfølgende Kapitel 5.

22 Se noter til APPENDIX VII: Kattegatkysten. J.P. Trap: Danmark, 4. udg., bd. II, 1920, s. 105-106 og 109-110. J.P.

Trap. Danmark, 5.udgave, bd. III, 1953, s. 165-170.

${ }_{23}$ Motortrafikvejsstrækningen herfra til øst for Helsingeåbnes først i 1997.

${ }^{24}$ Afsnittet bygger på de kilder, der er angivet under APPENDIX VI.A.

${ }^{25}$ Afsnittet bygger på de kilder, der er angivet under APPENDIX VI.A.

${ }^{26}$ Afsnittet bygger på de kilder, der er angivet under APPENDIX VI.A.

27 Afsnittet bygger på de kilder, der er angivet under APPENDIX VI.A.

${ }^{28}$ Afsnittet bygger på de kilder, der er angivet under APPENDIX VI.A.

${ }^{29}$ Afsnittet bygger på de kilder, der er angivet under APPENDIX VI.A. 
30 J.P. Trap: Danmark, 4. udg., bd. II, 1920, s. 128-132. J.P. Trap. Danmark, 5. udg., bd.III, 1953, s. 199-206.

31 J.P. Trap: Danmark, 4. udg., bd. II, 1920, s. 54-60, 124-127 og 164-165. J.P. Trap. Danmark, 5. udg., bd. III, 1953, s. 81-88, 194-199 og 245-247. https://danmarkshistorien.dk/leksikon-og-kilder/vis/materiale/frederiksvaerk/ 32 J.P. Trap: Danmark, 4. udg., bd. II, 1920, s. 60-64 og 168-170, 333-336 og 341-345. J.P. Trap. Danmark, 5. udg., bd. III, 1953, s.90-95 og 251-254. J.P. Trap: Danmark, 5, udg., bd. II,3, 1960, s. 1106-1110 og 1122-1131. https://www.frederikssund.dk/service/Organisation/Fakta/Historie .

https://kulturarv.roskilde.dk/iyllinge-kulturarv/noget-om-jyllinges-bygninger-og-steder http://www.vestbojyllinge.dk/historie.htm http://www.vestbo-jyllinge.dk/travetur.htm https://kulturarv.roskilde.dk/jyllingekulturarv/fortaellinger-jyllinge/brugsens-historie

${ }_{33}$ Afsnittet bygger på de kilder, der er angivet under APPENDIX VI.B.

${ }^{34}$ Afsnittet bygger på de kilder, der er angivet under APPENDIX VI.B

${ }^{35}$ Afsnittet bygger på de kilder, der er angivet under APPENDIX VI.B.

${ }^{36}$ Afsnittet bygger på de kilder, der er angivet under APPENDIX VI.B.

${ }^{37}$ Afsnittet bygger på de kilder, der er angivet under APPENDIX VI.B.

${ }^{38}$ Afsnittet bygger på de kilder, der er angivet under APPENDIX VI.B.

${ }^{39}$ Den midtsjællandske midtbane indgik allerede i de store jernbanelove fra tiden lige efter århundredskiftet og var tænkt som statstransitbane uden om hovedstaden fra jernbanefærgeforbindelsen til Sverige ved Helsingør, ad den allerede i 1860 'erne anlagte del af Nordbanen mellem Helsingør og Hillerød og som en nyanlagt bane fra Hillerød til Frederikssund, ned gennem Hornsherred til Hvalsø og derfra til Ringsted og herfra til Næstved. Herfra ville der ad den i 1870 anlagte Sydbane, Roskilde-Køge-Næstved-Gedser, være forbindelse til færgeforbindelsen til kontinentet. Arbejderne blev dog først påbegyndt under første verdenskrig. I 1921 stod den dobbeltsporede strækning NæstvedRingsted færdig, 1924 og 1925 fugte strækningerne Havls $\varnothing$-Frederikssund og Hvals $\varnothing$-Ringsted. Op gennem den sidste del af 20'erne og den første del af 30 'erne er banestrækningen mellem Frederikssund og Hillerød i det væsentligste færdigbygget. På strækningen gennem Hornsherred skulle den sjællandske midtbane samtidig fungere som lokalbane. Da en stadig større del af den svenske godstrafik overføres med jernbanefærgerne mellem Trelleborg og kontinentet, der var modstad i hovedstaden mod at transittrafikken gik uden om denne, og lokaltrafikken blev mindre end forventet som følge af den stadig mere udbredte private rutebilstrafik, nedlagdes banestrækningen FrederikssundRingsted.

40 J.P. Trap: Danmark, 4. udgave, bd. II, 1920, s. 178-200 og s. 357-367. J.P. Trap: Danmark, 5. udg., bd. II,3, 1960, s. 1152-1169. J.P. Trap: Danmark, 5. udg., 1953, s. 266-296. https://skibby.dk/historie/

http://www.dedanskesland.dk/i hornsherred-45.html http://evp.dk/index.php?page=den-sjallandske-midtbanemidtsjallandsbanen

${ }^{41}$ Afsnittet bygger på de kilder, der henvises til APPENDIX VI.C.

${ }^{42}$ Afsnittet bygger på de kilder, der henvises til APPENDIX VI.C.

${ }^{43}$ Afsnittet bygger på de kilder, der henvises til APPENDIX VI.C.

${ }^{44}$ Afsnittet bygger på de kilder, der henvises til APPENDIX VI.C.

${ }^{45}$ Afsnittet bygger på de kilder, der henvises til APPENDIX VI.C.

${ }^{46}$ Afsnittet bygger på de kilder, der henvises til APPENDIX VI.C.

${ }^{47}$ Afsnittet bygger på de kilder, der henvises til APPENDIX VI.D.

${ }^{48}$ Afsnittet bygger på de kilder, der henvises til APPENDIX VI.D

${ }^{49}$ Afsnittet bygger på de kilder, der henvises til APPENDIX VI.D.

50 Afsnittet bygger på de kilder, der henvises til APPENDIX VI.D.

${ }^{51}$ Afsnittet bygger på de kilder, der henvises til APPENDIX VI.D.

52 Afsnittet bygger på de kilder, der henvises til APPENDIX VI.D.

${ }^{53}$ Afsnittet bygger på de kilder, der henvises til APPENDIX VI.D.

${ }_{54}$ Afsnittet bygger på de kilder, der henvises til APPENDIX VI.D.

55 Afsnittet bygger på de kilder, der henvises til APPENDIX VI.D.

${ }^{56}$ Da disse udfordringer var størst i hovedstadsmetropolen og med byregions stadig større udbredelse også på det $ø$ vrige Sjælland med omliggende øer gennemførte Landsplanudvalget en kortlægning af mulighederne for badning og rekreative ophold ved og sommerhusbyernes udbredelse og mulige udvikling omkring kysterne i disse dele af landet. Kortlægningen, hvis resultat fremlagdes i 1966, påviste at kun $200 \mathrm{~km}$ ud af $1.700 \mathrm{~km}$ kyststrækning i denne del af landet var egnet til intensiv badning og rekreativt friluftsophold, og at mere end halvdelen af disse $200 \mathrm{~km}$ belagt med sommerhusbyer eller reserveret til udvidelse af eller udlæg af sommerhusbyer.

57 Kildemateriale som anført under ovenstående kapitel 4-7 samt Fritidsområder og sommerhusbebyggelse, 1970, s. 77-85. Betænkning om helårsbeboelse i sommerhusområder. Afgivet af det af Miljøministeriet den 12. september 1980 nedsatte udvalg vedrørende sommerhusloven §§ 7 og 7a, 1981, s., 12-14 og 18.

${ }^{58}$ Rigsarkivet og hjælpemidlerne til dets benyttelse II, bd.1, (red. Wilhelm von Rosen), s. 181-185. Dansk Biografisk Leksikon bd. II (red Sv. Cedergreen Bech), 1979, s. 341-342.

${ }^{59}$ Biblioteksbetænkningen, afgivet af bibliotekskommissionen, 1979, s. 15-16.

60 En kulturpolitisk redegørelse, afgivet af Ministeriet for kulturelle anledning, 1969, s.69-222. Biblioteksbetænkningen, afgivet af bibliotekskommissionen, 1979, s. 14-22.

61 Bro: Hovedstadsmetropolen - den danske byregion, 2020, s. 608-609.

62 Indtil 1970-kommunlareformen dækkedes amtskommunernes indtægter med halvdelen ved udskrivning af grundskyld på op til 14 promille, mens den anden halvdel blev pålignet sognekommunerne med havdelen i forhold til de skattepligtige grundværdier og halvdelen i forhold til de skattepligtige indkomster i kommunerne.

${ }^{63}$ Hovedstadskommissionens flertalsindstilling lagde op til indlemmelse af de omkring København liggende forstadskommuner i Københavns Kommune, gennem betydelige indlemmelser dannelse af fem store forstadskommuner samt et forbund af forstadskommuner til løsning af disses amtskommunale opgaver. Både kommissionens flertal og dens mange mindretal var enige om, at der skulle etableres et regionalkommunalt organ, et 
hovedstadsråd, over hovedstadsmetropolens købstads- og amtskommunale niveau til varetagelse af den samlede byregions opgaver.

${ }^{64}$ Fritidsområder og sommerhusbebyggelse, 1970, s. 77-85. Bro: Hovedstadsmetropolen - den danske byregion, 2020, s. 804-805.

${ }^{65}$ Hovedstadsmetropolens og landets $ø$ vrige store byers vækst og funktionelt hensigtsmæssige opbygning blev set som en af velfærdsstatens, i øvrigt flere, redskaber til at sikre den økonomiske vækst, der ikke blot gennem velfærdssystemets fordelingsvirkninger fortsat skulle udjævne klassebestemte økonomiske og sociale forskelle, som markedet selvsagt ikke havde til formål at gøre, men også via plandispositioner skulle udligne markedsøkonomisk bestemte regionaløkonomiske forskelle, idet væksten fra de store byer skulle brede sig ud i alle dele af landet. Denne, på den såkaldte vækstcenterteori baserede, vækstfilosofi gik i gennem i samtlige af den første efterkrigstids egnsplanskitser.

${ }^{66}$ Bro: Hovedstadsmetropolen - den danske byregion, 2020, s. 810-811.

67 Skitseforslag til Egnsplan for StorKøbenhavn udarbejdet 1947 af Egnsplankontoret, 1948, [Fingerplanen], s. 50.

${ }^{68}$ Fingerplanen, 1948 , s. $33-35$ og 50.

69 Bro: Hovedstadsmetropolen - den danske byregion, 2020, s. 810-811.

70 Betænkning om partiel byudviklingsplan nr. 2 for Københavns-egnens byudviklingsområde, 1951, s. 10-36. Betænkning vedrørende partiel byudviklingsplan nr. 3 for Københavns-egnens byudviklingsområde, 1953, s. 8-26. Betænkning om Naturfredning I, afgivet af Ministeriet for kulturelle anliggender under 23. november 1961 nedsatte Naturfredningskommission, 1967, s. 56. Notat om Storkøbenhavns planlægning, af 30.5.1960, j.nr. 33-114-60, Boligministeriets 2. kontor (Rigsarkivet)

71 Bro: Hovedstadsmetropolen - den danske byregion, 2020, s. 812-814.

72 Principskitse til egnsplan for byudviklingen indtil 1980 i Københavns, Frederiksborg og Roskilde amter, Egnsplansekretariatet for Storkøbenhavn, 1960, s. 2-47, j.nr. 145.4., 1937-1970 og Hovedstrukturen, Egnsplansekretariatet for Storkøbenhavn, 1961, S. 3-9, 14-15 og 34-39, Sekretariatet for Den tekniske Forvaltning, [Frederiksberg Stadsarkiv, A 1202].

${ }^{73}$ I den ledsagende betænkning bag denne reviderede byudviklingsplan skitserede byudviklingsudvalget nogle regionalt baserede retningslinjer for de to egnes sidste udbygning. På grundlag af udvalgets tidligere yderzoneinddragelse og ved forslag til kommende bebyggelse af de nyudlagte mellemzoner blev der lagt op til større industrikvarterer ved Avedøre Holme, i den vestlige del af Rødovre, øst, nord og syd for Glostrup, mellem Albertslund og Glostrup samt nord og vest for Tåstrup, ved Islev, syd for Herlev, mellem Skovlunde og Ballerup og vest og nord for sidstnævnte. Herudover skulle den øvrige bebyggelse følge de hidtil anlagte og i praksis anvendt principper $\mathrm{i}$ form af boligbyggeri med stor udnyttelsesgrad, etagehuse eller tæet-lavt byggeri, i områder omkring S-banestationerne og boligbebyggelser med lille udnyttelsesgrad, kvarterer med parcel- og rækkehuse og industrikvarter, i de enkelte forstadsbyers udkanter.

74 Det blev da også i denne del af Nordegnen, hvor byudviklingsudvalget i betænkningen bag den nye byudviklingsplan så muligheder for, at både Fingerplanens og Første Etapeplans stationsnærhedsprincip kunne slå igennem i form af afgrænsede byenheder $\mathrm{i}$ et radialt forstadsbånd langs den yderste del af Farum-banen nordvest for Bagsværd-bydelen i Gladsaxe Kommune.

${ }^{75}$ Med byudviklingsplanernes fastfrysning af de eksisterende forstadsbånds vækst og udlæg af rekreative kiler og andre yderzonebelagte rekreative områder uden sommerhusbebyggelse, blev rammerne lagt for den udbygning af den indre del af hovedstadsmetropolen og af det nord for liggende delbyudviklingsområde, som fandt sted fra i 60 'erne og op gennem den sidste efterkrigstid. Samtidig hermed blev den bebyggelsesmæssige planlægning ud fra et regionalt perspektiv styrket via Køge Bugt-dispositionsplanen, de retningslinjer, der indgik i betænkningerne bag byudviklingsplanerne, og den regionale byplanadministrative koordinationsstruktur, som Byplansnævnets Hovedstadsafdeling med medvirken af Byudviklingsudvalget i Københavns-egnen udgjorde. Regionale byplanrammer af afgørende betydning for den faktiske fordeling af bebyggelsesarter ved udbygningen af hovedstadsmetropolens forstadsbånd.

${ }^{76}$ Betænkning vedrørende partiel byudviklingsplan nr. 4. for Københavns-egnens byudviklingsområde, 1960, s. 9-29. Betænkning vedrørende partiel byudviklingsplan nr. 5. for Københavns-egnens byudviklingsområde, 1961, s. 10-49. Betænkning vedrørende partiel byudviklingsplan nr. 6. for Københavns-egnens byudviklingsområde, 1965, s. 9-61. Betænkning vedrørende partiel byudviklingsplan nr. 7. for Københavns-egnens byudviklingsområde, 1966, s. 15-50. Betænkning vedrørende partiel byudviklingsplan nr. 8. for Københavns-egnens byudviklingsområde, 1967, s. 11-31. Betænkning vedrørende partiel byudviklingsplan nr. 9. for Københavns-egnens byudviklingsområde, 1972, s. 11-32. Svend Illeris: Centraladministration og planlægning 1938-ca 1975, 2013, s 33-35. Holden Andersen: Lidt om fredningsplanlægning, 1994, s. 13-16. Notat om Storkøbenhavns planlægning, af 30.5.1960, j.nr. 33-114-60, Boligministeriets 2. kontor (Rigsarkivet)

${ }^{77}$ Da 1937-fredningsloven med ændringer og stiloven i hovedstadsmetropolen i det ønskede omfang ikke kunne tilvejebringe større områder til strandbadning - og ophold, teltlejre og andre former for mere arealkrævende friluftsliv, havde Statsministeriet allerede i 1942 nedsat det såkaldte Friluftsudvalg. Udvalget fremlagde allerede i 1948 et lovforslag, der gik i samme retning, men som rummede flere myndighedsbeføjelser. Da de borgerlige, og særlig Venstre, ved behandlingen af 1959-naturfredningslovændringen fandt de foreslåede fredningsplaner for vidtgående i forhold til den private ejendomsret og det private initiativ, og dermed landbruget og de øvrige erhverv, gav regeringen, for så vidt som muligt at opnå konsensus i naturfredningslovgivningen, køb på disse mere vidtgående myndighedsbeføjelser, for så vidt angik arealerhvervelse til de nævnte rekreative formål. Rigsdagsbehandlingen af 1959-naturfredningslovændringen: FT, 1958/59, TA, s. 585-590, FF, s. 418-422, 695-712, 2943-2948. Lovt. 471-472. ${ }^{78}$ Også behandlingen af 1961-ændringsloven blev fra Venstres side igen mødt med de sædvanlige tirader om overgreb i forhold til ejendomsretten, idet man ud fra sit sædvanlige hensyn til landbrugets interesser i særlig grad vendte sig mod de nye bestemmelser om beskyttelseslinjer. De konservative udviste ved folketingsbehandlinger på ny den velvillige position i naturfredningsspørgsmål, men også erstatning ved fredningsnævnenes eventuelle manglende 
byggetilladelse. For endnu engang at få de to borgerlige partier til at stille op bag naturfredningslovgivningen, nedsattes beskyttelseslinjen ved søer og vandløb til $150 \mathrm{~m}$, ligesom der ved fredningsnævnenes manglende tilladelse til nybyggeri i det åbne land kunne gives den nuværende jordejer erstatning for provenutab i forhold til eventuelle udstykninger. Men ikke en generel erstatning til andre ejere, idet det befrygtedes, at nogle ville spekulere i opkøb af landbrugsarealer for evt. i forventning om ved planlagt udstykning af arealet at kunne opnå fuld erstatning ved fredningsudvalgets byggeforbud.

${ }^{79}$ FT 1960/61, TA, s. 1143-1151, FF., s. 1687-1890, 2121-2154, 4094-4120, 4424-4438, . Lovt., 1961, $424-427$.

80 Svend Illeris: Centraladministration og planlægning 1938-ca 1975, 2013, s. 43-48 og 57-58.

81 Zoneplan 1961 for Danmark, Landsplanudvalget, 1962, s. 11-12, 21-29. Zoneplankommentarer, Landsplanudvalget, 1964 , s. 42-52.

82 Med Køge Bugt-områdets omdannelse til et af den indre hovedstadsmetropol forstadsbånd kom bugtens

sommerhusbybælte efterhånen til at indgå i båndets villakvarterer. Ud over Kattegatkysten sommehusbybælter forblev det smalle sommerhusbybælte ved Strøby Stand den eneste tilbageværende af denne art. For her at sikre den tilbageværende sidste ubebyggede del af strandlinjen frededes denne allerede i 1947.

$83 \mathrm{https}: / / d o k u m e n t . p l a n d a t a . d k / 20158$ APPROVED 1182153462908.pdf

https://public.filarkiv.dk/Document/Open/2/sag/A0B736DB9A194294AC8852D35C5F72FB?searchSource=0\#pagemod e=thumbs\&view $=$ fitV

${ }^{84}$ https://www2.blst.dk/nfr/00508.00.pdf https://www2.blst.dk/nfr/00336.00.pdf https://www2.blst.dk/nfr/00706.00.pdf https://www2.blst.dk/nfr/00973.00.pdf

${ }^{85}$ https://www2.blst.dk/nfr/01320.00.pdf https://www2.blst.dk/nfr/06330.00.pdf https://www2.blst.dk/nfr/06330.00.pdf

${ }^{86}$ https://www2.blst.dk/nfr/00269.00.pdf

87 https://www2.blst.dk/nfr/00059.00.pd

88 https://www2.blst.dk/nfr/00116.00.pdf https://www2.blst.dk/nfr/00116.00.pdf

89 https://www2.blst.dk/nfr/00376.00.pdf $\mathrm{https://www2.blst.dk/nfr/00376.00.pdf}$

90 https://www2.blst.dk/nfr/00765.00.pdf

91 https://www2.blst.dk/nfr/00105.00.pdf

92 https://www2.blst.dk/nfr/00053.00.pdf

93 https://www2.blst.dk/nfr/01110.00.pdf

94 https://www2.blst.dk/nfr/02808.00.pdf

95 https://www2.blst.dk/nfr/02808.00.pdf https://www2.blst.dk/nfr/02808.00.pdf

96 https://www2.blst.dk/nfr/01796.00.pdf

97 https://www2.blst.dk/nfr/00604.00.pdf

98 https://www2.blst.dk/nfr/01320.00.pdf https://www2.blst.dk/nfr/06330.00.pdf

https://www2.blst.dk/nfr/06330.00.pdf

99 https://www2.blst.dk/nfr/01796.00.pdf

100 https://www2.blst.dk/nfr/01110.00.pdf

101 https://www2.blst.dk/nfr/02993.00.pdf

102 https://www2.blst.dk/nfr/02808.00.pdf

103 https://www2.blst.dk/nfr/02808.00.pdf https://www2.blst.dk/nfr/02808.00.pdf

104 https://www2.blst.dk/nfr/02895.00.pdf https://www2.blst.dk/nfr/04024.00.pdf https://www2.blst.dk/nfr/04024.00.pdf

105 https://www2.blst.dk/nfr/01830.00.pdf

106 https://www2.blst.dk/nfr/06899.00.pdf

107 https://www2.blst.dk/nfr/07929.00.pdf

108 https://www2.blst.dk/nfr/07829.00.pdf

109 https://www2.blst.dk/nfr/01138.00.pdf https://www2.blst.dk/nfr/00192.00.pdf

110 https://www2.blst.dk/nfr/02064.00.pdf https://www2.blst.dk/nfr/02064.00.pdf https://www2.blst.dk/nfr/01769.00.pdf https://www2.blst.dk/nfr/01126.02.pdf

https://www2.blst.dk/nfr/01126.00.pdf

111 https://www2.blst.dk/nfr/01065.00.pdf

112 https://www2.blst.dk/nfr/02999.00.pdf

113 https://www2.blst.dk/nfr/02798.01.pdf

${ }_{114}$ https://www2.blst.dk/nfr/07778.00.pdf https://www2.blst.dk/nfr/01179.00.pdf

115 https://www2.blst.dk/nfr/07778.00.pdf https://www2.blst.dk/nfr/01179.00.pdf https://www2.blst.dk/nfr/02709.01.pdf https://www2.blst.dk/nfr/02702.01.pdf

116 https://www. fredninger.dk/fredning/ramloese-fredninger/

117 https://www2.blst.dk/nfr/00969.00.pdf https://www2.blst.dk/nfr/03166.00.pdf https://www2.blst.dk/nfr/02996.00.pdf

118 https://www2.blst.dk/nfr/07891.00.pdf

119 https://www2.blst.dk/nfr/07891.00.pdf

120 https://www2.blst.dk/nfr/00163.01.pdf

121 https://www2.blst.dk/nfr/01220.00.pdf https://www2.blst.dk/nfr/01220.00.pdf

https://www2.blst.dk/nfr/00493.00.pdf

122 https://www2.blst.dk/nfr/06066.00.pdf

123 https://www2.blst.dk/nfr/05411.00.pdf

124 https://www2.blst.dk/nfr/04529.00.pdf https://www2.blst.dk/nfr/05237.00.pdf

125 https://www2.blst.dk/nfr/00163.01.pdf

$126 \frac{\text { https://www2.blst.dk/nfr/00616.01.pdf }}{\text { htw }}$ 
127 https://www2.blst.dk/nfr/05535.00.pdf

128 https://www2.blst.dk/nfr/00616.01.pdf https://www2.blst.dk/nfr/05825.00.pdf

https://www2.blst.dk/nfr/00768.00.pdf

129 https://www2.blst.dk/nfr/04231.00.pdf

130 https://www2.blst.dk/nfr/08113.00.pdf

131 https://www2.blst.dk/nfr/07925.00.pdf

132 https://www2.blst.dk/nfr/08005.00.pd

133 https://www2.blst.dk/nfr/00270.00.pdf https://www2.blst.dk/nfr/00512.00.pdf

134 https://www2.blst.dk/nfr/02030.00.pdf

135 https://www2.blst.dk/nfr/02808.00.pdf

136 Ud over henvisningerne i ovenstående noter, bygger dette afsnit på det kildemateriale, der henvises til i tabel

III.47.

137 De dele området, der lå nærmest sommerhusbyen udlagdes efter en samlet plan derimod til sommerhusbebyggelse med kommunalt udlagt vej- og vandforsyningsanlæg. https://www2.blst.dk/nfr/01624.01.pdf

138 http://forsvaret.dk/JPL/Pages/default3.aspx https://naturstyrelsen.dk/media/nst/66893/JaegersprisPlan.pdf

139 https://www2.blst.dk/nfr/05595.00.pdf https://www2.blst.dk/nfr/02401.00.pdf https://www2.blst.dk/nfr/00691.00.pdf https://www2.blst.dk/nfr/04425.00.pdf

140 https://www2.blst.dk/nfr/07886.00.pdf https://www2.blst.dk/nfr/02314.03.pdf https://www2.blst.dk/nfr/02314.02.pdf https://www2.blst.dk/nfr/05876.00.pdf https://www2.blst.dk/nfr/02314.04.pdf

141 https://www2.blst.dk/nfr/01049.00.pdf https://www2.blst.dk/nfr/01049.01.pdf

https://www2.blst.dk/nfr/02711.00.pdf

142 https://www2.blst.dk/nfr/07897.00.pdf

143 https://www2.blst.dk/nfr/02483.00.pdf

144 https://www2.blst.dk/nfr/01182.00.pdf

145 https://www2.blst.dk/nfr/02190.00.pdf

146 https://www2.blst.dk/nfr/07730.00.pdf

147 https://www2.blst.dk/nfr/02753.00.pdf https://www2.blst.dk/nfr/01107.00.pdf

148 https://www2.blst.dk/nfr/00027.00.pdf $\frac{\text { https://www2.blst.dk/nfr/00839.00.pdf }}{\text { ht }}$

https://www.fredninger.dk/fredning/graevlingehoej/ https://www2.blst.dk/nfr/04114.00.pdf

149 https://www2.blst.dk/nfr/07895.00.pdf

150 https://www2.blst.dk/nfr/00810.00.pdf

https://naturstyrelsen.dk/media/nst/Attachments/DekommissioneringRis\%C3\%B8snukleareanl\%C3\%A6g.pdf s. 3637.

https://kommuneplan2016.roskilde.dk/sites/default/files/kommuneplan/kp16 risoeaagerup byudviklingsstrategi ende $\underline{\text { liq.pdf }}$

${ }_{151}$ https://www2.blst.dk/nfr/02820.00.pdf https://www2.blst.dk/nfr/06224.00.pdf https://www2.blst.dk/nfr/05446.00.pdf https://www2.blst.dk/nfr/03624.00.pdf https://www2.blst.dk/nfr/03624.00.pdf https://www2.blst.dk/nfr/04486.00.pdf https://www2.blst.dk/nfr/01771.00.pdf https://www2.blst.dk/nfr/02497.00.pdf https://www2.blst.dk/nfr/07033.00.pdf https://www2.blst.dk/nfr/05295.00.pdf https://www2.blst.dk/nfr/00827.00.pdf https://www2.blst.dk/nfr/00827.01.pdf https://www2.blst.dk/nfr/07921.00.pdf https://www2.blst.dk/nfr/02750.00.pdf https://www2.blst.dk/nfr/07866.00.pdf https://www2.blst.dk/nfr/02384.01.pdf https://www2.blst.dk/nfr/03364.00.pdf https://www2.blst.dk/nfr/00544.00.pdf https://www2.blst.dk/nfr/06224.00.pdf https://www2.blst.dk/nfr/03624.00.pdf https://www2.blst.dk/nfr/07033.00.pdf https://www2.blst.dk/nfr/07921.00.pdf https://www2.blst.dk/nfr/07921.00.pdf https://www2.blst.dk/nfr/07866.00.pdf

https://www2.blst.dk/nfr/00544.00.pdf

152 Udover ovenstående note $62-129$ baseres afsnittet på: KBF, 1954/55, s. 151. 1955/56. s. 65. 1957/58, s. 451. 1962/63, s. 41-42. $1966 / 1967$, s. $192.1968 / 69$, s. $182.1969 / 70$, s. $108.1970 / 71$, s. $170-171,1976 / 76$, s. 212 . J.nr. 776/I, 1928-1969, 776/II, 1959-1977, 776 III, 1978-1984, 776/Fredningssag nr. 49, 1958-1960, nr. 53, 1963-1964, 776/Fredningssag nr. 58, 1963-1966, 776-1, 1946-1970, 776-4, 1963-1978, 776-6, 1973-1975, 776-8, 1975-1983, 776-9, 1975-1980, 776-11, 19811982, Juridisk Direktorat [Frederiksberg Stadsarkiv, A 29]. Betænkning vedrørende partiel byudviklingsplan nr. 6 for Københavns-egnens byudviklingsområde afgivet den 7. oktober 1963 af det af Boligministeriet den 2. juli 1957 nedsatte byudviklingsudvalg for Københavns-egnen, 1965, s. 26-27.14-15. Betænkning vedrørende partiel byudviklingsplan nr. 7 for Københavns-egnens byudviklingsområde afgivet den 30. november 1965 af det af Boligministeriet i oktober 1967 nedsatte byudviklingsudvalg for Københavns-egnen, 1965, s. 26-27. Kildemateriale angivet i APPENDIX VII. Herudover er inddraget: Holden Andersen: Lidt om fredningsplanlægningen og om nogle af de mennesker, jeg mødte hen ad vejen, Byplanhistoriske Noter, nr. 29, 1994, s. 13-42. Holden Andersen var som sekretariatschef i Hovedstadsområdets Fredningsplanudvalg i perioden 1959-1975. Selv om skriftet primært rummer erindringer om de skiftende samarbejdspartnere, som Holden Andersen kom i forbindelse med i sit tjenestelige virke, giver den centralt placerede embedsmand dog en række faktuelle oplysninger om fredningsplanudvalgets arbejde og de fredningsplaner, fredninger og arealerhvervelser, der kom ud af det.

${ }_{153}$ FT 1958/59, TA, s. 2403-2532, TB, s. 1245. Fritidsområder og sommerhusbebyggelse, 1970, s. 52-59 og 77-85. Kilder angivet under APPENDIX VII: Hornsherred.

154 Strandkvalitet og fritidsbebyggelse, Landsplanudvalget 1966, s. 29.

155 Strandkvalitet og fritidsbebyggelse, Landsplanudvalget 1966.

156 Kildemateriale angivet i APPENDIX VI. Bro: Hovedstadsmetropolen - den danske byregion, 2010, s. 701-719 og 783-791. 
157 Kildemateriale angivet i APPENDIX VI. Bro: Hovedstadsmetropolen - den danske byregion, 2010, s. 746-750 og 754-759.

158 Kildemateriale angivet i APPENDIX VI. Bro: Hovedstadsmetropolen - den danske byregion, 2010, s. 729-732 